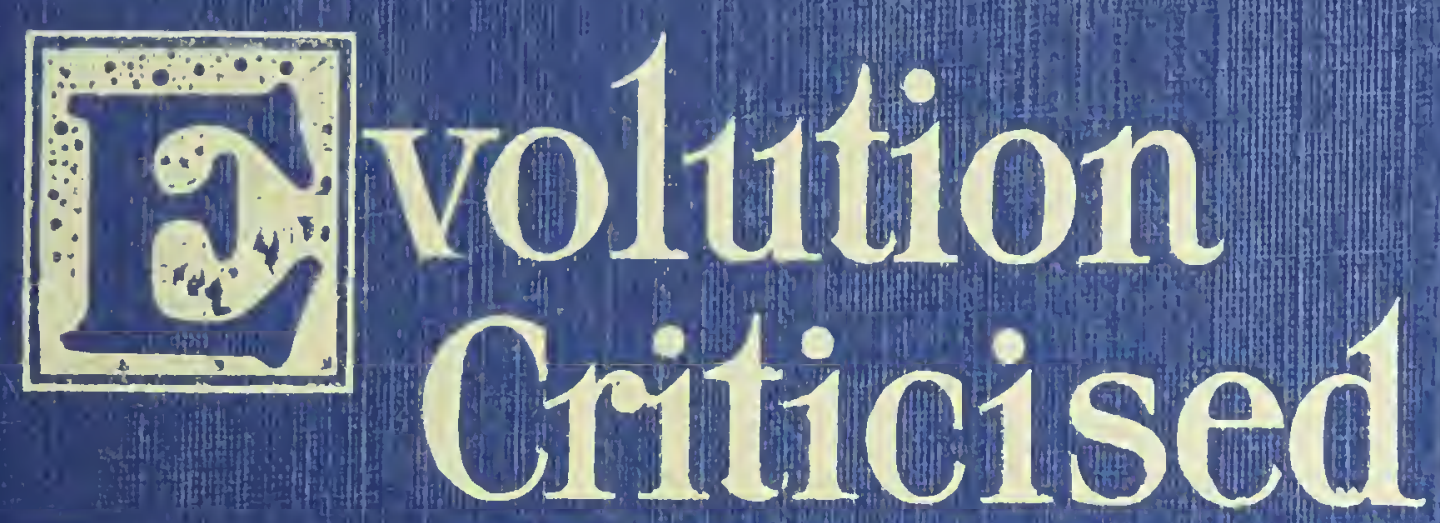

T.B.Bishop 
Library

of the

University of Toronto 
L.C. Creastield.

Curialinas 1945

fmom lenche Ciffford

- Auntie Kalz Lan

THHS BOOK IS THE GIFT FRON THE RANFURLY LIBRARY SEPUCE I8 PARLTON HOUSE TERRACE LONDON, S.W.I.

20 

EVOLUTION CRITICISED. 
Digitized by the Internet Archive in 2020 with funding from University of Toronto 


\title{
EVOLUTION CRITICISED
}

\author{
By \\ T. B. BISHOP,
}

Member of the Council of the Victoria Institute.

OLIPHANTS LTD..

Edinburgh and London.

THE SCRIPTURE UNION OFFICE,

13a, Warwick Lane, London, E.C.4. 



\section{PREFACE.}

IN the current literature of the day the theory of Evolution is treated, almost universally, as if it were one of the most assured facts of science, and it is usually assumed that the doctrine of the descent of mankind from an animal. stem must be accepted as an integral part of Evolution.

The article Evolution in the Encyclopadia Britannica says :-

"The doctrine of evolution has outgrown the trammels of controversy, and has been accepted as a fundamental principle. Writers on biological subjects no longer have to waste space in weighing evolution against this or that philosophical theory or religious tradition; philosophical writers have frankly accepted it, and the supporters of religious tradition have made broad their phylacteries to write on them the new words."

When we examine the many small books on science which are available at the present day for an ordinary student, there is not one that takes any different view.

Then when we review many recent books written in defence of the Bible, we find not a few, even those by some of the most earnest evangelical men, which to a great extent accept what is considered 
to be the verdict of our great scientific experts, and endeavour to show that there may be ways of interpreting the Creation record in Genesis to bring it into accord with the teachings of Science.

The leading biological writers of the day generally pursue their enquiries and speculations as to the origin of life in the world, and as to the origin of inan, without any reference whatever to the fact that there has been a Divine revelation. They do not expressly contradict the Bible; and it is possible to suppose that some of them accept the assurances which so many theologians scem anxious to give them that there are ways of accommodating the language of Scripture to any conclusion at which science may arrive. There are, of course, some evolutionists who are frankly antagonistic to Christianteaching, while others, no doubt, take the position of Professor E. N. MacBride, who says in his Zoology (The People's Books): "The doctrine of evolution, with its consequence, the kinship of man and animals, can throw welcome light on some old moral problems. . Evil is therefore the reversion to a previous state of evolution, and the so-called original wickedness in children is a repetition of an ancestral stage of the race-as truly a larval stage as the tadpole stage of the frog"' (p. 90).

What calls for the most serious consideration is the effect which such teaching must necessarily have upon the young men who are growing up 
anongst us, and specially upon those who will presently be tcachers in our schools and colleges, or who will be called to minister the Word of God in our Churches. While such a view as that of Professor MacBride may not often be openly expressed, is it not in the highest degree probable that sucin opinions are being formed by many young students to-day who see no way of opposing the current teaching of the evolution of the human race irom. an animal ancestry?

There is certainly the view of the late Dr. Alfred Russel Wallace that the evolution applies only to the body of man, and there are some theologians who seem inclined to accept this explanation. But none of the Evolution handbooks now available for students follow Dr. Wallace in this, and, even if they did, Professor MacBride's argument might still be used.

It is very gencrally recognised to-day, by earnest evangelical preachers in all the Churches, that the great hindrance to the acceptance of the Gospel is the lack amongst the people at large of any sense of the guilt of SIN-of any clear realisation of the heinousness of sin in God's sight. Can we wonder at this when we know the lax views of the inspiration of Scripture held by so many of our religious teachers? And must not the theory of man's animal origin have much to do with these erroneous views? If we cannot believe the first chapters of the Bible, 
or if we have to explain away the plain language of those chapters and treat them as myth, or even as parable, are we not admitting doubts as to God's revelation as a whole? If we do not accept the record in Genesis of the Creation of Man, how can we receive that of the Fall of Man? And is it astonishing that there should be a lack of the realisation of the guilt of sin, if we doubt what God has revealed to us as to how sin came into the world?

It is considerations like these that have led me to undertake this work. I have tried to put into it as much information as possible on the subject of Evolution generally, and I have given references in nearly every case to the books in which a student may be able to gain fuller information on any special branch of the subject.

I hope that I have been able to show that the evidence upon which the theory of the descent of man from the animal has been built up has no secure foundation, and that it is contradicted or weakened at almost every point, sometimes by the admissions of the writers themselves who have brought forward the evidence, and sometimes by the opinions of other scientific men quite as eminent. I have also tried to show that the evolution of man from an ancestral ape would involve, at every stage of progress, changes for which no reason could be assigned, and which could only be miraculous.

As regards the theory of Evolution generally, one 
can only say that the whole subject is encompassed with uncertainties. While practically all scientific writers to-day affirm that evolution MuS'T have occurred in the past, they are as hopelessly at variance as ever as to How it has been brought about. I have given a brief sketch of several of the evolution theories propounded by biologists who have found Darwin's Natural Selection theory unsatisfactory, but there are other biologists who find weighty objections against each new theory. That there has been some evolution in Nature we need not deny: it is quite possible that, within certain limits, some species may have been developed from other species, just as what appear like new species of many plants and animals have been produced by the efforts of cultivators and breeders, and it seems probable, when we know what an enormous number of species became extinct in the past ages of the earth's history, that others may have arisen to take their place. But this is altogether a different thing from accepting Evolution as a universal principle of Nature.

I may call special attention here to Wasmann's Modern Biology and the Theory of Evolution, published in English in 1910. The author contends that there are some original species of animals and plants, and very many other species that have been derived from them, and he claims thus to have brought into harmony the theories of Creation and Evolution. 
Fifty years ago I took part in the earliest services of the Children's Special, Service Mission, and in the following year I bccame Honorary Secretary of the Mission, and in 1879 also of the SCRIPTUR: Union for Children and Young People, which arose out of that work. Since the latter year I have edited OUR OWN MAGAZINE, from which articles have becn taken at various times to form Picture Ireaflets for young people in over fifty languages. The Scripture Union Card of portions for daily reading has been issued in more than forty languages, though the war has interrupted some of this work. Then I have for many years edited OUR Boys' Magazrne, which is used by the Sunday Afternoon Bible Classes of the Crusaders' Union, an encouraging movement amongst the boys of our public and private schools. The fact that I have for so long been connected with a widely-spread religious work amongst the young makes everything connected with their growing up into life of the deepest interest to me.

It was in 1892 that, in view of the advance of Biblical criticism, I brought before the late Canon Stuart, the President of the Children's Special Service Mission, a Declaration on the subject of the Inspiration of Holy Scripture, and upon his approval this was adopted by the Committee, and has since appeared, year by year, in our Annual Report. It is in accordance with the principles embodied in 
that Declaration that our work amongst the young has been carried on from the first.

Some letters of mine in reply to attacks on the Inspiration of Scripture have appeared at various times in the Record and other papers. A year or two ago I began a book on the early chapters of Genesis, but I found that I conld not omit the subject of Evolution, and this, I soon saw, claimed a volume to itself.

I should like to acknowledge the help I have obtained through having attended for several years the discussions on scientific subjects at the Victoria Institute. Of course, this book represents my own views, and does not in any way commit any other members of the Council of the Institute.

My most earnest desire and prayer is that this book may be helpful to many who have grown up as members of our SCRIPTURE UNION, and who may now be entering into life, and that it may enable them, notwithstanding all the teaching of the day, to hold fast to the plain meaning of the first chapters of God's Word, and especially to the truth which we learn from the old words: "So God created man in His own image, in the image of God created $\mathrm{He}$ him ; male and female created $\mathrm{H}_{e}$ them."

Febrtary, 1918. 
viii.

\section{The Geological Strata.}

Archatan, Pre-Cambrian, or Eozolc (or Azoic, without life)

(including the Laurentian, named from the river St. Lawrence).

Primary, or Paleozolc (ancient life).

Cambrian.

Lower Silurian, or Ordovician.

Upper Silurian.

Devonian and Old Red Sandstone.

Carboniferous (the coal measures).

Permian.

Secondary, or Mezorc (middle life).

Triassic.

Jurassic (named from the Jura).

Cretaceous (the chalk formations).

Tertiary, or Cainozoic (new life).

Eocene (dawn of recent time).

Oligocene.

Miocene (less recent).

Pliocene (more recent).

Quaternary, or Post-Tertiary.

Pleistocene, or Glacial.

Recent, or Post-Glacial, including :

Palæolithic (old stone): included by some geologists in the Pleistocene.

Neolithic (new stone).

The late Stone Age.

The Bronze Age.

The Iron Age.

These are given in chronological order : in most books on geology they are given in the reverse order, going from the earth's surface downwards. 


\section{EVOLUTION CRITICISED.}

ONE of the most important works that has appeared in recent years on the subject of Evolution is Professor Arthur Keith's The Antiquity of Man. It gives an exhaustive list of the fossil skeletons, skulls, and other human remains, which throw light upon the history of ancient man. Very full illustrations are given in nearly every case, with many comparative diagrams. As in about twenty-five cases the skulls as described have been found since the beginning of the 20th century, this work is absolutely needful for every student who would clearly understand what light has been thrown upon the problem of early man by the most recent discoveries.

The outstanding fact in regard to Professor Keith's book is that, while he is a strong advocate of the descent of man from animal ancestors, he entirely rejects, as "missing links" in the chain, some skulls that have been considered by other biologists as the most important: amongst them, the "Neanderthal" man, and his supposed relatives in Europe. On a full consideration of all the fossil remains of man, he finds that men of quite the modern type lived at the same time as men having the "Neanderthal" characteristics, and in many cases even before them, and he comes to the conclusion that the "Neanderthal" race, and others, must-from some unexplained causes-have died out, leaving no descendants.

"In our first youthful burst of Darwinianism," says Professor Keith (p. 209), "we pictured our evolution as a simple procession of forms leading 
from ape to man. Each age, as it passed, transformed the men of the time one stage nearer to usone more distant from the ape. The true picture is very different. We have to conceive an ancient world in which the family of mankind was broken up into narrow groups or genera, each genus being again divided into a number of species-much as we see in the monkey or ape world of to-day. Then out of that great welter of forms one species became the dominant form, and ultimately the sole surviving one-the species represented by the modern races of mankind."

In the last chapter of his book he says further that he looks on the lately-discovered Piltdown skull (Eoanthropus) as representing an extinct form of inan (p. 505), and from the "genealogical tree of man's ancestry,". given on p. 501, it appears that he treats in the same manner the Java "Pithecanthropus," so that he virtually strikes out from the pedigree of modern man every one of those fossil forms which, from their supposed similarity to the anthropoid apes, have been put forward in many books on Evolution as "missing links" between man and the animal.

The surprising result of the Professor's study of the human remains found in recent years (see p. 497 ) is that men of quite a modern type lived quite as long ago as these supposed "missing links," and possibly before them.

\section{Remains of Fossil Man.}

IT is proposed in these pages to give a list of the discoveries of prehistoric human remains mentioned in Professor Keith's book, with some brief particulars in each case. It will be understood that the Professor's estimate as to the geologic age to which each skull, etc., belongs is founded on the bones of extinct animals, and the flint or bone 
implements, supposed to be the work of man, discovered in juxtaposition with it. These accompaniments denote what is technically called the "culture."

Geology recognises immediately before the present historic period in which we live, the prehistoric period, including the Iron, the Bronze, and the later Stone ages: in some uncivilised parts of the world, the natives are considered to be still in the Stone age.

Before this comes the Neolithic (new stone) period, and beyond this again the Palæolithic (old stone) period.

The Palæolithic period is considered by Dr. Keith (p. 62) to lie within the Pleistocene, or Glacial epoch. At this time the ice-cap covered all the northern portion of Europe and of North America. The Neolithic period may be taken as included in the Post-Glacial, or Recent epoch.

Going farther back, we come to the Pliocene period; before that came the Miocene, and before that again the Oligocene. We shall see that what are supposed to be the very earliest remains of man. are referred by Professor Keith, as well as by others, to the Pliocene. But there are many authorities who contest this.

Besides these geologic periods,. Professor Keith and other writers recognise certain periods of ancient time to which they have given names taken from some place or district where remains were found considered to be typical of the period, such as the Acheulean, the Chellean, the Solutrean, the Magdalenian, the Azilian, etc. Some of these are supposed to have come between the Palæolithic and the Neolithic periods.

There is very great uncertainty as to the length of time to be assigned to the various geological periods. The article Geology, in the Encyclo- 
padia Britannica, after mentioning some of the calculations as to the age of the earth, says, "But no one who has made himself familiar with the actual composition of these formations, and the detailed structure of the terrestrial crust, can fail to recognise how vague, imperfect, and misleading are the data on which such computations are founded." Not that the writer (Sir Archibald Geikie) would probably shorten the estimates, but his words show the uncertainty attending such calculations (Vol. xi., p. 651).

Professor Keith's estimates of time are necessar. ily vague. He thinks the Neolithic period may have covered 6,000 or 8,000 years. "We are on much surer ground, however," he says, "when we state that the period closed about 2,000 B.C., than when we date its commencement at 10,000 B.C." (p. 30). He speaks of the Acheulean and Chellean periods as covering 100,000 years between them (p. 209), and of the Mousterian period which followed commencing some 50,000 years ago (p. 102), these being included in what geologists name the Palæolithic period, or partly following it. As to the whole Pleistocene period, he mentions that estimates vary from 100,000 years to $1,500,000$; but he says: "The more I become familiar with the evidence relating to this period, the more my judgment is drawn towards the lower estimates" (p. 226).

We shall see later on that there are geologists of the first rank who do not at all accept these high figures.

We now come to the list of skulls, etc., mentioned in Dr. Keith's book, and they are in the order in which he gives them.

The question as to the antiquity of human remains must naturally depend on whether there is sufficient evidence that the person lived at the 
time of the deposition of the strata in which the bones were found, or whether it was a case of burial. This is never forgotten, but there are a few cases in which there may be a doubt.

In regard to flint implements, etc., it must not be forgotten that there is a possibility of forgeries, and some instances of these are given in Professor Keith's book.

It is principally in the skull of fossil man that characteristics are found that are pronounced to be simian, or ape-like. It will be noticed in the lists given in the following pages in how very many cases the skulls found are exceedingly defective, and in how many they were in fragments. Then it is confessed that in several cases of the reconstruction of a skull the mode in which the reconstruction has been carried out has been questioned. These considerations must clearly influence our judgment as to the results claimed.

\section{Neolithic Period.}

THE earlier chapters of Professor Keith's book mention skeletons or skulls found at the places named in the following list. These are assigned to the Neolithic period, and are all of modern type.

The pages referred to are those in The Antiquity of Man.

COLDRUM, Wes'T MaliING, Kent (p. 4.). Fragments of 22 skeictons found in 1910. Five fairly complete skulls.

MUSKhaM, NEAR NeWARK-ON-Trent (p. 14). Skull described by Huxley in 1862. He called it the "river-bed" type of skull.

Malita skull, described by Professor Sergi in 1912 (p. 15).

TII,BURY skull, found in 1883, supposed to be 7,000 or 8,000 years old (p. 27).

L.A MOTTEE, JERSEY (p. 32). Fragments of 
three skulls found in 1911, all of the "river bed" type. Probably belonging to a time when Jersey was united to England.

CARNON TIN WORKS, CORNIWALL (p. 35). Skull taken in 1809 from the submerged forestbed at a depth of 36 feet.

At SENNEN, NEAR LAND's END, a skull was found in 1862 (p. 37). It has not been preserved.

No Neolithic implements were found with any of these skulls in England.

Aberavon, NeAR Swansea (p. 39). Fragment of a skull found recently.

NEWPORT, SOUTH WALES (p. 40). Skull found in 1911.

MANCHester Ship Canal (p. 40). Skull found in 1890. Age doubtful.

MICKLETON, COTSIVOLD Hilis (p. 41). Skull found in 1852. Age doubtful.

\section{Pre $=$ Neolithic Man.}

THE following are classed under the head of "Pre-Neolithic Man," from the evidence-afforded by the bones of extinct animals and the flint instruments found in juxtaposition :-

Paviland Cave, Gower, South Wales (p. 47). Skeleton found in a cave in 1822 . Dean Buckland supposed the skeleton to have been buried in the cave, which contained bones of extinct animals.

Kent's Cavern, Torquay (p. 48). Flint implements and bones of extinct animals found in the cave in 1825 .

ENGis, NeAR Liegé (p. 48). Dr. Schmerling found a skull in a cave in 1833 : the face and jaw-bones missing. Sir C. Lyell was at first sceptical, but was afterwards convinced. Professor Boyd Dawkins, Dr. Rutot, and Pro- 
fessor Fraipont are not convinced that the skull was contemporaneous with the fossil animals.

Aurignac, Haute Garonne (p. 52). M. Edonard Lartet found 17 skeletons in a cave in 1860, accompanied by remains of extinct animals, flint implements, carvings in ivory, necklaces of shells and perforated teeth, etc. These were similar to remains found at Paviland and Engis, and are typical of what is called the "Aurignacian culture."

At Cromagron (p. 54) on a tributary of the Dordogne, M. I,ouis Lartet, in 1868, found remains of four skeletons in an old rock. shelter. They had massive skulls, but not unlike those of the river-bed type.

From 1866 to 1905 various discoveries of flint implements and other traces of man, with bones of extinct animals, were found at Mas d'Azil, Solutré (Saône), and other places, by Abbé Breuil, M. Piette, and others, and these are interpreted as proving periods of "culture" between the Paleolithic and Neolithic times which are called Solutrean, Magdalenian, and Azilian.

Mentone. Grimaidi Caves, and Grotte DFS ENFANTS (p. 63). Skeletons of six petsons were found in 1872, and later. Some were of the Cromagnon type: two had some negroid traits, but it may have been an aberrant Cromagnon form.

Dr. Duckworth, in Prehistoric Man (p. '51), says that the Grimaldi skeletons could be matched withont difficulty by skeletons of even recent date. He also says there is no adequate evidence of the contemporaneity of the animal remains found in the GROT'TE DES ENFANTs with the skeletons discovered there. 
BRÜNN, MoRavra (p. 69). Skull found in 1891 (Dr. Duckworth says 1871). A human figurine carved in ivory of a manmoth tusk found with it. Skull a variant of the Cromagnon type.

\section{Later Palæolithic Age.}

THE following are described in the chapters dealing with the later Palæolithic Age:-

H.ILING, on the MEDWAY (p., 71). Skeleton found in 1912. Not a single feature of the skull primitive or ape-like. It is the skull of a man under 40 .

A comparison of the strata in which the skeletons were found leads Professor Keith to believe that the Halling man lived 12,000 or 15,000 years before the Tilbury man, and to suppose that we must consider the Halling skeleton to be 25,000 years old. This wonld mean nearly a thousand generations.

Cresswell Craggs, Langwith, DerbySHIRE, (p. 84). Brain case of a skull found in 1903, face, teeth, and jaws gone. A few bones also found. No low or primitive feature in the skull. Professor Keith was at first doubtful about the antiquity.

WOOKEY HOLE, near WEILS (p. 92). Flint and bone implements found in 1859, with bones of extinct animals. No human remains.

Cheddir Cave (p. 93). Skeleton found in 1903. Skull of "river-bed" type.

Brixham Cave (p. 95). Flint tools and bones of extinct animals. No human remains.

Kent's CaVern, Torquay (p. 95). Bone and stone implements and bones of extinct animals found from 1864 to 1880 . Right half of a human palate found in 1867 . Exploration of the cave little more than hegun. 
Cissbury, near WORTHING (p. 99). Two skeletons of the "river-bed" type found in 1868. Cissbury was the home of a community of Palæolithic miners.

Admiralty Buildings, Westiminster (p. 100). In excavating the foundations in 1892 remains of arctic plants and Plcistocene mammals were found, and flint implements.

\section{Mousterian Period.}

THE following are classed as belonging to the Middle Palæolithic or Monsterian period:

CRAyFord, Kent (p. 104). Flint implements of Mousterian type found in 1905 with remains of extinct animals, which must have come from Siberia and Eastern Europe, in the Crayford brick earth. No human remains.

Other Mousterian work-floors found at GRAYs (Essex), at Acton, and at MIIDENHALI in Suffolk.

Professor Keith says : "Thus we have the most ample evidence that England was inhabited by men of the Mousterian culture; but so far not a trace of his actual body has been found. That is the more strange, seeing that remains of the animals of the period are well preserved" (p. 108).

Combe Capei, i, Dordogne Valitey (p. 109). Skeleton found in 1909: a man of modern type.

Dr. Duckworth says: "The skeleton lay in an excavation made for the purpose of interment. Stone implements of Aurignacian type were disposed around the skeleton."

La FerRassie, Dordogne (less than 20 miles from Combe CaPelle) (p. 112). Skeleton found in 1909. Skull broken beyond repair. Bones showed Neanderthal characters. 
Another skeleton found in 1910, showing Neanderthal characters.

LE MOUSTIER, DORDOGNe (p. 114). Skeleton found in a cave in 1908 ; a lad of 16 who had been deliberately buried. "The skull was badly crushed, and Professor Klaatsch was not altogether fortunate in the reconstruction of its fragments." All the curious features of the Neanderthal race are said to be shown.

Dr. Duckworth says: "The omission (by Professor Hauser, a Swiss) to inform or invite any French archæologists, and the immediate removal of the bones to Breslau, are regrettable incidents. . . The reconstruction cannot be described as a happy result of the great labour bestowed upon it. In particular it is almost certain that the skull is now more prognathous than in its natural state." (Prellistoric Man, pp. 39, 41.)

It is this Le Moustier find that gives the name to the Mousterian period.

la Chapeirik-1UX-Sampts, Corrèze (p. 115). Skeleton found in a small cave in 1908. "The skull was broken, parts of the face were defective, some parts of the skeleton were missing, but such blanks were supplied by the two skeletons found at La Ficrrassie" (p. 117).

Professor Keith says: "The La Chapelle man ... had many characters which may justly be called simian, or primitive, but he had others which cannot be so classed-such as the size of the brain and the relative proportion of the limbs."

Dr. Duckworth considers this skeleton very important, because the discovery was made by Dr. Boule and another very competent observer.

La Quina, Dordogne Vaimsy (p. 119). Human ankle bone found at the foot of an old 
rock shelter in 1910. Skeleton, probably of a woman, found in 1911. Professor Keith says the bones of the skull are of average thickness, and not thick like those of Neanderthal man, and the brain capacity about the same as that of modern women, but he appears to reckon it as a Neanderthal specimen in consequence of the prominent eyebrow ridges.

Four other discoveries of human jawbones or fragments of face-bones from 1889 to 1907 complete the list for France.

\section{The Neanderthal Race.}

THE following are described in the chapters relating to "Neanderthal man":

Gibraltar, Forbes QuarRy (p. 122). Skull found in 1848.

Professor Keith says: "The Gibraltar skull holds a unique place. In $n o$ other specimen is the base of the skull preserved." He says that the skull is remarkably straight and simian, and the nose is "reminiscent of the condition seen in the skulls of gorillas, yet the upper jaw is not projecting or simian: the face is not prognathous."

"The lower jaw was never found, aud a part is missing from the vault of the skull, leaving some doubt as to the exact size of the brain."

Dr. Keith says that no fossils nor implements were found with the skull, but in caves near, flints worked in the Mousterian manner have been found since.

Dr. Duckworth, who explored Forbes Quarry in 1910, say's that of the surroundings of the skull at the time of its discovery nothing is known, and that bones of recent mammalia, etc., found during the excavations throw no 
light on the subject. He also says that "corroborative evidence as to the geological or archæological horizon is lamentably defective." (Prehistoric Man, p. 19.)

The Gibraltar skull was quite neglected by scientists, until later discoveries seemed to some to connect it with the so-called "Neanderthal" race.

Jersey. St. Brelade's Bay (p. 125). Flint implements worked in the MIousterian manner, remains of ancient animals apparently used for food, and 12 human teeth were found in 1910 , and described by Dr. R. R. Marétt. The teeth show "Neanderthal" features.

Naulette, Lesse Valifey, Beigrum (p. 126). Human mandible found in a cave in 1866. "Oniy the region of the chin and the left part of the body of the jaw remain," says Professor Keith; "enough to tell us that it is from the face of a woman of the Neanderthal race." Mousterian implements and animal remains were found in the cave.

Grotte: DE Spy, near Namur (p. 127). Two skeletons were found in 1886 . "These Spy men," says Professor Keith, "were typical representatives of the Neanderthal species, with large, robust skulls, holding brains which, in point of size, were above the average of the modern European."

Dr. Rutot thinks that the Spy men were of the same date as those of Le Moustier, La Chapelle, and La Quina.

NEANDERTHAL CAVE, near ElBERFELd (p. 128). Parts of a skeleton, including the vault of a skull, found in 1857 , by Dr. Fuhlrott, who at first did not believe them to be remains of a human being: This is the "Neanderthal 
man," who has given the name to the "Neanderthal race."

Professor Keith says that " although the brain of Neanderthal man equals or exceeds that of the modern type of man in point of size, yet in its general conformation it resembles the brain casts taken from anthropoid skulls'" ( $p$. 139). He adds : "We feel assured that certain features of the face would have at once struck us as totally different from the corresponding features in all varieties of modern man. To find eyebrow ridges like those of Neanderthal man, great continuous horizontal bars of bone, overshadowing the orbits-a supra-orbital torus -we have again to refer to the anthropoid skull " (p. 140).

He afterwards mentions that "one simian feature is absent from the nasal region of the Neanderthal sku1l," what he calls " the simian nasal gutter," and this he finds in the COMBE CAPELLE sliull to a slight degree.

Taubach, near Weimar (p. 131). Two human teeth found in 1895. Professor Keith says : "These teeth, although they do not show the typical Neanderthal characters, may very well have belonged to an individual of this race."

Dr. Duckworth thinks them very ape-like.

Moravia (p. 132). In two cases, at ScHIPKA and at OcHos, fragments of a lower jaw were found in a cave in 1906 .

Krapina, Croatia (p. 133). Over 200 fragments of human skeletons, representing at least ten individuals, were found in a rock shelter from 1899 to 1905 . Over 200 human teeth were found, showing, in a varying degree, the characteristic form associated with the Neanderthal race, and over 2,000 bones of animals of the 
period. The skulls found are fragmentary; not one is complete. But Professor Keith says that "they are sufficiently perfect to show that they, carry all the marks of the Neanderthal race."

The children's skulls seemed of more modern type, and Professor Klaatsch and Professor Kramberger have suggested that different races are represented in the skulls, but Professor Keith does not agree.

Professor Duckworth examined the specimens in the Museum at Agram, and he discusses some peculiarities of the teeth found, and their similarity to the teeth of some of the other supposed Neanderthal men, but he says that the questions raised do not admit of a final answer. (Prehistoric Man, p. 28.)

\section{Neanderthal Man.}

A WHOLE chapter is devoted to the anatomical peculiarities of the Neanderthal man (chap. viii.).

Huxley, in his essay, On Some Fossil Remains of Man, wrote at considerable length on the comparisons between the skull of man and that of various animals. He devoted another essay to the Engis skull and the Neanderthal skull. The former he considered a fair average human skull; in the latter he found "ape-like characters, stamping it as the most pithecoid of human crania yet discovered." But comparing its capacity with Polynesian and Hottentot skulls he said that "in no sense can the Neanderthal bones be regarded as the remains of a human being intermediate between men and apes." He said: "It is closely approached by the Australiain flattened skulls," and "on the other hand it is more closely affined to the skulls of certain ancient people who inhabited Denmark during the Stone period." He added: "I may say that the fossil remains of man bitherto discovered do not 
soem to me to take us appreciably nearer to that lower pithecoid form, by the modification of which he has probably become what he is."

No implements were found in the Neanderthal cave, and no bones of extinct animals. It was uncertain whether the bones had been buried, or whether they had been washed into the cave. The workmen were very careless in collecting the bones, and secured chiefly only the larger ones. Huxley considered that the bones indicated a high antiquity. And yet there were circumstances that might be adduced against it. There was nothing decisive as to a geological epoch.

\section{Acheulean Period.}

THE following are assigned to the Acheulean period, supposed by Dr Keith to have lasted about 50,000 years, and to have ended about 50,000 years ago.

Swanscombe, neat DARTFORd (p. 161). Palæolithic implements found at times in gravel deposits supposed to have been laid down when the Thames was flowing at 100 feet beyond its present level.

DARTFORD (p. 166). Skull found in a pit in 1902. Brain capacity of the skull aboie the average ; nothing to distinguish it from modern skulls. Professor Keith says: "The evidence of the skull being Acheulean in date is purely presumptive. . We cannot cite it as evidence that men of the modern type lived in England during the Acheulean period; yet we cannot reject it, for it is probably authentic."

Bury S'r. EDmunds (p. 171). Part of the vault of a human skull found in 1882 . Fragment not sufficient to allow of reconstruction.

Hoxne, Vali,ey of the WaVeney (p. 171). 
Flint "spearheads," etc., found in 1797 by Sir John Frere.

Professor Keith says: "Considering the great duration of the Acheulean period, and the abundant evidence of the activity and culture of the men of that time, it is surprising that so little has been discovered of the men themselves" (p. 165).

\section{The Chellean Period.}

THE following are assigned to the Chellean period, which preceded the Acheulean :-

Gali,ey Hilit, Swanscombe, Kent (p. 178). Sku1l and parts of a skeleton found in 1888 . "Brain does not fall short of the average man of to-day." There was evidence of burial, but the men who found the remains said that the over-lying deposits were unbroken. Sir John Evans, at a discussion at the Geological Society, had some doubts.

Dr. Duckworth speaks of the difficult problems presented by the Galley Hill skeleton. While some authors accept it, "others reject its claims to high antiquity : of the latter some are courteous, others are scornful, but all are absolutely decided"' (Prehistoric Man, p. 57).

Professor Keith admits that "anatomists and geologists have been reluctant to acknowledge the antiquity of the Galley Hill remains."

\section{Pre-Mousterian Man.}

THE following are in the chapter on Pre-Mousterian man in France and Italy :-

ARBEVILLE (p. 196). Acheulean implements, etc., found by M. Boucher de Perthes in 1832.

Moulin QUignon, near ABbevilile (p. 197). Human jaw found in lower gravels of a pit, 
also a tooth. At a conference in 1863 the French geologists decided that the jaw was authentic, while the English regarded it as a forgery. Opinion is now almost unanimous in regarding it as a worthless relic. But Professor Keith thinks it should not be rejected.

FOXHALL, SUFFolK (p. 200). Jaw found in 1863 in a sand pit. Stratum it came from not known. It resembled the Moulin Quignon jaw.

CliIChy, PARIS (p. 202). Skeleton found in 1868 in a gravel pit. It had been buried. Skull similar to Galley Hill sku1l, but lower part of the forchead broken away. Lower limbs not similar to those at Galley Hi1l. M. Rutot visited Paris in 1910, and considers the terraces of the Seine to have been formed at the same time as those in the valley of the Meuse.

At GRENELLE human remains have been found (p. 205).

Le PUy, near Lyons (p. 205). Frontal bone of a skull found (before 1844) embedded in a volcanic matrix. Similar to a modern skull.

FlORENCE (p. 206). The Olmo skull, found in 1863 in a cutting near the Arno. No simian feature.

There is no certainty as to the age of this skull, but Professor Keith considers that it must be earlier than the Mousterian period.

\section{Ipswich and Cromer.}

IPSWICH (p. 211). Skeleton found in 1911 under a stratum of chalky boulder clay by Mr. J. Reid Moir. Skull much broken. It is of modern type. Shin-bone rather peculiar. Skeleton may have been buried from an old land surface ; it "cannot carry the conviction 
of a skeleton found at a depth which places its antiquity beyond dispute."

CROMER forest beds (p. 225). Worked flints collected by Mr. Reid Moir in 1910. Professor Keith admits that the "humanity" of the sub-crag flints "has been questioned, and even denied by men who have given the subject of flint fracture their serious consideration."

\section{The Mauer Jaw.}

MAUER, near HEIDELBERG (p. 232). A human mandible, or lower jaw, with teeth, was found in a sandpit in 1907. The bed in which it lay was covered by a series of deposits, amounting in all to 78 feet. Dr. Schoetensack recognised 24 different strata in the deposits, and the jaw was found in one of the lower strata. Remains of extinct animals were found in the lower strata corresponding to those in "the pre-glacial forest beds of Norfolk." M. Rutot also identifies the strata with a very early stage of the Pleistocene period.

Professor Keith says: "The front teeth-incisors, canines, pre-molars - of the Heidelberg mandible are of the same shape as those in the Spy mandible, only slightly larger." He contrasts them with the teeth of a Tasmanian, and says: "The Tasmanian teeth are quite different-more primitive." "If we confine our attention to the teeth, we have no hesitation in assigning the Heidelberg jaw to a primitive variety or race of Neanderthal man. From the very first anatomists have been struck by the apparent discrepancy between the 'humanity' of the teeth and the massive power-almost bestiality - of the jaw itself." At the same time, he says, "although the Heidelberg muscles of mastication must have been of great strength, yet the markings for their implantation on the mandible are those 
seen in human jaws-but never on the mandibles of anthropoid apes. . . There is no simian plate, nor any trace of it, in the Heidelberg mandible" (p. 242).

Dr. Duckworth says: "The one paradoxical feature is the relatively small size of the teeth.

The crowns of four have been removed by accident.

The teeth are actually within the range of variation provided by human beings of races still extant, though commonly regarded as 'prinitive,' if not pithecoid (such as the aboriginal race of Australia). Yet these teeth are planted in a jaw of such size and strength as renders difficult the reference of the specimen to a human being."

Dr. Duckworth further tells us (p. 65) that for some twenty years Dr. Schoetensack had kept in touch with the workmen of Mauer, anticipating the possibility of obtaining valuable fossil relics, and when the jawbone was found he was summoned at once, but, even so, the jaw had been removed from its resting place, and broken in two fragments.

\section{Italy, Africa, and Burmah.}

Chapters xiv. and xv. of Dr. Keith's book deal with some other discoveries :

Castenedolo, near Brescia (p. 245). Fragmentary vault of a human skull found in a pit in 1860. Scattered fragments of skeletons of two children, and skeleton of a woman, found in same pit in 1880 .

Only the woman's skull complete enough for reconstruction.

It is a skull of modern type, and is an exact counterpart of the Olmo skull.

Professor Sergi, then a rising anthropologist, examined the remains in $\mathbf{1 8 8 3}$, and was convinced he had discovered human remains in undisturbed beds of a Pliocene age. The 
leading anthropologists of Paris gave the discovery a mixed reception.

Professor Keith says: "A skeleton in a contracted posture must be regarded, unless proof to the opposite can be produced, as a burial, not necessarily from the present land surface, but from a land surface" (p. 251).

EGyPT. GEBEL MOYA, south of KHARTOUM (p. 254). Cemetery of pre-historic date dis covered in 1910. A tall negro race, 3,000 or 4,000 years ago, practising the same bodily mutilations as their modern successors.

Oldoway, German EAST AFrica (p. 255). Skeleton found in 1914 by Dr. Hans Reck, in contracted posture, in a stratum composed of calcareous sand, containing remains of extinct Pleistocene animals. This was probably a burial.

SOUTH AFRICA (p. 256). In river deposits Pleistocene cultures have been found with extinct animal remains.

BURmaH (p. 257). Dr. F. Noetling (1894) found a deposit with remains of Pliocene animals and flints worked by man. But 'the 'humanity' of Dr. Noetling's Burmah implements has been called in question."

\section{The Java Pithecanthropus.}

Java. The Pithecanturopus. The vault of a skull, a left thigh-bone, and three teeth, were found by Dr. Eugene Dubois, in a valley deposit near Trinil, in Java, in 1891 and 1892 . The skull and teeth were found together, the thigh-bone (femur) a few yards away a year afterwards.

In 1906 a German lady, Frau L. Selenka, with the assistance of certain German scientific societies, fitted out an expedition to continue the explorations at Trinil. A great harvest of fossil 
forms was collected, but no further trace of "Pithecanthropus" was discovered. Of the specialists who examined those remains, some pronounced them to be late Pliocene in date of formation, some as belonging to the older Pleistocene.

A fossil tooth was found in the course of the explorations, but, as we learn from Professor Branca, it was not found at Trinil, but at Sonde.

There has been an immense amount of discussion, especially in Germany, in regard to "Pithecanthropus," the chief question being whether all the remains found belonged to the same individual. Professor Keith believes that they did. In the skull he finds simian rather than human characters. But he admits difficulties in the measurement of the skull, because the temporal bone and earyassage are missing. He says: "In height of cranial vault Pithecanthropus is rather nearer to the anthropoid than to the human form. In total length and width of brain, however, Pithecanthropus is altogether human" (p. 264). As regards the rest of this body the Professor says: "In Pithecanthropus we find a being human in stature, human in gait, human in all his parts, save his brain" (p. 268).

Dr. Duckworth says, however, that "the human characters (of the thigh-bone) are by some absolutely denied."

\section{North and South America.}

Chapters xvi. and xvii. deal with discoveries in North and South America.

TRENTON, NEW JERSEY (p. 274). Part of a thigh bone and fragment of a skull (of modern type) found in gravel in 1899 . Stone implements had been found previously.

Natchez, on the Mississippi (p. 278). Pel- 
vic bone (modern type) found in ancient deposit about 1846. Sir C. Lyell was afraid to use it as evidence.

LANSING, near KanSAS CiTy (p. 280). Skeleton found in 1902, and a child's jaw, in a terrace of loess. The skeleton is that of an average Indian.

OMAHA, LONG's Hili (p. 282). A number of skeletons found in 1906, with some stone implements. Skulls had all the features that now characterise the American Indians.

California. Skull found in Cal.Averas county (p. 284). The greater part of the vault was missing. Professor Wyman said it showed no signs of an inferior race. Some other fragments of skulls found from 1857 to 1866 in Pliocene gravels, but Professor W. H. Holmes was doubtful.

Professor Keith says that until the question of Pliocene man in California has been settled by new exploration we must be content with the verdict of "not proven."

Lagoa Santa Caves, Brazil (p. 286). In six caves remains of man and extinct animals found in 1844 by Dr. Lund. In racial features no difference from present South American tribes.

BUenos AIres (p. 288). Human remains found by Dr. F. Ameghino from 1873 to 1902, and later. He regarded them as of Pliocene date, but his first discovery clearly represented a burial. Ameghino's scientific papers are marred by lack of precision and detail.

Dr. Duckworth says: "It is important to notice that time after time the attempts made to demonstrate the early origin of man in the American Continent have resulted in failure, 
which in some instances has been regrettably ignominious." (Prehistoric Man, p. 55.)

\section{The Piltdown Skull.}

Frow chapter xviii. to the end of Professor Keith's book the discovery of the human remains found at Piltdown, in Sussex, is very fully discussed.

PILTDOWN near LEWES. Fragments of a skull found by the late Mr. C. Dawson in a gravel pit, some parts in the autumn of 1911, and the rest in the spring of 1912 . The fragments were scattered some yards apart. The individual may have bein drowned in the stream. Implements and remains of ancient animals were also found.

Professor Keith thinks that the remains belong to the Pliocene age. Dr. Smith Woodward and others think the Pleistocene.

The name assigned to this relic of the past is "Eoanthropus Dawsoni." Of course a very great deal depends upon the reconstruction of the skull, and Professor Keith devotes several chapters to this.

Dr. Smith Woodward made the first reconstruction, and, noticing certain ape-like features in the fragments, "when he came to replace the missing parts of the jaws, the incisor and canine teeth, he followed simian rather than human lines" (p. 324). Professor Keith criticised the result. At last, "an approach to symmetry and a correct adjustment of parts came only after many experimental reconstructions" (p. 364). The fact that there. was " a triangular notch marking the point where evidently the workman's pick pierced the sku1l" (p. 347), cantiot have made the task an easy one.

Professor Keith speaks of a "remarkable mixture of simian and human characters" in the skull. The ape-like characters are found in the mandible and some of the teeth, which are pointed; but 
"the molar teeth are essentially human," and he seems to consider that the jaw also has some human characteristics. The discussion of these points is very lengthy, and highly technical. Professor Waterston doubted whether the mandible belonged to the skull. But, speaking generally as regards the skull, Professor Keith says: "The comparison of the fragments of the skull with corresponding parts of modern skulls convinces students of anatomy that in general conformation, in actual dimensions, and in brain capacity the head of the Piltdown race was remarkably similar to that of modern races"' (p. 375).

And, again, he says: "Piltdown man saw, heard, felt, thought, and dreamt much as we still do " (p. 429).

There is some uncertainty as to the sex, but Professor Keith inclines to think the skull is that of a woman.

As the strata in which it was found are considered to be so far back in the geologic scale, the question as to whether any ape-like characters can be traced in the skull is of special interest. Dr. Keith says: "When we come to build up the face our steps are not attended by the same degree of certainty. We have to base our reconstruction on the right half of the mandible. . A Are we certain that the mandible does form part of the same individual as the sku1l fragments? There are many who think it highly improbable that the tro do go together" (p. 430).

In another place he says: "Such difficulties, however, are not of so serious a nature as to make us actually reject the possibility of the mandible belonging to the skull; but a certain degree of doubt is engendered" (p. 440).

Supposing the mandible to belong to the skull, there is also an admission that the surface of the 
fossil bone may have been rubbed and smoothed as it lay in the gravel bed, and this might affect its appearance.

Dr. Keith says: "We can say with certainty that the forehead of Eoanthropus was well formed. It was high, prominent, and of a width equal to that of a modern human skull' (p. 496).

Finally, he says that while prognathism is a simian character, it was developed to only a slight extent in Eoanthropus, and not beyond the limits known to occur in living races, for instance, in the Tasmanians.

\section{Other Discoveries.}

THERE are two cases of discoveries of prehistoric human remains which are not in Dr. Keith's book.

A pamphlet recently published by the University Press at Cambridge, Notes on the Fenland, contains a description of the "Shippea man." A skull found in the fen-beds near Littleport is described by Professor A. Macalister. The protuberant brow ridges suggest a comparison with the Neanderthal man, but it is stated that the "Shippea man" cannot be older than Neolithic times.

At a meeting of the Royal Society on February 22nd, 1917, a description was given of a fossil human skull, found at Talgai, in Queensland, which was shown by Profossors Edgeworth David and J. T. IVilson at the meeting of the British Association at Sydney. An account in Nature (March 8th, 1917) speaks of it as " the highly fossilised and much fractured skull of a male youth, not more than 16." The brain case is well within the range of variation of modern aboriginal Australian skulls, to which it presents a very striking similarity in general conformation, as well as in respect of the distinctly Australian characteristics. But it appears that the 
"facial skeleton reveals an important contrast; the exceptionally large teeth-the canines especiallyhave been responsible for a great development of that portion of the alveolar process which lodges the incisor, canine, and pre-molar teeth."

The conclusion drawn, according to Nature, from this single specimen from the Australian Continent of a "highly fossilised and much fractured" skull is rather a wide one. "The fact that the brain case had already reached the stage represented in the modern Australian aboriginal, while the face still retained much of the grossness and uncouthness of the ape's, is a further confirmation of the view that, in the evolution of man, the brain first acquired the human status, and the refinement of the features came afterwards."

It will often be found that the erection of a large superstructure of theory upon a small basis of fact is a characteristic of writers on Evolution.

It may be pointed out that, while nearly all the reliable discoveries of prehistoric human remains have been in the south of England, France, Belgium, Germany, Spain, and Italy-parts of Europe to which the ice of the Glacial period probably did not extend-there have been only four or five questionable "finds" outside these limits, and those in such widely separated places as Egypt, German East Africa, Burmah, Java, and Queensland. No really trustworthy discoveries of such aneient human remains have been made on the American Continent. Later on in this book we shall see the most recent testimony as to supposed human implements found in the New World.

\section{"Reconstructed" Skulls.}

THE object of these details is to give to the student a brief survey of all the fossil remains of 
ancient man which are adduced by scientists as proofs of the descent of man from ape-like ancestors in some far-back geological epoch.

In nearly all cases it is the skull which is relied upon as evidence of animal origin, and it will be noticed at once how defective these ancient skulls are, and in how many cases only fragments of them have been preserved.

Professor Keith says: "As a rule little more than the vault of fossil skulls is found" (p. 377).

Of the Gibraltar skull he says: "In no other specimen is the base of the skull preserved" (p. 124) .

Of the Piltdown skull he says: "I was all along alive to the fact that we have as yet no means of drawing any accurate conclusion as to the shape of forehead from so small a fragment of it as was found by Mr. Dawson at Piltdown" (p. 387).

It has been necessary, therefore, in a large number of cases that these skulls should be "reconstructed," in order that some idea may be formed of their original condition.

Now, in several cases it is freely confessed that the results of such reconstruction have not always been satisfactory, and nowhere has this been shown more clearly than in Professor Keith's book.

"In skull reconstruction," he says, "nothing is truer than that one mistake leads to another, and the effect is cumulative" (p. 412).

In regard to the various reconstructions of the Piltdown skull, he says in different chapters :-

"I made an unpardonable blunder in two respects" (p. 387).

"We shall see, when we come to deal with the basal parts of the skull, that Dr. Smith Woodward has given the occipital bone an impossible position, thus contracting the posterior end of the skull " (p. 395). 
"In articulating the temporal bone, which contains the greater part of the temporal lobe of the brain, Dr. Smith Woodward tilted it too far forwards" (p. 411).

Another official reconstruction of the skull was exhibited at a meeting of the Geological Society in December, 1913, and of this he says: "The hinder. end of the skull has been opened out to a very considerable cxtent" (p. 399).

In commenting on the brain he says: "Thus an examination of the brain cast confirms the conclusion, reached from an examination of the skull, namely, that a mistake was made in the identification of the parts lying in the middle line, which greatly diminished the real size of the brain" ( $p$. 427).

And he comes to the conclusion that we have in the Piltown specimen "the certain asssurance that one race of mankind had reached, so far as the mass of brain is concerned, a modern human standard at the beginning of the Pleistocene period"' (p. 428).

As regards the Neanderthal sku1l, Dr. Duckworth says: "The reconstruction of the facial parts of the Neanderthal skull, as prepared by Professor Klaatsch, is shown to he much exaggerated" (Prehistoric Man, p. 36).

Again: "The reconstructed skull contains teeth which are large, and in the incisor region (i.e. in front) are much curved downwards in the direction of their length. But this, though probably correct. is yet a matter of inference, for only a couple of teeth (the second pre-molars on the left side) were found in situ" (p. 37).

We have already seen that as regards the skull found at Le Moustier (the place in the Dordogne that gives the name to the "Monsterian" period) both Professor Keith and Dr. Duckworth agree in 
saying that the reconstruction by Professor Klaatsch was not a happy one, and Dr. Duckworth says that it has made the skull more prognathous (i.e., in Huxley's phrase, more "snouty") than it was when its possessor was alive.

As regards the skull found at La Chapelle-auxSaints, we have seen it could only be reconstructed by copying parts of skeletons found at La Ferrassie.

Naturally it becomes a very serious question, when reconstruction often involves such uncertainty, and when there are so many pitfalls, how far it is possible to rely on arguments as to the early history of man drawn from these "reconstructed" skulls.

\section{Alleged Ape-like Skulls.}

WE must now proceed to consider rather more fully certain of the skulls or other remains mentioned in the aforegoing pages upon which Dr. Keith relies as proofs of the evolution of mankind from the animal. It will be understood, from what has been already said (p. 2), that he does not consider these to be remains of ancestors of modern man: he looks upon them as types of races of men which have died out, leaving no descendants, but who bore traces of animal ancestry, while such other races, as the Cromagnon men, living about the same time, although also originating from an animal stem, had so far developed as to have lost all marks of it in the framework of the body.

\section{The Pithecanthropus of Java.}

WE will first of all see what is said about Pithecanthropus in such recent scientific books as would generally be consulted by students of the present day. 
The Cambridge Natural History (vol. x., p. 585) says: "Pithecanthropus. There is hardly an anatomist or an anthropologist who has not had his say upon this regrettably very incomplete remnant. The creature is only known by a calvarium, two separate teeth, and a femur. And the femur, moreover, is diseased. The skull in its profile outline stands roughly midway between that of a young chimpanzee .. . and the lowest human skull, that of the Neanderthal man. This creature is truly, as Professor Haeckel put it, the long searched for missing link, in other words represents the commencement of humanity."'

The Encyclopcedia Britannica in the article Pithecanthropus (Vol. xxi, p. 665) says: "The prevailing opinion is that the bones are human. They are not held to represent what has been called the missing link . . . hut almost all authorities are agreed that they constitute a further link in the chain, bringing man nearer his simian prototype."

In the article Anthropoid Apes it says: "There is a great gap to be bridged between the highest anthropoid and the lowest man, and much importance has been attached to the discovery of an extinct primate, Pithecanthropus, which has been regarded as the missing link." (Vol. ii., p. 108.)

Professor G. Schwalbe, in his article on "The Descent of Man" in Darrvin and Modern Science (the Darwin Centenary Volume), says (p. 127): "What Darwin missed most of all-intermediate forms between apes and man-has been recently furnished. E. Dubois, as is well known, discovered in 1893, near Trinil in Java, in the alluvial deposits of the river Bengawan, an important form represented by a skull-cap, some molars, and a femur. His opinion-much disputed as it has been - that in this form, which he named Pithecanthropus, he has found a long-desired transition form, 
is shared by the present writer." Further he says (p. 135) that he considers Pithecanthropus "as the root of a branch which has sprung from the anthropoid ape root and has led up to man."

Professor E. W. MacBride, in his Zoology (p. 84) says: "Some of the oldest skulls show in their projecting brows and flat brain cases unmistakable resemblances to those of the ape. One fragment named Pithecanthropus-literally ape-man-found in Java, seems to indicate a size of brain exactly intermediate between that of the highest ape and that of the lowest men living to-day."

Professor Haeckel, in his Evolution of Man, accepts Pithecanthropus as a link in his genealogical chain.

His disciple and translator, Mr. Joseph McCabe, in Evolution from the Nebula to Man (p. 93), says: "When Dr. Dubois brought to Europe from Java in 1894 the four bones... he had found, there was an intense conflict of opinion as to their nature. . . To-day, casts of the skull of Pithecanthropus erectus are given unhesitatingly in our Museums (South Kensington, College of Surgeons, etc.) as the first human skull, and there is general agreement that it belonged to a stage mid-ray in development between the anthropoid ape stage (or its equivalent in human evolution) to that of Palceolithic man... . It was the 'missing link.',

Dr. Woods Smyth, in his Facts and Fallacies regarding the Bible (p. 70), gives a photograph taken from a collection in the South Kensington Museum. He says: "At the top is a skull of the average man of to-day; next below is the skull of the man of Spy, next the Neanderthal man, and, lastly, the link with the ape, the Pithecanthropus erectus, or the erect ape man, from the upper Pliocene of Borneo." (Of course, he means Java.)

$\mathrm{He}$ adds (p. 69) that there is evidence to show 
that men of this early age "were preceded by lower races of men, going back in links to generalised forms related to anthropoid or man-like apes."

In Evolution, by J. A. S. Watson, published in 1915, in the Through the Eye series, we find the following: "There can be no reasonable doubt that man has evolved from an ancestor which, if it existed to-day, we should without hesitation class as an anthropoid ape. Could any doubt have remained, it would have been set aside by the discovery, in 1891, of a being occupying a position about midway between the highest apes and the most primitive known man. This is the Pithecanthropus, whose remains were discovered in Java in a volcanic deposit of somewhat doubtful age. . . From the fragments of the skeleton numerous deductions have been drawn, of greater or less probability. It may be said with practical certainty, however, that this ape-man was of the size of a smallish man, and that he was accustomed to walk and stand in the characteristically human erect attitude" (p. 150).

\section{Other Opinions as to the Pithecan- thropus.}

THERE are other authorities, however, who do not speak so positively.

Mr. R. R. Marett, in his Anthropology in the Home University Library, says :-

"By itself stands the so-called Pithecanthropus (ape-man) of Java, a regular 'missing link.' . . . It must remain, however, highly doubtful whether this is a proto-human being, or merely an ape of a type related to the gibbon. The intermediate character is shown especially in the head form. If an ape, Pithecanthropus had an enormous brain; if a man, he must have verged on what we should consider idiocy" (p. 76) 
Dr. E. B. Tylor, in his article Anthropology, in the Encyclopcedia Britannica (Vol. 2, p. 112), siys : "Classing the Trinil skull as human, it may be described as tending towards the simian type more than any other known." Later on he says: "The existence of man in remote geological time cannot now be questioned, but despite much effort made in likely localities, no bones, with the exception of those of the much discussed Pithecanthropus, have been found which can be regarded as definitely bridging the gulf between man and the lower creation" (p. 119).

Professor E. Metchnikoff, the late head of the Pasteur Institute at Paris, says of Pithecanthropus in his Nature of Man (p. 49):-- "However, the facts about this creature are meagre, and have been interpreted differently.'

Dr. Duckworth, in his Prehistoric Man, states rather fully the objections made by different writers, several contending that the bones could not form parts of one skeleton, and others contesting the geological age of the specimens, but he comes to no definite conclusion (pp. 2-9).

Professor E. D. Cope, in The Primary Factors of Organic Evolution, admits the uncertainty as to all the bones belonging to one skeleton when he says: "The tooth was found close to the skull, and belongs probably to the same individual as the latter, while the reference of the femur is more uncertain, as it was found some fifty feet distant"' (p. 168).

Dr. J. H. F. Kohlbrugge, in Die Morphologische Abstammung des Menschen (pp. 8, 9), discusses the opinions of Schwalbe, Klaatsch, Volz, Bumüller, Kollman, and others, and mentions the possibility that bones of a man and of an ape may have been washed together into the same stream, or that an ape and a man may even have been drowned when engaged in conflict together. In 
regard to some speculations of Professor Schwalbe as to possible ancestors of Pithecanthropus, Kohlbrugge remarks: "This opinion, compared with others that have been cited, shows us that we have here not to deal merely with comparisons with one, two, or three unknown forms, but that the number of the great unknown grows so large that our actual knowledge becomes a small point, upon which a hypothetical pyramid is built with its basis in the air" (p. 12).

He also says: "The great antiquity ascribed (to Pithecanthropus) appears to be altogether doubtful." And again: "Nothing compels us to conclucke that the thigh-bone and the skull belonged to one another." He says further that, according to Bumuller and Klaatsch, the form of the thighbone did not justify the title "erect" (Pithecanthropus erectus).

Professor Richard Hcrtwig,-in his Lehrbuch der Zoologie, says: "The fragments were regarded by some as belonging to a connecting lin between apes and man, Pithecanthropus Erectus Dubois; by others they were thought to be the remains of genuine apes, and again by others to be those of genuine men. "The opinion that is most probably correct is that the fragments belonged to an anthropomorphic ape of extraordinary size and an enormous cranial capacity, and with a relatively very large brain." (See Modern Biology, p. 466.)

'The Rev. E. Wasmann, in his Modern Biology and the Theory of Evolution (translated from the German), says: "It is nothing short of an outrage upon truth to represent scanty remains, the origin of which is so uncertain as that of the Pithecanthropus, as absolute proof of the descent of man from beasts, in order thus to deccive the general prublic" (p. 465).

Wasmann says further: "Macnamara has re- 
cently submitted the skull of a chimpanzee and the much discussed Pithecanthropus cranium to a very careful comparison and examination, in consequence of which he has arrived at a similar. conclusionnamely, that the Pithecanthropus was a true ape of large size. . . Almost the sole difference between them is in size, and for this reason Macnamara gives it as his opinion that 'the cranium of an average adult male chimpanzee and the Java cranium are so closely related that I believe them to belong to the same family of animals-i.e., to the true apes."' (Macnamara nevertheless appears to have a theory as to the Java skull in some way bridging the interval between ape and man).

Professor Otto Hamann, in Die Abstammung des Menschen, says of the thigh-bone: "According to the researches of Bumüller, carried out under the guidance of Ranke, it is the femur of an ape, and belongs probably to the Hylobates (Gibbon) branch of the anthropoid apes, which Wilhelm Krause, who had the original bones before him, said was 'undoubtedly' the case. Klaatsch also agreed in this judgment"' (p. 16).

"The teeth, according to W. Krause, are decidedly the teeth of an ape" (p. 17).

\section{Virchow and Branca on Pithecanthropus.}

PROFESSOR W. BRANCA, in Der Stand unserer Kentnisse vom fossilen Menschen (The position of our knowledge of Fossil Man) annswers the objection put forward by Dr. Dubois as to the size of Pithecanthropus being too large for that of an ape, and says: "Why should there not have been large gibbons at that period? We see, indeed, as has recently been proved, that in Madagascar, while only lemurs of small size are now to be found, 
some giant lemurs lived in former time" (p. 75). Dubois said that gibbons as large as men would never have been able to pursue their gymnastic exercises on the branches of trees, but Branca replies that they would soon give up their antics when they found trees breaking under them.

But the opinion which has by far the greatest weight comes from the late Professor Rudolf Virchow, who was for thirty years the President of the Berlin Anthropological Society, and Editor of its organ, the Zeitschrift fïr Ethnologie, and for fifty years cdited also the Archiv fïr pathologische Anatomie and Physiologie. In the Zeitschrift we see how Virchow constantly presided over discussions at the Anthropological Society on skeletons and skulls from many parts of the world, and he had special opportmities of examining the Java specimens, and of taking careful and accurate measurements.

In September, 1895, Virchow presided over the Third International Congress of Zoologists in Leyden, when Dubois gave an account of his Java discovery. Wasmann says: "Virchow uttered a very courteous but crushing criticism upon the speaker's remarks, and showed that it was by 110 means certain that the remains had all forned part of the same individual, and that it was still less possible to decide whether that individual was a man or an ape" (MIodern Biology, p. 465).

The subject was considered at several meetings of the Berlin Anthropological Society, and in December, 1895, Dubois was received by the Society, and there was a very full discussion of the paper read by him. Virchow had by that time had the opportunity of carefully examining the skull. In his summing up at the close of the debate, he said that he had come to the clear conclusion that the skull had not belonged to a man, but that it showed the 
greatest similarity to the skull of a Hylobates (Gibbon). According to all the rules of classification, he considered the being an animal, and indeed an ape. He had compared the original drawing made by Dr. Dubois, of the correctness of which he had assured himself, with that of a skull of a Hylobates, taken from nature, and there was as great similarity as one colild expect between two individuals of the same species. He then went fully into details of the measurements he had taken.

As to the teeth, they appeared to him much more ape-like than human. Their size and form did not accord with that of a man's wisdom tooth.

As regards the thigh-bone, he said that in spite of its similarity to the os femoris of a man, there was so much agreement aiso with that of a gibbon, that he saw no difficulty in its having belonged to a large-sized Hylobates.

There was some further discussion at the meeting in regard to the injury to the thigh-bone, which had apparently healed, but Professor Virchow said he had seen the same thing in apes of the present day.

But there remains another important questionthat of the age of the deposits at Trinil in which the remains were found, and this is treated rather fully in the work of Professor Branca. He says in his preface: "The doubt which in 1901 I was obliged to express of the Pliocene age of Pithecanthropus has now, through the researches of several geologists and those of several palaeontologists, who have found fossil molluscs and plants in the strata, been much strengthened."

On page 57 of his book he says: "How clearly I was right in saying, in 1901, that in considering the Tertiary forefathers of man we must put Pithecanthropus on one side, as his Tertiary age had been in no way proved, has been shown by the re- 
sult, as recently from several different quarters a diluvial, and partly a middle diluvial age has been asserted for the strata in which Pithecanthropus was found.

"First of all, Martin, in Leyden, on purely palæontological grounds, from the examination of fossil fresh-water molluscs which have been found in the strata, has drawn this conclusion; while he showed that the specimens given to him belonged generally to species still living.

"Then Volz has decided for only a middle diluvial age on purely geological grounds." (These are stated.)

"Further, Elbert has spoken in support of a -niddle diluvial age on both geological and palæontological grounds."

Branca devotes a whole chapter to this subject, and shows the groundlessness of Haeckel's assertions that we know the Tertiary forefathers of mankind.

It should be understood that Professor Branca (who is Professor of Geology and Palæontology in the University of Berlin) is in no way a defender of the Mosaic account of the creation of man, and, indeed, he encrgetically protests against this accusation made by some of his opponents; he thinks that there must have been men in Tertiary time, but his point of view is that hitherto we have no evidence of them.

It has been necessary to go so fully into the question of the Pithecauthropus because several of the leading works which students of biology are likely to consult speak so confidently of him as a missing link, and he appears to be treated as such in our Museums, while nothing is said whatever of the decided opinion of such an eminent man as Virchow, who had the fullest opportunity of examining the remains, or of the uncertainties in re- 
gard to the strata in which these remains were found.

Professor Schwalbe, certainly, in Darwin and Modem Science (p. 128), admits the later date of the Trinil deposits.

Of course, as we have seen, Professor Keith gives ap the "missing links" altogether, but he treats Pithecanthropus as human, and as a relic of the earliest branch of humanity that sprang from the original animal stem.

\section{The Boanthropus of Piltdown.}

THu discovery of Piltdown man is so recent that it is not mentioned in our ordinary text-books.

But Professor H. F. Osborn has recently published (May, 1916) some lectures he delivered in A merica in 1914 under the title of Men of the Old Stone Age, and in the preface he says: "The problem of reconstruction of the Piltdown skull has, through the differences of interpretation by Smith Woodward, Elliot Smith, and Arthur Keith, become one of the causes célèbres of Anthropology. On the placing of the fragments of the skull and jaws, which have few points of contact, depends the all-important question of the size of the brain and the character of the profile of the face and jaw."

A little later on he says: "I have placed Piltdown man in a comparatively recent stage of geologic time-an entirely opposite conclusion to that of Dr. Smith Woodward."

Professor Osborn gives two portraits of the Piltdown man, and, indeed, he gives two portraits also of Pithecanthropus.

But in the Appendix to Men of the Old Stone Age there is the following note (Note ix): "Doubts which have been entertained from the first by many anatomists as to the association of 
the Piltdown jaw with the Piltdown skull appear to be entircly confirmed by the recent exhaustive comparative study marln by Crerrit S. Miller, Jr., of the United States National Museum. He has shewn that those portions of the Piltdown jaw preserved, including the upper eye tooth or canine, are generically identical with those of an adult chimpanzee. . . This conclusion, which has been accepted by several eminent comparative anatomists, has two very interesting results; first, it deprives the Piltdown specimen of its jaw and compels us to refer the skull to the genus Homo rather than to the supposed more ancient genus Eoanthropus; secondly, it demonstrates the presence of anthropoid apes in Europe during the Glacial Epoch, a fact upon which doubt is cast on page 54 of this work, but which tends to be confirmed by the presence of the supposedly human tooth of Pleistocene age found at Taubach, and identified by Miller as belonging to pan velus, the same species of chimpanzee as that represented by the Piltdown jaw.'

In Science Progress for January, 1917, there is. however, an article by Mr. W. P. Pycraft, of the Zoological Department of the British Museum, on The Jaw of the Piltdown Man, strongly attacking Mr. Miller's contention. It extends to twenty pages, and is highly technical, dealing to a great extent with the teeth. Mr. Pycraft says that an "unfortunate lack of the right perspective has caused Mr. Miller to overlook some of the most significant features of these remains, and has absolutely warped his judgment." He speaks of his argument as a "crude deduction founded on false prerinises" ; and further on he says: "Mr. Miller's statements ... show either a very superficial acquaintance with the morphology of the human jaw, or a habit of basing far-reaching conclusions on illdigested data." 
The argument in the article turns a great deal upon the teeth in the Piltdown jaw, and their state of wear. One would imagine that this must be a difficult point to judge of in fossil teeth of such antiquity. Mr. Pycraft's great contention is that the jaw is not that of a chimpanzee, and he is supported in his view by Dr. Smith Woodward, Professors Elliot Smith, Arthur Keith, and A. S. Underwood, and Dr. Broom, while Dr. W. K. Gregory, of the American Museum of Natural History, in Studies on the Evolution of the Primales, throws the weight of his authority on the side of Mr. Miller.

But on page 391 of Science Progress Mr. Pycraft says: "As a matter of fact, the Piltdown skull, even with this jaw, was less prognathous than in many modern men. This much is demonstrated by the restoration of the skull made in the American Museum of Natural History, New York."

Does not this conclusion take away at once from the Piltdown remains all claim to proof of animal descent? After all, it is not far from what Professor Keith said in The Antiquity of Man (p. 375). (See page 24 of this book.)

Mr. Pycraft does not mention what Professor Osborn says in Men of the Old Stone Age-that he places Piltdown man in a comparatively recent stage of geologic time; so that not only the simian character but also the antiquity of the skull is gravely questioned.

\section{The Neanderthal Man.}

We now come to what is known as the "Neanderthal race," and we will, first of all, consider the "Neanderthal man" himself.

We have seen that Huxley came to the conclusion that the Neanderthal skull, though showing some simian characters, could in no sense be 
considered to belong to a being intermediate between man and the ape.

Professor Rudolf Virchow, the President of the German Anthropological Society, was, of course, in a specially favourable position to obtain the fullest information and to form a judgment, and his opinion was that the Neanderthal man was a diseased subject. He said: "We may certainly regard it as decided that the brain-cast bears no resemblance to that of an ape, and even if the cranitun is admitted to be a typical race-cranium (which I consider quite unjustifiable), it does not by any means follow that we may deduce from this that it is approximate to that of an ape."

Professor G. Schwalbe, of Strassburg, in his essay on The Descent of Man in Darwin and Modern Science, says that "the most varied judgments have been expressed in regard to the significance of the retnains and of the skull in particular" (p. 128).

MM. Frainont and I ohest say: "Pruner-Bey saw in the Neanderthal skull that of an idiot. De Quatrefages considered it at first as an individual exception due probably to the dolichocephalic race of the dolmens (a Celtic race). Rodolph Wagner was of opinion that the skull might be that of a modern Dutchman; von Mayer that it night be that of a Cossack buried in 1813 or 1814. Barnard Davis saw in the extraordinary form of the skull the result of the premature ossification of the sutures of the temporal region. . . . Only Schaffhausen and Hamy dared to affirm positively that the remains belonged to a special race" (La race humaine de Neanderthal, pp. 697, 698).

Huxley, however, in his essay On Some Fossil Remains of Man, said that a safe judgment was greatly hindered by the absence of the jaws, so that there was no means of deciding with certainty 
whether the cranium was "more or less prognathous than the lower existing races of mankind."

Professor W. Branca, in The Position of our Knoreledge of Fossil Man, says: "This diluvial, inferior type of skull has been found to-day anongst the Australians," and Professor H. Klaatsch says that the Australian skull is still lower in type than the Neanderthal skull.

Branca also says (p. 44) that Vircliow, on the occasion of an Anthropological neeting at the Hague, had declared that he had then seen upon the street men with just such skulls as those of the Neanderthal type.

Dr. Duckworth compares the skeleton found at La Chapelle-anx-Saints (p. 10) with that of Neanderthal man, and finds that they resemble one another very closely. He says: "Prognathism-i.e., projection of the jaws-though distinct, is less pronounced than might be expected. Hereby the reconstruction of the facial parts of the Neanderthal skull, as prepared by Professor Klaatsch, is shewn to be much exaggerated" (Preluistoric Man, p. 36).

But not only is there great conflict of opinion as to the character of the skull but also as to the age of the deposits in which it was fonnd.

Dr. Duckworth says that "corroborative evidence as to the geological or archrological horizon is lamentably defective."

$\mathrm{He}$ also says that conclusive evidence as to the antiquity of the skull, "as distinct from presumption, is unfortunately lacking"' (p. 19).

Mr. R. R. Marett, in his Anthropology, speaking of Neanderthal man, says: "It was unfortunate that there were no proofs to hand of the age of these relics" (p. 78).

Professor Rauff pointed out that no competent judge saw the Neanderthal skeleton in its original position (Wasmann, p. 470). 
And Professor W. Branca says: "The diluvial age of the Nieanderthal skull has, through Rauff's enquiries, been proved to be absolutely doubtful. The Neanderthal skull must finally be struck out of the list of apparently safe diluvial skulls'" (Fossil Man, Preface, 1. v.).

\section{The Spy Skeletons.}

We should perhaps never have heard of the Neanderthal race but for the discovery in 1886 of the two skeletons at Spy. The Encyclopedia Britannica, in the article Neanderthal, says of the Neanderthal skull : "Professor Virchow and others contended that the remarkable shape was pathological, or caused by disease during the lifetime of the individual. 'The subsequent discovery of tro other skulls, almost identical in form, at Spy, in Belgium, have helped to prove its typical character. The now generally accepted view is that the Neanderthal skull represents the oldest known dolichocephalic race in Furope."

Professor E. D. Cope says: "What had long been suspected is now established, through the discovery and descriptions of Messrs. Fraipont and Lohest, of Liége, viz., that there dwelt in Europe during Palaeolithic times a race of men which possessed a greater number of simioid characteristics than any which has been discovered elsewhere. The important discovery in the grotto of Spy of two skeletons, almost complete, served to unify knowledge of this race, which had previously rested on isolated fragments only. These skeletons proved, what had been previously only surmised, that the lower jaws of Naulette, and of -Schipka, and probably the skeleton of Neanderthal, belong to one and the same race" (Primary Factors, p. 161).

Further on, he says: "No human race presents the characters of the lower jaw exhibited by these of Spy, Naulette, and Schiplia." He then goes on 
to compare the remains with those of Pithecanthropus.

Dr. G. F. Wright, in The Origin and Antiquity of Man, refers to the Spy remains as "two complete skeletons," or nearly so (p. 322).

We will now turn to the original account of the finding of the skeletons which Professor Cope speaks of as " almost complete," and Dr. Wright as "complete."

In L'Homme Contemporain du Mammouth à Sty (p. 25), we read:-

"A first skeleton, unfortunately rather incomplete, was found at six metres to the south of the entrance to the grotto; another, likewise very incomplete, at cight motres to the south of the same point, and a little to the west of the first.

"The position of the first skeleton, which we shall call Spy No. 2, was difficult to explain precisely. The bones were found displaced from their natural connections, and the skull was broken into about forty pieces.

"The second skeleton, which we shall call Spy No. 1, appeared lying on the right side, the hand resting against the lower jaw.

"It was placed almost across the middle line of the grotto, the head towards the east, the feet towards the west. Many bones could not be found in spite of the most minute search. The skull was broken. Many fractures were very old, pieces displaced from the anatomical connections being reconnected by calcareous incrustations.

"We saw that calcareous blocks of many cubic metres in size had fallen upon the terrace. The falling to pieces of the skeletons was probably due to these falls. The study of the fractures of the bones confirms this view. When we had picked up the lower jaw of Spy No. 1 it was broken in the line of 
the symphysis, and a phalanx of the hand caught in the middle of the fracture, and the whole was reconnected by a clump of clay."

A postscript to the report says:

"Notwithstanding all the precautions, a human humerus (upper bone of the arm) was broken in trying to extract it from the clay and stones amongst which it was firmly fixed."

On pages $625-7,631,652$, and 656 of the same report we read: "The cheek bones only exist in part in skull No. 1. The one on the right side has lost the extremities which should join it with the zygomatic apophysis and the maxillary bone.

"The existence of this part of the cheek bones in connection with the orbital apophyses and the arches, permit us to recognise how large and deep were the orbital cavities of the men of Spy."

"Of the upper jawbone only fragments have becu collected."

"The lower jaw is very well preserved in skeletoli No. 1. Only the extremities of the coronoid apophyses and the condyles are wanting. If we had possessed these latter, the important question of the facial prognathism or the orthognathism of the Neanderthal race would have been decided."

"We have not been able to determine the mandi. bular angle; the region of the angle of the jaw being missing on this jaw. The branches of the lower jaw of No. 1 are in fact incomplete."

"The posterior, or parotid border, the angle of the jawbone, the condyles with their neck, the extremities of the coronoid apophyses are, as we have already said, wanting."

THF ARM.--"The four humerus bones of the two skeletons have been recovered, but they are inconplete. All four are broken in the parts near the head. Those of the second skeleton are stronger 
than those of No. 1. They are short and heavy."

"The skeletons appear to be of the same height as that of modern Europeans; not as long as those of African negroes generally."

FEMUR. - "There has been found at Spy only the entire right femur (thigh-bone) of skeleton No. 1 , and the head with the upper half of the left femur of skeleton No. 2."

"The incurvation, or anterior convexity of the body of the femur, is quite characteristic. It does not exist, to our knowledge, in any modern race except amongst the Negritos of the Philippines."

From another report in the Archives de Biologie, we learn that Professor Virchow went to Liége to examine the skeletons, and he pointed out a mistake that had been made in the "reconstruction" process that was needful. The report says: "He told us that in the reconstruction we had certainly raised the temporal bone a little too much in proportion to the parietal and occipital bones. He made us notice, in fact, that in the position we had given to this temporal bone its zygomatic apophysis could not accord with the corresponding branch of the cheek bone, following a horizontal line, as is the normal condition in all human skulls.

"We admitted this well-grounded criticism. We should not have been able to change the position given to this bone withont the risk of compromising the condition of the rest of the skull which the eminent professor of the University of Berlin was good enough to declare perfectly reconstructed. We had besides at the time of his visit already had the reproduction of skull No. 1 executed in this condition" (p. 615).

As regards the age of the two skulls, the former report says: "We dare not speak categorically on the subject of their contemporaneity. We have, as shewn above, satisfied ourselves concerning the 
geological age of the men of Spy, without wishing, however, to affirm that man No. 1 lived at the same time as man No. 2"' (p. 704).

\section{Age of the Spy Relics.}

Asout a year before his death, Professor Virchow read a paper at the Anthropological Congress at Metz (August 5th to 9th, 1901) on Prehistoric Man, and the Borderland between Variety and Species, in which he dealt with Neanderthal man and the Spy skeletons. I have not succeeded in finding a report of the Metz Congress in the British Museum Library, but Professor Schwalbe, in a paper which appeared the next year in the illustrated periodical, Globus, referred to Virchow's address, and said that he had spoken of the skeletons found at Spy as those of Frisians, and had left the impression that "these ancient skulls from Spy, the geological age of which had been established by Fraipont and Lohest, were only forms which to-day are represented by certain exceptional Frisian skulls" (Globus, Vol. 1xxxi., p. 168).

But the geological age of the Spy skeletons does not appear to be so certain as is assumed by Professor Schwalbe. In the French journal L'Anthropologie for 1906, we find an article by Professor Hugues Obermaier on Quarternary Human Remains in Central Europe, in which he says: "The majority of learned men attribute to the human remains at Neanderthal, for anatomical reasons, the same antiquity as the Spy skeletons, which they speak of as being of the Mousterian age.

"For my part I consider it very problematical whether they belong to the Mousterian. The interior of the grotto of Spy . . . contained a Mousterian layer upon which was superimposed a level which recalls in a striking manner the 'Solutrean' of Mentone, and which should be placed at the be- 
ginning of that epoch (as Presolutrean). The terrace before the grotto did not contain any Mous. terian layer, but at the base the human skeletons, above which was found the said Presolutrean layer, which was still covered over by some more recent Palæolithic vestiges. The study of the strata demonstrates that the present valley of Orneau was already almost completely formed when the lower layer of the terrace containing the skeletons was deposited. . . . It is not impossible that at Spy we are in the presence of burials of the beginning of the Solutrean age, and not of the Mousterian. The burials at Mentone and at Predmost would be striking parallels" (I'Anthropologie, Tome xvii., p. 55, et sca.).

If the Spy skeletons are Solutrean or Presolutrean instead of Mousterian it makes an immense difference as to their geological age. Dr. Duckworth says: "The consensus of opinion regarding the position of Solutré (i.e., its typical implements) is very extensive and quite definite. In effect the type of Solutré is assigned to the newer loess deposits. But these are also widely recognised as entircly post-glacial"' (Prehistoric Man, p. 124).

Professor Keith, in The Antiquity of Man, gives a diagram showing the strata at the rock-shelter at Combe Capelle, and they come in this order of antiquity: Mousterian, Lower Aurignacian, Sterile Layer, Middle Aurignacian, Sterile Layer, Upper Aurignacian, Sterile Layer, Solutrean Culture (the latter next to the upper soil) (p. 110). At Solutré itself, the Solutrean stratum is only a few feet from the surface (p.60).

\section{Other Alleged Neanderthal Remains.}

Professor Cope, in his Primary Factors (pp. 160170 ), does not lay any stress on the "Neanderthal man," but rests his argument for the Neanderthal 
race on the Spy skeletons, and the lower jaws of Naulette, and of Schipka. The remains at Krapina, La Chapelle, La Quina, and others had not been discovered when he wrote.

As regards the Naulette and Schinka jaw. bones, Professor Virchow, at the meeting of the Berlin Anthropological Society in May, 1886, said, in reply to Hert Maska, the discoverer of the latter: "According to my opinion there is nothing left for us but to suppose that both these lower jaws were brought from somewhere or other to the place where later they were found. If they were perfect, one might think that they had been kept as amulets, or at least as sacred objects, a thing that happens at the present day in New Guinea and the neighbouring islands. But the fragment from the Schipka-Höhle is so small and shows such sharply fractured edges, that we must conclude with certainty that it came as a fragment to the place where it was discovered" (Zeitschrift, Vol. 1886, p. 349).

We have seen that of the Naulette mandible only the region of the chin and the left part of the jaw remain (1. 12).

In the Zeitschrift for 1882 (p. 301), Virchow showed that the Naulette skull differed 1nuch from that of apes. This is mentioned in MM. Fraipont and Lohest's book on the Spy skeletons (p. 143). They say of the Schipka fragment: "Schaffhausen looked upon it as belonging to an ape-like giant in childhood ; but Virchow consiclered it the jaw of an adult with some dental complaint, but with nothing ape-like about it."

In regard to the skeleton of a lad of 16 , very carefully buried, found near Ie Moustier in SouthWestern France in 1901, Professor Branca says: "The skull had been broken in many places, which had been cemented together with green plastilin. 
But as parts of the skull were entirely wanting these were supplied through plastilin. Amongst other things, not only was the upper jawbone with the palate and the teeth broken off from the skull, but also their connection with the skull was destroyed, so that this also had to be supplied with plastilin.

"It stands to reason that it must be difficult, with such an absence of bony matter, to place the upper jaw at the right distance from the skull. One may easily in such a case either fasten the npper jaw too near to the skull; and then the skull must be less prognathous than it was naturally. Or one may fasten it too far from the skull. pushed too far forwards; and then the skull will be more prognathous than it was in life." (Fossil Man, p. 15.)

He adds that the reconstruction made the skull too prognathous and therefore more ape-like than it should have been.

In this connection the remarks of Dr. Duckworth should be noted (p. 10).

Professor Branca mentions a second reconstruction of this skull, made in Berlin, which he still did not consider satisfactory, and a third was madc afterwards.

The human remains found at Krapina in Croatia represented apparently a large number of individuals, but while as many as ten skulls were recognised, there was only one which it was at all possible to "reconstruct."

Dr. Otto Hamann writes in Die Abstammung des. Menschen: "Wilhelm Krause looked upon those remains very sceptically. He says: 'So few fragments of the Krapina skeletons lie before us, that the only similarity between the skulls consists in the formation of the frontal cavity, the height of the lower jaw, with long roots of teeth, and the 
retreating chin. But such specimens of frontal cavities are turning up yearly in our dissceting rooms, and are seldom wanting in our anatomical collections, and the same may be said as to the formation of the lower jaw'" (p. 37).

Professor Branca says: "It appears to me that it is impossible to decide whether all these ten skulls had really such a retreating brow and such a low roof of skull as to correspond to the Neanderthal type." (Fossil Man, p. 13.) He shows that Professor Gorjanovic-Kramberger spoke with caution on the subject: he was of opinion that two types of people were represented, while Professor Klaatsch brought forward a theory that some of the individuals were captives made by the Neanderthal people, and Dr. Duckworth is amused at the suggestion of a murderous conflict of two tribes at Krapina, which we owe, he says, to Professor Klaatsch's imagination.

Branca notes that while some of the skulls showed prominent eyebrow ridges, there was an absence of the prognathism which has been attributed to the skull of primitive man.

As regards the Gibraltar skull, which was found so long ago as 1848, practically nothing is known as to its surroundings at the time of its discovery. It was only in quite recent years that Professur Schwalbe, Professor Sollas, and others, came to the conclusion that it had characteristics that appeared to connect it with the Neanderthal race.

M. Mortillet, in Le Préhistoire does not include the Gibraltar skull in his list of Neanderthal remains (pp. 286, 295).

We may perhaps leave out of consideration the twelve teeth found at St. Brelade's, Jersey, shewing those peculiar features which stamp and distinguish the teeth of Neanderthal man; also the two teeth found at Taubach, which "although they do not 
show the typical Neanderthal characters, may very well have belonged to an individual of that race." But an American scientist considers the Taubach teeth to belong to a chimpanzee.

The skeleton of a woman found at La Quina docs not call for much remark, because, although there are prominent eye-brow ridges, the bones of the skull are not thick like those of Neanderthal man, and the brain capacity is that of the average nodern woman.

Of the two skeletons found at La Ferrassie in 1909 and 1910, the skull of the first was broken beyond repair. Of the second, all that we are told by Professor Keith is that it showed Neanderthal characters.

Of the skeleton found in a cave at La Chapelleaux-Saints in 1908, parts were missing, and the sikull was so broken that a reconstruction could only be carried out by taking parts of the La Ferrassie skeletons.

\section{The Heidelberg, or Mauer Jawbone.}

As regards the lower jaw-bone found at Mauer, near Heidelberg, in 1908, it is only necessary to add to what is said on pages 18 and 19 the following remarks of Professor Branca :-

"I am far from underestimating the importance of the Mauer lower jaw in regard to our knowledge of skulls of the lower type. But when we remember that (1) amongst the Eskimos of to-day, similar lower jaws, if not of quite such a low organisation, are found without the marks of that lower organisation being shown in the forehead and the skull; and that (2) we find something similar in the two lower diluvial skeletons from the Grotte des Enfants (Mentone), it follows that we should view with great caution isolated lower jaws if we are inclined to infer from them the inferiority of the whole skull. And that, all the more, as it is exactly forehead and 
roof of the skull (Schädelkalotte) which offer the very much more important marks of a lower organ. isation than do the lower jaw or other parts of the skull"' (Fossil Man, p. 21).

Of the two skeletons (of an old woman and a young man) from the Grotte des Enfants, Branca says: "Such skulls of the indeterminate type are of great importance on this account, that they expressly show us that, if we had found only the teeth and the lower jaw, we should have considered these people of the Neanderthal type, and if we had only found the forehead and the upper part of the skull, we should have taken them to belong to the higher type. Surely a notable example, which warns the enquirer to be very careful about imperfect fossil skulls" (pp. 11, 12).

\section{The Neanderthal Race.}

As regards the Neanderthal race generally, Mr. Marett says in his Anthropology: "Ape-like they doubtless are in their head-form up to a certain point, though almost all their separate features occur here and there amongst modern Australian natives. And yet they were men enough, had brains enough, to believe in a life after death. 'There is something to think about in that" (p. 79).

Further on he says: "Some specimens of Neanderthal man in sheer size of the brain cavity are said to give points to any of our modern poets and politicians"' (p. 87).

Professor Otto Hanann, in Die Abstammung des Menschen (p. 36), says that Spengel, in his Schädel vom Neandertaltypus (1875), spoke of the skulls of the Neanderthal type being often found amongst those of the European races, instancing some of Frisians in a collection of skulls at Göttingen, and he mentioned one particularly found in the island of Marken, in the Zuyder Zee. 
Dr. Hanann dwells upon the facts connected with the burial of the skeleton of the young man found at Iie Moustier, showing that there were clear proofs at that time of a belief in a life after death. He says that although we find skulls with a retreating brow, and more or less prominent eyebrows, and almost without a chin, we must guard ourselves from asserting that these are animal characteristics or ape-like formations, and he adds that Macnamara has shown in his Kraniologischer Bciceis über die. Stellung des Menschen in der Natur (Evidence from Craniology of the position of Man in Nature) that the skulls of Australians and Tasmanians have on the average a smaller capacity than those of the Neanderthal man.

(Wasmann says that the largest skull on record was that of a savage of New Britain, and was discovered by Professor Virchow.-Modern Biology, p. 50S.)

Dr. G. F. Wright, in Man and the Glacial Period, says: "Upon extending enquiries it was found that the Neanderthal type of skull is one which still has representatives in all nations; so that it is unsafe to infer that the individual was a representative of all the individuals living in his time. The skull of Bruce, the celebrated Scotch hero, was a close reproduction of the Neanderthal type, while according to Quatrefages, the skull of the Bishop of Toul in the fourth century even exaggerates some of the most striking features of the Neanderthal cranium. The forehead is still more receding, the vault more depressed"' (p. 276). (He apparently intends these remarks to apply to the Neanderthal man himself.)

\section{Environment of Neanderthal Man.}

Sont writers suggest that the special characteristics of the Neanderthal race may have been due to their environment and mode of life. 
Professor J. Ranke, in Der Mensch, says: "R. E. v. Baer has said that, according to some observations that have been made, life in the mountains appears to have an influence in changing the form of the skull ; it seems to make the skull shorter. But he acknowledges, just as myself, the difficulty of coming to a definite conclusion from such observations."

Ranke goes on to say that it would take many generations for such influence to make itself positively felt, and to turn dolichocephalic (long-headed) skulls into brachycephalic (short-headed) ones, and it would be a question, not so much of the actual altitude, as of the mountainous character of the place of abode, and he alludes to the effect of the continual holding up of the head incidental to mountain climbing.

In L'Homme Contemporain du Mammouth à Spy we read :-

"According to our compatriot, Lehon, the great thickness of the eyebrow projections would be caused by the mode of life itself of fossil man. Always on the qui-vive to discover animals whom he would so much have to fear, or whom he would seek to make his prey, the knitting of the brows, in developing the muscles of this part of the face, would also enlarge the tendinous attachments and the bony base, and give to his physiognomy a singularly ferocious aspect." (Lehon, L'homme fossil en Europe. Brussels, 1877, p. 58).

Professor Virchow, however, as regards those skulls supposed to be of the Neanderthal race which had been discovered in his time, believed their special characteristics to be due to disease. In his address at the International Congress of Prehistoric Archrology and Anthropology at Moscow in 1892 (which appeared in the Popular Science Monthly for January, 1893), he declared that "all men having 
a simian appearance are simply pathological variants," and this was several years after he had examined the Neanderthal man and the Spy skeletons, and, of course, he must have been well informed as to the skinl found in 1848 at Gibraltar. No man could be better qualified to give an opinion on such a subject. The Encyclopedia Britannica says: "He may, in fact, be called the father of modern pathology."

In the National Museum at Berne a catalogue of his medical and scientific treatises can be seen ; they number about 2,000.

But indeed Professor Keith, in his book, in speaking of the Piltdown skull, mentions a disease called acromegaly. He says: "In that particular disease or disturbance of growth, acromegaly, which somstimes attacks men or women, the jaws and the parts of the skull concerned in mastication are particularly liable to become overgrown. The growth of the jaws is also influenced during normal development by secretions or substances thrown into the circulating blood by such glands as the pituitary and thyroid"' (p. 466). May this, or some other disease, account for the abnornal features in the so-called Neanderthal race?

\section{What Evidence of Man's Evolution?}

WE are now in a position to consider the evidence as to the alleged animal descent of mankind aftorded by the fossil remains which have hitherto been discovered. While most of the modern English works which are likely to be seen by students, including the recent book of Professor Osborn, treat many of these as "missing links," Dr. Keith shows that the discoveries of the last ten or fifteen years of men quite of modern build who lived very near the same period prove that these cannot be "links" between modern man and the ape. As we have already seen, 
he therefure forms a new theory-viz., that Pithecanthropus, of Java, and Eoanthropus, of Piltdown, and then the Neanderthal race, were almost the terminating points of three lines of succession which branched off from the original animal stem at various times, and then a little later disappeared, leaving no descendants, while modern man is descendied from the Cromagnon and other races, which arose also from the original animal stem, but threw off all traces of the animal-that is, as far as their bodily frame was concerned-at a much earlier date, and hat atained to the human form of the present day at a time when the Neanderthal race at all events still retained its animal characteristics.

In the lists we have given from Dr. Kcith's book, about sixty places are mentioned where human remains have been discovered, besides a few others where only implements, supposed to have been used by man, have been found.

The remains at fourteen of these places, all of them on the Continent of Europe, are classed by Dr. Keith as belonging to the "Neanderthal race." 'Then there are the Pithecanthropus of Java and the Eoanthropus of Piltdown. The all-important point is, for the decision of the question as to the ancestry of mankind, whether these sixteen cases afford us evidence sufficient to lead us to accept the theory of an animal origin for the human race. In all the other cases the remains are acknowledged to have belonged to men of the type of those living in the present day.

As regards Pithecanthropus, we have the decided opinion of Professor Virchow, the foremost anthropologist of the day, and the one who had the fullest means of making a careful examination, that the remains were those of an ape.

As to Foanthropus, although Dr. Keith devotes the grenter part of his book to the subject, he does 
not come to any very definite conclusion, and an American scientific man now considers that the only part of the remains that appeared ape-like really belonged to an ape, and not to the Piltdown skull.

While this opinion is contested by Mr. Pycraft, he admits that the skull is less ape-like than that of many modern men, and its antiquity is questioned.

As to the Neanderthal race, there was the greatest doubt about the Neanderthal man himself until the Spy skeletons -were found, and the original reports as to the finding of these show how imperfect they were. Some parts were missing, which prevented "the important question of the facial prognathism of the Neanderthal race " being decided, and as the arms were broken they could not well be comipared with simian limbs. Then Professor Virchow pointed out a mistake in the reconstruction of the skull, which was admitted. As so much has been made, by Professor Cope and others, of the importance of the Spy remains, these points must not be forgotten.

We must also notice Professor Obermaier's opinion as to their geological age.

In the case of most of the other Neanderthal specimens there were serious difficulties attending the "reconstruction" of the remains. As to the Heidelberg jaw, which has been considered to be of so much importance, we must certainly listen to the warning of Professor Branca as to drawing any conclusion in regard to a skull merely from a jawbone.

It must be left to the.consideration of the reader, after carefully weighing the whole of the facts set forth in these pages, how far the fossil remains, which are so fully given us in Dr. Keith's book, go to prove, or render at all probable, the derivation of mankind from the animal world. 


\section{The Human Body.}

WE must now turn to another part of our subject and consider the characters in the body of man of the present day which are alleged to be proofs of his animal ancestry.

In his "Chapter of Conclusions" (p. 506), Professor Keith says: "All who have made a study of the human body are agreed that we must seek for man's origin in an ape-like ancestor." This is rather a sweeping statement.

Some years ago, before he had discovered that the "missing links" were not links at all, Dr. Keith published in the Home University Library a small book entitled The Human Body. In this book, the various organs in the body of man are compared with the corresponding organs in the anthropoid apes. (The references in the pages following are to this book.)

It is well to take note, before we pass on, of a statement in the opening chapter :- "For more than three centuries men have studied the structure of the human body, and yet to-day there is still much, very much, which we do not understand"' (p. 20).

On page 41 we read: "When we look more closely we see that every bone of man's body is present in the gorilla, they occupy exactly the same place in the skeleton; each bone shows the same leading features; the differences relate merely to proportion, size, and detail."

But we must put beside this a statement of Professor Huxley in his essay, On the Relation of Man to the Lower Amimals, which no doubt is equally true. Having referred to a misunderstanding as to the structural differences between man and the highest apes being small and insignificant, he says: "Let me take this opportunity of distinctly asserting on the contrary that they are great and significant; 
that every bone of a gorilla bears marks by which it might be distinguished from the corresponding bone of a man, and that, in the present creation, at any rate, no intermediate link bridges over the gulf between Homo and Troglodytes."

\section{The Muscles.}

SOME of the arguments in Dr. Keith's book are drawn from the fact that many of the muscles in the body of man correspond to muscles which are well developed in apes. Here we may compare what we read in Darwin's Descent of Man as to the muscles. His second chapter begins: "It is manifest that man is now subject to much variability. No two individuals of the same race are quite alike. . . The muscles are eminently variable: thus those of the foot were found by Prof. Turner not to be strictly alike in any two out of fifty bodies; and in some the deviations were considerable. He adds that the power of performing the appropriate movements must have been modified in accordance with the several deviations. Mr. J. Wood has recorded the occurrence of 295 muscular variations in thirtysix subjects, and in another set of the same number no less than 558 variations, those occurring on both sides of the body being only reckoned as one." In view of this variability it would seem extremely difficult to draw any very definite conclusions from a comparison of human muscles with those in the body of an ape. Probably simian muscles would be found quite as variable if a sufficient number of observations were made.

\section{The Human Eye.}

As regards the human eye, Professor Keith does not refer to the ape, but, taking what evolutionists consider to be vestigial organs, he briefly alludes to 
animals lower in the scale, such as the cat and the lizard. "Evidently," he says, "in the human ancestry, a third eye-lid had been present, such as can be seen in the eye of the cat. But allusion must be made to a very remarkable vestige of another eye, now completely buried beneath the great mass of our brain. Mention has been made of a bridge of tissue-the corpus callosum-which unites the two cerebral hemispheres. Underneath its posterior end is a small body no larger than a barley or wheat grain, known as the pineal gland. Connected with this vestigial body are remnants of optic nerves and optic ganglia. One has to go down the animal scale to the most primitive form of lizard-Sphenodon-to see this body assume the shape of an eye" (p. 213).

Sphenodon is a lizard-like animal, found in $\mathrm{New}$ Zealand.

A remark of Professor Keith in dealing with the subject is significant. He says : "It may seem to the reader that the short account which has been given of the development of the eye only makes its evolution more marvellous and mysterious. It must be remembered, however, that we are witnessing the result of a process which has been at work for millions of years. . . One cannot expect the anatomist to unravel in a few years that which has taken the life-time of a world to evolve" (p. 212).

In The Origin of Species (Chap. vi.) Darwin confessed his great difficulties in regard to the evolution of the eye. "To suppose that the eye with all its inimitable contrivances for adjusting the focus to different distances, for admitting different amounts of light, and for the correction of spherical and chromatic aberration, could have been formed by natural selection, seems, I freely confess, absurd in the highest degree." And in another place he says that the thought of this difficulty, even to the last, gave him a cold shiver. 
M. Henri Bergson, in his Creative Evolution, takes up this subject of the eye, and he instances the eye of a small shell fish, the Pecten. "Let us place side by side the eye of a vertebrate and that of a mollusc such as the common Pecten. We find the same essential parts in each, composed of analogous elements. The eye of the Pecten prescnts a retina, a cornea, a lens of cellular structure like our own. There is even that peculiar inversion of retinal elements, which is not met with, in general, in the retina of the invertebrates. Now the origin of molluscs may be a debated question, but, whatever opinion we hold, all are agreed that molluscs and vertebrates separated from their common parentstem long before the appearance of an eye so complex as that of the Pecten. Whence then the structural analogy?"' (p. 66).

Further on he says: "How could the same small variations, incalculable in number, have ever occurred in the same order on two independent lines of evolution, if they were purely accidental? And how could they have been preserved by selection and accumulated in both cases, the same in the same order, when each of them, taken separately, was of no use ?" (p. 68).

Again: "Supposing chance to have granted this favour once, can we admit that it repeats the selfsame favour in the course of the history of a species, so as to give rise, every time, all at once, to new complications marvellously regulated with reference to each other, and so related to former complications as to go further on in the same direction? How, especially, can we suppose that by a series of mere 'accidents' these sudden variations occur, the same, in the same order-involving in each case a perfect harmony of elements more and more numerous and complex-along two independent lines of evolution?"'(p. 70). 
In a long argument, occupying thirty-six pages, M. Bergson clearly demonstrates that the difficulty is a formidable one if either of the theories of evolution generally received is adopted: his own suggestion, that of an original "vital impulse," is not very clearly explained. Further allusion to M. Bergson's views as to evolution will be found later on in this book.

\section{The Blood of Man and Ape.}

PROFESSOR KEITH asserts that recent researches have proved that there is a blood relationship between man and the anthropoid apes. He says: "A special solution is prepared for testing the blood of each animal. We shall suppose that the solution prepared is for detecting human blood. When to this solution is added a fluid in which a strain of human blood has been dissolved, a cloudiness appears in the solution, and a precipitate appears in the test tube. No other blood except human will give the full precipitate. If a solution of dog's blood is added, there is no result. Professor Nuttall, however, found that a precipitate could be obtained with the blood of anthropoids, not so plentifully as is the case with human blood, but yet enough to show that in 'blood relationship ' man and the anthropoids stand very near together" (p. 53).

Professor Schwalbe, in the Darvin Centenary Yolume, asserts this in a stronger manner still:"We have in this not only a proof of the literal blood-relationship between man and apes, but the degree of relationship with the different main groups of apes can be determined beyond possibility of mistake" (p. 129).

If we turn to Professor Nuttall's book, Blood Immunity and Relationshib, we shall find that, far 
from saying that conclusions can be arrived at "beyond possibility of mistake," he devotes about twelve pages in the introduction to explaining the different circumstances which may in many cases make the results of such experiments inconclusive.

This subject was brought prominently before the public some years ago in a murder case, when an expert gave evidence as to blood-stains, and said that che blood must either have been human blood, or that of an anthropoid ape.

Although Professor Nuttall considers the evidence he obtained conclusive, he says: "In view of the crudity of our methods, it is not surprising if certain discrepancies may be encountered in the course of investigations conducted by biological inethods," and he adds: "My studies must be regarded in the light of a preliminary investigation" (p. 4).

\section{Sources of Error.}

PAGES 72 to 87 of Professor Nuttall's book are headed, "Sources of Error in Precipitin Tests," and the following remarks may be quoted-

"In the absence of more obvious sources of error . . . the use of what may be described as 'opalescent antisera' constitutes one of the gravest in using the test"' (p. 72).

"Tests in which concentrated sera are brought together and allowed to interact, as in the experiments of Friedenthal and others, are liable to lead to false conclusions" (p. 74).

"A small quantity of chloroform in a test serum? will frequently cause it to produce a considerable clouding, which may be a source of error"' (p. 76).

"I,ysol and lysoform both cause great turbidity when added to salt solution. . . . No method has been devised for getting rid of these effects. Consequently the presence of these substances, except in 
very small quantities, would render the test of doubtful value" (p. 78).

In speaking of the methods of other experimenters, he says: "'That the use of concentrated sera or dilutions constitutes a grave source of error when making tests with specific precipitating antisera, has already been pointed out'" (p. 150).

It may be added that Professor Nuttall gives a chart showing the Pithecanthropus as ancestral to man, and apparently considers that his researches tended to establish that relationship, but of course, when his book was written the discoveries which have led Professor Keith to abandon the "missing link" theory had not been made public.

Professor W. B. Scott, in his recent work, The Theory of Evolution (1917), says : "It must not be supposed that there is any exact mathematical ratio between the degrees of relationship indicated by the blood tests and those which are shown by anatomical and palæontological evidence. Any supposition of the kind would be immediately negatived by the contrast between the blood of mammals and that of birds. It could hardly be maintained that an ostrich and a parrot are more nearly allied than a wolf and a hyena, and yet that would be the inference from the blood tests. Like all other anatomical and physiological characters, the chemical composition of the blood is subject to change in the course of evolution, and these developmental changes do not keep equal pace in all parts of the organism"' (pp. 79, 80).

In Wasmann's Modern Biology (p. 456, et seq.), some account is given of the experiments of $\mathrm{Dr}$. Hans Friedenthal, Dr. Uhlenhuth, and others in Germany, but on page 503 Wasmann says: "I was very glad that Friedenthal himself took part in the discussion that followed my Berlin lectures in 1907, and declared that in using the word 'blood-relation- 
ship, he had never meant anything more than a blood resemblance in the chemico-physiological sense. It was a mistake on the part of writers on popular science to say that by blood-relationship he understood actual kinship, and he protested energetically against having such an idea imputed to him."

Professor Otto Hamann, in his book Die Abstammung des Menschen (The Descent of Man), quotes Dr. Gustav Wolff, who, in his Begründung der Abstammungslehre (Münich, 1907), speaks of the "interesting discovery recently made in regard to the blood of different animals," and says : "Injudicious fanatics announced with a great outcry that the blood-relationship of men with apes had now been proved. It is greatly to be regretted that these exceedingly important discoveries should be misused in this way. For the foundation of the theory of descent they really furnish nothing new in principle. . . . That the systematic agreement (between related animals) rests not only on morphological but also on physiological relationship corresponds to all that is already known. That the blood was to be an exception to this was not to be expected.

The manlike apes are those animals which in all points are most similar to man-hence the name, anthropoids. Can it astonish us if the blood is also similar? New conclusions can only be drawn from this by means of a quite unfair or weak-minded exchange of the ideas of 'similarity of blood' and 'blood-relationship.' The fact of this 'blood-relationship' is indeed highly interesting, and in fact very important, but for the foundation of the theory of descent it has no greater significance than that of every other fact of comparative biology' (p. 24).

Dr. Hamann refers also to the opinion of Professor $\mathrm{J}$. Bumüller in Die Entricklungstheorie und der Mensch, and of Professor Adloff in Das Gebiss des 
Menschen und der Anthropomorphen, who, he says, warn us not to overestimate the results of these interesting experiments. Both agree in the conviction that similar reactions of differcint blood sera are only so-called convergence appearances which are conditioned by outward circumstances, but do not depend upon common descent."

\section{Blood and Skeleton.}

BUT a new light appears to be thrown upon this question by a paragraph in Professor E. W. MacBride's Zoology: "It must seem strange to the ordinary reader to associate blood and skeleton. That they are closely associated is one of the curious and unexpected discoveries of scientific zoology. The simplest type of internal skeleton is a more or less firm secretion separating two layers of epithelium; such a skeleton is found in many simple polyp-like creatures which adhere to the sea-iveeds on ou1 coast. But the character of tlis 'basement menbrane,' as it is termed, varies indefinitely from a thin elastic membrane to a thick gelatinous semifluid mass such as is found in jelly-fish. When the skeleton takes on the latter form we find it in frec cells, which are capable of slow 'amneboid' movement. These cells have been budded off from the epithelial cells, but they are of quite a different character from these. They have the form of little lumps of protoplasm, from which finger-like or hairlike outgrowths radiate in all directions, and these outgrowths seem to be of the same nature as the outflows of cytoplasm by which simple animals like Amcba progress. But in many cases these cells appear to become stationary, and to join each other by the tips of their outgrowths so as to form a network. Along the sides of these connected growths there are deposited tough fibres, and in this way a 
network of fibres is produced. Now such a network of fibres is the fundamental basis of the construction of our own bones, tendons, and sinews. In our blood we have cells like those just described, viz., the celcbrated white corpuscles of which so much has been written in late years, but the 'skeletal substance' in which they move is the fluid of the blood. Nevertheless, even in this fluid there lies latent the power of forming fibres of essentially the same character as the fibres of tendon, and this power is called into activity in case of a wound when the outflowing blood is cxposed to the air" (pp. 28-30).

\section{The Vermiform Appendix.}

DiRwN's argument was that certain organs in the body of man were not only useless, but actually harmfirl. In The Descent of Man he says of the Appendix: "Not only is it useless, but it is sometimes the cause of death, of which fact I have lately heard two instances : this is due to small hard bodies, such as seeds, entering the passage and causing inflammation" ( $\mathrm{p} .30)$.

Professor IIniry Drmmmond, in The Ascent of Man, said: "There are undoubtedy cases where we know that certain vestigial structures are not only useless to man, but worse than useless. Coming under this category is perhaps the most striking of all the vestigial organs, that of the Vermiform Appendix of the Cæcum. Here is a structure which is not only of no use to man now, but is a veritable death-trap. . . . In the human subject, owing to its diminutive size, it can be of no use whatever, while it forms an easy receptacle for the lodgment of foreign bodies" (p. 121).

Dr. Keith does not take this position. He says (p. 49) : "Unfortunately, we do'not know the uses of the Appendix." Further on he says: "We seem 
to be dealing with a change in structure of exactly similar nature to those degenerative changes which we have already noted in the teeth, jaws, and throat. In their case it seemed most likely that their change in form is a result of diet, and it seems very probable that the same statement will yet be proved to be true in the case of the appendix" (p. 237). He goes on to speak of the colon, which Metchnikoff condemned, as well as the appendix, as useless :-

"Its main work in our ancestors consisted in the digestion of the cellulose or husk elements of grains and of fruit and vegetables. Our modern dietary has called upon it to act upon a dietary totally different to that for which it was evolved. Should we then blame the colon and call it a useless structure?" (p. 237).

\section{Alleged Vestigial Organs.}

DR. KEITH mentions some other organs of man's body, or traces of organs in the embryo which he treats as vestigial-that is, as traces of a reversion to a primitive mammalian position-e.g., the vestige of a former bone in the wrist of man (p. 196), the great toe of man (p. 128), the outer ear (p. 192), a rudiment of the azygos lobe at the base of the right lung (p. 83), the incipient tail (p. 81), and the hairs in certain parts of the body, which are attributed to "a very primitive scale-covered ancestry" (p. 206).

A very recent work by Professor J. Arthur Thomson, The Wonder of Life (a most charming book for the lover of Natural History), says : "Our own body is a veritable museum of relics--some (like the notochord) disappearing in embryonic life, others (like the Eustachian tube) persisting in greatly disguised form, others (like the third eyelid) remaining as dwindling vestiges, and others (like the vermiform appendix) not merely outliving their usefulness, but 
proving dangerous anachronisms" (p. 607). But afterwards he says: "It must be frankly admitted that many of the examples that used to be given of the re-assertion of long-lost ancestral characters were insufficiently criticised, and the list of so-called reversions has been remorselessly thinned by the more modern students of inheritance" (p. 610).

When we take up his book Heredity, we find that Professor Thomson has some strong criticisms on the tendency of biologists to treat some characteristics-whether of the human body, or of the bodies of animals-as reversions. He says :

"Supernumerary mammæ occasionally occur in human beings in both sexes. . Weismann says they are undoubtedly to be looked upon as reversions to extremely remote characters possessed by our lower mammalian forefathers. But it seems simpler to regard them as independent variations, comparable to many other abnormal multiplications of parts. They happen to suggest bygone conditions, but probably that is all we are warranted in saying. Polydactylism in man has been interpreted as a reversion to an ancestor with more than five digits, but this is illegitimate, for the so-called 'heptadactylous' ancestor is a pure myth.

"It occasionally happens that a particular part of the skin in man exhibits a mouse-like covering of close-set hair. To interpret this-a mere random variation-as a reversion, is credulous in the extreme.

"It ought not to be necessary to remark that the ancestor to whom the organism is supposed to revert must be real, not hypothetical" (Heredity, p. 130).

In regard to the malformation known as "harelip" "Dr. Keith says (p. 100) :-

"Some of the common malformations of the body appear to reproduce a condition which is only seen 
in fishes. 'The deformity known as 'hare-lip' is a case in point. . . Now the only adult vertebrate animais in which such a condition is seen to persist is the group of fishes to which the sharks and rays belong. In 'hare-lip,' then, we appear to see the reproduction of a condition known to occur only in gill-breathing vertebrates."

As to this, Professor Thomson says: "The abnormality known as 'hare-lip' is normal in rabbit and hare. . . But there is no reason to interpret the abnomality in man as a reversion: it is an arrest at a stage which is normally passed through : it is probably due simply to a lack of developmental vigour, or more simply-still to a lack of adequate nutrition" (Feredity', 1). 126).

A few pages later Professor Thomson says: "Some enthusiastic exponent; of the reversion theory have not scrupled to name or even invent the ancestor to whom the peculiarity in question is supposed to be a reversion, although evidence of the pedigree is wanting. And the terribly vicious circle is not unknown of arguing to a supposed ancestor from the supposed reversion, and then justifying the term 'reversion' by its resemblance to the supposed ancestor. Playing with biology can hardly go further than this! Moreover, the postulate of characiers remaining latent (save for occasicnal more or less hypothetical awakenings) for millions of years, is made as glibly as if it were just as conceivable as a throw-back to a great-grandfather" (p. 131).

Professor 'Thomson continues: "Professor Hanilton says: 'May we not entertain, as a possibility, that the gouty constitution, so called, is in part a reversion to some far-back ancestor?. . .'But our simple point is that the supposition of gouty tendencies lying latent in some form or other through 
millions of years taxes our imagination too severely. Such instances are almost sufficient to damn the reversion hypothesis altogether' (p. 131).

\section{Alleged Useless Organ.}

DR. KEITH makes an inportant admission: "It bas always been the custon to regard those organs whose function or uses are unknown as useless, rndinentary, or vestigial organs. As our knowledge of the body has increased, the list of useless organs has decreased" (1. 236).

Mr. Ii. S. Gooritich, in his Erolution (The People's Books), speaks stiil more strongly: "Some few years ago it might have been held-indeed it was held-that such organs in man as the thyroid gland, the pituitary gland, the suprarenal glands, and others, are useless structures, functionless vestigial remnants. They are now known to be of the greatest importance, altering the composition of the blood, or secreting substances essential for the regilation of the processes of metabolism. He would be a rash man indeed who wonld now assert that any part of the human body is useless"' (p. 68).

But, indeed, Darwin himself said in his Descent of Man: "I am convinced, from the light gained during the last few years, that very many structures which now appear to us useless will hereafter be proved to be usefu1"' (p. 92).

Probably all these things are met by the explaniation given by Professor Virchow that the human body has an animal organisation. In his article on The Problems of Anthropology in the Popular Science Monthly for January, 1893, he says: "The human organism, especially in the embryonic stage, is distinguished by many features that have been borrowed, not from the monkey only, bis also from other animals. . . Bearing in mind these 
observations, we have become more circumspect in our reasonings upon individual or racial analogies between man and animals; we certainly shall not forget that the human organisation is in its essentials an animal organism, and that the monstrosities which occasionally appear may be regarded as results of atavism; but we shall require more convincing arguments before we assume a near relationship of man with any definite animal. . . We are repulsed at every line of the assault upon the human question. All the researches undertaken with the aim of finding continuity in progressive development have been without result. There exists no proanthropos, no man-monkey, and the 'connecting link' remains a phantom."

\section{The Problem Involved.}

Ww may pause here for a monnent to consider what we are taught as to the theory of Evolution in Dr. Keith's two books, The Antiquity of Man and The Human Body.

We are asked to believe, first of all, that man and the anthropoid apes, and indeed all the present species of the ape-world, come from a common stem-from what we may perhaps call a race of ancestral apes-and that the separation of man from that common stem occurred some millions of years ago. Then we learn, especially from the discoveries made within the last ten or fifteen years, that what are quite probably the earliest fossil remains of man we have show the human body in the Pleistocene period, as far as its bony framework is concerned, quite what it is at the present day, or at all events with no more slight modification than we may trace from the time of the Norman conquest. Then we are told of various small organs or muscles in the body which resemble in some particulars those in the present anthropoid apes, and we are asked to 
take these as a proof that man is descended from the supposed ancestral apes, although, if such a race ever existed, we have no remains even of their bones, and cannot, of course, tell what the soft parts of their body may have been like.

But then, it is not explained why, if the skeleton of man's body had evolved into its present form so far back as the early Pleistocene period, any of his other organs should persist in their ape-like form up to the present time. These are vestiges, we are told, and reversions to an ancestral type. But why are there no reversions to such a tvpe in the bony skeleton of man of the present day ? It is true that a vestige of a small bone in the wrist of man is mentioned, but Dr. Keith tells us that a child has never been seen with an anthropoid foot (The Human Body, pp. 196, 107). The question is, can any satisfactory reason be given why such characteristics in our bodies as a peculiarity in the outer ear (p. 192), long and narrow nails (p. 206), a small muscle in the leg, called the psoas muscle (p. 91), which is not found in all men, and others, should have remained in the human body for so many thousands (Dr. Keith would say hundreds of thousands) of years after the evolution of the bony skeleton attained its completed form? This is a consideration that cannot be put aside.

\section{The Recapitulation Theory.}

WE will now consider the question of what is called the Recapitulation Theory, which is alluded to in Dr. Keith's book (The Human Body, ch. vii.).

Darwin and nearly all other evolutionists, but Hacckel especially, rely greatly on the evidence of Embryology. Nearly every animal begins life as a tiny cell - a little round speck which with the naked eye can barely be discerned as a very fine point. "So minute are some of these forms," says 
Professor Henry Drummond, "that if their oneroomed huts were arranged in a row, it would take 12,000 to form a strect a single inch in length. In their watery cities-for most of them are lake dwellers-a population of 800,000 million could be accommodated within a cubic inch" (The Ascent of Man. p. 88). The cmbryos of manmalia, of biris, lizards, and snakes," says Von Baer, "are in their earliest states exceedingly like one anotiner, both as a whole and in the mode of development of their parts, so much so, in fact, that we can often distinguish the embryos only by their size."

In the course of its life history the embryo undergoes various changes, and it is asserted that these changes are intimately related to its phylogenz; that is, the history of the descent of the animal from other living creatures in bygone ages of the world. This is called the Recapitulation Theory, and it has been treated as a very strong argument in favour of the theory of Evolution.

It is well known that Professor Drummond, in his Ascent of Man; tells us that the four clefts foutd. in every mammalian enbryo are relics of the gill-slits of fishes, that these slits in the fish's neck are still represented in the neck of man, and that he argnes from this that man has been evolved from fish-like ancestors. "It has long been a growing certainty," he says, "to Comparative Anatomy that the external and middle ear in man are simply a development, an improved edition, of the first gill-cleft and its surrounding parts" (p. 112).

Dr. Keith takes very much the same line. Ile says: "There appears on the neck of the embryo one of the most remarkable manifestations of a past stage of existence. On each side four grooves or depressions are formed. There can be no doubt that these represent the gill-slits of fishes" (The Iuman Body, p. 98). 


\section{Doubts as to the Theory.}

'Trufen are other biologists, however, who throw a great deal of doubt upon these statements.

In the Darwin Centenary volume, Darwin and Hodern Science, Professor A. Sidgwick, of Cannbridge, contributes a chapter on Aninal Embryology, and he decidedly opposes the theory that the embryo gives is a recapitulation of the ancestral history of an organisin. He says :-

"If it conld be shown . . . that ancient and extinct forms of life present features of structure now only found in embryos, we should have a body of facts of the greatest importance. But, as Huxley has shown, and as the whole course of palæontological and embryological investigation has demonstrated, no such statenient can be made . . So that the facts, as we know them, lend no support to the theory" (p. 174).

Then he turns to what is known as the Law of von Baer, that embryos of different species of animals of the same group are more alike than the adults. Of this he says: "Its truth has been seriously disputed. If it were true we should expect to find that the embryos of closely similar sipecies would be indistinguishable from one another, but this is notoriously not the case." Further on he says : "It is useless to say, as Weismann has stated, that 'it cannot be disputed that the vestiges of gill-arches and gill-clefts, which are peculiar to one stage of human ontogeny, give us every ground for concluding that we possessed fish-lite ancestors.' The question at issue is : Did the pharyngeal arches and ciefts of mammalian embryos ever discharge a branchial function in an adult ancestor of the mammalia?' We cannot, therefore, without begging the question at issue in the grossest manner, apply to 
them the terms 'gill-arches' and 'gill-clefts' (p. 175).

"After 50 years of research and close examination of the facts of embryology the recapitulation theory is still without satisfactory proof" (p. 176).

The article Embryology in the Encyclopadia Britannica by the same writer says:

"Now this explanation, which, it will be observed, can only be entertained on the assumption that the evolution theory is true, has been still further extended by embryologists in a remarkable and frequently unjustifiable manner, and has been applied to all embryonic processes, finally leading to the so-called recapitulation theory, which asserts that embryonic history is a shortened recapitulation of ancestral history, or, to use the language of modern zoology, that the ontogeny, or development of the individual, contains an abbreviated record of the phylogeny, or development of the race. A theory so important and far-reaching as this requires very careful examination. When we come to look for the facts upon which it is based, we find that they are non-existent, for the ancestors of all living animals are dead, and we have no means of knowing what they were like. It is true there are fossil remains of animals which have lived, but these are so imperfect as to be practically useless for the present requirements. . . Thus the explanation ordinarily given of the embryonic structures referred to is purely a deduction from the evolution theory. Indeed, it is even less than this, for all that can be said is something of this kind: If the evolution theory is true, then it is conceivable that the reason why the embryo of a bird passes through a stage in which its pharynx presents some resemblance to that of a fish is that a remote ancestor of the bird possessed a pharynx with lateral apertures such as are at present found in fishes" (Vol. ix. p. 322). 


\section{The Theory Strongly Criticised.}

\section{PROFESSOR V. L. KEILOGG Savs :}

"The proof that man is descended from a fish because he has gill-slits at one period in his individual development is not of the sort to rely on too confidently. The recapitulation theory of Fritz Müller and Haeckel is chiefly conspicuous now as a skeleton on which to hang innumerable exceptions." Again he says: "The recapitulation theory is mostly wrong ; and what is right in it is mostly so covered up by the wrong part, that few biologists longer have any confidence in discovering the right" (Darwinism To-day, pp. 18, 21).

M. Henri Bergson says : "It has been necessary to reject the almost classical theory of the specificity of embryonic gills" (Creative Evolution, p. 79).

Professor E. D. Cope, in his Primary Factors of Organic Evolution, while criticising the phylogenies (that is, the supposed ancestral histories of animais according to the theory of evolution) put forward by different naturalists, says: "Embryologists are especially apt to construct impossible phylogenies, as they are generally not systematists, and frequently not anatomists. An excellent illustration of an impossible phylogeny is that of the fishes published a few years ago by the embryologist, Dr. Beard" (p. 85).

In the same book (p. 205) he quotes the views of Mr. C. H. Hurst from Natural Science, 1893 :"My object now is to show that in neither case can a record of the variation at one stage of evolution be preserved in the ontogeny, much less can the ontogeny come to be a series of stages representing in proper chronological order some of the stages of adult structure which have been passed through in the course of evolution." Again Mr. Hurst says : "There is no parallelism between the ontogeny and 
the phylogeny of either a bird or any other animal whatever. A sceming parallelism will fall through when closely examined" (Primary Factors, D. 206).

Professor P. C. Mitchell, in the article Evolution in the Encyclopedia Britannica, says: "The general proposition as to a parallelism between individual and ancestral development is no doubt indisputable, but extended knowledge of the very different ontogenetic histories of closely allied forms has led us to a much fuller conception of the morie in which stages in embryonic and larval history have been modified in relation to their surronndings, and to a consequent reluctance to attach detailed importance to the embryological argument for evolution " (Vol. x., p. 35).

Professor F. W. Gamble, in The Animal World, says of the recapitulation theory: "The question is one of chormous difficulty, and the conficlent affrmative of twenty years ago is now rarely heard" ( $p$. 231). And he adds: "Man is at no time a fish, an amphibian, or a reptile, as it is somewhat crudely put' (p. 232).

Professor E. W. NacBricle, in his Zoology, says: "The recapitulatory interpretation of life-history was pursued with such fervour during the latter half of las century that it provoked a renction, and nany naturalists now speak slightingly of this thwry" (p. 76).

And Mr. Joseph McCabe, in The Princibles of livolution, has to make the adnission: "We must confess that this embryonic development is still a profound enigma" (p. 95).

Professor E. D. Cope also has to admit that "the records brought to light by embryologists are rery imperfect, and have to be carefully interpreted in order to furnish reliable evidence" (Primary Factors, p. 209). 
The Rev. E. Wasmann, in his Modern Biology, says: "Do facts warrant the assertion that the individual development of every creature is invariably an abridged recapitulation of the history of the race? No, they do not, for the exceptions to this rule are far more numerous than the instances of it"' (p. 449). And then he quotes several German naturalists in support of this view: Oskar Hertwig, E. Koken, His, W. von Bischof, Karl Vogt, and others.

It is essential to go into the subject rather fully because of the importance attached to it by writers who advocate the evolution of man from the animal.

Professor Weismann is one of the advocates of the Recapitulation Theory, and in the second volume of his book, The Evolution Theory, he quotes the opinions of Fritz Müller and Wiedersheim in its support, but at the same time he has to say: "I axtmit that these conclusions have sometimes been drawn with too great confidence" (p. 175), and again: "The ontogenetic evidence for phylogeny has been so much distorted by natural selection that is is probably the worst we have" (p. 251).

Wasmann says: "The resemblances between the human embryo and that of the other vertebrates are so superficial that His, W. von Bischof, and even Karl Vogt, and many other recent and thorough students of comparative embryology have protested against Haeckel's regarding these resemblances as phylogenetically significant identities" (Modern Biology, p. 455).

Many popular scientific books, written by men of distinction, have been brought out in the cheap libraries of recent years, and some of these do not give up the argument from recapitulation, though they have to make admissions. This is the case in Evolution by Professors P. Geddes and J. A. Thomson in the Home. University Library. In the chapter 
on Evidences of Evolution they give ten pages to the recapitulation doctrine, but they have to say: "It must also be frankly stated that we are apt to get into a vicious circle in arguing about recapitulation. We infer the pedigree from the development, and then say that the development recapitulates the pedigree"' (p. 58). And they go on in some measure to justify this.

Professor Keith, however, has to admit: "Now that the appearances of the embryo at all ages are known, the general feeling is one of disappointment; the human embryo at no stage is anthropoid in its appearance" (The Human Body, p. 95).

One cannot help remembering in this connection almost the closing words of Professor W. Bateson, in his essay in Darvin and Modern Science: "No one can survey the work of recent years without perceiving that evolutionary orthodoxy developed too fast, and that a great deal has got to come down" (p. 101).

\section{Differences between Man and Ape.}

WE may now glance at the opinions of some German scientific men.

Professor Otto Hamann's book, Die Abstammung des Menschen, is to a great extent a treatise on the structure of the human body as compared with that of the ape, and in it he shows by the testimony of several eminent scientific men, not the similarities between them, but the important differences which divide them one from the other. We give some extracts :-

"The anatomist Adloff says: If man in his distinctive features accords with the anthropoid apes, on the other hand he possesses many peculiarities belonging to him alone which differentiate him sharply and absolutely from them" (p. 25).

"Karl Ernst von Bacr, the great embryologist 
and anatomist, has been one of the first to take a stand against attempts made not to recognise a difference of form between men and apes. Aeby, Schaffhansen, and Ranke, the Nestor of anthropologists, have followed him, and recently, especially Bumüller, Stratz, and others, who have discussed the pros and cons in a circumstantial manner, while other anatomists have drawn attention to the differences of individual organs. Especially Adloff has compared the teeth of men and apes, and Aeby has made investigations as to the skull" (p. 26).

"The more or less upright position of the body of the anthropoid apes depends mechanically upon causes fundamentally different from those which apply in the human body. The head of the ape is hung and fastened laterally upon the top of the spinal column, and is held in its horizontal position when the body is half upright through elasticity and muscular strength ; the upright position is made possible through a special contrivance for support, for which special skeletal arrangements assist at the skull and at the spinal column near the neck. Their upright walk depends therefore for the most part upon muscular work. In the human body, on the contrary, the connection of the head with the spinal column is where the spinal marrow enters from the skull through the aperture at the back of the head into the spinal column" (p. 29).

"Bumüller, in his thorough treatise upon the thigh of man and of the ape, has laid stress upon the distinction, that man goes upon his feet without the use of his arms for support or balance; that body, thigh, and lower part of the leg lie as it were in a line, and that the axis of length takes a vertical position to the level ground. The ape, on the other hand, even the gibbon, cannot stand upright like the man. Even when he raises himself, the thigh 
and leg never stand in a line, but the thigh forms with the body and the lower part of the leg, and the latter again with the level ground, a greater or smaller angle. . . This reciprocal inclination of body and upper and lower part of the leg is exactly the type of the four-footed walk. As Bumuller shows, the principle of the four-footed walk is the nornial position of the ape. . . Were he to stretch his leg like a man, neither safe walking nor standing would be possible to him . . . On that account no ape can even temporarily walk upright, that is, like a man" (p. 31).

"But the greatest distinction appears in a comparison between the lower extremilies of men and apes. Although Blumenbach had already established these differences, Huxley asserted that the anes had, liza man, two hands in front and two feet behind

"Against this attempt at the denial of the differences in the biild of the extremities of men and apes first Lucae came forth, then Pagenstecher, Brin1, and Bischof, and above all R. F. von Baer.

"The differences may be put briefly as follows: With men the leg is exclusively the support of the body, and as such it exceeds in length and in weight the fore-limbs; with apes the arm is longer than the $1 e r$, and indeed the upper arm of the ape is proportionately shorter, the fore arm and the hand much longer than in man. The hand of the anthropoid ape never reaches the perfection of the human hand" (p. 32).

"Further differences between men and apes are shown in the teeth, as Adlof has shown in his book full of facts (Das Gebiss des Menschen und der Anthropomorphen)."

The result to which Adloff comes is that "the teeth of man can neither be derived from the anthro- 
poids, nor, on the other hand, can the dental system of the anthropoid apes have originated from man. The human jaw has a greater number of original characteristics to show, while the anthropoid teeth are more strongly developed, and farther removed from the original type through the strengthening of the gums," and he particularises certain protuberances due to the anthropoid mode of life. "Never," says Adloff, " can man have originated from a form with sich specialised pre-molars as the anthropoid apes."

The words of Stratz in his Naturgeschichte des Menschen (1904) are then quoted: "The present position of our palæontological knowledge shows us man in the diluviun in possession of his purely hunan form and of an already highly developed culture. But we must hold fast to this, that our whole knowledge is confined to a $\mathrm{few}$ renains of skeletons and stone implements.'

"This judgment, founded upon the latest discoreries, agrees remarkably with the words in which Huxley, although he supported the descent of man from the ape, summed up the knowledge of his day : 'In conclusion I must say that the fossil remains of man so far discovered lead us, as it seems to me, not remarkably nearer to that pithecoid form through which nresumably man has become what he is.'

"But there have not failed attempts to represent prehistoric, diluvial man as similar to the ape. That is not very circumspect, when we consider that, on account of the paucity of the human remains found, there are difficulties which so far are not to be overcome. On account of this paucity of material it is not always easy in individual cases to know which of the actually observed modifications are to be reckoned as race peculiarities, and which as norbid pathological appearances of nature, as Wilhelm 
Krause shows in what he has recently written upon the anatomy of the races of men" (p. 35).

As to the leg and foot of man, the following is from Holden's Human Osteology: "In proportion to the trunk, the lower limbs of nan are longer than in any other mammal, the kangaroo not excepted. Their great length prevents their being adapted for locomotion in any but the erect attitude. The femur has a long neck, set on to the shaft at a very open angle, so that the base of support is rendered still wider. The long shaft of the femur inclines inwards, bringing the weight well under the pelvis, which is obviously of great advantage in progression: and when the leg is extended, the femur can be brought into the same line with the tibia; thus the weight is transmitted vertically on to the horizontal plane of the kneejoint, while the articular surfaces of the bones are expanded, and give adequate extent of support.

"Contrast our long lower limbs with the short and bowed legs of the gorilla, chimpanzee, and orang utan. Watch attentively one of these three apes (the highest of the mammalia below man) in the act of walking; you will find that he supports himself alternately on the right and left knuckles as well as on his feet.

"The foot of man is broader, stronger, and larger in proportion to the size of the body than in any other animal; so that man can stand on one leg, which no other mammal can do" (p. 340).

\section{Man not from the Anthropoid.}

WE must understand that when the evolutionists endeavour to prove the affinity of the human race with the ape, they do not mean that any anthropoid ape of the present day was the ancestor of man.

Professor MacBride, in his Zoologv, says: "The quibbling objection that is sometimes raised, that 
our ancestors could not have been identical with any race of monkeys existing now, is entirely beside the point. Our ancestors may have so closely resembled a race of monkeys still living, that they would have been included in the same species" (p. 82).

Professor Metchnikoff, in The Nature of Man, says: "The data derived from embryology do not point to any one of the existing genera of monkeys as the ancestor of man. They lead us to infer, rather, that man and the anthropoid apes had a common origin."

Messrs. Geddes and Thomson, in their book, Evolution, say: "It is certain that he (man) did not arise from any of the known anthropoid apes (gorilla, chimpanzee, orang, and gibbon), but from a stock common to them and to him" (p. 101).

Professor Cope says: "It is highly probable that Homo is descended from some form of the anthropomorpha now extinct, and probably unknown at present, although we do not yet know all the characters of some extinct supposed Simiidae, of which fragments only remain to us" (Primary Factors, p. 158).

Professor Keith says: "So far as our knowledge goes the Miocene anthropoid apes offer us no form which can serve as a probable human ancestor . . . The evidence, so far as it goes, justifies us in presuming that the human and anthropoid lines of descent separated in pre-Miocene times " (Antiquity of Man, p. 507).

Professor Branca devotes a whole chapter of his book (chapter vi.) to "reasons against the possibility of the evolution of man from such anthropomorphic forms as the apes of the present day."

The article Evolution, in the Encyclopadia Britannica, says: "The existing apes are separated from the common ancestor by at least as large a number of generations as separate it from any of the forms of existing man" (Vol. x., p. 35). 


\section{Fossil Anthropoid Species.}

THIS supposed far-oft progenitor of man has never as yet been discovered, and indeed, when we enquire what is really known about the ape world in the past geological ages, it is somewhat surprising to find how very little it is.

Professor Branca gives the following list of the fossil remains of anthropoids, six European, two Asiatic, one African :-

Four species are only known through a single tooth :-

1. Neopithecus Brancoi Abel.

2. Dryopithecus Darwini Abel.

3. Gryphopithecus Suessi Abel.

4. Anthropodus de Lapouge.

One species through an mpper jaw with strongly marked teeth :-

5. Palæopithecus sivalensis Lyd (Asiatic).

One species is only known through a femur (thigh bone) :-

6. Pliohylobatus thenanus Dub.

(It is possible that this species should be omitted, as it is uncertain whether the thigh-bone may not belong to Dryopithecus; No. 8.)

One species is known only by a lower jam-bone with teeth :-

7. Propliopithecus Schlosser.

Two species are known through several upper and lower jaws and a number of loose teeth, and of one of them there is also a humerus:-

8. Dryopithecus Fontani Lartet. ('The humerus is short, thick, and large; according to Schwalbe, similar to that of the chimpanzee.)

9. Pliopithecus antiquus Gew. (A small form, approaching the Gibbon.)

One species is known through a femur, some teeth, and a skull :- 
10. Pithecanthropus erectus Dubois. (This is the Pithecanthropus (p. 29 et. seq.), which Branca classes as an ape.)

He mentions also a lower jaw with teeth, lately found in Africa, belonging to quite a small animal, and claimed by Schlosser as an anthropomorphic species.

Branca says: "Whoever reviews this poverty of the remains of fossil anthropomorpha so far known to us, even if he is a layman, will come to the conviction, without anything further, that there can be no question of their giving us proof of a continuons chain of ancestry of man."

There is no question of fossil forms from the American continent, because the anthropoid apes were confined to the old world.

The article, Primates, in the Encyclopedia Britannica, says that it has been suggested that Dryopithecus is closely related to man, but this idea is discountenanced by the great relative length of the muzzle and the small space for the tongue.

The Cambridge Natural History says of the Miocene apes: "Dryopithecus is more man-like than many others, and seems to have been as large as a chimpanzee. The incisors are human in their relatively small size. But it has been pointed out that the long and narrow symphysis of the lower jaw is a point of likeness to the Cercopithecidre." ('These do not belong to the family of the anthropoid apes.)

\section{Man's Supposed Ancestry.}

But if man has come from an animal ancestor in the far-off ages of the world, who in his turn camie from the original protoplasm, by what path has he travelled? Here the most eminent advocates of the theory are compelled to confess their difficulties. 
Messrs. Patrick Geddes and J. Arthur Thomson, in Evolution, in the Home University Library, say : "The uncertainties as to man's pedigree and antiquity are still great, and it is undeniably difficult to discover the factors in his emergence and ascent " (p. 102).

Professor Cope takes us back to the lemurs in his suggested ancestry for man. His conclusions are drawn to a great extent from an examination of the teeth. "The frequent presence of the tritubercular molar in man suggests the superior claim of the lemurs over the monkeys to the position of ancestor" (Primary Factors, p. 154).

Again: "The relation of this fact (as to the teeth of certain races) to phylogeny is to confirm Haeckel's hypothesis of the lemurine ancestry of man."

In another place he says: "I have expressed, and now maintain as a working hypothesis, that all the Anthropomorpha were descended from the Eocene lemuroids" (p. 157).

Even so, it seems that we are invited to look further back still. It appears that there are some "large-brained lemurs with a very anthropoid dentition (Anaptomorphiđæ) in our Eocene beds," and "Anaptomorphus is probably at the same time the ancestor of the Malaysian lemurine genus Tarsius, and M. Topinard remarks that Tarsius has as good claims to be regarded as ancestral to Homo as Anaptomorphus" (Primary Factors, p. 155).

But these speculations are a little too much for some more cautious biologists. Professor G. Schwalbe, in Darvin and Modern Science, says: "A theory which derives man directly from lower forms without regarding apes as transition types leads ad absurdum .. . To trace man's line of descent directly back to the old Eocene mammals, alongside of, but with no relation to these very 
sinilar forms, is to abandon the method of exact comparison ... The farther down we go the more does the ground slip from beneath our feet. Even the Lemuridæ show very numcrous divergent conditions, much more so the Eocene mammals (Credonta, Condylarthra), the chief resemblance of which to man consists in the possession of pentadactylous hands and feet! Thus the farther course of the line of descent disappears in the darkness of the ancestry of the mammals . . . If we regard man as directly derived from primitive forms very far back, we have no way of explaining the many points of agreement between him and the monkeys in general, and the anthropoid apes in particular. These must remain an inexplicable marvel " (p. 134).

Darwin himself also says, in his Descent of Man (p. 244): "In attempting to trace the genealogy of the mammalia, and therefore of man, lower down in the series, we become involved in greater and greater obscurity."

Professor St. George Mivart, who was one of Darwin's early critics and whose name is often mentioned in The Origin of Species, says: "If man and the orang are diverging descendants of a creature with certain cerebral characters, then that remote ancestor must also have had the wrist of the chimpanzee, the voice of a long-armed ape, the bladebone of the gorilla, the chin of the siamang, the skull-dome of an American ape, the ischium of a slender loris, the whiskers and beard of a saki, the liver and stomach of the gibbons, and the number of other characters in which the various several forms of higher or lower Primates respectively approximate to man.

"But to assert this is as much as to say that low down in the scale of Primates was an ancestral form so like man that it might well be called an homunculus; and we have the virtual pre-existence of 
man's body supposed, in order to account for the actual first appearance of that body as we know ita supposition manifestly absurd" (Lessons trom Nature, p. 176).

\section{Haeckel's Genealogical Tree.}

WE have seen that Professor Cope refers to Hacekel as an authority: we may, perhaps, before we leave the subject of the extraordinary speculations of some writers as to the genealogical tree of man, quote some paragraphs from Hacckel's Evolution of Man.

In chapter xx. of Haeckel's Evolution of Man, and in his Last Link, Haeckel gives his "hypothetical sketch of man's ancestry " in thirty stages, viz. :--

Earlier Series without Fossil Evidence.

1. Monera. Protist Ancestors.

2. Algaria.

3. L,obosa.

4. Infusoria.

5. Blastæades.

Invertebrate Metazoa Ancestors.

6. Gastreadies.

7. Platodes 1.

8. Platodes 2.

9. Provermalia. (Primitive worms.)

10. Frontonia.

11. Prochordonia.

Monorhina Ancestors (oldest vertebrates, without

12. Acrania 1. jain's or pairs of limbs).

13. Acrania 2.

14. Cyclostoma 1.

15. Cyclostoma 2. 
Later Ancestors, with Fossil, Evidence.

16. Selachii. (Primitive fishes.)

17. Ganoides. (Plated fishes.)

18. Dipneusta.

19. Amphibia.

20. Reptilia.

21. Monotrema.

22. Marsupialia.

23. Nallotheria.

24. Lemuravida. (Older lemurs.)

25. Lemurogona. (Later lemurs.)

26. Dysmopitheca (Western apes).

27. Cynopitheca (Dog-faced apes).

2S. Anthropoides. (Man-like apes.)

29. Pithecanthropi. (Ape-men, speechless.)

30. Homines. (Men, with speech.)

\section{Haeckel's Evidence.}

In chapter xix., Our Protisi Ancestors, Haeckel says :-

"I must point out at once, however, that the certainty of these evolutionary hypotheses, which rest on clear special dednctions, is not always equally strong."

"In any case we must distinguish between the absolute certainty of the general (inductive) theory of descent, and the relative certainty of special (deductive) evolutionary hypotheses."

"The special indication of stem-forms in detail will always be nore or less incomplete and hypothetical. This is quite natural. The evidence on which we build is imperfect, and always will be imperfect ; just as in comparative philology."

"The first of our documents, palæontology, is exceedingly incomplete. We know that all the fossils yet discovered are only an insignificant fraction of 
the plants and animals that have lived on our planet. For every single species that has been preserved for us in the rocks there are probably hundreds, perhaps thousands, of extinct species that have left no trace behind them. This extreme and very unfortunate incompleteness of the palæontological evidence, which cannot be pointed out too often, is easily explained."

"The second chief source of evidence, ontogeny, is not less incomplete. It is the most important source of all for special phylogeny; but it has great defects, and often fails us."

"The recapitulation of phylogeny by ontogeny is only fairly complete in a few cases, and is never wholly complete."

"Finally, the third and most valuable source of evidence, comparative anatomy, is also, unfortunately, very imperfect; for the simple reason that the whole of the living species of animals are a mere fraction of the vast population that has dwelt on our planet since the beginning of life."

"We must grant, however, that in the whole stem-history of the vertebrates the long stretch from the Gastræades and Platodes up to the oldest Chordonia remains by far the most obscure section."

We thus see the kind of evidence upon which Haeckel's speculations are built.

\section{Haeckel Criticised.}

PROFESSOR E. D. COPE appears to accept Haeckel's hypothesis to some ext nnt (Primary Factors, p. 154), but the following extracts show more clearly what is the general opinion of biologists on Haeckel's views :

Professor Kellogg says : "Biologists generally are agreed that Haeckel's daring speculations and reckless progress in advance of positions grounded on 
observed fact have been, in a way, always reprehensible and dangerous to the fair fame of biological science." (Darwinism To-day, p. 131.)

Messrs. Dewar and Finn say : "It is nothing short of a misfortune that Haeckel's History of Creation, which seems to be so widely read in England, should be built on a fallacious foundation. It seems to us that this work is calculated to mislead rather than to teach." (The Making of Species, p. 24.)

Sir J. W. Dawson, in The Story of the Earth and Man, says: "I saw not long ago a series of genealogies in geological time reduced to tabular form by that ingenious, but imaginative, physiologist, Haeckel. In one of these appeared the imaginary derivation of the higher plants from Algæ or sea-weeds. Nothing could more curiously contradict actual facts' (p. 79).

Dr. Russel Wallace says: "With Professor Haeckel's dislike of the dogmas of theologians . . many of us have the greatest sympathy ; but we have none with his unfounded dogmatism of combined negation and omniscience, and more especially when this assumption of superior knowledge seems to be put forward to conceal his real ignorance of the nature of life itself." (The World of Life, p. 7.)

(We must remember how very widely the English translations of Haeckel's works have been circulated, in a very cheap form, in this country, and largely amongst the working classes.)

And Professor W. B. Scott in his essay on The Palcontological Record, in Darzin and Modern Science, says: "The ludicrous discrepancies which often appear between the phylogenetic 'trees' of varions writers have cast an undue discredit upon the science, and have led many zoologists to ignore palæontology altogether as unworthy 
of serious attention.

What one writer postulates as almost axiomatic, anotner will reject as impossible and absurd"' (p. 189).

And then one of the foremost evolutionists, Professor August Weismann in The Evolutionary Theory, confesses how much has been mere guesswork: "In regard to the genealogical tree of organisms as a whole we can only make guesses, many of which are probable, but are never quite certain. The palæontological records which the earth's crust has preserved for us for all the ages are much too incomplete to admit of any certainty. Many natiralists, notably Ernst Haeckel, have done good service in this direction, for fron what we know of palæontology, embryology, and morphology, they have constructed genealogical trees of the different groups of organisms, which are intended to show us the actual succession of animal and plant forms. But, interesting as these attempts are, they cannot, for the most part, be anything more than guess-work" (Vol. ii., p. 388).

\section{From Ancestral Ape to Man.}

HAECKEL'S speculations refer largely to the question of the derivation of the Primates from the lower organisms in Nature.

But when we come to consider the descent of man from the hypothetical ape-like ancestor of Miocene times we may surely expect that the evolutionists will give us some theory as to the order in which man gained those special characteristics which differentiate him now from the ape world. But we search in vain for any definite pronouncement on this point. We may ask :-

When did man obtain his large brain?

When did he lose the hairy covering of his supposed ancestors? 
When did he acquire the gift of language?

When did he assume his erect posture?

When did he get his shorter upper limbs and longer lower limbs?

When did he get his flatten ed foot with the nonopposable great toe?

When was the human hand evolved?

When did the teeth of man become differentiated from those of the ape world?

Many such questions might be asked, and though, of course, no dates could be suggested, it would seem reasonable to expect that the evolutionists, who contend for the descent of man from some ape-like ancestor, should be prepared to give us some idea of the order in which these changes in man's structure could possibly have come.

The suggestions to be found in the works of Darwin, Drummond, Cope, Schwalbe, or Dr. Keith are very few and very vague indeed.

Darwin speaks of the loss of the hair-covering in man as possibly having some relation to a warm climate, but he prefers to attribute it to what he calls Sexual Selection, a theory which occupies a great part of his book, The Descent of Man.

Drummond says that "the discovery of language could not in the first instance have been responsible for the Evolution of Mind since man must have already had Mind enough to discover it " (Ascent of Man, p. 237).

Dr. Keith says that the foot of man was evolved before the brain (The Human Body, p. 77), but he argues this from the brain of Pithecanthropus, and when he wrote this he had evidently not come to the conclusion at which he afterwards arrived, that the remains found at Java could not possibly belong to a "missing link." $\mathrm{He}$ cites Professor Elliot Smith's opinion that " there is a correlation 
between the evolution of the human brain and the disappearance of a hairy covering"' (p. 204).

Dr. Duckworth, speaking of Pithecanthropus, says : "Whether the erect attitude or the characteristic brain-development was first obtained by man has been debated for many years. In this case, the evidence was taken to show that the assumption of the erect attitude came as a means of surmounting the crux of the situation. Thenceforth the upper limb was emancipated entirely from its locomotor functions. Upon this emancipation followed the liberation of jaws and mouth from their use as organs of prehension. Simultaneously, the mechanism whereby the head is attached to the neck and trunk became profoundly modified. This alteration gave to the brain an opportunity of growth and increase previously denied" (Prehistoric Man, p. 7).

But Dr. Duckworth goes on to say that the evidence of the human remains that have been found, and the embryonic evidence, point to an order exactly the reverse of this, and indicate the early acquisition of a large and presumably active brain.

Here we may notice what Dr. H. J. D. Astley says in his Prehistoric Archceology: "Man, feeble in his physical frame, not armed with tooth and claw like the beasts among which he dwelt, would soon have succumbed in the ceaseless war of Nature had it not been for his mental endowments" (p. 118).

Schwalbe shows that as bareness of skin could be no advantage to man, but rather a disadvantage, it could not have been brought about by natural selection (Darwin and Modern Science, p. 126).

As regards the evolution of the posture of man, Dr. Keith freely admits the difficulties. He says: "How then has man come by his remarkable posture of to-day? Many who have written about this 
phase of man's evolution have not fully realised the difficulty of the problem. They have assumed that at a far past stage of the world's history a form of monkey had abandoned a climbing life in the forests and become adapted to a life on the open ground.

The evolution of our posture is not nearly so simple a problem as those writers and thinkers have supposed .. The closer one studies the matter, the magnitude of the structural transformation required by a change of posture becomes more and more apparent. There is not a bone, muscle, joint, or organ in the whole human body but must have undergone a change during the evolution of our posture"' (The Human Body, pp. 70-73).

But Dr. Keith's solution of all such difficulties appears to be that the process occupied a period incalculably long-millions of years is an expression that he uses several times in speaking of the evolution of the great anthropoids, and if man and the anthropoids come from a common "humanoid" stem, as shown in the chart in The Antiquity of Man, his origin must have been earlier still.

\section{Arboreal Man.}

The most recent speculations as to the origin of the body of man are to be found in Arboreal Man, a volume containing lectures delivered by Professor F. Wood Jones in the Theatre of the Royal College of Surgeons in 1915 and 1916. These lectures are intended to demonstrate that man, as the supreme product of Evolution, could only have been developed from animals which had their homes and spent much of their lives in trees. He takes us back, in his suggested genealogy of man, to "a curious group of animals known as the Therapsida, which, presenting a blend of primitive reptilian and primitive mammalian characters, flourished in the "Triassic"' (p. 11). 
And further still. "It may seem a long way," he says, "to go back when attempting to unravel the influences of tree-climbing among the Primates, to appeal to the clambering activities of the water newt. And yet the anatomical condition of the limbs of man demands a shifting backward of the inquiry to some such stage as this" (p. 16).

His view is, that "the human stock has never been typically pronograde and four-footed " (p. 13).

Professor Wood Jones, in his preface, acknowledges his indebtedness to Professor Keith, but some of his arguments seem to controvert positions taken in The Human Body. In that work Professor Keith adduces organs or muscles which he considers vestigial as proof of man, in his evolution, having passed through a pronograde stage, and he says: "We have thus examined traces of a former pronograde posture in many parts of man's body, in the abdomen, thorax, neck, shoulder, arm, hand, foot, and leg" (p. 90), and then he mentions the small psoas muscle, which is often absent in man.

But the last paragraph of Arboreal Man says: "That there is an alternative to the all too common idea that a four-footed pronograde Mammal must have become upright in process of the making of mankind is, I think, obvious, and that this alternative is the gradual re-adjustment incidental to an arboreal life, I conceive to be certain."

In fact, we may say that a great part of Dr. Keith's book is taken up with showing that various muscles in man's body prove that he must have been descended from four-footed ancestors, while the whole argument in Arboreal Man is directed to prove that these ancestors must have spent their lives in climbing trees, keeping, for the greater part of the time, an upright posture. Professor Wood Jones does not 
explain to us whether the two views can be in any way reconciled.

From his saying: "To-day we have a bewildering complexity of genera and species of missing links" (p. 5), Professor Wood Jones also appears to be unaware of the conclusion come to in Dr. Keith's Antiquity of Man that the fossil remains that have so long been treated by biologists as "missing links" between ancestral ape and the modern man are not links at all.

With regard to the critical question whether a larger brain or the erect posture came first, Dr. Wood Jones says: "We are now confronted by a problem. Did the cerebral advance create the physical adaptations, or did the physical adaptations make possible a cerebral advance? It would seem, at first sight, that upon such a problem the argument might be as long sustained, and as futile, as that expended upon the priority of the hen or the egg" (p. 196). The conclusion he comes to is that the brain must have led the way in evolution, but that it could not effect much until there had been physical adaptations in the structure of the body.

\section{Sexual Selection.}

THESE changes must, of course, have included other things besides enlarged brain and change of posture. The loss of a hairy covering must have been one of them.

Darwin felt that it was so impossible to account for this by his theory of Natural Selection that he propounded the additional theory of Sexual Selection, and that subject occupies about two-thirds of his book The Descent of Man. His argument is that, although absence of hair was in some respects a disadvantage, it was considered an ornament. He says: "As the body in woman is less 
hairy than in man, and as this character is common to all races, we may conclude that it was our female semi-human ancestors who were first divested of hair, and that this occurred at an extremely remote period before the several races had diverged from a common stock. . . There is nothing surprising in a partial loss of hair having been esteemed as an ornament by our ape-like progenitors, for we have seen that innumerable strange characters have been thus esteemed by animals of all kinds, and have consequently been gained through sexual selection" (p. 917).

Dr. Wallace, in his Darwinism (chap. x.), criticises in some detail the views of Darwin as to Sexual Selection amongst animals, and comes to the conclusion that it could only have been an efficient cause of evolntion through the combats of the males for the possession of the females (see p. 282).

Goodrich says: "Almost always it is the males which compete for the females, either because they are more numerous, or because they are polygamous. This kind of selection takes place only among highly organised animals, and is almost entirely restricted to the vertebrates and arthropods (insects and spiders). It has been aptly called the struggle for wife as opposed to the struggle for life" (Evolution, p. 73).

Professor T. H. Morgan's Evolution and Adaptation (New York, 1903) has in chapter vi. an exhaustive attack on the theory of Sexual Selection, and Kellogg says that Professor, Gustav Wolff (Beiträge zur Kritik der Darwinschen Lehre) "looks on the theory of Sexual Selection as wholly discredited." (Darwinism To-day, p. 125.)

Professor W. B. Scott says: "Modern disciples of Darwin reject this factor (effects of use and dis- 
use), and attribute little importance to sexual selection" (The Theory of Evolution, p. 20).

\section{Difficulties as to Human Evolution.}

WH must remember the foundation principle of the theory of evolution as propounded by Darwin: "Natural Selection acts only by the preservation and accumulation of small inherited modifications, each profitable to the preserved being" (Origin of Species, chap. iv.). Now suppose one individual of the assumed ancestral ape-like race to have been born with a larger brain than usual, or with a foot adapted for walking instead of climbing, there would, of course, be danger of this special characteristic being lost in succeeding generations by interbreeding with normal individuals. Dr. Wallace mentions the "law of recession towards mediocrity," which means that "whenever parents deviate considerably from the average of the population of which they form a part, their offspring will tend to return towards the average." (World of Life, p. 103.)

But he deals with the difficulty (when spcaking of the evolution of species in general) by assuming that the number of varying individuals would be "counted by millions." (World of Life, p. 257.)

It is really very extraordinary, after all that has been written on the evolution of man from an animal stem, that we are left so entirely without any clear suggestions as to how modern man should have been evolved from the hypothetical ancestral ape family. It is perfectly clear that, if such evolution ever took place, it must have been by many stages, and we ask how, in accordance with the principles laid down by Darwin in the Origin of Species, it could possibly have occurred.

Professor Kellogg quotes the following from 
Professor E. D. Cope's The Energy of Evolution in the American Naturalist for 1894 :

"In order that a variation of structure shall survive, it is necessary that it shall appear simultaneously in two individuals of opposite sex. But if the chance of its appearing in one individual is very small, the chance of its appearing in two individuals is very much smalier. But even this concurrence of chances would not be sufficient to secure its survival, since it would immediately be bred out by the immensely preponderant number of individuals which should not possess the variation... In order to secure the survival of a new characterthat is, of a new type of organism-it is necessary that the variation should appear in a large number of individuals coincidentally and successively. It is excecdingly probable that this is what has occurred in past geologic ages. We are thus led to look for a cause which affects equally many individuals at the same time, and continuously" (Darwinism To-day, p. 185).

\section{Dr. Wallace's Suggestions.}

DR. WALIACE, in his Darwinism, in comparing man with the various species of anthropoid apes (the orangs, the chimpanzees, the gorillas, and the gibbons) shows that "man has little special affinity for any one rather than another species, while he differs from them all in several important characters in whicl they agree with each other" (p. 455). From this he argues that man "must have diverged from the common ancestral form before the existing types of anthropoid apes had diverged from each other," and this took place, he says, in the Miocene period.

From various considerations, Dr. Wallace then concludes that man acquired his brain, and his erect 
posture and free hands, at a comparatively early period, and these were the characteristics which gave him his superiority over other mammals, and his "mental development leading him to the use of fire, of tools, of clothing, of improved dwellings, of nets and snares, and of agriculture," he was started on the line of development which has led to the conquest of the world. But then he shows further that man must have increased rapidly, and spread widely. "A large population," he says, "spread over an extensive area is also needed to supply an adequate number of brain variations for man's progressive improvement."

Dr. Wallace then discusses the place of man's origin. "We can hardly suppose," he says, "that he originated in a forest region, where fruits to be obtained by climbing are the chief vegetable food. It is more probable that he began his existence on the open plains or high plateaux of the temperate or sub-tropical zone, where the seeds of indigenous cereals and numerous herbivora, rodents, and gamebirds, with fishes and molluscs in the lakes, rivers, and seas supplied him with an abundance of varied food." Then he says: "We are restricted to some portion of the Eastern Hemisphere, where alone the anthropoid apes exist, or have apparently ever existed," and he excludes Africa because it is known to have been separated from the northern continent in early tertiary times, so that only the great Euro-Asiatic continent remains (pp. 459, 460).

\section{What the Supposed Evolution would Involve.}

Turs sketch, by one of our ablest writers, of what, on the theory of man's original evolution, must most probably have happened, passes over some serious difficulties, and leaves some important questions to be answered. 
We have seen from all that has gone before that, according to the recognised principles on which the general theory of evolution is based, for the development of man from an ancestral ape-like animal in those far-off ages of the world, certain conditions would have been necessary :-

1. 'There must have been a large number of changes, especially in size of brain and in posture of body, occupying a vast period of time.

2. The first change, and each subsequent chan $x$, must have occurred in a large number of individuals at about the same time.

3. There must have been some cause that would in each case in some way isolate the individuals of the new type from those of the old type, so as to prevent the advantage gained being lost by interbreeding with the old type.

It seems impossible to imagine any cause which could, even for once, have brought about alterations of brain or posture in a number of individuals simultaneously, or any cause which could have accounted for the necessary isolation of such individuals, and it appears all the more impossible when we think of the large number of changes that must have occurred. It is admitted that the changes must have occupied a vast period of time, and this raises the further difficulty as to how a vast number of beings, half-animal and half-human, could have subsisted for ages in such a condition. We know the environment suitable for the ape world, and we know the environment suitable to the human race, but how can we imagine a series of environments, differing from time to time so as to be suitable for each stage of progress from ancestral ape to man? And, incidentally, we may a!so ask, how could it have happened that at each stage there was a step in adrance and not a step backward? 
It is most certainly the fact that no writer on evolution has dealt with these practical difficulties of the question. We do not ask the evolutionists to tell us what actually did occur, but we may fairly ask them to imagine-and some are not deficient in imagination - what possibly could have occurred to change an ancestor of the apes into a man.

When we consider the causes assigned by Darwin for the evolution of species generally, we must recognise that some of them do not quite apply to the question of the evolution of man.

The enormotis and rapid multiplication of many species of animals, causing necessarily a struggle for existence, is one of the chief facts that Darwin relied upon for his theory of Natural Selection. But that argument does not apply to the ape-tworld. As Dr. Wood Jones tells us in chapter xxi. of Arboreal $M$ in, arboreal animals tend to have small families, and among all monkeys one offspring at a birth is the general rule. "Helpless offspring, in large numbers," "he says, "may be managed and cared for in some safe terrestrial nursery, but up a tree, even were large numbers of such offspring produced, it is doubtul if many would survive."

Then one cause assigned for the evolution of species in past ages, the physical changes which involved the separation of what are now islands from the adjoining continents, would hardly apply to the ape-world, which had its home in the forest regions.

We may certainly suppose it possible that in a time of drought, or through forest fires, some colony of the ancestral apes may have been driven from their forest homes into the open plains, but would they not have perished? Or, if some had survived, would it not be those who could find food most easily? It may, perhaps, be said that any who had happened to be born with a larger brain might be 
more expert in finding food. But Professor Keith has shown us that the mere fact of such animals being driven by necessity from the forest regions to the plains could not of itself bring about that "complete revolution in the organization of the body" (The Human Body, p. 71) which would be demanded by a change to the upright posture.

\section{Dr. Wallace's Reply to Spencer.}

WE notice that Dr. Wallace considers it esscintial to suppose that there was a large population spread over an extensive area to give the adequate number of brain variations to account for the change of ape to man. In The World of Life he says, in reply to a difficulty brought forward by Herbert Spencer in regard to the evolution of species in general, that Spencer showed "that every variation, to be of any use to a species, requires a number of concurrent variations, often in different parts of the body, " and these could not be left to chance. Dr. Wallace's reply is: "The argument is entirely fallacious, because it is founded on the tacit assumption that the number of varying individuals is very small, and that the amount of coincident variation is both small and rare. . . All these assumptions are the very reverse of the known facts. The number of individuals in any dominant species (and it is only these which become modified into new species) is to be counted by millions. . . Again it has been shown that the number of coincident rariations are very great." (World of Life, p. 257.)

It is rather puzzling to read after this the following statement in the Presidential Address of Professor William Bateson at the meeting of the British Association in Melbourne in August, 1914: "Modern research lends not the smallest encour. agement or sanction to the view that gradual evo- 
lution occurs by the transformation of masses of individuals, though that fancy has fixed itself on popular imagination."

And, let us add, although the principle is relied upon by one of the greatest exponents of Darwinian evolution as a reply to one of the chief acknowledged difficulties of the theory.

\section{The Imperfection of the Geological Record.}

DR. WAILACE quite admits that when he speaks of the necessity of a large population spread over an extensive area being needed to supply the means for man's progressive improvement, this "renders it the more difficult to account for the complete absence of humall or pre-human remains in all those deposits which have furnished, in such rich abundance, the remains of other land animals" (Darwinism, p. 458). He says: "It seems impossible but that ample remains of Miocene and Pliocene man do remain buried in the most recent layers of the earth's crust, and that more extended research, or some fortunate discovery, will some day bring them to light"' (p. 459).

This was one of Darwin's great difficulties, and he meets it in chap. $\mathrm{x}$. of The Origin of Species, which is taken up with an argument drawn from the imperfection of the geological record. This argument comes forward again and again in his works, and in those of other writers. They all impress us with the fact that the geological strata convey to us only a small part of the past history of the earth.

Darwin shows that, if the evolution theory is true, the number of intermediate varieties which have formerly existed must be truly enormous. "Why, then," he asks, "is not every geological 
formation full of such intermediate links? Geology does not reveal any such finely-graduated organic chain." His answer is, the extreme imperfection of the geological record.

Now it will be observed that this is an argument not founded on facts, but on the absence of facts.

We can understand a man saying: "I am quite convinced that I am heir to such an estate, or to such a title, but unfortunately the imperfection of the old parish registers makes it impossible for me to prove it." Or a litigant may say : "I am certain that I could have proved my case up to the hilt, only, unhappily, the witnesses I should have brought forward are dead." In either case the proof is wanting; and we must mnderstand that this is exactly so as regards the geological record. But the evolutionist writers speak of this imperfect geological record as if this were in itself a proof-they simply assume that all the missing links which their theory requires must be there, if only we could search all the geological strata exhaustively.

Dr. Russel Wallace says : "All evolutionists are satisfied that the common ancestor of man and the anthropoid apes must date back to the Miocene, if not to the Eocene period, so that the real inystery is, not that the works or remains of ancestral man are found throughout the Pleistocene period, but that they are not also found throughout the Pliocene, and in some Miocene deposits. There is not, as often assumed, one 'missing link' to be discovcred, but at least a score such links, adequately to fill the gap between man and apes; and their nonriscovery is now one of the strongest proofs of the imperfection of the geological record." (World of Life, p. 247.)

Is not this rather an astonishing conclusion? Might we not certainly just as reasonably say that 
it is one of the strongest proofs that such "missing links" never existed? And especially so as Dr. Viallace admits in another of his works that certain linited portions of the geologičal record are fairly complete-as, for example, the various Miocene deposits of India, Europe, and North America (I)ar. winism, p. 380).

Messrs. Thomson and Geddes say that the geological record is not so hopelessly incomplete as Darwin believed it to be. They quote the opinion of "a living palæontologist of high achievement," Professor W. B. Scott, of Princeton: "Since The Origin of Species was written our knowledge of that record has been enormously extended, and we now possess, no complete volumes, it is true, but some remarkably full and illuminating chapters." (Evolution, p. 39.)

Professor Scott goes on to claim that in proportion to the completeness of the record its testimony to the truth of evolution is increased, but, however this may be, any argument from the imperfection of the record is weakened, and Darwin's question returns with added force: "Where are the intermediate links?"

Sir Charles Lyell, in The Antiquity of Man, says : "It is naturally a matter of no small surprise that, after we have collected many hundred flint implements (including knives, many thousands) not a single human bone has yet been met with in the old alluvial sand and gravel of the Somme.

Yet in these same formations there is no want of mammalia belonging to extinct and living species. Yet bones of man found in ancient battlefields were not more decayed than those of horses" (p. 190).

When Dr. Wallace speaks of a score of missing links, is it not a very small estimate when we think of the various adjustments that would have been 
necessary in changing from the ape-like ancestor to modern man, and of the "millions of years" that Dr. Keith evidently thinks necessary for the process? Would it not be more reasonable to suggest the need of a hundred such links, or even of a thousand?

\section{Unsolved Problems.}

IN his remarks on the Geological Antiquity of Man, Dr. Wallace adds: "It remains an unsolved problem why no traces of the long line of man's ancestors, back to the remote period when he first branched off from the pithecoid type, have yet been discovered" (Darwinism, p. 456).

But is this the only "unsolved problem "which this theory of man's animal origin creates? If it is astonishing that we have no fossil remains of man in his various stages of evolution from the animal stem, is it not an equally difficult question why we have not at present, on some part of the globe, rengresentatives of the half-human beings, in different stages of progress, which must according to the theory, have been at one time alive on the earth? If there was a common ancestor of all the present ape-world and man, why have we the four kinds of anthropoid apes, and the many kinds of monkeys, all living in the world at present, and why have all the representatives of the "humanoid" stem, as it is called, in its different stages, disappeared entirely? What possible cause can be assigned for the disappearance of all that did not attain to the form and stature of modern man? Did "Homo," when he had at last arrived on the scene, organise a general massacre of all the semi-human beings to be found in the world? Or were they all destroyed by the Flood?

The plain fact is, that if we are to adopt the 
theory, we must treat as facts a very large number of suppositions which are highly improbable, and for all of them to be true would be an impossibility. We must believe that in the Miocene age, or before it, there existed a race of ape-like animals of which not a single trace has been found amongst the fossils that have been discovered. Then we must believe that some of these were born with an abnormally large brain, and, although no possible cause can be assigned, a very considerable number of them about the same time. Then we must suppose that some circumstances arose by which these individuals were isolated from the rest of the ancestral apes. Further, we must imagine that the same thing must have happened in regard to some variation of structure tending towards the human form. Then we must conclude that this process was repeated many times, sometimes in enlargement of the brain, sometimes in modification of structure, the two processes perhaps occurring alternately. Again, we have to suppose such alterations from time to time in the environment- the climate, the food available, the conditions generally - as would enable the animals of the new type, as each change occurred, to live and reproduce their kind. And then, as we have séen, we must imagine some cause to account for the disappearance from the earth, on each occasion of the introduction of an improved type, of the remaining animals of the old type, leaving no descendants.

In regard to his theory as to Neanderthal man, Professor Keith admits that " the most marvellous aspect of the problem raised by the recognition of Neanderthal man as a distinct type is his apparently sudiden disappearance" (Antiquity of Man, p. 135).

And Professor Osborn says: "The most sudden racial change we know of in the whole prehistory 
of Western Europe is the disappearance of the Neanderthal race at the close of the Mousterian culture stage, which was the latest industrial period of Lower Palreolithic time. . . . So far as we know at present, the Neanderthals were, entirely eliminated" (Men of the Old Stone Age, p. 257).

Then how much more marvellous the disappearance of all the "missing links" from ancestral ape to modern man! Dr. Wallace admits a score such links, but surely we can hardly think of fewer than fifty or a hundred, or even more.

Professor August Weismann, in his work, The licolutionary Theory, in speaking generally of the cvolution of higher forms of animals from lower forms, says: "Thus higher types branched off from the lower from time to time, although the parent type did not necessarily disappear: indeed, it could not have disappeared as long as the conditions of its life endured" (Vol. ii., p. 379).

Professor Guenther says, in Darzin and the Problems of Life, in speaking of the Steinheim snails : "If a species was entirely rooted out there must have been some sudden accident" (p. 125).

It is clear therefore that the theory of Evolution, as generally understood, demands that if we are to suppose the disappearance of any type of animal that has ever existed, some cause for its extermination should be suggested.

\section{The Spiritual Nature of Man.}

We have said nothing, so far, as to the intellectual, moral, or spiritual nature of man.

Dr. Wallace, in the last chapter of his Darwinism, reviews the facts connected with the Mathematical, Musical, and Artistic faculties of inan, and comes to the conclusion that it is impossible that these and 
others that beiong to the same class can have been developed under the law of Natural Selection (pp. $464-475)$.

He goes on to say that "there are at least three stages in the development of the organic world when some new cause or power must necessarily have come into action."

"The first stage is the change from inorganic to organic, when the earliest vegetable cell, or the living protoplasm out of which it arose, first apneared.'

"The next stage is still more marvellous, still more completely beyond all possibility of explanation by matter, its laws and forces. It is the introduction of sensation or consciousness, constituting the fundamental distinction between the animal and vegetable kingdoms."

"The third stage is, as we have seen, the existence in man of a number of his most characteristic and noblest faculties, those which raise him furthest above the brutes, and open up possibilities of almost indefinite advancement."

"These three distinct stages of progress from the inorganic world of matter and motion up to man, point clearly to an unseen universe- to a world of spirit, to which the world of matter is altngether subordinate."

The closing words of this book of Dr. Wallace's are :

"We thus find that the Darwinian theory, even when carried out to its extreme logical conclusion, not only does not oppose, but lends a decided support to, a belief in the spiritual nature of man. It shows us how man's body may have been developed from that of a lower animal form under the law of natural selection ; but it also teaches us that we possess intellectual and moral faculties which could not 
have been so developed, but must have had another origin; and for this origin we can only find an adequate cause in the unseen universe of Spirit."

I have seen no answer to these arguments of Dr. Wallace in other books on Evolution, and indeed they cannot be answered. It was the works of Mr. G. J. Romanes-Mental Evolution in Animals and Mental Evolution in Man (1888), which most strongly advocated the essential similarity of the reasoning processes in some animals and in man, and thus supported the doctrine of the evolution of the mental and moral nature of man. Mr. Romanes published some books which showed an antagonism to orthodox Christianity, but his last book Thoughts on Religion, written just before his death, was of an entirely opposite character, and gave evidence of a spiritual change in this distinguished man. With reference to a doubt that was thrown upon his mental health at the time of writing this work, Dr. BurdonSanderson, in his obituary notice, written for the Royal Society, testified that to the end he preserved not only his mental vigour, but also his interest in scientific pursuits (see Times Literary Supplement, 21st and 28th Dec., 1916, pp. 625, 637).

It would be beyond the scope of this book to go into the arguments that have been used for and against the evolution of the mind and soul of man. Indeed, it is hard to see, if a man's own inner consciousness does not teach him that his intellectual and moral and spiritual nature can never have been derived by descent from the brute, how any reasoning would convince him.

Nearly all the more recent books on Evolution say very little about its application to man, and hardly mention his moral and spiritual nature. Speaking generally, they look upon evolution as a principle of the widest application, and make no exception as 
to man. These works usually assume that evolution has been already proved, and they are almost entirely occupied with discussing the method by which it has come about, on which point they differ widely. They say there is no question as to the Fact of Evolution ; the only ancertainty is as to the How.

\section{Opinions of German Writers.}

Professor G. Schirat,re says, in the introduction to his work on the early history of man (Vorgeschichte des Menschen, 1904): "Probably in no department of natural science is the attempt to draw general conclusions from a number of facts more liable to be influenced by the subjective disposition of the student than in the early history of man. On this subject it often happens that, upon a few facts, theories are based, which are stated with so much conviction as easily to lead those who have no special knowledge of the subject to regard them as assured scientific certainties."

Professor Schwalbe is a foremost evolutionist, and is one of the writers in Damein and Modern Science.

In the closing chapter of Professor Otto Hamann's Die Abstammung des Menschen (The Descent of Man), he says: "As long as Darwinism, that is, the Evolutionary theory in the Darwinian sense, and the Natural Selection theory, exclusively prevailed, as long as the endeavour was to set man down as low as possible, while the animal could not be placed high enough, thought was, as it were, kept in fetters, and only the one idea could be seized, that man must of a necessity have arisen from ape-like progenitors. It needed a long time of development until, at length, convinced by the facts, one saw that the mode of the formation and origin of man must have been quite a different one." After a reference to the views of investigators such as Klaatsch, Adloff, Stratz, Hubrecht, 
and others, he says: "But the picture which they give us must necessarily be a partial one when they only take the body of man into consideration. The modern anatomist only takes the body into account; he ignores the connection between the origin of man's bodily form and his spiritual being. He has still not comprehended that a true anthropology should treat of the connection between the natural descent of man and his spiritual superiority.

"The remains of man which have come down to us from the Diluvial period or the Pliocene period show us men, like we ourselves are, and not apes. Man, as we find him in the Diluvium, was in possession of a highly developed culture; he believed in the survival of the soul after death, as we must conclude from the burial of Mousterian man. From an unprejudiced investigation it is now irrefutably established that this prehistoric man was in possession of a distinctly human stature, and that, as Ranke puts it, he displayed the starting point of a further development, but not the lower animal form. . I I must expressly lay down here, that for one who only wishes to consider the facts, at one stroke the MAN is there (p. 54).

"But to those who incline to hold the evolution of the animal world in general and of man, it is indispensably necessary to take the position of the opinions which Klaatsch and others have expressed. But we must always remain conscious that in this we enter a region of pure speculation. If we accept the views of Snell, Klaatsch, and Stratz, that the forefathers of man are to be sought for amongst those animals of palæeolithic times, only traces of which have been preserved to us, this opinion appears somewhat strange to those who feel that creatures who carry in them the germ of a great 
future inust necessarily in their outward appearance be separated by a great gulf from all other beings. . . It was exactly this demand that Fechner put forward, when, one of the few of his time, he opposed the evolutionary theory of Darwin, so far as regards man (Einige Idecn zur Schöpfungs-und Entwicklungsgeschichte der Organismen, 1873). May the similarity of the ancestors of man with those of the apes be as great as it may, a common ancestry (Ebenbürtigkeit) with the apes is not to be acknowledged" (The Descent of Man, p. 55).

Dr. J. H. F. Kohlbrugge published at Stuttgart, in 1908, Die morphologische Abstammung des Menschen (The morphological descent of man). In this work he reviews the facts and opinions as to the origin of the body of man to be found in about 300 books or articles written by about 100 different authors: German, French, English, American, Dutch, Italian, Hungarian, etc. His concluding words are: "In the foregoing pages the reason will be found why I have not attached myself to either of the existing hypotheses, but could criticise them all with equal interest. It will readily be seen that I have honestly tried to be just to each, and I have never had the intention to place one author, or his hypothesis, above another. I have desired, by $111 y$ critical remarks, to stir up all to new labours, to obtain new proofs, while I have specially laid the emphasis on what we do not know.

"Darwinism proper, especially in the form presented to us by Haeckel (Weismann has found 110 real sympathy amongst anthropologists), appears to satisfy people less in the present day. The founders of the Descent or Selection hypothesis have thought they could tread down a path with seven-leagned boots which really still needs centuries of the most zealous investigation; to have acknowledged 
this is really a great step forward, which must produce fruitful results. The old, too much stereotyped statement of the case had a deadening influence, and was in many respects despotic; it was asserted that the path of evolution was known, the picture of Sais had been unveiled, and we were all required to admit it. (The picture of Sais is a mysterious one in an Fgyptian temple.)

"These considerations ought to convince everyone who is not biassed by these influences, that we really still know nothing certain about the great problem of Evolution, that we have never looked it full in the face. All must be built up afresin. We must aim therefore at a glorious, a restless struggling and striving for new methods and new investigations."

At the Anthropological Congress at Lindau, in 1899 , in speaking of Klaatsch's opinions as to a hypothetical ancestor of ape and man, Professor Johannes Ranke remarked: "Whilst a charming picture of the past and possibly of the future is being shown us, and whilst a fanciful design is being carried out in all directions, we are as a rule in quest of facts, not of theories. The facts, however, upon which Herr Klaatsch claims to base his ingenious theory, do not at present exist, and I must protest against his assuming that they have been really furnished by zoology and palæontology any more than by anatomy. . All else is still a matter of hypothesis, and if anyone attempts to use it in order to produce a finished picture, the result is a work merely of the imagination" (Quoted in Modern Biology, p. 463).

We have already seen what Professor Virchow said in 1893.

Professor J. Reinke, in Der gegenwärtige Stand der Abstammungslehre ('The present position of the theory of descent, 1902), says: "The only state- 
ment, consistent with her dignity, that science can make, is to say that she knows nothing about the origin of man."

And Professor W. Brancạ says : " Palæontology tells us nothing on the subject-it knows no ancestors of man.'

It must be clearly understood that none of these German scientific writers are advocates of the Biblical account of the origin of man. Some of them suppose that some day proof may be found of the descent of the human race from an animal stem : their point is that there are no proofs at present. We have seen that Professor Branca earnestly repudiates the idea that he writes as an advocate of Bible teaching.

\section{Man and the Animal.}

PROFESSOR VIRCHOW has reminded us that man has an animal organization, and that therefore we ought not to be surprised if some things in his body remind us of the animal.

Professor St. George Mivart says : If man, that is, if a rational animal were to be created at all, he must have been made more or less like some other animal," and then he shows that as he was not intended to creep on the earth, or to live in the water, or to fly in the air, he could not be made like a reptile, or a fish, or a bird, and that the most fittng animal for him to resemble would be found in the order Primates (Lessons from. Nature, p. 171).

It is clear that it was necessary for man to be created as a being who could walk, who could see and hear, who could eat and drink, and who could perform other functions of life, in many things similar to those which animals perform. His larger brain, his gift of speech, his more perfect hand, distinguish hin! from the animal world, and enable 
him to exercise that lordship over other creatures which God designed for him. But so far as he has needs similar to those of the animal world, is it astonishing that there should be some similarities in his body? He requires legs to walk, and is it to be wondered at that some of the muscles are like those of other walking animals? He must have eyes to see, and why should we expect them to be totally different from the eyes of other seeing creatures? The evolutionists are so obsessed with the idea that any similarity in structure, however small, between two organisms in nature must be a proof of descent from a common ancestry, that their arguments would almost seem to demand that the Creator, in introducing man into the world, ought to have formed a being utterly unlike any other existing being in every detail of his structure. Surely his bodily form, and his mental, moral, and spiritual nature sufficiently differentiate him from all other beings in the Universe.

No doubt if it could be proved that some organs in man's body are essentially harmful to him there would be something in this argument, though we know that many a inan's bodily weakness has often been a help to his spiritual progress. But the attacks made in former days upon the appendix, the colon, the thyroid gland, and other organs are now acknowledged to have had no foundation.

The article Anthropology, in the Encyclopedia Britannica, says :-

"It is in assigning to man his place in nature on psychological grounds that the greater difficulty arises. Huxley acknowledged an immeasurable and practically infinite divergence, ending in the present enormous psychological gulf between ape and man. It is difficult to account for this intellectual chasm as due to some minor structural difference. The 
opinion is deeply rooted in modern as in ancient thought that only a distinctive human element of the highest import can account for the severance between man and the highest animal below him. Differences in the mechanical organs, such as the perfection of the human hand as an instrument, or the adaptability of the human voice to the expression of human thought, are indeed of great value. But they have not of themselves such value, that to endow an ape with the hand and vocal organs of a man would be likely to raise it through any large part of the interval that now separates it from humanity. . . A As to the lower instincts tending directly to self-preservation, it is acknowledged on all hands that man has them in a less developed state than other animals."

There are other animals in some respects much nearer to man than the ape. The parrot can be taught to imitate the speech of man. The dog is specially the companion of man, and frequently shows wonderful affection for his master. As an old writer quaintly says: "A dog is the only thing on this earth that luvs you more than he luvs himself." And as for any approach to the intellectual powers of man, we find nothing in the higher animals at all to be compared to the intelligence of the ant.

In the opening words of his interesting book, Ants, Bees, and Wasps. Lord Avebury says: "The anthropoid apes no doubt approach nearer to man in bodily structure than do any other animals; but when we consider the habits of ants, their social organisation, their large communities, and elaborate habitations; their roadways, their possession of domestic animals, and even, in some cases, of slaves, it must be admitted that they have a fair claim to rank next to man in the scale of intelligence." 
It is probably impossible to define the difference between instinct and intelligence. If the bee had become extinct ages ago like the Cretaceous reptiles, and if fossil honeycombs had been discovered, might it not have been supposed that from their regular hexagonal form they could only have been the work of man? And if the beaver had disappeared, might not his dams have been set down as human handiwork?

A common illustration of the difference between the animal and man is that of the dog, who enjoys the fire, and has seen fuel put upon the fire again and again, but who never attempts to put any on himself !

Professor Otto, in his Naturalism and Religion remarks that the argument so often drawn from the alleged fact that there is less difference between a Fuegian and an ape than there is between a Fuegian and a European is obviously false, for, he says, "I can train a young ape or an elephant, can teach it to open wine bottles and perform tricks, but I can educate the child of the savage, can develop in him a mental life equal in firmness, depth, and energy, frequently more than equal to that of the average European, as the Mission to the Eskimos and to the Fiegians proves, and as Darwin frankly admitted" (p. 333).

And Dr. Archdall Reid says in his Evolution of Man: "There perhaps does not exist a potential Wrangler among the Bushmen, but judging from such children of savage parentage as have been reared in civilised communities, the average Bushman can be brought under fit training to closely resemble in his mental traits the average Englishman"' (p. 184).

Dr. Archdall Reid is a strong advocate of Evolntion. 


\section{The Antiquity of Man.}

APART from the question of the Origin of Man, there is that of the Antiquity of Man. How do the results of scientific research accord with the records of time given us in the Bible?

In the first place we must clearly understand that Archbishop Usher's chronology, which is to be found in the margin of the Authorised Version of the Bible, is of no authority whatever.

Next we must recognise that there are only two long periods of past time clearly stated in Scripture. We learn from 1 Kings vi. 1, that the building of Solomon's Temple was begun in the 480th year after the Exodus from Egypt. We also learn from Galatians iii. 17, that the Law was given 430 years after the promise was made to Abraham, so that we have 910 years from Abraham to Solomon. This can be shown to be not inconsistent with other passages, such as Acts xiii. 20 (when rightly translated), and periods mentioned in the book of Judges.

Also this chronology is not inconsistent with the three series of fourteen generations each, mentioned in Matt. i. 17. It will be noticed that these "generations" take us only back to Abraham.

\section{The Patriarchal Genealogies.}

ARCHAISHOP USHER's chronology was, of course, founded on the lists of the patriarchs given in Genesis v. and Genesis xi.

These genealogies have come down to us in different forms : first, in the Hebrew Bible, then in the Septuagint version, then in the Alexandrian version of the Septuagint, and then in the Samaritan Pentatelich. The numbers of the years of life of the Patriarchs differ widely in these various versions; and not only so, but there is very clear evidence that the alterations have been made intentionally. 
It is clearly impossible to form a chronology from the time of Adam to that of Abraham on such data.

Other facts show that we cannot take the figures as any guide to the period of time that elapsed between the Flood and the call of Abraham to Palestine. If we accept them according to the Hebrew Bible, Shem must have lived on far into the lifetime of Abraham, which, of course, is utterly inconsistent with the history. Then, if we turn to the genealogy of our Lord in Luke iii., we find that a second Patriarch of the name of Cainan is introduced, between Arphaxad and Sala, whom we do not find in Genesis. This raises the question whether many other names may have been omitted.

And if we examine other genealogies of the Old Testament we find without doubt that there were frequent omissions. The genealogy of our Lord in Matthew i. omits the names of four kings of Judah. In the genealogy of Ezra, given in Ezra vii. 1-5, several names are omitted, as will be seen from 1 Chron. vi. 3-14. An article on Primitive Chrono$\operatorname{logy}$, by Professor W. H. Green, of Princeton, in the Bibliotheca Sacra, April, 1890 (which is introduced in Dr. G. F. Wright's The Origin and Antiquity of Man), goes fully into this subject, and shows that this abbreviation of genealogies is characteristic of the Old Testament, though his illustration from the family of Moses is doubtful.

We may therefore conclude that the list of the post-diluvian patriarchs, at all events, is probably only a list of the most prominent men who were in the line of succession between Noah and Abraham.

And certainly the peopling of the world by the descendants of Noah, and the rise of the kingdoms of Babylon and Egypt, with their advanced civilisation, seems to require a much longer time than Usher's Chronology would allow. 
The antediluvian patriarchs stand on rather a different footing. In their case, not only is the age of cach given when the son was born who carried on the succession (of course, he need not have been the eldest son, though Dr. Driver assumes it in his Genesis, p. 75), but the length of years of his life after this son was born, and the two are totalled together to give his age at death. It is noticeable that this is not done in the case of the postdiluvian patriarchs (Gen. xi.). The differences in the figures, and the clear marks of intentional alteration of one list or the other, appear in the antediluvian as much as in the post-diluvian list.

That there are no omissions of names in the list of patriarchs before the Flood appears to be most probable, from the fact that in the Epistle of St. Jude, Enoch is referred to as " the seventh from Adam." And in 2 Peter ii. 5, Noah is referred to as the " eighth person," and although the R.V. alters this to "one of the eight," it is probable that the old reading is correct, and that the meaning is that Noah was the eighth person who was head of the family, neither Enoch nor Lamech having lived long enough to occupy that position.

\section{Longevity of the Patriarchs.}

Canon DrIVer, in his Genesis, says that the length of life attributed to the patriarchs is "physiologically incompatible with the structure of the human body" (p. 75).

Of course, it is practically impossible to challenge the accuracy of the original Scriptures in regard to figures which have come down to us in three or four different forms, so widely differing from one another. The diversities may be due to translation from one language into another, from mistakes in copying, or from a scribe misunderstanding some letters or 
figures, and there is just a possibility that the alterations may not have been intentional, though they appear so. But the differences may well cast some little doubt unon the original.

\section{What is Life?}

BuT does Science really say that such longevity as Genesis attributes to the patriarchs is an impossibility?

The fact is, that if there is one question that baffles science more than any other, it is: What is life?

Read the first chapter of Dr. Alfred Russel Wallace's recent book The World of Life, "What Life is," and it will be seen that even the definition of life is one of the most perplexing problems.

Sir George H. Darwin (son of Charles Darwin), in his presidential address at the meeting of the British Association in South Africa in 1905, said: "The mystery of life remains as impenetrable as ever, and in his evolutionary speculations the biologist does not attempt to explain life itself."

The chemist can put together the ingredients that form protoplasm, which is recognised as the physical basis of life, but when they have formed a substance it is precisely life which it lacks.

\section{What is Death?}

ANOTHER great difficulty of Science is: "What is death?" The late Professor Elie Metchnikoff, the successor of M. Pasteur, as head of the Pasteur Institute in Paris, in his book, The Nature of Man, discusses the question whether there is such a thing as natural death at all, that is, death not caused by some actual disease.

He says that scientific proof exists that our bodies contain immortal elements, eggs or spermatozoa ( $p$. 
268 ), and that natural death in man is probably a possibility rather than an actual occurrence (p. 277).

If natural death does exist, he says, "it must have appeared on the face of the earth long after the appearance of life." Weismann has suggested that " death arose as an adaptation for the advantage of the species, that is to say, in relation to the surrounding conditions of existence, and not as an absolute necessity inherent in the nature of the living substance."

Professor Metchnikoff was a strong Evolutionist, and had no belief whatever in the Bible as a Divine revelation, but, while he dismisses the genealogies of the earlier patriarchs as myths, he accepts the statements as to the length of life of Abraham, Isaac, Jacob, Job, Aaron, and Moses, and sees no difficulty in accepting them as credible history. He says : "The Bible testifies to the frequency of old age in ancient times, and to the complete preservation of the faculties in the aged"' (p. 281), and again, "One of the conditions that enabled the Jews of the earlier Biblical times to live longer than civilised people, was, beyond all doubt, the greater simplicity of their diet" (p. 292).

\section{Huxley on Early Man.}

In the prologue to a volume of his essays published in 1892, Huxley, accepting the doctrine of the descent of man from the animal, indulges in some speculations as to the process. He says :

"The results of the process of Evolution in the case of man, and in that of his more nearly allied contemporaries, have been marvellously different. Yet it is easy to see that small primitive differences of a certain order must in the long run bring about a wide divergence of the human stock from the others. It is a reasonable supposition that in the 
carliest human organisms an improved brain, a voice more capable of modulation and articulation, limbs which lent themselves better to gesture, a more perfect hand capable among other things of imitating form in plastic and other material, were combined with the curiosity, the mimetic tendency, the strong family affection of the next lower group; and that they were accompanied by exceptional length of life and a prolonged minority. The last two peculiarities are obviously calculated to strengthen the family organisation, and to give great weight to its educative influences" (p. 47).

If Huxley could assume the probability of exceptional length of life in the earliest members of the human race, just emerging, according to the doctrine of evolution, from animal ancestry, is it unreasonable to believe that man, as we read of him in the Bible, fresh from the Creator's hand, and with no inherited discases in his blood, and living a simple pastoral life, may have attained an age far beyond any experience of historical times?

\section{The Glacial, or Pleistocene Period.}

IN the preface to Professor Keith's book, which we have so often quoted, he mentions four distinguished modern geologists as the successors of Sir Charles Lyell, and among them Dr. G. Frederick Wright, of Oberlin, Ohio. In his chapter on North America (chap. xvi.) he mentions Dr. Wright as one who has specially studied "the physical condition of North America during the Pleistocene period." He refers to Dr. Wright's book, The Origin and Antiquity of Man, and speaks of him as one "who has given a lifetime to the study of glacial deposits " (Antiquity of Man, pp. 273, 281).

We may therefore, with some confidence, go to Dr. Wright's book for his opinion as to the length 
of the Pleistocene period and the date from which man is proved, from geological evidence, to have existed on the earth. He says

"Coming down to the consideration of the length of Pleistocene, or Post-Tertiary, time, which is the only geological age in which we find satisfactory evidence of the existence of man, there is ample evidence to show that relatively it was not more than one-fifticth that of Tertiary time. With that estimate, the total length of the Glacial epoch would be only 30,000 years if we give $24,000,000$ years as the age of the oldest sedimentary strata, and only 90,000 years if we allow for an increase of threefold. At the same time, many lines of direct evidence from the recession of waterfalls, the accumulation of sediment in lake bottoms, the short continuance of glacial lakes, like that which covered the Red River Valley of the North during the glacial recession, and the sinall enlargement of post-glacial river channels, render incredible the current estimates of the length of post-glacial time. Post-glacial time is to be reckoned by thousands of years, rather than by hundreds of thousands, or even tens of thousands.

"Inattention to the actual facts, and lack of true scientific inagination have conspired to exaggerate beyond all reason the length both of geological time in general, and of post-glacial time in particular during which man has been an inhabitant of the carth" "The Origin and Antiquity of Man, pp. 480481).

He goes on to say that " recent observations have demonstrated that geologic forces are immensely more active than they were formerly supposed to be, and that there have been periods of rapid advancement when everything moved on by leaps and bounds," and he refers to the rate at which rivers like the Mississippi, the Ohio, and the Colorado, are 
at present scouring out their channels (p. 481). He then reviews the geological evidence in regard to the Glacial period, and its connection with man, and he comes to the conclusion that "while the antiquity of man cannot be less than ten thousand, it need not be more than fifteen thousand years. Eight thousand years of prehistoric time is ample to account for all known facts relating to his development" (p. 496).

If we accept this judgment, and if we consider. the names of the post-diluvian patriarchs in Gen. xi. to be only those of the most prominent men in the line of succession between Noah and Abraham, all difficulty as to reconciling the time demanded by Science for the existence of man with the Mosaic account will be taken away.

We may notice that Sir J. W. Dawson, the cminent geologist, in The Meeting Place of Geology and History (1895), said: "The certainly known remains of man, whether attributed as by some to the latest inter-glacial period, or to the post-glacial-a mere question of terms, and not of facts-cannot be older, according to the best geological estimates, than from seven thousand to ten thousand years" (p. 21).

\section{Glacial Epochs.}

DR. WRIGHT says: "There have been three, and perhaps four, glacial advances in the United States with inter-glacial periods between " (p. 205), and he finds evidence of man's existence in what is called the "Terrace epoch," when, at the decline of the glacial period, gravei terraces were laid down by the glacial floods along the borders of the Connecticut, the Hudson, the Delaware, the Susquehanna, the Ohio, the Mississippi, the Missouri, and other rivers ( $p .218$ ). He says that the origin of these 
terraces is capable of being proved to a very high degree of certainty (p. 219).

From the article Glacial Period in the Encyclopadia Britannica we learn that Professor James Geikie and other geologists recognise several different glacial epochs in Europe, though there is much difference of opinion on the subject.

We have seen that all the human remains in Europe of which there is any clear proof belong to the Pleistocene period, when glacial conditions obtained in all the Northern regions of the world. This period seems to be one of special difficulty to geologists, for in the chart given in his article Geology, in the Encyclopcedia Britannica, Sir A. Geikie says, "In North America, as in Europe, it is hardly possible to assign a definite chronological place to each of the various deposits of this period (the Pleistocene), terrestrial and marine" (p. 670).

And then from the article Pleistocene in the same work we learn that there is a certain indefiniteness as to the exact base time to be adopted for the Pleistocene formations, and that "it is clear that in parts of Northern Europe, Siberia, and North America, the conditions characteristic of a glacial period are still existent "; that even in Scotland and Norway the last traces of glacial action are "remarkably fresh," and that " the last remnants of great glacial centres still linger in the Alps and other lofty southern mountains." The article continues: "It is a matter of extreme difficulty-one may say impossibility - to reduce the Pleistocene formations to any generally applicable chronological order."

Clearly the age of any remains found in these deposits must depend on whether those deposits belonged to the earlier or later portion of the period, and the difference would be enormous. 
It is rather startling to reat one sentence in Dr. Wright's chapter on The Significance of the Glacial Epocin: "Large areas in Europe and North America, which are now principal centres of cirilization, were buried under glacial ice thousands of feet thick, while the civilization of Babylonia was in its heyday" (p. 195). "This rather revolutionises some of the ideas we have formed from reading other literature about prehistoric tines. But, speaking generally, the glacial ice only reached the northern parts of Europe and America; it covered Scandinavia, and the northern portions of Great Britain, Germany, and Russia, but very little of France, though it spread over Switzerland and Northern Italy: in North America it probably came as far south as the River Ohio. But Dr. Wright says: "Paradoxical as it may seem, it was soon after the cilmination of the glacial epoch that the conditions-in Central Asia were most favourable for the support of a dense population both of aninials and man; for it was at. that time that the oases on every side were expanded to their greatest extent, and that the climate was most salubrious. The inore ice there was to melt upon the mountain heights, the larger the streams which sent their life-giving waters to the fertile belt of soil spreading out in every direction from the base of the mountains. . The fertility given by the Nile to Egypt is even now insignificant compared with that which is poured upon Central Asia by the innumerable melting glaciers nourished at the more than Alpine heights which look down upon the region from every side" (p. 367).

Again: "But at the same time that conditions were so favourable for the increase of population in this region, they were absolutely prohibitive of the existence of man in what are now the most fertile portions of Europe... Russia, Scandi- 
navia, Northern Germany, the British Isles, and Switzerland"' (p. 368).

"It is an interesting fact," says Dr. Wright, "that nearly all the waterfalls of the world are postglacial, and that with few striking exceptions there are no waterfalls in the unglaciated regions" (p. 175).

\section{Niagara.}

THE gorge below the Falls of Niagara has been taken as a convenient glacial chronometer. Sir Charles Lyell visited Niagara in 1842, and Dr. Wright says that he made a random guess that the recession of the Horseshoe Falls could not be more than one foot a year, and probably not more than one foot in three years, and this would make the age of the gorge from 35,000 to 100,000 years. But several subsequent surveys have shown that the average rate of recession has been a little over five feet a year, so that at the same rate the Niagara River would have eroded the whole gorge in 7,000 years. At the Falls of St. Anthony, at Minneapolis, Minnesota, "uniger the prolonged and careful study of Professor N. H. Winchell, similar results have been attained" (p. 179).

Dr. Wright adds: "The glib manner in which many, not to say most, popular writers, as well as many observers of limited range, speak of the glacial epoch as far distant in geological time, is due to ignorance of facts which would seem to be so clear that he who runs might read them " (p. 195).

The problem of the remains of man in conjunction with those of the mammoth is satisfactorily solved when we read Dr. Wright's explanation: "The evidence is indubitable that the mammoth long survived the close of the Glacial epoch, since his remains are frequently found in post-glacial peat bogs and quag- 
mires. He was not killed by cold but by warnth" (p. 361).

\section{The Swiss Glaciers.}

A Boor has recently appeared by Mr. J. Y. Buchanan, F.R.S., containing some information as to the Swiss glaciers, which gives an entirely new view as to the probable distance of time to which we have to look back for the Glacial Period. A review in The Times Literary Supplement for April 12th, 1917, gives the following extract:-

"The old men, like Hugi, Agassiz, Forbes, and even 'Tyndall, knew nothing of decaying glaciers. Oscillations, 110 doubt, there were, but all these glaciers, in the main, held their own. . . (But if) the old men never saw a decaying glacier. none of the present generation of observers has ever seen a robust one. M. Vallot, who has charge of the observatories of Mont Blanc, pointed out a few years ago that the sinking of the glaciers in the Chamonix district amounted then to fully oneeighth of the total amount of sinking since the last ice age. But the recent slirinkage of the glaciers has taken place in fifty years; therefore at the same rate the whole shrinkage from the extension of the glaciers in the ice age to their present state may have taken place in 400 years."

The reviewer of Comptes Rendus says: "This important conclusion gives us a weird feeling of intimacy with the ice age, all the more because we are accustomed to hear geologists talk of periods of time in big figures. Mr. Buchanan has developed a theory of the formation of sea and glacier ice which gives the key to many puzzles."

"The enormous diminution of the Rhine glacier in half a century" is also spoken of, and it would appear that the facts brought forward in this book tend strongly to confirm what Dr. Wright tells us 
as to the Glacial Epoch not being so renote as has been generally supposed.

\section{The Palæolithic Period.}

THE immense difference between Dr. Keith's cstimates of geological time since man appeared, and the estimate of Dr. Wright, lies chiefly in the Palæolithic period. Dr. Keith places the end of the Neolithic period about 2,000 B.C.- - that is, the time of Abraham. He vaguely supposes that the beginning of the period may have been 6,000 or 8,000 years earlier, but he admits much uncertainty. "The Palæolithic cultures," he says, "lie within what is regarded as the Ice age, but which it is better to speak of as the Pleistocene epoch" (Antiquity of Man, p. 62). From what we have seen in the earlier part of this book there is no certainty at all about any remains of man in the Pliocene. It is therefore almost entirely a question of the length of the periods included in the Pleistocene epoch.

Sir A. Geikie, in his article Geology, in the Encyclopcedia Britannica, certainly secms, in his table of the Stratified Formations of the Earth's Crust, to treat the Palæolithic period as following the Pleistocene, but this is probably explained by the uncertainty of which he speaks as to the various deposits of the Pleistocene. The end of the Ice age no doubt varied in the different northern portions of Europe and America.

Dr. Duckworth gives a table of the subdivisions of Palæolithic or Pleistocene time, according to different writers - the Chellean, Achenlean, Mousterian, Solutrean, Magdalenian, etc., arranged according to the implements, etc., found, and it shows great difference of opinion (Prehistoric Man, p. 119). Mr. J. A. How, in the article Pleistocene, in the Encyclopadia Britannica, says that "the terms 
Magdalenian, etc., are really archeological, basted upon the character of the implements found in the deposits, and like the similar terms 'eolithic' and 'palseolithic' they are of little value in geological chronology, unless they are supported by palzentological evidence."

Dr. Diakworth says that "almost the only point of accord betrecen the rival sthools of thought consists in the recognition by each side that the Magdalcnian culture is post-glacial" (p. 121). IIe adds: "In these controversies, the tendency is very marked to allow therry to run too far ahead of fact" (p. 124).

\section{The Eoliths.}

A creatr deal of contropersy has been called forth by the discoveries of primitive flaked flints found in many places, often in deposits assumed to belong to the Tertiary period, and which are assumed by many authorities to be implements fashioned by human hands.

These are generally known as eoliths-the nane meaning "stones of the dawn "- - that is, of course, the dawn of life on the earth.

In regard to all such relics there are naturally always two questions:-

1. Are the deposits in which they were found unquestionably of Tertiary age?

2. Do the objects found show unquestionable signs of human workmanship?

Professor Keith, in The Antiquity of Man, accents as authentic several such relics found or vouched for by Sir Josepla Prestwich, Professor A. Rutot, Mr. Reid Moir, and others. A great many of these rudely worked flints are in the passession of $\mathrm{Mr}$. Benjamin Harrison, at Igtham, in Kent.

But Dr. Kcith acknowledges that the "humanity" 
of several of these objects has been called in question (pp. 225, 257, 511).

Some such flints have been found in Egypt, and some by Dr. Noetling, in Burmah. M. Rutot's finds were at St. Prest, near Paris.

Dr. Duckworth, in discussing the eoliths, says: "The question is far from the point of settlement, and it may well continue to induce research and discussion for years to come' (Prehistoric Man, p. 110).

Mr. Marett says: "The subject (of eoliths) is one that invariably sets pre-historians at each other's throats" (Anthropology, p. 41).

Dr. G. F. Wright discusses some of the discoveries of worked fints in France and England, but most of those he refers to are palæolithic, and, as many remains of man's body belong to this period, the implements afford no further evidence of his existence (The Origin and Antiquity of Man, p. 290 et seq.).

After mentioning Professor Rutot's discoveries, and some experiments by $M$. Boule, he says: "It would now seem that the evidence for the artificial character of the chippings on eoliths is insufficient to establish their genuineness" (p. 338).

As to some other discoveries by the Abbe Brevil, he quotes Professor Sollas: "These (eoliths) were found by Abbé Brenil in Lower Eocene sands at Clermont (Oise). M. Breuil shows in the most convincing manner that they all owe their formation to one and the same process, i.e., to movements of the strata while settling under pressure of the soil" (p. 340).

Professor Osborn, in Men of the Old Stone Age, is also very suspicious of the "humanity" of the eoliths.

Some work on stones may probably be due to animals. Dr. A. T. Pierson relates that some bones, cut and polished, having been found in very ancient 
deposits, Sir Charles I,yell put among the beavers in the Zoological Gardens some similar bones, and, after some time, recovered them, "cut and polished by the beavers, so nearly like the others as to leave no doubt that in both cases the same agency had been employed" (Many Infallible Proofs, p. 139).

In this connection we may remark what Professor Virchow said at the Congress of Moscow on the subject of flint implements: "At the congress at Lisbon we were taken to the plain of Otla, where we found flint chips, but we were far from being convinced that these flint chips were distinguished in any respect from the débris which is found in the ground everywhere, and which results from the disintegration of a siliceous soil. Nobody has ever found in virgin Tertiary strata any piece of flint that has been recognised by the learned world as an unquestionable relic of the existence of man. We have likewise reached the same result in our search for human skulls and bones.... We find a great void which we try to fill with fantastic imaginings, but which furnishes us with no real specimens" (popular Science Monthly, January, 1893).

\section{Flints Chipped by Nature.}

THE article Archoology, in the Encyclopedia Britannica, by Dr. C. Hercules Read, President of the Society of Antiquaries of London, sums up the evidence on this subject generally. Dr. Read says : "Although there is no valid reason against the existence of Tertiary man, it must be confessed that the evidence in favour of the belief is of a very inconclusive and inconvincing kind . . . It is an obvious fact that natural forces, such as glacial action, earthquakes, landslips, and the like must crush and chin flints, and break up animal remains, grinding and scratching them in masses of gravel 
and sand .. Even the one feature that is commonly held to determine human agency, the bulb of percussion, cannot be considered satisfactory without collateral evidence of some kind. Flint breaks with what is called a conchoidal fracture, as do many other substances, such as glass. . . The bulb of percussion has come to be regarded as the hall-mark of human manufacture; but recent investigations have shown that the intervention of man is not necessary, and that natural forces frequently produce a similar result.

"There can be no doubt that much time and energy have been wasted, and a number, of intelligent workers have been fruitlessly occupied in following up archæological will-o'-the-wisps" (p. 344).

Again: "The controversy as to the human character (of the eoliths) has been very keen, some alleging that the fractured edges and even the definite and fairly constant types are entirely produced by natural forces. Sir Joseph Prestwich, in England, and Alfred Rutot in Belgium, the latter arguing from his own discoveries in that country, have strongly supported the artificial character of the relics. . . The critics of eoliths have brought forward some facts that at first sight would seem to be of a very damaging nature. It was observed that in the process of cement manufacture the flints that had passed through a rotary machine, in which they were violently struck by its teeth or knocked against each other, possessed just those features that were claimed as indisputable proof of man's handiwork, and that even the forms were the same. These statements have, of course, been met by counter statements equally forcible" (p. 345).

As regards any light on the subject from the American Continent, there is an article by Dr. Clark 
Wissler, of the American Museum of Natural History, on The Present Status of the Antiquity of Man in Nortl. Amcrica, in the Scientific Monthly for March, 1916. Dr. Wissler says: "European investigators have achicved their greatest trimmphs from discoveries of the débris of human cultures, but similar deposits have not come to light in America. The claims of Abbott, Volk, and others have been based almost entirely upon random finds of stone or bone worked by man.... . The American literature of some twenty years ago is curiously characterised by affidavits and sworn statements as to the exact place, position, identity, etc., of the single objects found. 'This itself effectively demonstrates the insufficiency of the data. . . The necessity of depending entirely upon the mere assertions of an individual would leave us no recourse but extreme scepticism. . . . These random American finds too strongly suggest errors in observation and natural accidents of deposition to afford a basis for any kind of scientific or mere speculative structure" (p. 235).

Perhaps the latest paper on eoliths is one by $\mathrm{Mr}$. Reid Moir, in Science Progress for Jannary, 1917, which deals with flaked fints found in Kent, and at Ipsprich, Lowestoft, etc.

\section{Forgeries.}

$O F$ course, there have been some forgeries of flint instruments at various times. The article Archoology in the Encyclopedia Britannica says: "Apart from Edward Simpson, who was notorious as 'Flint Jack' in the middle of the 19th century, many others, both in England and on the Continent of Europe, have devoted themselves to this peculiar industry. Boucher de Perthes tried to conquer the scepticism of some of his friends who 
rloubted the human origin of the Abbeville flints by unwisely offering his workmen a reward for the discovery of human bones in the same beds. The Moulin Quignon jaw was accordingly produced, and becamc the subject of much controversy ; but the evidence finally showed that it had originally come from elsewhere. The cave drawings also have found their imitators in modern times. . . In Snitzerland also a brisk trade was carried on sone years ago in false antiquities said to come from the Irake dwellings. . . A Anerica has provided similas feod for discussion in the well-known Senape stone and the Calaveras skull" (p. 347).

\section{Views of Theological Writers.}

Quni: a number of Christian writers have accepted to a great extent the evolutionary doctrine of the origin of mankind, and have endeavoured to show that it is not inconsistent with the first two chapters of Genesis. Many of these are, of course, writers who more or less accept the teachings of the Higher Criticism. These views are found in several cases in broks written in defence of the Bible: in other cases in books or lesson helps for teachers of the young.

\section{Evolution and Genesis.}

"Thu grand and poetical imagery of the opening chapters of Genesis," is a phrase used in The II ystery of Life, by Bishop J. E. Mercer (late Bishop of Tasmania), and he accepts evolution in the widest sense, and expressly includes the theory of spontaneous generation, which neither Darwin nor Herbert Spencer accepted.

Canon J. M. Wilson, of Worcester, in Evolution and the Holy Scriptures, says that "the law of Evolution does in all probability apply, more or less completely to the origin of all species," but that Dar- 
win's explanation does not account for all the facts, and does not exclude the possibility of Design acting through evolutionary methods.

The Book of Genesis, by Dr. Marcus Dods, is in many ways excellent in its treatment of the narratives of the lives of the patriarchs generally, and draws most helpful lessons from them, but its view of the earlier chapters is "that in these chapters we have the ideas regarding the origin of the world and of man which were naturally attainable in the country where they were first composed, but with those important modifications which a monotheistic belief necessarily suggested" (p, 8).

We are told that they teach that there has been a creation; that things have been called into being by a presiding intelligence and an originating will, and that man was the chief work of God. According to Dr. Dods, what the Kriter of Genesis had learned of God's unity and creative power in connection with man by the inspiration of the Holy Spirit " he imparts to his contemporaries through the vehicle of an account of creation they could all understand" (p. 6).

Canon Driver, in The Book of Genesis, in the Westminster Commentaries, says: "The general trend of modern science is to regard man as laving developed gradually out of humbler anthropoid ancestors: and the possibility of this theory being true must at least be reckoned with by the theologian'" (p. 54).

Dr. H. A. Redpath, in Modern Criticism and Genesis, appears to approve of Dr. Driver's point of view, and he suggests that the union just before the Flood between the sons of God and the daughters of meri may refer to unions between the race of inan and remaining individuals of the anthropoid race. 
But on the other hand he strongly commends Professor James Orr's God's Image in Man, which argues at some length against the theory of human evolution.

Dr. Paterson Sinyth, in The Bible for the YoungGenesis, says: "This Creation story is the foundation of all science, as well as of all religion," but at the same time he says: "Men saw that the Creation story was at least not incompatible with evolution " (p. 10).

The Rev. C: L. Drawbridge, Hon. Sec. of the Christian Evidence Society, has a chapter on Evolution and Creation, in his book, Common Objections to Christianity, in which he says that Evolution is nothing more than a theory, and at the same time he shows by several illustrations that there is no necessary contradiction between evolutionary method and creative agency. "Nature is the effect of which God is the Cause." But he does not deal with the actual statements in Genesis as to the creation of the world and man, and though mentioning "our first parents," he appears to leave the origin of man very much an open question.

Some Notes on the International Lessons for January, 1913, appeared in the Sunday School Chronicle, written by Rev. J. D. Jones, of Bournemouth, and in these he dealt with the first chapters of Genesis. He said that the two narratives of the creation of man could not be interpreted literally, and he held that "the broad truth of evolution is practically established." At the same time the actual creation of man in the image of God appears to be accepted in the Notes.

In Dr. F. N. Peloubet's Select Notes on the International Lessons for 1913, we read in the note on 
Gen. ii. T: "There is nothing in this account contrary to the evolutionary theory that the body of man was evolved by development from lower animals. The very word formed, as distinct from create, permits this belief. For every animal's body is made of the dust. There is nothing unworthy in the idea, but Professor Dwight, late of the Harvard Medical School, recently stated in public that it is not proved that inan came from the lower animals."

Rev. Professor G. Henslow's Present Day Rationalism Critically Examined is an argmment agalust Rationalism and Naterialism, but when we read: "The conception that all men became tainted through being descended from Adam and Eve is, of course, a pure fiction" (p. 325), we clearly see the drift of the book. Professor Henslow accepts the theory of Evolution, including man, but he rejects Watural Selection, and contends for some inner vital force which he calls Directivity.

The Dean of Wesminster (Bishop Herbert Ryle) in his Early Narratives of Genesis, says : "So far as his (man's) physical origin and his material structure are concerned, the advances of modern physiological research are more likely to furnish a bey to the great mystery than are the pages of Crenesis. But when we pass from the consideration of inan's physical structure to the consineration of him as one endowed with spiritual powers, moral duties, and intellectual gifts, we are lifted at once into an: atmosphere where we find that every item of the description is marvellously and perfectly in harnony with the bighest religious conception of mau revealed to us in the teaching of the Incarnation. We see Him made in the image and likeness of God; a living soul derived from the Divine Spirit; gifted with powers of intellect, with freedom of will, with the witness of conscience " (p. 11). 


\section{"The Ascent through Christ."}

A BOOK which has undoubtedly exercised a very wide influence, especially amongst Nonconformists, is The Ascent Through Christ, by Dr. E. Griffith Jones, published in 1899 . Some brief extracts will best explain its teaching.

"Just as no possible bridge can be thrown across the chasm that separates the material from the psychical, so no possible bridge seems capable of being thrown across that subtle but no less real chasm which separates the self-conscious from the merely conscious creature" (That is man, and the animal).

"With this essential qualification .. . We shall find no difficulty in fully accepting the evolutionary. theory of man's physical origin, and to allow, to a large extent at least, his mental as well as physical kinship with the lower orders" (p. 44).

"We take up the position that it has been substantially proved, so far at least as the physical nature of man is concerned, that 'descent with inodification' from some earlier and extinct species of creature accounts for the structure he possesses and the functions he fulfils in common with the lower aninals" (p. 47).

"At some far-off period-so far off indeed that no) record of it will ever be found-the moment came when mental changes became of more importance than physical changes to the brute ancestor of man. Silently and unnoticed, the great day of man dawned ; without observation he entered in to his distinctive heritage" (p. 50).

"How he first became conscious of the existence of a Higher Being or Beings, is a question of great interest and of great difficulty" (p. 65).

It is next explained that Evolution does not do away with God as Creator. 
"This does not in any way touch the question of creation as a fact, but only the method of creation" (p. 68).

Several chapters are devoted to the bearing of the doctrine of Evolution upon the Fall of Man. On page 188 we read: "In what form precisely the first solicitation to do wrong appeared before the dawning moral sense of man we shall never know, nor is it needful that we should. The essentials of the situation are that he should have become possessed of sufficient moral insight to recognise a higher and a lower alternative, and of a sufficiently developed will to be in a position to choose either."

On page 189, and following pages, there seems to be an attempt to read evolutionary teaching into the language of St. Paul. "Henry Ward Beecher says that 'it is out of the power of any man to give connected and perfect interpretation of these two immortal chapters, the seventh and eighth of Romans, except upon the substantial theory of Evolution'" (p. 189).

Further on we read: "So far the interpretation put upon Paul's language by Fiske and Beecher is right-that once the principle of evil had entered into human nature, it found in the unregulated bodily passions, which were the true heritage of the animal nature, ready and effective instruments for the working out of its will. . . A the same time the animal side of human nature is in itself as nonethical as it is in the brutes from which man inherits his physical organisation; the will alone is ethical. and therefore the will alone can be the true seat of sinful act and bias" (p. 192).

It has been needful to make these quotations from the book of Dr. Griffith Jones, as it is so essential that we should realise what must necessarily be the influence of the doctrine of buman evolution upon 
the ideas of men in the present day upon the nature of Sin. And a final quotation will show us how intimately the whole question is bound up with that of the inspiration of God's Word. On page 108 we read in regard to the first eleven chapters of Genesis : "The whole of this early Jehovistic literature is really an editorial handling of legends derived probably from many sources, with a view of showing the progressive ravages of $\sin$ in the subsequent history of the race."

A small book that has recently appeared, Seven Doubts of a Biologist, by the Rev. Stewart McDowall, Chaplain at Winchester College, contains a great deal that is fresh and original. The first chapter says :-

"This book is designed to sketch in outline how the doctrine of Evolution itself can lead to faith, and in it everything is going to be looked at through the spectacles of a thorough-paced evolutionary philosophy"' (p. 8).

Under the heads of God, Sin, Atonement, the Goodness of God, Prayer, Heaven, the Holy Trinity, it speaks of the doubts men have raised on these subjects, and argues that the theory of Evolution does not contradict the teaching of Scripture in regard to them.

But surely few evolutionists would accept this definition of the theory: "Evolution is nothing more nor less than adaptation of one kind or another. It represents the creature's response to the stimuli of its environment, or, to be a little more exact, the response of a whole line of creatures, stretching back into a dim perspective of ancestors, and forward into a dimmer perspective of descendants yet to come" (p. 9).

The author says: "Nothing at all could develop except in response to the environment. There 
would be no fins if there wasn't water: no legs if there wasn't land: no wings or limbs if there wasn't air, and so on."

And further: "Our root principle, then, is that evolution can only take place in response to the covironment, and that the response must be a suitable one" (p. 11).

This is certainly a remarkable style of reasoning. It is one thing to say that changes could not take place without a suitable enviromment, but surely quite another thing to assert that all the changes needed to evolve the higher animals and man out of one or more specks of protoplasm could have been brought about by change of enviromment alone. There are some suggestive thoughts in the book which make it worth reading, but needless to say, the ideas should be tested by Scripture.

\section{"The Truth of Christianity."}

Or' all the books on Christian Evidences, Iicut.Colonel Turton's The Truth of Christianity is perhaps the most widely known, as it has received such a large number of favourable comments from the press. He accepts the theory of Organic Evolution entirely, or perhaps we should rather say that his argument is that we need not consider that its acceptance, including the evolution of man-physical, mental, and spiritual -involves any contradiction to the truth of Scripture. But then his contention is, that the method of this evolution most probably has been by what he terms Supernatural Selection (p. 27 ) : that is to say, "due to the continuous action of the Creator," directing every step in the process (p. 26).

Of course, if we conld take this view of Evolution, it would make it something totally different from the Darwinian theory. We know that God feeds the 
ravens, that He clothes the lilies with beauty, that He numbers the hairs of our head, that not even a single sparrow is forgotten by $\mathrm{Him}$ : we cannot say that any changes in the physical constitution of animal or man would be too insignificant for Him to care for, nor could we say that anything would be impossible to Crod. But we know that the changes which have come about in various breeds of animals through artificial selection have been wrought by man, acting in accordance with well understood natural laws, and the main contcntion of evolutionists is, that similar changes bave operated in Nature in the course of ages, producing results immensely larger, as some would say by chance, but as others would say, following some natural law that has not yet been fully discovered.

(We shall speak of Artificial Selection later on.)

Colonel Turton, while bringing forward this idea of an evolution by "supernatural selection," also admits the possibility of another view-that "everything in nature may have been brought about in accordance with fixed laws," foreseen and designed by the Creator, by the process of evolution, and he says: "It seems to many to be a far nobler conception of the Creator that He should obtain all the results $\mathrm{He}$ desired by one grand system of evolution, rather than by creating each species separately"' (p. 28).

Either of these suggestions of Colonel Turtou would surely, as regards the descent of man from an ape-like ancestor, involve all the difficulties which have been already considered on pp. 112, 113. Anything is possible, no doubt, if we suppose supernatural intervention at every point, but why should we, in defending "The Truth of Christianity" from rationalistic or agnostic attacks, ask the doubters to believe in an infinite number of miracu- 
lous interferences with the known laws of nature of which Scripture does not give the slightest hint?

As regards Colonel Turton's second suggestion, it is difficult to see how it differs from some of the evolutionary theories which have been advanced as a substitute for Natural Selection, and which suppose that there is some inner directive force in organisms of all kinds in Nature.

Although we cannot agree with Colonel Turton on this subject, and on some other points in his book, it is one that contains much valuable material for the student.

\section{"The Conflict of Truth."}

The Conflict of Truth, by Mr. F. Hugh Capron, published in 1902, is a book that has certainly exercised a great influence upon thinking men, judging by the way in which it has been referred to by some well-known writers. The first part of the book is a strong criticism of Herbert Spencer's philosophy. Mr. Capron endorses the view of Professor St. George Mivart and Dr. Russel Wallace, that " man's material and physical parts are the product of the law of Evolution; whilst his spiritual part, in its inception, was the product of a process described as Creation" (p. 284), and his theory is that when man became fitted "by virtue of his physical and intellectual proficiency to receive the attribute of Spirituality," Grod then " conferred this new and transcendent gift upon a single member of the race, who may be presumed to have been the first member who had attained to the required standard of physical and mental perfection" (p. 285). Fe then admits that it is in the highest degree probable that there was no female being so advanced as to be "fitted to receive the same mysterious gift," and he concludes that a help-meet 
for Adam was provided by a miraculous intervention (p. 288).

In a very long argument, occupying many pages of his book, Mr. Capron shows that if the evolutionist could produce specimens of all the supposed links between the ancestral ape and modern man, it would be impossible for him to say where, exactly, the animal became man. From this we gather that it does not follow that his theory teaches us that Adam began life as an animal, for the change to man may have come some generations earlier.

Mr. Capron suggests that the Canaanites, who were destroyed when the Israelites conquered Palestine, were not descendants of Adam, but were descended from members of the anthropoid race who had escaped the Flood, and he also supposes that the "daughters of men," mentioned in Gen. vi. 2, may have been of the same race, though he admits that this is only a speculation upon an obscrire passage (p. 294).

Then he propounds a truly extraordinary theory: that it does not follow that every being possessed of spiritual life must be Adam's physical descendant, and, quoting our Lord's words to Nicodemus in John iii. 6, and some other passages of Scripture, he comes to the conclusion (though the idea is expressed vaguely) that some members of what we may call the "earlier race" may have received, through Adam or his descendants, "the faculty for acquiring spiritual life."

\section{"Facts and Fallacies."}

DR. W. WOODS SMYTH, who is a very strong advocate of the literal interpretation of Scripture, and who some years ago wrote a series of articles in The Life of Faith on the Bible, takes a somewhat similar view in his Facts and Fallacies regarding the Bible. 
He contends that the form in which the verbs are given in the first chapter of Genesis imply creation by the method of evolution. He holds that before Adam there were "lower races of men, going back in links to generalised forms related to anthropoid or man-like apes" (p. 69). Then, he says: "The Lord selected a man-the fittest of all men to receive the revelation of Himself . . that the perfected man might be preserved and the progressive evolution of the race in a new and higher form might continue" (p. 91). A few pages later he accepts the account in Genesis of the creation of the woman (p. 99).

As this book was specially recommended in a letter to the Record by the Bishop of Durham, it has no doubt been widely read. It treats the accoint of man's creation in the first chapter of Genesis as referring to the earlier race of men, "the outcome of the great majestic and Divine ordinance of Evolution" (p. 69), while the second chapter only refers to Adam. Then it supposes Adam to have been one of those early men who, "having received, in addition to his perfected humanity, the Breath, that is, the Spirit of God," became the son of God : and was placed in Paradise. "We can thus understand the Scripture," continues Dr. Smyth, "which writes that the 'sons of God' (i.e., the descendants of Adam) 'saw the daughters of men that they were fair, and they took them wives,' and makes clear to us also from whence Cain obtained his wife" (p. 75).

Colonel Turton also holds that there were preAdamite men, and that Genesis i. 26, 27, refers only to the creation of the human species, and Genesis ii. to the creation of Adam, and he thinks that Cain's wife was of the earlier race.

One feature of Dr. Woods Smyth's book is, that while Mr. Capron devotes a great part of his work 
to a refutation of Herbert Spencer's philosophy, Dr. Smyth justifies his arguments by very numerous quotations from Spencer.

\section{Pre-Adamite Man.}

SOrre other theologians have imagined a preAdamite race of men who existed and perished in some far-off geologic age, and the suggestion has generally been made, apparently, as an easy way of accounting for traces of prehistoric man, some of whom may have survived the Deluge.

It is a pity that any responsible writer should take seriously the old infidel question, Where did Cain get his wife? Common sense tells us that Cain must have married one of his sisters, for the simple reason that they were the only women in the world, and as to Cain's fear that anyone finding him might slay him, doubtless, by the time his crime was committed, Adam's family was a numerous one. The statement in Genesis v. 4, that Adam "begat sons and dalighters," does not by any means imply that this was only after the birth of Seth.

All these attempts to reconcile with Scripture the theory of the evolution of man from an animal stock sirely create more problems than those they attempt to solve. If men who were the product of evolution existed before Adam, there could not have been one race: there must have been many races, for it would have been impossible to account for the disappearance of all descendants of intermediate forms between animal and man, or for those having left 110 descendants.

And then to suppose that a race of men not connected with Adam co-existed in the world with Adam's family, is surely contrary to the general tenor of Scripture. The practical difficulty must be obvious: if there was intermarriage between the 
two races, as there must have been, were the offspring of these marriages men with immortal souls, or what were they? The great majority of commentators, and certainly those of the highest standing, explain the passage in Ge1l. vi. as to the sons of God and the daughters of men to refer to unions between the family of Seth, who had kept the true faith, and the descendants of Cain, who had departed from it. Then, to imagine any human beings having escaped the Flood, seems to be contrary to the whole teaching of the chapters that relate the history of Noah.

\section{Failure of Reconciling Theories.}

BUT the all-important question is, can we by any possibility make the record of man's creation in Genesis fit in with any of these "reconciling" theories?

"So God created man in His own image, in the image of God created He him; male and female created He them" (Gen. i. 27).

Dr. Woods Sinyth argues that as "male and female" are mentioned, although nothing is here said of Eden, where Eve was formed from the side of Adam, it cannot be the same creation as in chapter ii. But the simple explanation is that in chapter $i$. we have a general statement of the origin of man, while we have detailed particulars in chapter ii. The narrative of the six days' creation must have been Divinely revealed to our first parents. The second narrative, which begins at Genesis ii. 4, is quite probably Adam's own account, as related to his children. No doubt both narratives were as well known to Adam's family as the Lord's Prayer and the Apostles' Creed are to us : in the earliest days it was the sum total of all the knowledge the human race possessed, and even if 
no written language then existed it was easily remembered.

"And God said, Let us make man in Our image, after Our likeness : and let them have dominion." How can it for a moment be imagined that these words were spoken of an "earlier race," who would not have those higher and spiritual gifts which Adam was to possess? And then does not the grant of dominion over the fish, and the fowl, and the beasts of the earth accord entirely with what we read in the second chapter, of Adain giving names to them all? And when we read in verse 27 that "God blessed them, and God said unto them, be fruitful and multiply, and replenish the earth, and subdue it," how can we say that the words could possibly apply to an " earlier race," which was to be set aside when Adam was created, and which was eventually to die out, and make way for his descendants?

Then, when we come to the opening words of the fifth chapter, we see the almost literal quotation from Genesis i. 27, and, as Rotherham remarks in his Emphasised Bible, the narrative simply folds back on the previous one, and proves that "man" there and "man" here are the same race.

We have, indeed, only to turn to the plain words of the early chapters of our Bible to see that any "reconciliation" of Science with Scripture founded on the supposition of two different creations of man is utterly untenable.

With reference in general to the two first chapters of the Bible, it is no doubt true, that there are some faithful and earnest teachers who, while they certainly hold most clearly the full inspiration of God's Word, yet appear to think it possible that the words of Genesis may be consistent with the doctrine of the evolution of the body of man from an animal stem, 
and that we may read the Bible narrative of man's "creation," as recording only a Divine interposition which made him a spiritual being. Some writers dwell on the fact that in Genesis ii. 7, instead of the word " created," we have the statement that Adam was "formed" of the dust of the ground, and that God " breathed into his nostrils" the breath of life. But we turn again to the account of man's origin which we have in the first chapter: "So God created man in His own image, in the image of God created He him ; male and fomale created He them " (Genesis i. 27). Is not this threefold use of the word "created" a very strong reminder, at all events, of man's threefold nature, "spirit and soul and body" (1 Thess. v. 23)? And the "second narrative" of creation must clearly be read in conjunction with the narative in the first chapter. What has been said in these pages may perhaps show the difficulties involved in any plan of reconciling Scripture with any theory of human evolution.

\section{The Theory of Evolution.}

As this book is intended chienly for students, :t will be well now to give briefly the chief facts and arguments relied upon for the theory of Evolution, with a simple explanation of some of the terms used by writers on the subject, for those who have not had time to study it closely.

The literature of Evolution is now cnormous. It is in several languages-German, French, Dutch, and Italian, as well as in English. Several of the most important books are very expensive; some are only to be scen in the British Muscum Library: some American books cannot be found there; and of many foreign works there are no translations. There are some small and cheap treatises, but they are written by strong advocates of the evolutionary 
theory, and many of the cheapest books are brought out by the Rationalist Press Association with the avowed object of antagonism to Christian doctrine.

The young student is therefore in no position to read up the whole subject carefully, and to judge the questions involved impartially.

Let us understand clearly in the first place that, although Evolution is constantly referred to by popular writers as if it were one of the most assured facts of Science, it is acknowledged nevertheless that it is still only a Theory.

In August, 1905, the late Sir G. H. Darwin, son of Charles Darwin, presided at the meetings of the British Association for the Advancement of Science at Cape Town, and a paragraph in his Presidential address said :-

"We may liken the facts on which theories of evolution are based to a confused heap of beads, from which a keen-sighted searcher after truth picks out and strings together a few which happen to catch his eye, as possessing certain resemblances. Until recently, theories of evolution in both realms of Nature were partial and discontinuous, and the chains of facts were correspondingly short and disconnected. At length the theory of Natural Selection, by formulating the cause of the divergence of forms in the organic world from the parental stock, furnished the naturalist with a clue by which he examined the disordered mass of facts before him, and he was thus enabled to go far in deducing order where chaos had ruled before, but the problem of reducing the heap to perfect order will probably baffle the ingenuity of the investigator for ever."

And Professors P. Geddes and J. Arthur Thomson, in Evolution, in the Home University Library, say: "It must be remembered that the Evolution 
idea cannot be logically demonstrated. It is not a simple induction from particulars, thoroughly as particulars support it. It is a way of looking at the becoming of things; and it is the only scientific model interpretation that has been suggested. It is a formula that fits the facts, and the facts if fits are its 'evidences' " (p. 67).

The Origin of Species, in. which Darwin propounded his theory of Natural Selection, was published in 1859. Darwin was a most patient observer of Nature, and a most diligent collector of facts, and his works are crowded with interesting and important information about the natural world, whatever we may think of his theory. Fivery book sil Evolution refers to The Origin of Species as a storehouse of material, and it is a book with which every student should be acquainted.

Darwin's theory depends on certain facts about which there is no dispute:

1. That individuals of every species, both plants and animals, increase enormously if there are to checks to their multiplication. (Multiplication of Iife.)

2. That probably no two individuals of any species are exactly alike. (Variation.)

3. That there is a tendency for those inevitable slight variations to be transmitted from parent to offspring. (Heredity.)

4. That in the competition for space and food the individuals best adapted to their surroundings are more likely to survive and perpetuate their species than the rest.

5. That those individuals also which are best fitted to escape from their natural enemies are the most likely to survive. (The Struggle for Existence.)

6. That great changes have been wrought in the course of years in various species by cultivation in 
our vegetables and fruit, and by breeding in several of our domestic animals. (Artificial Selection.)

Upon these admitted facts Darwin founded his theory of Natural Selection. The argument is that, as we know that considerable changes have been brought about in plants and animals by Artificial Selection-by the efforts of cultivators and breeders - similar and much larger changes may have been caused by natural means in the course of ages.

Dr. Wallace says, in The World of Life: "Perhaps the most universal fact-sometimes termed "law"--of the organic world is, that like produces like-that offspring are like their parents. . . . In its widest sense as applied to species there are no exceptions. Not only does the acorn always produce an oak, the cat a kitten, which grows into a cat, the sheep a lamb, and so throughout all nature, but each different well-marked race also produces its like. We recognise Chinese and Negroes as being men of the same species as ourselves, but of different varicties or races, yet these varicties always produce their like, and no case has ever occurred of either race producing offspring in every respect like one of the other races, any more than there are cases of cart-horses producing racers or spaniels producing greyhounds" (p. 102).

Clearly, then, if we are to believe that some species have arisen by inheritance from other species, the burden of proof rests with the Evolutionists.

\section{Science Ripe for Darwin.}

The Making of Species says: "Darwin's theory was enunciated at the psychological moment, at the time when zoological science was ripe for it. Most of the leading zoologists were evolutionists at heart, and were only too ready to accept any theory 
which afforded a plausible explanation of what they believed to have occurred.

"Hence the rapturous welcome accorded to the theory of natural selection by the more progressive biologists.

"Another point in Darwin's favour was the delightful simplicity of his hypothesis. Nothing could be more enticingly probable. It is based on the massailable facts of variation, heredity, and the tendency of animals to multiply in numbers. Everybody knows that the breeder can fix varieties by careful breeding. Darwin had simply to show that there is something in nature to take the part played among domesticated animals by the human breeder. 'This he was able to do. As the numbers of species remain stationary, it is evident that only a simall portion of the animals that are born can reach maturity. A child can see that the animals most likely to survive are those best adapted to the circumstances of their life. Even as the breeder weeds out of his stock the creatures not suited to his purpose, so in nature do the unfit perish in the evcrlasting struggle for existence. : .

"The nineteenth century was a superficial age. It liked simplicity in all things. If Darwin could show that Natural Selection was capable of producing one species, men were not only ready but eager to believe that it could explain the whole of organic evolution" (pp. 4,5).

Professor St. George J. Mivart, whose views are referred to in several places in the Origin of Species, says in his Groundroork of Science:-

"Mi. Darwin was most exceptionally fortunate in the character of his hypothesis, for it was of such a nature as to be almost incapable of disproof. Having taken up the position that every characteristic of a species exists through its utility to that species, and that it may be assumed to have so 
originated unless proof to the contrary can be given, his opponent was thereby reduced to sore straits indeed.

"The Darwinian is free to invole climatic changes, geographical modifications, and the presence or absence of rivals or of enemies at his will and discretion. Easy, indeed, is it for such a one, with some flexibility of imagination, to construct suggestions of utility when provided with such an unlimited field of free speculation. Let an animal be black, and reasons can very readily be found to show blackness may have saved it from destruction. Let it be shown to be white, and another set of reasons are easily imagined to show that the snowier its tints, the more assured are its chances of survival. 'Thus, upon a rabbit's white tail being adduced as a character dangerously conspicuous, it has been replied, 'Oh, but it serves as a signal in danger to guide the young on their way to the burrow.'

"Perhaps the most notable character of the Darwinian theory is the extraordinary easiness of its advocacy and difficulty of its refutation, quite apart from any question of its truth. The chances of its author in such a game of biological speculation can only be expressed by the well-known vulgarism : 'Heads I win, tails you lose.' '

\section{Wallace and Haeckel.}

Two scientific men who are very widely known took up Darwin's theory, but expounded it in ways entirely different: Dr. Alfred Russel Wallace in England, and Professor Ernst Haeckel, of Jena, in Germany. We have already several times quoted passages from their books.

Dr. Russel Wallace is recognised as the co-discoverer with Darwin of the theory of Evolution by 
Natural Selection. Both wrote preliminary essays to the same effect in 1858, and submitted them to the Royal Society, and it was left to Darwin as the older man, and the one with more leisure, to pursue the subject, and in 1859 The Origin of Species was published.

Dr. Wallace in his Darwinism, and especially in his latest work, The World of Life, shows that a purpose runs throughout all Nature, and he argues that this is proof of a Divine intelligence governing the whole. Not that the Divine Creator and Ruler he thought of is the God of the Bible-he could not imagine a God who cares for the infinitely littlehe supposed that such a small speck in the universe as our earth would be left to the care of some angelic being: but he was convinced that the evidences of design and purpose shown in the world's history clearly indicated a supermatural guidance and control.

We have-seen that Dr. Wallace also argues that man's intellectual and moral nature can only have come from the "world of Spirit."

Professor Haeckel, on the contrary, in taking up the Darwinian theory, gave it an entirely materialistic interpretation. His system is an entire denial of any Supreme Creator or Governor of the Universe. His works have been translated and very widely circulated amongst the working classes of this country by the Rationalistic Press Association.

His scheme is propounded in Die Welträthsel, the Riddle of the Universe.

It teaches that the whole universe is a machine, and a machine the various parts of which are continually being disintegrated and continually renewing themselves by an automatic principle of Evolution through endless cycles of time. He denies that man has a higher nature of any kind : the mind of man is merely an emanation from his bodily struc- 
ture. Man has therefore no free will, he is an automaton, and all his acts are pre-determined by his ancestry and his environment. This system of teaching is called Monism, because it declares that there is only one substance in Nature-all is material. It is opposed to Dualism, which recognises not only the material, but also the spiritual.

According to Haeckel, this evolution of the Universe has been going on from everlasting, and will go on for everlasting according to the same principles of decay and renewal in its several parts.

Another thing that he teaches is that the Universe is infinite. Of course this idea is one that the human mind cannot grasp : our minds are finite, and in any mental conception we have of the universe we cannot think of it except as having a limit. It is possible, of course, to speak or think of the stars being infinite in number, and occupying infinity, but we do not possess mental powers capable of grasping the idea.

God is infinite-Eternity is infinite: we can believe these truths, but we cannot fully grasp them. The universe cannot be infinite, because God created it, and $\mathrm{He}$ alone is infinite.

\section{Multiplication of Life.}

LET us now look at the points in Darwin's argument more in detail.

The individuals of every species, both of plants and animals, increase enormously if there are no checks to their multiplication. Darwin says: "There is no exception to the rule that every organic being naturally increases at so high a rate that, if not destroyed, the earth would soon be "covered by the progeny of a single pair."

As Guenther says: "A species that only produced six young in the course of its life would 
increase to fifteen million individuals in the course of 500 years."

The slowest breeding animal is the elephant, but Darwin calculated that in 750 years each pair, if all their oftspring lived and bred, would produce nineteen milions of elephants.

Of several kinds of birds-redbreast, sparrow, thrush, blackbird, etc.-a single pair, if allowed to live and breed, unmolested, for ten years, would increase to more than twenty millions.

The rabbit increases very rapidly, and Mr. Kearton calculates that, under the most favourabie conditions, a single pair might in four or five years increase to a million.

Weismann says: "The female herring brings forth 40,000 eggs a year, the carp 200,000 a year, and the sturgeon two millions, and both species live long, and remain capable of reproduction for at least fifty years."

A single cod can lay over nine million eggs.

In the lower orders the increase is especially rapid. One kind of fly produces 20,000 larvæ, and these grow so rapidly that they can reach their full size in five days; each parent fly may be increased ten thousand-fold in a fortnight. The eggs of tapeworms and other parasitic worms may be counted by the million.

Guenther tells us that the eggs of parasites number 100 millions.

The article Zoology in the Encyclopadia Britannica tells us that in some cases a pair of animals produce ten million offspring.

"And so in the vegetable world," says Dr. Wallace, "a full-grown oak or beech tree is often laden with fruit on every branch, which must often reach 100,000, and sometimes, perhaps, a million in number, each acorn or nut being capable, under 
favourable conditions, of growing into a tree like its parent."

And Goodrich says : "It has been calculated that a single cholera bacillus would give rise to sixteen hundred trillions of bacilli in a day if propagating freely, forming a solid mass weighing 100 tons" (Evolution, p. 52).

\section{The Struggle for Existence.}

As there is such a superabundance of plant life and animal life produced, only an extremely small proportion of the individuals that come into the world can grow to maturity.

As the article Zoology in the Encyclopadia Britannica tells us, while in some cases a pair of animals produce ten million offspring, yet on the average only two survive.

There is thus a continual struggle for existence going on : there is a competition for food, for water. for space, for light; multitudes are destroyed by enemies, or are the victims of disease; multitudes of others perish through floods, or through drought, or from cold, or generally from unfavourable climate. Those which survive, unless destroyed by accident, will usually be those which are best fitted for their surroundings.

In the geological ages vast numbers of species of animals became extinct. Change of climate and consequent lack of food were perhaps the chief causes.

Dr. Wallace, in chapters xi. and xii. of The World of Life, gives some interesting details as to enormous reptiles that lived upon the earth in the Secondary and Tertiary periods-some of them 50 , 60 , and 80 feet in length, and over 10 feet in height-and discusses the causes of their extinction. The cold of the Glacial period accounted for some, but he thinks that there must have been 
other reasons. Such immense creatures would no doubt often have found it difficult to obtain suffcient food, and their movements were probably too slow to escape from enemies.

Many species of animals have become extinct within living memory. Dr. Wallace instances the Passenger Pigeon of North America. A century ago there were believed to be 2,000 millions in Ohio, Kentucky, etc., and they are said to have been reduced to a single pair. Of the American bison, only a small and dwindling herd in Yellowstone Park remains. The Norwegian lemming, a small animal like our short-tailed field mouse, is also disappearing (The World of Life, pp. 115-119).

The cause of the destruction of some animals is not far to seek. Modern forestry is destructive of the wealth of bird-life, as the thinning of trees and brush deprives birds of their nesting-places.

Damp is a great enemy to rabbits, and a wet winter causes much mortality amongst them. They have increased so enormously in Australia greatly because of the dry climate. The introduction of goats into St. Helena led to the entire destruction of the native forests, the young plants being devoured by the goats as fast as they grew up. The camel is a still greater enemy to woody vegetation, and this is said to account for the Arabian and African deserts. The large brown rat has almost entirely driven out the black rat, which was formerly the common rat of Europe. In Australia the imported hive-bee is exterminating the small stingless native bee.

We can quite understand, in the immense destruction of life which must take place in nature, that it will be the animals which are most adapted to their surroundings which will survive, also those which can most easily eseape from their enemies. 
It is the slowest hares which will be eaten by the foxes : the fleetest will escape.

Fuller information can be found in The Origin of Species (chap. iii.), Dr. Wallace's Darwinism (chap. ii.), and E. S. Goodrich's Evolution (chap. v.).

\section{Variation.}

WE can readily understand what variability in nature means, when we look at the men and women we meet with in our streets at home; still more those we might see in some oriental town where East and West are brought together. Is anything more wonderful than the varieties of feature and complexion which are to be found in the small space occupied by the human face? and these same differences would be found in all parts of the body.

"No two human beings," says 'T. V. Wollaston, "ever have existed, or ever will exist, who are absolutely alike in every part and combination of their structure."

Have we ever thought what an extremely inconvenient state of things it would be if we were all exactly alike?

Now this variability obtains throughout ali nature.

"Grains of sand," as Guenther says, "seem alike to us: it takes a lens or microscope to see that not one of them is exactly like another."

"Our ignorance of the laws of variation is profound," says Darwin. And Samuel Butler, the author of Evolution Old and New, says: "To me it seems that the Origin of Variation, whatever it is, is the only true Origin of Species, and of that origin not one of us knows anything." 


\section{Biometry.}

THIs is quite a new science, and its function is to measure all kinds of organisms, and to ascertain the degrees of variation in different parts of the structure of each.

Dr. Wallace in his Darwinism gives us details of measurements of the different parts of lizards, snails, sea anemones, butterflies, moths, earthworms, sparrows, blackbirds, and other birds, and of some plants.

Biometry deals with the exact measurement of differences in plants and animals of all kinds : the length of leaves, the number of petals in flowers, the number of veins in different kinds of beech leaves; the length of the wings, tails, legs, and toes of birds; the variations in the skulls of variors animals; the variations in size of different parts of lizards, beetles, etc.; and measurements have also been made of the human body.

The cause of these variations of structure in ail living beings is one of the most fruitful subjects of discussion in treatises on biology.

The Popular Science Monthly for June, 1911, contained an article on The Measurement of Natural Selection, by Dr. J. Arthur Harris, of the Station for Experimental Evolution, Cold Spring Harbor, New York. After giving the results of many experiments on insects, birds, crabs, snails, fruits of different kinds, etc., he says : "Lpon the application of biometric methods, many supposedly valid biological theories have shrunken to nothing. Possibly this may ultimately be the fate of the natural selection theory. . . Like other theories, the Darwinian theory must stand or fall according as the evidence of quantitative biology shall be for or against it." He says that natural selection "re- 
mains largely a hypothesis, weakly reinforced by analogy and by the indirect evidence of adaptation."

\section{Artificial Selection.}

I' $\mathrm{r}$ is a well-known fact that great changes have been wrought by cultivation in the course of years in many of our vegetables and fruits, and by breeding in several of out domestic animals.

"It is in this way," says Dr. Wallace, "that our race-horses, our best milking cows, our heavy woolled sheep, our quickly fattening pigs, our luscions pears and peaches, and hundreds of others have been produced."

"There are varieties of pigeons," says R. H. Lock, "like the carrier, pouter, fantail, tumbler, which, if they were found existing in a wild condition, would be placed in separate genera by any ornithologist. The domestic races of dogs, horses, cows, sheep, fowls, and cattle show scarcely less divergence." And, as Kellogg says, "a greyhound, a bull-dog, a dachshund, a tumbler pigeon, and a race-horse have had to pass througli a long series of changes in the most varied organs in order to reach their present form, and yet all these variations have appeared one after the other in such a way as never to endanger the vital vigour, for man would never have chosen weakly animals for breeding purposes" (Dareinism To-day, p. 177).

Of course all these changes in plants and animals have been brought about by cultivators and breeders taking advantage of the variations that presented themselves from time to time, and selecting, for reproduction of the species, those individuals which varied in the direction desired. The race-horse and the greyhound owe their origin to breeders continually choosing the fleetest animals for breeding purposes. An enormous 
amount of interesting information on this subject will be found in Darwin's important work, The Variation of Animals and Plants under Domestication.

\section{Natural Selection.}

UPON these acknowledged facts, the rapid multiplication of life, the consequent struggle for existence that is always going on, the variability of all organisms, and the further fact that man by cultivation and breeding has so greatly modified many plants and animals that unless we knew their origin they wonld be reckoned as entirely new species, Darwin, in his Origin of Species, bnilt up the theory that all existing organic life has arisen, in the course of untold ages, by descent from the simplest forms, through natural means, so that what man has done purposely, Nature has done on a vaster scale without aim or purpose. Dr. Archdall Reid says: "Man has caused the evolution of speed in the greyhound and racehorse by breeding, on the whole, from the swiftest animals of each species; in like manner carnivora have caused the evolution of speed in the hare and the antelope by permitting, other things being equal, only the swiftest to continue the race." Darwin believed that the giraffe is the descendant of an ordinary hoofed quadruped, but that in some times of dearth the individuals born with the longest necks were the only ones that survived, as it was only those that conld browse on the higher branches of the trees.

What this theory of Natural Selection teaches is that the earlier forms of life varied in such a way that some were more fitted to live in their surroundings than others, and that the unfit ones perished, and this happened again and again, and that gradual modifications of structure took 
place through long ages, until quite new forms were evolved. Herbert Spencer called this principle, "The Survival of the Fittest," but it has been remarked that a truer description would be "The Elimination of the Unfit."

Of course, seeing what has been accomplished by man through Artificial Selection, we can understand that this process of evolution may have taken place in many cases; the difficulty is to apply the theory universally.

\section{Selective Value.}

TIIE all-important limitation in regard to the theory of Natural Selection, is that at each successive step any variation of structure should be of such a character that it would have selective value, that is to say, that it should be such a variation that it would lead to its possessor or possessors being preserved, while other individuals of the species died.

Darwin's whole argument in the Origin of Species is built on the assumption that all the changes in structure by which species have been modified so as to produce other species have been changes useful to their possessors. He says most distinctly that if it could be proved that "organic beings have been created beautiful for the delight of man" it would be subversive of his whole theory (Origin of Species, ch. vi.).

\section{Limitations.}

BUT let us notice one or two limitations. First of all, as regards the "Struggle for Existence," Kellogg points out that the tremendous competition between! thousands or millions of eggs or embryos must be largely over before the individuals come to maturity, and especially is this true of all species that live for a long time in 
imnature stagcs. Then millions of insects and fishes perish from accidental causes which have nothing whatever to do with their individual fitness or unfitness. He says._- "What after all determines just what millions of trouts' eggs shall be destroyed and what thousands shall hatch sinall fry?... Chicfly chance, the luck of position, the good fortune of not being devoured by the roaming things that paddle or crawl in the upper reaches of tront streams. What shall deciac when a big whalc opens his mouth in the midst of a shoal of inyriads of tiny copepods floating in the pelagic waters of the Alcutian seas, what copepods shall disappear for ever? Mainly, we may say, the chance of position." (Darimism To-day, 1). 81).

His argunent is, that in the rast majority of cases, amongst the lower organisms at all events, variations of structure of the individuals can have 10 influcnce as to their preservation.

Then there are very clear limitations in Variation, and this is proved by the results of Artificial Selcction. Mcssrs. Dewar and Hinn say : "Variations do not always occur equally in all directions. The results of many years of the efforts of practical breeders demonstrate this. These men have not been able to produce a green horse, a pigeon with alternate black and white feathers in the tail, or a cat with a trunk, for the simple reason that the organisms upon which they operated do not happen to have varied in the required direction." Neither have they produced a blue rose, nor a cat that caunot scratch.

"If it were possible absolutely to originate anything by selection, horticulturists would almost certainly ere this have produced a pure black flower. The fact that not a single mammal exists, either in nature or under domestication, with scarlet, blue, 
or green in its hair, appears to show that, for some reason or other, mammals never vary in any of these directions. . . . No one has succeeded in breeding a dog as large as a horse, or a pigeon with a beak as long as that of a snipe. Race-horses seem to have reached the limit of speed" (The Making of Species, pp. 61-69).

We thus see that Variation is limited as to the kind of changes that can be produced in an organism, and as to the extent to which special features of the organism can be carried.

$T$. Vernon Wollaston says in regard to such limitations:- "Variation may have full play, and be by us undefinable, and yet positively restrained within the limits which were imposed upon it originally for each separate species; and therefore, conversely, a species may be indefinitely plastic, and yet remain true to its type." (Coleoplera Atlantidum, p. 39).

\section{What is a Species?}

DARWIN's first great difficulty in The Origin of Species was to answer the question, "What is a Species?" and from the wide differences of opinion amongst naturalists he practically found it impossible to frame any rule to distinguish between a Species and a Variety.

Different writers have different systems of classification, and the article Zoology in the Encyclopcedia Britannica gives several examples of those employed for the animal kingdom. It is ustial now to speak of the Phylum, the Class, the Order, the Family, the Genus, and the Species. But in a species there are many Varieties, and we sometimes hear of the Sub-Species.

Iinnæus, who lived before the days of evolution (Systema Naturce, 1737), considered those as species 
Which were so created in the beginning, and Agassi\% (On the Plan of the Creation, 1846) maintained not only that each species was separately created, but that it was created in the localities in which it is now found.

As a general rule, the varicties of any one species can breed together, and their mongrel offspring arc fertile when bred among themselves, while distinct species are usually infertile when crossed, and their hybrid offspring, as in the case of the mule, absolutely sterile. This used to be considered the criterion of a species as distinct from a variety,..but Darwin contends that there is 110 such fixed law in nature. This question of the sterility of Hybrids is one very largely discussed in several of the books on Evolution.

\section{How Many Species?}

As to the number of species there can only be estimates, and naturally these differ widely when there is no general agrecment as to the definition of a Species.

Messrs. Dewar and Finn say: "So vast is the field of biology that nowadays biologists are compelled to specialise to some extent. Thus we have botanists, ornithologists, those who devote themselves to the study of mammals, those who confine themselves to the reptiles, or insects, or fishes, or crustaccans, or bactcria, etc. Now cach class of systematists has its own particular criterion of what constitutes a Specics" (The Making of Species, p. 89).

Rev. E. Wasmann says: "In the year 1901 the total number of species of animals known to science amounted to at least 500,000 -of which more than half are inscets. In giving the number of species of bectle at 100,000 we are probably rather under- 
stating it. In the vegetable kingdom it is estimated that there are about 200,000 species scientifically described, divided into 11,000 genera-there are 50,000 species of cryptograms alone." He also says that 4,000 species of ants have been described (Modern Biology, p. 20).

Weismann speaks of 200,000 species of insects, and 80,000 fossil species. Kellogg says: "It is wholly certain that the number of different species, that is, kinds of living organisms, must number millions. Of the extinct species, those hosts of changing denizens of our earth in the ages gone, the number of recorded forms can at best be the reriest fraction of the grand total" (Darinism Today, p. 10).

He further says: "For the insects alone entomologists have estimated that over two million species must be in present existence" (p. 22).

Dr. Wallace gives an estimate from the Natural History Museum of 240,000 species of insects actually described, and adds a further estimate by Mr. A. E. Shipley, F.R.S., of a total of 790,000 described species of living animals, 450,000 of these being insects (The World of Life, p. 92).

Professor P. C. Mitchell, in his article Evolution, in the Encyclopedia Britannica, mentions a proposal that has been made to institute a division between Master species for such species as have been properly revised by the comparative morphologist, and Provisional species for such species as have been provisionally registered by those working at collections (Vol. x., p. 35).

The number of animals of various species that have become extinct during the geological ages is immense.

Dr. Wallace says that " the totality of the species that have lived upon the earth must be very much 
more than tweive times-perhaps even thirty or forty times-the number now living " (Darinism, p. 377).

At some periods in the geological story immense numbers appear rather suddenly, and Dr. Driver's rendering of Gen. i. 20: "Let the waters swarm with swarms of living creatures" is spoken of by several writers as being specially appropriate.

Several species amongst the lower orders of living beings seem to have remained almost unchanged from the time of the earliest strata which contain organic remains until the present time. The lingula, a small shell-fish, one of the Brachiopoda, is an organism that appears to have remained constant in structure from the earliest geological times (Masterman's Zoology).

On the other hand, Dr. Wallace tells us that "not a single new species is known to have come into existence during the whole of the Pleistocene period," that is, the geological period preceding the one in which we live (World of Life, p. 257).

The existing species of Nautius, and our crickets, and ant's, and water-fleas, and many forms of shell-bearing molluscs, and a genus which includes our common limpet, are also mentioned by various writers as having changed very little through long geological periods.

Whether any new species has come into existence during historical time is a question which is much debated. The representations of animals and plants, shown on the Egyptian monuments, or embalmed, are closely similar or even identical with those now living.

Sir J. W. Dawson says: "No case is certainly known in human experience where any species of animal or plant has been so changed as to assume 
all the characters of a new species" (The Origin of the World, p. 227).

But there are a few cases in which it is claimed that new species are known to have arisen in recent times. The case of the Porto Santo rabbits is one in point. About the year 1419 a femalc rabbit had a litter of young on board a Spanish ship, and they were turned loose on the island of Porto Santo, near Madeira, and some of their descendants, brought to England some years ago, were found to be so different from ordinary rabbits that if they had been found in some remote country they would have been described as a distinct species.

Another case is that of the Evening Primroses, found by Professor Hugo de Vries, at Hilversum, near Amsterdam, which are said to produce a number of new species every year, and de Vries cites several instances of other plants. Of course, the question is whether the new forms can rightly be called Species, or whether they are only Varicties.

On this subject Kellogg writes: "We only tell the general truth when we declare that no indubitable cases of species-forming or transforming, that is, of descent, have been observed; and that no recognised case of natural selection really selecting has been observed. I hasten to repeat the names of the Ancon sheep, the Paraguay cattle, the Porto Santo rabbit, the Artemias of Schmankewitch, and the de Vriesian Evening Primroses to show that I know my list of classic possible exceptions to this denial of observed species-forming, and to refer to Weldon's broad-and-narrow-fronted crabs as a case of what may be an observation of selection at work. But such a list, even if it could be extended to a score, or to a hundred, of cases is ludicrous as objective proof of that descent and selection under whose domination the forming of millions of 
species is supposed to have occurred" (Darainism To-day, p. 19).

If all this be true, the only proofs of cvolution have to be looked for in the geological record, and in this before the Pleistocenc period.

\section{The Limits of Evolution.}

WHAT are the limits of Evolution? If there is truth in the theory, to what extent is it true?

The term evolution was applied by Herbert Spencer to the manner in which the stars and other heavenly bodies are supposed to have arisen, to the geological strata and geographical configuration of the earth, and to the various gradations of human Society.

Dr. Arthur 'Thomson says: "It is convenient to speak of 'cosmic cvolution,' 'inorganic evolution,' 'the evolution of the solar system,' 'the evolution of the earth,' 'the evolution of scenery,' and so on, but there is a risk of identifying processes which are really very different" (The Wonder of Life, p. 636).

Hacckel's works propound a theory of evolution starting from the original cosmic vapours and ending with the human race, and Mr. Joseph McCabe, his disciple and translator, has a theory very similar in his book, Evolution from Nebula to Man.

But Darwin was quite opposed to the doctrinc of Abiogenesis, or Spontaneous Generation: that is, the theory advocated by Professor Schäfer in his Presidential address at the meeting of the British Association at Dundee in September, 1912, of the evolution of organic life-the life of all plants and animals-from the inorganic world of rocks, minerals, etc.

Organic Evolution, of which the Origin of Species treats, has to do with organisus-with the 
coming into existence of the various species of animals and plants.

All living organisms, of any kind whatsoever, may be regarded as composed of protoplasm, or of substances or structures produced by the protoplasm : hence protoplasm is described as the physical and material basis of life.

Huxley said, in his article, Biology, in the ninth edition of the Encyclopadia Britannica: "If all living beings have been evolved from pre-existing forms of life, it is enough that a single particle of living protoplasm should have once appeared on the globe, as the result of 110 matter what agency. In the eyes of a consistent erolutionist any further independent formation of protoplasm would be sheer waste."

Darwin, in his Origin of Species, did not carry his theory so far as to derive all living beings from the one speck of protoplasm. What he said was: "I believe that animals are derived from at most only four or five progenitors, and plants from an equal or even lesser number. Analogy would lead me one step further, namely, to the belief that all animals and plants are descended from some one prototype. But analogy may be a deccitful guide" (Chap. xv. conclusion).

By the "four or five progenitors," Darwin presumably meant some of the lowest organisms, the Protozoa, or one-celled animals, of whom the bestknown is the Amoba. This is a common microscopic object, just visible to the naked eye as a little speck of floating jelly.

In The Origin of Species, which was brought out in 1859, Darwin said nothing as to the Evolution of mankind from the animal. He propounded this extension of his theory in The Descent of Man, published in 1871. 
Darvin certainly had no intention by his theories of denying the Creator: the closing words of the Origin of Species are: "There is a grandeur in this liew of life, with its several powers, having been originally breathed by the Creator into a few forms or into one; and that, whilst this planet has gone cycling on according to the fixed law of gravity, from so sinple a beginning endless forms most beautiful and most wonderful have been, and are being erolved."

And, in a paragraph, just preceding, he speais of "the laws impressed on matter by the Creator."

Neither can we say that he attributed everything to chance, though the majority of writers, in speaking of his theory, look upon chance as the mainspring of his system. If he spoke of "chance variations," it wonld seen that he imagined that some future discovery might show that these variations were, after all, regulated by some natural law. It is a question whether Mendelism, if we accept all that its advocates claim for it, does not come very near to the discovery of this natural law.

In The Descent of Man, indeed, Darwin expressly repudiated the doctrine of chance. He said: "The birth both of the species and the individual are equally parts of that grand sequence of events, which our minds refuse to accept as the result of blind chance. The understanding revolts at such a conclusion, whether or not we are able to believe that every slight variation of structure-the union of each pair . . . and other such events, have all been ordained for some special purpose" (p. 937).

\section{The Relation of Organic Beings.}

WE may now look at some of the arguments which have been brought forward as proofs of the theory of Evolution. 
In his summary of the fourth chapter of The Origin of Species, Darwin says: "It is a truly wonderful fact-the wonder of which we are apt to overlook from familiarity - that all animals and all plants throughout all time and space should be related to each other in groups, in the manner which we everywhere behold-namely, varieties of the same species most closely related, species of the same genus less closely and unequally related, forming sections and sub-genera, species of distinct genera much less closely related, and genera related in different degrees, forming sub-families, families, orders, sub-classes, and classes. The severa! subordinate groups in any class cannot be ranked in a single file, but seem clustered round points, and these round other points, and so in almost endless cycles. If species had been independently created, ino explanation would have been possible of this kind of classification; but it is explained through inheritance and the complex action of natural selection."

Anyone who has not spent a lifetime in biological studies can, perhaps, not fully appreciate the force of this argument.

Professor Kölliker, of Wurzburg, however, in his essay Upon the Darwinian Theory, answered this. He said: "Darwin forgets that inorganic nature, in which there can be no thought of genetic connection of forms, exhibits the same regular plan, the same harmony, as the organic world; and that, to cite only one example, there is as much a natural sustem of minerals as of plants and animals."

This is quoted in Huxley's Criticisms on the "Origin of Species" in Lectures and Lay Sermons.

Huxley's reply to it comes to this, that if we knew everything, we might find out that minerals were evolved from one another. And yet he closes 
another essay, on The Origination of Living Beings, by saying that, as a result of the experiments of $M$. Pasteur, "the doctrine of spontaneous generation has received a final coup de grace." If there has been no evolution from the inorganic world, we can hardly suppose there was evolution in the inorganic world.

Then, also, it is very difficult-at all crents for the untutored layman-to reconcile Darwin's words with what we read in other authors of "great gaps" in nature. Dr. Wallace, for instance, in his Darwinism speaks of " the great gaps that separate the mammalia, birds, reptiles, and fishes from each other" (p. 114), and in another place he says: "With such a wealth of material . . We should hope to learn the steps by which some isolated forms have been connected with their nearest allies, and in many cases to have the gaps filled up which now separate genus from genus, or species from species. In some cases these expectations are fulfilled, but in many other cases we seek in vain for evidence of the kind we desire; and this absence of evidence with such an apparent wealth of material is held by many persons to throw doubt on the theory of evolution itself"' (p. 376).

\section{Homologies.}

ONE of Darwin's arguments in favour of evolution is that members of the same class, independently of their habit of life, resemble each other in the general plan of their organisation. "What can be more curious," he says, "than that the hand of a man, formed for grasping, that of a mole for digging, the leg of the horse, the paddle of the porpoise, and the wing of the bat should all be constructed on the same pattern, and should include similar bones, in the same relative positions?"' (Origin of Species, chap. xiv.). 
And in The Descent of Man he says: "The homological construction of the whole frame in the members of the same class is intelligible, if we admit their descent from a common progenitor, together with their subsequent adaptation to diversified conditions. On any other view the similarity between the hand of a man or monkey, the foot of a horse, the flipper of a seal, the wing of a bat, is utterly inexplicable" (p. 35).

But a book has recently appeared by Professor D'Arcy W. Thompson, On Groweth and Form, which throws some new light on the subject. In his epilogue he says that there are certain mathematical aspects of morphology (the science of the forms of organisms) to which as yet the morphologist has given little attention.

Quoting what Sir E. Ray Lankester said in 1873, that "the fact that we are able to classify organisms in accordance with the structural characteristics which they present is due to the fact of their being related by descent," Professor Thompson says: "But this great generalisation is apt, in my opinion, to carry us too far. It may be safe and sure, and helpful and illuminating when we apply it to such complex entities-such thousandfold resultants of the combination and permutation of many variable characters-as a horse, a lion, or an eagle; but (to my mind) it has a very different look and a far less firm foundation, when we attempt to extend it to minute organisms whose specific characters are few and simple, whose simplicity becomes much more manifest when we regard it from the point of view of physical and mathematical description and analysis, and whose form is referable, or (to say the least of it) is very largely referable, to the direct and immediate action of a particular physical force. When we come to deal with the minute skeletons of the Radiolaria we shall again find ourselves dealing 
with endless modifications of form, in which it becoines still more difficult to discern, or to apply, the guiding principle of affiliation or genealogy."

'The reviewer of Professor Thompson's book in the Times Literary Supplement (May 24th, 1917) sags: "Some resemblances-such as, to take an easy example, that between the wing of a bat and the wing of a bee-conld not be due to close bloodrelationship. The zoologist has had to decide that some resemblances, which he calls homologies, are due to relationship, while others, which he calls analogies, are due to.some other cause. Unfortunately, there is no easy way of deciding whether a particular rescmblance is to be regarded as a homology or an analogy."

With regard to the argument of Professor Thompson's book generally, the reviewer says: "In a set of engrossing chapters he discusses innumerable details of animal structure with the object of showing that in many cases these are the inevitable outcome of simple physical forces. They are what they are because, given the nature of the material and the limiting conditions of growth, they could not be otherwise. Rescmblances are the result of similar forces playing on similar material; differences happen when dissimilar forces impinge on the same material, or-which comes to the same thing, as there is no valid difference between force and matter-when similar forces impinge on different material. The zoologist must begin with mathematics; it is only when he has satisfied himself that a form or magnitude, an arrest or a proliferation, is not the immediate consequence of simple and known factors that he is entitled to suggest purpose or design, blood-relationship or its absence."

The well-known Bridgewater treatise by Sir Charles Bell, The Hand, goes fully into the comparison of the hand and arm of man with the cor- 
responding parts of other animals, and he shows the evidences of design in the wonderful adaptation of the human hand to the multitude of actions required of it, and this, "not nuerely as combining the perfections of mechanical structure, but as possessing the property of Touch, by which it adninisters to and improves every other sense, constituting it the organ in the body the most remarkable for correspondence with man's capacities."

This old treatise by Sir Charles Bell, and Professor Thompson's recent volume, On Growth and Form, are the best reply to Darwin's arguments from "Homologies" which appear in several places in his works.

While Darwin uses the expression, "The hand of a man or monkey," it is worth notice that Sir Charles Bell says of the Spider Monkey (Ateles), "The tail answers all the purposes of a hand." Of course, the anthropoids have no tails.

Professor Otto explains the view taken by some German naturalists. He says that Professor A. Kerner, in his Natural History of Plants, "Aisposes of the chief argument in favour of the theory of descent, the homology of individual organs, by explaining that the homology is due to the similarity of function in the different organisms." Then of Professor Hamann and his Entivicklungslehre und Daruinismus, Otto says: "One of his favourite arguments-and it is a weighty one, though neglected by the orthodox Darwinians-is that living substance is capable, under similar stimuli, of developing spontaneously and afresh, at quite different points and in different groups, similar organs, such as spots sensitive to light, accumulations of pigment; eye-spots, lenses, complete eyes, and similarity with the notochord, the excretory organs, and the like. Therefore homology of organs is no proof of their hereditary 
affiliation" (Naturalism and Religion, pp. 112, 123).

Professor St. George Mivart said in his Lessons from Nature: "Experience more and more convinces me that the number of similarities which have arisen independently (i.e., cases of homoplasy) is prodigious, as well as that very great caution is needed in endeavouring to discriminate between likenesses which may be due to inheritance, and those which are due to some other cause" (p. 261).

\section{Geographical Distribution.}

THE distribution of animals and plants of various species over the whole of the world is a deeply interesting study, and we learn from it many facts that are somewhat surprising.

Darwin tells us that his first ideas as to the theory of evolution canne from his observing the different species of birds, lizards, tortoises, etc., in the different small islands of the Galapagos Archipelago in the Pacific, about 600 miles from the coast of Ecuador, in South America, which he visited when engaged as a naturalist on the scientific voyage of the Beagle in 1835. The majority of the birds on these islands are of species peculiar to each island, yet all having an affinity to the birds of South America, and the same is true of the other animals and plants. He concludes from this that the islands were at some date colonised from the Continent, and that the species in each island has varied in the course of time through evolution.

He then shows that the same principle applies in various parts of the world; that vegetable and animal life is not what we might expect it to be if all plants and animals had been created in their present environment; and especially that in some countries like Australia, South Africa, and Western South America, where the conditions as 
to climate, etc., are extremely similar, the life is widely different. He also shows that it is where there are natural barriers to free migration, like oceans or mountain ranges, that countries, although they may be near each other, differ radically in their animal and vegetable productions.

His argument is, of course, intended to prove that different species have come from a common parentage, from one centre of production, and that through evolutionary change they have been modified into their present form.

Then there, of course, comes in the large question as to the means by which the various plants and animals have been dispersed from their original centre to the various parts of the globe where they are now found.

The means of dispersal suggested are various. Birds could no doubt reach distant islands by flight, and so could many winged insects. The seeds of plants might float long distances on the water, or they might be taken on drift timber, or they might be carried in the crops of birds, or in a little earth adhering to the feet or beaks of birds. Icebergs are sometimes loaded with earth and stones, and they may have transported seeds from one part to another of the polar regions. Then the eggs of insects and of reptiles might often have been carried by driftnood, or even by birds. Locusts are sometimes blown to great distances from the land.

The difficulty comes in regard to land animals, which cannot fly. These are not generally found in oceanic islands, which are in the great majority of cases of volcanic origin.

As regards most of the islands of the world, which are now separated from the continents near which they lie by not very deep channels, it is supposed that they were once united to those con- 
tinents, and that their inhabitants reached them before their separation. Dr. Wallace's Darwinism contains a map of the world, giving the portions of the ocean surrounding the various continents where the depth is not more than a thousand fathoms, and this shows that the British Isles, Iceland, the West Indies, the Mediterranean islands, Ceylon, Australia, and the castern Archipelago, and the Philippines, and Formosa, and Japan all come within the thousand fathom line, New Zealand and Madagascar being the only large islands outside it.

The Glacial period is held to account for the identity of many plants and animals on mountain summits, separated from each other by hundreds of miles of lowlands, where Alpine species could not possibly exist.

Then as regards such animals as tapirs, now only found in Malaysia, and in tropical America, we are referred to Miocene and Pliocene times, when they abounded in Europe and Asia. They are supposed to have entered America by way of Kamschatka and Alaska, when that region was warmer.

Darwin freely admits that there are difficulties unsolved. He says: "I do not deny that there are many and serious difficulties in understanding how many of the inhabitants of the more remote islands, whether still retaining the same specific form or subsequently modified, have reached their present homes" (Origin of Species, chap. xiii.).

Then he admits that "although in oceanic islands the species are few in number, the proportion of endemic kinds (i.e., those found nowhere else in the world) is often extremely large." He supposes that the ancestors of these arrived long ago, and were specially liable to modification.

As regards the Galapagos Archipelago, he also admits that it is a surprising fact that each new 
species, after being formed in any one island, dic not spread quickly to the others. $\mathrm{He}$ accounts for this by the fact that the islands are separated from each other by deep arms of the sea, and there is no reason to suppose that they have at any former period been united. This however would hardly' apply to the birds, which he says are "so well adapted for flying from island to island."

But there is a great difference of opinion amongst writers as to the origin of the islands, and most authorities think that the giant tortoises upon thein (of which there are now scven species, and there were formerly fifteen) prove that the islands once formed part of the South American continent. But according to the Encyclopadia Britannica, there is no trace of such tortoises having existed on the mainland.

Dr. Wallace, whose chapter on Geographical Distribution in his Darzinism (ch. xii.) is especially good, also admits the difficulty of accounting for the members of the lizard tribe which are found in almost all tropical oceanic islands, because we are ignorant of the means by which they can have crassed the sea.

\section{Dispersal of Animals.}

THE essay in Darwin and Modern Science on the Geographical Distribution of Animals is by Dr. Hans Gadow, lecturer on Zoology at Cambridge, and he criticises some of the views of Darwin and Dr. Wallace as to the ineans by which animals can have been dispersed over the globe, and speaks of the theory of "flotsam and jetsam" as being sadly deficient, often grotesque, in the case of most terrestrial creatures (p. 323). He thinks that some of the devices proposed for the mechanical dispersal of animals "cannot be held seriously to account for the rich fauna of a large continent" (p. 329). He 
supposes the migration of many kinds of animals to distant parts of the earth to have taken place very far back in geological time, and he appears to favour some of the theories which have been advanced by various writers as to land existing in former ages of the earth's history between our present continents, such as that of a great mass of land during the Jurassic epoch joining Africa and South America, or a junction between Patagonia and the land in the Antarctic circle; though he feels doubtful about the supposition of Haeckel that there was a land he calls "Lemuria" - a bridge for the lemurs to pass over-connecting Africa, Madagascar, India, and the Malay archipelago. But Dr. Wallace emphatically negatives the idea of these hypothetical ancient land connections: he says that there is not a particle of evidence for the bridging of the Atlantic in Southern latitudes (Darwinism, p. 349), and he shows that there are difficulties of another kind. He says: "The fact that the waters of the ocean are sufficient to cover the whole globe to a depth of two miles is alone sufficient to indicate that the great ocean basins are permanent features of the carth's surface, since any process of alternation of these with the land areas would have been almost certain to result again and again in the total disappearance of large portions, if not of all, of the dry land of the globe" (p. 346).

It is clear that the greatest authorities are by no means agreed as to hore it could be possible, if all the species of each genus, according to Darwin's theory, originated in a single centre, that they could have migrated to the different parts of the world where we now find them, and Dr. Gadow says of the recent literature on the subject: "It is a chaos, with many paths leading into the maze, but as yet very few take us to a position com- 
manding a view of the whole intricate terrain with its impenetrable tangle and pitfalls" (p. 328).

We must remember that if the facts of Geographical Distribution can be taken as a proof of Evolution, they can only prove it within limits : Darwin only adduces them to show that each species, or all the species of a genus, proceeded from a single birthplace. This is a long way from the claim that all living beings arose from a single speck of protoplasm.

Dr. Gadow, in his essay, alludes to the views of different authors as to the question of the Multiple origin of species (see p. 324).

Of course, none of these difficulties attend the Bible narrative of creation. The first chapter of Genesis does not tell us whether animals of various kinds were created in one centre or at many different centres. We only learn that the human race have descended from our first parents, who were placed at the creation in the Garden of Eden ; and Huxley sees no difficulty in believing that man might have migrated to all parts of the inbabited world, seeing that each part was accessible to the inhabitants of the nearest country by means which savages are known to have used, and which must have been invented by them (Lectures, etc., pp. 93, 94).

\section{Geological Succession.}

THE succession of fossil forms of different species of animals in past ages is relied upon by Darwin and the naturalists who have followed him as affording some of the most convincing evidences in favour of evolution.

Special instances among the invertebrate animals are brought forward as the clearest cases of succession of forms which show gradual changes, these being ascribed to evolution.

The Steinhein Snails are a classical instance 
(Planorbis Multiformis)-little freshwater suails found in millions in the calcareous deposits of the Tertiary period in a lake basin near Steinheim, in Wurtemburg. Shells that appear to be so different that they would be ranked as distinct species are connected by a long series of fine gradations.

The ammonites are a genus of fossil shells allied to the Nautilus, but found in Palrozoic to Mesozoic deposits; they take their name from a fancied resemblance to the head of Jupiter Ammon. They are said to show five distinct lines of evolution of unequal duration.

Then there are the Trilobites-fossil crustacea found abundantly in seas of the Cambrian and Silurian periods, but disappearing entirely at the end of Palæozoic time.

The Brachiopoda also are shell fish found in shallow waters; about 2,000 species are found in the Silurian deposits, and also in the Devonian. At present they are represented by about 140 species. These are said to follow several distinct lines of evolution. And yet to the Brachiopods belongs the species Lingula. which has come down to us apparently unchanged since Cambrian times.

Then Dr. Wallace speaks in his Darwinism (p. 381) of the discoveries by Dr. Newmayr of forms of the genus Paludina vivipara (the river suail) in the plains of Hungary; the fossils occur in beds of a thickness of 2,000 feet, divisible into eight zones, and they are said to show many connecting links, illustrating the derivation of the newer from the older types.

It is evident, of course, that these instances can only be proofs of evolution within very narrow limits, as the Trilobites remained Trilobites as long as their existence continued, the Ammonites remained Ammonites, and the Snails still remain snails. 


\section{Ancient Fossil Forms.}

DARwin states that when gaps exist between genera, families, and orders of animals now living, ancient fossil forms are often found which appear to be intermediate between them. Supposing distinct groups to be distinguished at the present day by a score of characters, the ancient members are separated by a somewhat lesser number of characters, so that the two groups in fornier times made a nearer approach to one another than they do now. Amongst the instances of this, he mentions that Professor Owen was able to "dissolve by gradations the apparently wide interval between the pig and the camel" (Origin of Species, chap. xi.). But when we turn to Masterman's Zoology, we find that both these animals are classed under the Artiodactyla, which form Sub-Order V. of the Mammalia, so that the interval is not so wide zoologically as it may appear at first sight.

Dr. Wallace, in his Darwinism, shows that fossil forms exist which are to some extent intermediate between our existing crocodiles and lizards. But both of these belong to the Reptiles. Then the rhinoceroses and the tapirs, also cited by Dr. Wallace, are both families of one of the Sub-Orders of the Ungulata (hoofed animals) (p. 383).

\section{Fossil Horses.}

THE pedigree of the horse tribe is brought forward prominently in all books on evolution as convincing proof of the theory, Professor Marsh, of Yale, having traced many fossil forms in North and Sonth America. This pedigree is, however, criticised very sharply by Dr. Albert Fleischmann, Professor of Zoology in Erlangen, in his Die Descendenztheorie (1901), who devotes chapter v. of his book to an examination of the proposed 
genealogy of the fossil horse, ranging from the Eocene to the Pleistocene.

He says: "How have the Equidre been evolved out of the older forms? As an intermediate form we find Merychippus named, and upon this Haeckel and Schlosser lay especial weight. During a stay with Marsh in America the latter had special opportunity to study the remains of Merychippus.

But when we ask what was the outward form of Merychippus, we only get the reply that the teeth were formed after the type of the horse. When we enquire as to the limbs, the skeleton, the skull, we get no information. Nothing is known of Merychippus but the teeth"' (p. 76). His arglment is that descent cannot safely be inferred by tracing one organ alone through several forms, but that the whole skeleton is needed. ('There is a littic doubt whether two different specimens have not been named Merychippus.)

It is acknowledged that the Equine pedigree was not rightly understood at first, as Messrs. Thomson and Geddes say in their Evolution: "In the enthusiasm of early discoveries the matter seemed simpler than it really is, and the mistake was made of hurricdly constructing a linear series. which showed, for instance, the gradual reduction of toes from five to one, and supposing this was a genuine pedigree. More detailed and critical enquiry has shown, however, that there were several collateral series, and it is not quite justifiable to fill up gaps along one line by links which belong to other lines of descent"' (p. 29).

Then they quote Depéret, who says : "The supposed pedigree of the Equidze is a deceitful delusion," and they admit that there are "many puzzles," and that "we are not even now able to state the lineage of the modern horse" (p. 23).

But granting to the full what is claimed for the 
evolution of the horse tribe, it is evolution which keeps within the limits of the Ungulata, the hoofed animals.

Dr. Wallace, in The World of Life (p. 227), gives an account of recent fossil discoveries which are supposed to connect the elephants with other hoofed animals. The great difficulty of Darwin was to account for the trunk of the elephant by natural selection, for of what use could a trunk of short length in process of evolution have been to any ancestor of the elephant? But now some fossil Proboscidea have been found in deposits in Egypt of the Eocene period, and these are supposed to form a connecting link.

\section{Birds and Reptiles.}

If it could be proved that birds were in the first place evolved from reptiles, it would be a somewhat wider extension of the limits of evolution than is shown by the instances we have considered.

The supposed missing link between bird and reptile is the Archæopteryx, a bird about as large as a rook, of which two fossil specimens have been found in the lithographic slate quarries of Solenhofen, in Bavaria. One is in the British Museum, and the other in the Berlin Museum. It has teeth, and a reptilian tail. The majority of the fossil birds of the Cretaceous epoch have teeth, and this has been supposed to connect them with the reptiles. No birds of later than the Cretaceous age are known to have teeth, and recent birds do not possess even embryonic vestiges. (See Encyclopedia Britannica: Odontornithes).

Dr. A. Fleischmann, in the sixth chapter of Die Descendenztheorie, discusses at some length the anatomy of the birds, and especially of the Archropteryx, and strongly contends against the view 
that the latter is a link with the reptiles, citing $K$. Zittel and other naturalists in his support.

It must, of course, be understood that none of these lines of fossil forms can possibly give any proof of the evolution of one form from another, and it is often acknowledged that the evidence of their succession is not clear. The article by Professor H. F. Osborn on Palaontology in the Encyclopadia Britannica says: "From comparative anatomy alone it is possible to arrange a series of living forms which, although structurally a convincing array, because placed in a graded series, may be, nevertheless, in an order inverse to that of the actual historical succession. The most markcd case of such inversion in comparative anatouly is that of Carl Gegenbaur, who, in arranging the fins of fishes in support of his theory that the fin of the Australian lung-fish was the most primitive, placed as the primordial type a fin which palæontology has proved to be one of the latest types, if not the last. It is equally true that palreontological evidence has frequently failed where we most sorely needed it" (Vol. xx., p. 586).

The same article, a little later on, refers to another element of uncertainty when it says that Cope, in his Origin of the Fittest, pointed out "the extraordinary parallelisms between unrelated groups of amphibians, reptiles, and mammals-that is, parallelisms which might raise the supposition that they are related, while other facts prove them to be unrelated"' (p. 589).

Professor Osborn thus sums up the palæontological evidence at the end of his article :-

"The net result of observation is not favourable to the essentially Darwinian view that the adaptive arises out of the fortuitous by selection, but is rather favourable to the hypothesis of the existence of some quite unknown intrinsic law of life which 
we are at present totally unable to comprehend or even perceive."

And then, as regards the extent of the evolution which this palæontological evidence affords, we must clearly see that it bears no testimony to an $u n$ limited evolution. If all the instances brought forward could be proved true, they do not show that all living beings arose from the very lowest forms in nature.

Professor Osborn does not think so, however, for he says: "Were the geologic record complete, he (the palæontologist) would be able to trace the ancestry of man and of all other animals back to their very beginnings in the primordial protoplasm" ( $p$. 587).

\section{Geological Contemporaneity.}

THE evidence of Palæontology in favour of Evolution depends, of course, upon the assumption that we know with sufficient certainty the order in which the stratified rocks have been laid down upon the earth's surface during the geological ages, and that geologists are able to determine which of the strata found in different parts of the world were contemporaneous. But the following extract from Huxley's essay on Geological Contemporaneity and Persistent Types of Life in his Lectures and Lay Sermons (Everyman's Library) shows what uncertainty exists on this subject, which is so important to the evolutionary theory :-

"But it would have been very much better for geology if so loose and ambiguous a word as "contemporaneous' had been excluded from her terminology, and if, in its stead, some term expressing similarity of serial relation, and excluding the notion of time altogether, had been employed to denote correspondence in position in two or more series of strata (p. 24). 
"Whether, after all, it might not be well for palæontologists to learn a little more carefully that scientific 'ars artium,' the art of saying 'I don't know' (p. 25).

"The Iias of England and the Lias of Germany, the Cretaceous rocks of Britain and the Cretaceous rocks of Southern India, are termed by geologists 'contemporancous' formations; but whenever any thoughtful geologist is asked whether he means to say that they were deposited synchronously, he says, 'No-only within the same great epoch.' And if, in pursuing the inquiry, he is asked what may be the approximate value in time of a 'great epoch,' whether it means a hundred years, or a thousand, or a million, or ten million years, his reply is, 'I cannot tell' (p. 27).

"If the further question be put, whether physical geology is in possession of any method by which the actual synchrony (or the reverse) of any two distant deposits can be ascertained, no such method can be heard of ; it being admitted by all the best authorities that neither similarity of mineral composition, nor of physical character, nor even direct continuity of stratum, are absolute proofs of the synchronism of even approximated sedimentary strata; while, for distant deposits, there seems to be no kind of physical evidence attainable of a nature competent to decide whether such deposits were formed simultaneously, or whether they possess any given difference of antiquity. To return to an example already given. All competent authorities will probably assent to the proposition that physical geology does not enable us in any way to reply to this question: Were the British cretaceous rocks deposited at the same time as those of India, or are they a million of years younger or a million of years older? (p. 27).

"Is palæontology able to succeed where physical 
gcology fails? Standard writers on palreontology, as has been seen, assume that she can. They take it for granted that deposits containing similar organic remains are synchronous-at any rate in a broad sense; and yet, those who will study the eleventh and twelfth chapters of Sir Henry De La Beche's remarkable Researches in Theoretical Geology, published now nearly thirty years ago, and will carry out the arguments there most luminously stated to their logical consequences, may very easily convince themselves that even absolute identity of organic contents is no proof of the synchrony of deposits, while absolute diversity is no proof of difference of date. Sir Henry De La Beche goes even further, and adduces conclusive evidence to show that the different parts of one and the same stratum, having a similar composition throughout, containing the same organic remains, and having similar beds above and below it, may yet differ to any conceivable extent in age (pp. 27 , 28).

"There seems, then, no escape from the adnission that neither physical geology nor palreontology possesses any method by which the absolute synchronism of two strata can be demonstrated (p. 29).

"In the present condition of our knowledge ancl of our methods, one verdict-'not proven, and not proveable'-must be recorded against all the grand hypotheses of the palæontologist respecting the general succession of life on the globe" (p. 30).

\section{Uncertainties.}

Axongst prominent writers on Evolution ther are not a few who quite admit that there are many uncertainties about the theory, or about certain important questions in connection with it.

Professor J. Arthur Thomson says: "Briefly and concretely stated, the general doctrine of organic 
evolution suggests, as we all know, that the plants and animals now around us are the results of natural processes of growth and change working throughout unthinkably long ages; that the forms we see are the lineal descendants of ancestors on the whole somewhat simpler; that these are descended from yet simpler forms, and so on, backwards, till we lose our clue in the unknown, but doubtless momentous, vital events of pre-Cambrian ages, or in others words, in the thick mist of life's beginnings. . . We have to try to discover the factors in the age-long process, and this leads us into a region where at present uncertainties abound" (Heredity, p. 12).

Professor Weismann says: "I do not mean to say that everything is clear in regard to the evolution of the living world. I believe that we stand still merely on the threshold of investigation, and that our insight into the mighty process of evolution, which has brought about the endless diversity of life upon our earth, is still very incomplete in relation to what may yet be found out" (The Evolutionary Theory, Vol. i., p. 6).

He says further: "We must always remain conscious that we cannot decide as to the possibility or impossibility of any biological process whatever from a purely theoretical standpoint, because we can only guess at, not discern, the fundameutal nature of biological processes" (Vol. ii., p. 64).

Sir Oliver Lodge said: "The universe we are living in is an extraordinary one, and our investigation of it has only just begun" (Contemporary Revieze, May, 1908).

Messrs. Dewar and Finn say : "What is the cause of germinal variations? This is a question to which we are not yet in a position to give a satisfactory answer. The attempt to explain their origin plunges us into the realm of theory. This, doubtless, is a 
realin full of fascination, but it is an unexplored region of extreme darkness, in which we believe it is scarcely possible to take the right road until more of the light of fact has been shed upon it" (The Making of Species, p. 110).

Mr. McCabe says: "Darwin's theory of pangenesis that tiny particles or gemmules are gathered into the germ from every cell in the body, each in time to reconstruct its parent cell-cannot now be entertained. . . . In my opinion we have not as yet an elementary clue to the way in which this microscopic germ builds up the body.

Those who postulate a 'vital force' in the germ either mean that an unconscious power is capable of doing what the highest human intelligence cannot do, or are saying in other words, with the rest of us, 'We do not know.'

"It is these very obscure phenomena to which the new theories of heredity are applied, and many will sympathise with the remark of Jordan and Kellogg that they are 'all guesses,' and that 'none of them is likely to be correct.' We must, however, distinguish an element of fact, and an element of guess in each: more precisely, an element that it ought to be possible to control by facts, and an element of pure speculation" (The Principles of Evolution, pp. 96, 97).

Professor W. Bateson, in his essav in Darwin and Modern Science, says, as regards the nature of sex: "It is not a little remarkable that on this point ... there should be diametrical opposition between the results of breeding experiments and those derived from cytology (the study of cells, or living units of protoplasm)" (p. 93).

Again, on the same subject: "How this contradictory evidence is to be reconciled we do not yet know" (p. 94).

On other points he has to make admissions: "In 
the light of present knowledge it is evident that before we can attack the species problem with any hope of success there are vast arrears to be made up" (p. 94).

"It will be realised that medleys of most dissimilar occurrences are all confused together under the term variation" (p. 95).

"With fuller knowledge we pass once more into a period of cautious expectation and reserve" (p. 96).

"There is nothing to be gained by disguising the fact that the attributes of living things are $110 t$ what we used to suppose" (p. 96).

"Not till knowledge of the genctic properties of organisms has attained to far greater completeness can evolutionary speculations have more than a suggestive value" (p. 96).

"As was said above, the time is not ripe for the discussion of the origin of species. With faith in Evolution unshaken-if indeed the word faith can be used in application to that which is certainwe look on the manner and causation of adapted differentiation as still wholly mysterious" (p. 99).

And his essay closes with words which we have already quoted: "No one can survey the work of recent years without perceiving that evolutionary orthodoxy developed too fast, and that a great deal lias got to come down'" (p. 101).

\section{Difficulties as to Natural Selection.}

'THERE are not a few biologists who, while believing in the principle of evolution, and holding that existing species have arisen through the modification of older and simpler forms, yet contend that there are many such changes which cannot have been due to Natural Selection.

Professor R. H. Lock, speaking of the family of the flat fishes, including the sole and the plaice, 


\section{R. H. LOCK ; LORD AVEBURY. 205}

says: "In the adult condition these fishes lie flat on one side, and during their development from the young condition, that eye which, if it remained in the original position, would look directly downwards, travels round the head until it comes to lie quite upon the upper surface. . . . It is impossible to explain the origin of this remarkable feature by the action of natural selection" (Recent Progress in the Study of Variation, Heredits', and Evolution, p. 35).

As regards the cat, he says: "The hind legs of such an animal as a cat are admirably adapted for the purpose of making a spring. In order to arrive at such a structure by the modification of limbs previously adapted only for rumning, changes must occur in almost all the bones, muscles, and ligaments of the limbs, and these changes must keep pace with one another, so that one part may not grow out of proportion with the rest. It is quite impossible to suppose that this can be effected by the natural selection of minute fortuitous variations of the various parts, each occurring, independently. But simultaneously with these changes the fore legs have become modified in a totally onposite direction" (p. 64).

Lord Avebury said: "The metamorphoses of insects have always seemed to me one of the greatest difficulties of the Darwinian theory" (quoted by H. Reinheimer in Nutrition and Evolution).

Messrs. D. Dewar and F. Finn, in The Making of Species, say that it is impossible to account for the origin of such a form as the Kallima butterfly, which displays a remarkable resemblance to a decaying leaf, by the action of natural selection (p. 45). They say further that natural selection fails to account for the origin of what is known as protective mimicry, it fails to explain the colours of the eggs 
of birds laid in open nests, why, for example, the eggs of the hedge sparrow are blue, and those of the dove white. Then it fails to explain the phenomena of sexual dimorphism: why, in some species of doves and ducks the sexes are alike, while in other species with similar habits they differ. It also fails to explain why the rook is black, and why the jackdaw has a grey neck (p. 51).

Professor Kellogg says: "Horses have small horny callosities on their feet. No one has suggested any possible use for them, but, nevertheless, they are present on the feet of all the species of the horse family. But the most curious fact is that while the horse has them on all four feet, the ass has them only on two. Now, upon the principle that utility is universal, it would be necessary to claim, not only that the presence of four callosities has been a matter of selective value in the horse, an extremely difficult thing to believe, but also that the presence of only two instead of four has been of selective value in the ass. This position approaches absurdity" (Darwinism To-day. p. 42).

He says further: "It is hardly possible for one, unless he has previously decided to accept the allsufficiency of natural selection, to believe that there can be any utility in the rery slight differences in the shape of leaves of plants, in the microscopic markings of the hairs of different species of mammals, the exact numbers of the feathers in the tails of birds, the peculiar distribution of the veins in the wings of a butterfly, the microscopic markings in the scales on its wings, or a host of other similar trivial characters. When it is remembered that the selection principle would force us to insist that all these characters are of value sufficient to protect their possessors at the expense of other individuals not possessing them, it is evident that the burden 
thrown upon the principle of survival becomes very great"' (p. 43).

Gustav Wolff, in Der gegenwärtige Stand des Daminismus, says that "while the theory of natural selection may get on decently well when modifications embodying only quantitative changes in parts or organs are concerned, it is completely at a loss to account for modifications or adaptations requiring as basis qualitative changes. Even the warmest advocates of the selection theory have to admit that they face a serious matter here" (quoted by Kellogg, p. 70).

De Vries, in The Mutation Theory, denies the species-forming capacity of the Darwinian variations on the ground that they are only "linear," and thus cannot afford a basis for the creation of new forms. Already existing bodies, organs, and parts can be enlarged or made smaller, made smoother or rougher, made bluer or less bine, greener or less green, that is, developed plus-ward or minus-ward, but by this nothing really new is created (Vol. i., p. 118).

Yves Delage, in L'Hérédité, says that "selection is powerless to form species. Its rôle, however, is not nul, but it is limited to the suppression of variations radically bad, and to the maintaining of the species in its normal character. Far from being an instrument for the evolution of species, it guarantees their fixity" (quoted by Kellogg, p. 93).

Professor T. H. Morgan says, in Evolution and Adaptation: "Our experience seems to teach us that selection of fluctuating variations leads us to only a certain point, and then stops in this direction. We get no facts in favour of the view that the process, if carried on for a long time, could ever produce such great changes, or the kind of changes as those seen in wild animals and plants" (p. 104). 
Weismann says : "It has lately been the fashion, at least among the younger school of biologists, to attach small value to natural selection, if not, indeed, to regard it as a superseded formula."

"What is meant by selection?" says Dr. H. Reinheimer, in his Nutrition and-Evolution. "As at present employed it is a vague, compound term, full of uncertainties"' (p. 145).

\section{Herbert Spencer's Views.}

HERIERT SPENCER published an essay On the lnadequacy of Natural Selection, in the Contemporary Revicit, in 1893, which was afterwards issued separately. He gives several illustrations to show that there are many things which natural selection cannot account for satisfactorily-the tactual perception of the tip of the tongue, in comparison with the tip of the forefinger; the keenness of scent in deer; the decrease in size of some organs (which he calls reversed selection); the smaller or larger jaw in some animals; the rudimentary eyes hidden tinder the skin of blind fish and amphibia; the eye of the protens, a blind animal found in caves in Carniola and Carinthia, etc.

Then he speaks of the immensely developed horns of some species, those, for instance, of the extinct Irish elk, weighing over a hundredweight. These " could not, with the massive ski1l bearing them, be carried at the extremity of the outstretched neck without many and great modifications of adjacent bones and muscles of the neck and thorax; and withont strengthening of the forelegs, too, there would be a failure alike in fighting and in locomotion." He continues: "While we cannot assume spontaneous increase of all these parts proportionate to the additional strains, we cannot suppose them to increase by variations, one at once, without 
supposing the creature to be disadvantaged by the weight and nutrition of parts that were for the time useless-parts, moreover, which would revert to their original sizes before the other needful variations occurred" (p. 20).

Mr. Spencer did not, however, look upon these difficulties as fatal to Darwin's theory ; he only cane to the conclusion that "in animals of complex structure, inheritance of acquired characters becane an important, if not the chief cause of evolution."

Upon this R. H. Lock says: "Unfortunately, satisfactory evidence that such a form of inheritance ever actually takes place has never been forthcoming in sufficient amount to lead to universal conviction. Indeed, at the present day, the consensus of opinion among experts is undoubtedly to the effect that acquired characters are not inherited at all, except in so far as better nutrition of the parent may lead to the production of more vigorous of spring. It seems that such an effect as the latter cannot go on accumulating for more than a few generations" (Recent Progress in the Study of Variation, etc., p. 115).

Professor Weismann's germ plasm theory is, of course, entirely antagonistic to the doctrine of the inheritance of acquired characters, and his arguments throughout the two volumes of his Evolutionary Theory are directed strongly against any such inheritance.

Herbert Spencer said: "Close contemplation of the facts impresses me more strongly than ever with the two alternatives-either there has been inheritance of acquired characters, or there has been no evolution" (Inad. Nat. Sel., p. 30).

Messrs. Dewar and Finn say : "Much of the popularity of the theory of natural selection is due to the fact that biologists have not yet been able to discover a substitute for it. It seems to us that the 
proper method of making progress in science is not to bolster up natural selection by ingenious speculations, but to look round for other hitherto undiscovered causes" (The Making of Species, p. 232).

Kellogg says: "The fair truth is that the Darwinian selection theories, considered with regard to their claimed capacity to be an independently sufficient mechanical explanation of descent, stand today seriously discredited in the biological world. On the other hand, it is also fair truth to say that no replacing hypothesis or theory of species-forming has been offered by the opponents of selection which has met with any general or even considerable acceptance by naturalists. Mutations seem to be too few and far between: for orthogenesis we can discover no satisfactory mechanism; and the same is true for the Lamarckian theories of modification by the cumulation, through inheritance, of acquired or ontogenic characters. Kurz und gut, we are immensely unsettled" (Darwinism To-day. p. 5).

\section{Darwin Admits Difficulties.}

In the Origin of Species Darwin himself makes many admissions as to the difficulties involved in his theory. No doubt he endeavours to meet these difficulties, and, that his explanations may be considered by any student, reference is made here to the page in the popular shilling edition of his book.

Chapter vi.: "Why, if species have descended from other species by fine gradations, do we not everywhere sce innumerable transitional forms?" (p. 124).

"Can we believe that natural selection could produce, on the one hand, an organ of trifling importance, such as the tail of a giraffe, and, on the other hand, an organ so wonderful as the eyc?"' (p. 124). 
"What shall we say to the instinct which leads the bee to make cells, and which has practically anticipated the discoveries of profound mathematicians?" (p. 124).

"How can we account for species, when crossed (i.e., different species breeding together), being sterile and producing sterile offspring, whereas, when varieties are crossed, their fertility is unimpaired ?" (p. 125).

"How could a land carnivorous animal have been converted into one with aquatic habits; for how could the animal in its transitional state have existed ?" (p. 129).

The human eye is discussed in pages 134 to 136 .

"The electric organs of fishes offer another case of special difficulty, for it is impossible to conceive by what steps these wondrous organs have been produced" (p. 140).

"The eyes of cephalopods or cuttle-fish and of vertebrate animals appear wonderfully alike; and in such widely sundered groups no part of this inheritance can be due to inheritance from a common progenitor" (p. 142).

Chapter vii.: "The celebrated palæontologist Bronn . . asks how, on the principle of natural selection, can a variety live side by side with the parent species" (p. 158).

"Bronn also insists that distinct species never differ from each other in single characters, but in many parts; and he asks, how it always comes that many parts of the organisation should have been modified at the same time through variation and natural selection?" (p. 158).

"A much more serious objection has been urged by Bronn and recently by Broca, namely, that many characters appear to be of no service whatever to their possessors, and therefore cannot have been in- 
fluenced through natural selection." Bronn adauces the length of the ears and tails in the different species of hares and rabbits, etc. (p. 159).

Chapter viii.: "Many instincts are so wonderful that their development will probably appear to the reader a difficulty sufficient to overthrow my whole theory" (p. 191).

(Ants, bees, dogs, cats, the cuckoo, etc., are discussed.)

"I will confine myself to one special difficulty which at first appeared to me insuperable, and actually fatal to the whole theory. I allude to the neuters or sterile females in insect communities; for these neuters often differ widely in instinct and in structure from both the males and fertile females, and yet, from being stcrile, they cannot propagate their kind"' (p. 214).

"We have not yet touched on the acme of the difficulty-namely, the fact that the neuters of several ants differ, not only from the fertile females and males, but from each other, sometimes to an almost incredible degree, and are thus divided into two or even three castes" (p. 215).

Chanter x.: "There is another... difficulty which is much more serious. I allude to the manner in which species belonging to several of the main divisions of the animal kingdom suddenly appear in the lowest known fossiliferous rocks" (p. 268).

"To the question why we do not find rich fossiliferous deposits belonging to these assumed earliest periods prior to the Cambrian system, I can give no satisfactory answer' (p. 269).

"The difficulty of assigning any good reason for the absence of vast piles of strata rich in fossils beneath the Cambrian system is very great" (p. 269).

Chapter xii.: "I am far from supposing that all 
the difficulties in regard to the distribution and affinities of the identical and allied species which now live so widely separated in the north and south, and sometimes on the intermediate mountain ranges, are removed on the views above given" (p. 320).

Chapter xiii.: "I do not deny that there are many and serious difficulties in understanding how many of the inhabitants of the more remote islands . . have reached their present homes" (p. 331).

Chapter xiv.: "There remains, however, this difficulty. After an organ has ceased being used, and has become in consequence much reduced, how can it be still further reduced in size until the merest vestige is left; and how can it be finall: quite obliterated? . . Some additional informa tion is here requisite which I cannot give" (p. 377).

\section{The Germ Plasm Theory.}

We may now look at some other theories which may be said to be in competition with Darwin's theory of Natural Selection.

Mr. J. A. S. Watson, in one of The People's Books, says: "The theory of heredity which is most widely accepted at the present time, and which is, in fact, the only theory that is of much sorvice in helping us to understand the facts, is the theory of the continuity of the germ plasm. The development of this main idea has been the great work of the German biologist, Weismann. In Weismann's own words, the idea is that part of the germ plasm 'contained in the parent egg-cell is not used up in the construction of the body of the offspring, but is reserved unchanged for the formation of the germ-cells of the following generation'" (Heredity, p. 15).

This theory is applied to all animals and plants. Professor J. Arthur Thomson thus illustrates this 
theory: "May we think for a moment of a baker who has a very precious kind of leaven; he uses much of this in baking a large loaf; but he so arranges matters by a clever contrivance that part of the original leaven is always carried on unaltered, carefully preserved for the next baking. Nature is the baker, the loaf is a body, the leaven is the germplasm, and each baking is a generation" (Heredity, p. 44).

But Professor Thomson says: "The conception of a germ-plasm is hypothetical, just as the conception of a specific living stuff or protoplasm is hypothetical. In the complex microcosm of the cell we cannot point to any one stuff and say, "This is protoplasm'; it may well be that vital activity depends upon several complex stuffs which, like the members of a carefully constituted firm, are characteristically powerful only in their inter-relations. In the same way it must be clearly understood that we cannot demonstrate the germ-plasm" (Heredity, p. 44).

Professor Weismann, in the two volumes of The Evolutionary Theory which explain his system, makes some admissions which should be noted. He says: "It is true that we cannot learn anything directly in regard to the intimate structure of the germ-plasm, and even in regard to the vital processes going on within it we can only guess a very. little, but so much we may say-that its living parts are nourished, and that they multiply" (Vol. ii., p. 116).

Again: "No one who is unwilling to accept germinal selection can be compelled to do so. . . . It is not built up from beneath upon axioms, but is an attempt at an explanation of a fact established by observation - the disappearance of disused parts. But when once the inheritance of functional modifications has been demonstrated to be a fallacy, and 
when it has been shown that, even with the assumption of such inheritance, the disappearance of parts which are only passively useful, and of any parts whatever in sterile animal forms, remains unexplained, he who rejects germinal selection must renounce all attempt at explanation" (Vol. ii. p. 121). Again: "We cannot reach clearness on this point through our present knowledge of the germplasm, because we possess no insight into its structure: we can only draw conclusions as to the processes in the germ-plasm from the observed phenomena of variation and inheritance" (Vol. ii., p. 127).

At length he says: "As yet the material for such inductions is scanty, because it has been yot together haphazard, and not collected on a definite plan. I therefore refrain for the present from attempting any further elaboration of my germ-plasm theory" (Vol. ii., p. 190).

\section{The Mutation Theory.}

Hugo De VRies, Professor of Botany at Amsterdam, brought out a work at Leipsic in 1903 which was translated and published in London in 1911 under the nane of The Mutation Theory.

He defines the principle of his theory thus: "The current belief assumes that species are slowly changed into new types. In contradiction to this conception, the theory of mutation assumes that new species and varieties are produced from existing forms by sudden leaps. The parent-type itself remains unchanged throughout this process, and may repeatedly give birth to new forms. These may arise simultaneously and in groups or separately at more or less widely distant periods" (Species and Varieties, 1905, preface).

In hunting about the suburbs of Amsterdam, De Vries came across a deserted potato field at Hil- 
versum. There he found a long looked-for mutable plant, an Evening Primrose. It had probably come from America, where it is a native, and had escaped from a park. In ten years it had spread in hundreds over the field. Professor J. Arthur Thomson says: "Its chief interest was its changefulness. It had, so to speak, frolicked in its freedom. Almost all its organs were varying-as if swayed by a restless tide of life. It showed minute fluctuations from generation to generation; it showed extraordinary freaks like fasciation and pitcher-forming; it showed hesitancy as to how long it meant to live, for while the majority were biennial, many were annual, and a few were triennial; it showed what can hardly be otherwise described than as new species in the making" (Heredity, p. 91).

Some writers have treated the Mutation theory of De Vries as an auxiliary to Darwin's theory of Natural Selection. De Vries himself shows that on the theory of Selection millions of years would be needed for the attainment of the present high degree or organisation of, for example, the eye, and he says that the extraordinarily long time which the Selection hypothesis demands leads us to suspect that there is some weak spot in the argument. (The Mutation Theory', Vol. ii., p. 664). But if changes in varions organs came by "leaps and bounds," this difficulty would be removed.

Then he says that while the theory of selection explains the existence of useful characters, it does not explain that of useless or actually harmful ones (p. 612). He says also that the first insignificant beginnings of new characters do not come under the operation of Natural Selection (p. 611). On these points he thinks that the Mutation theory is a key to the difficulty.

But it must be observed that the idea of pro- 
gress by leaps and bounds is entirely contrary to the general principle laid down by Darwin. He says: "Natural selection acts only by taking advantage of slight successive variations; she can never take a great and sudden leap, but must advance by short and sure, though slow steps." (Origin of Species, chap. vi.).

Again: "As natural selection acts solely by accumulating slight, successive, favourable variations, it can produce no great or sudden modifications; it acts only by short and slow steps. Hence the canon of Natura non facit saltum, which every fresh edition to our knowledge tends to confirm, is on this theory intelligible" (chap. xv.).

Darwin was surely, unrivalled as a student of nature, and this testimony of his seems flatly to contradict the Mutation idea.

Some confusion has arisen in the discussions on the subject, in consequence of the different way in which terms are used by different writers. Sone call mutations "discontinuous variations," or speak of "saltatory evolution or variation," while the variations referred to by Darwin are called indefinite or "fluctuating" variations.

Professor Weismann says: "There are many variations which have appeared in a sudden and saltatory manner, and some of these Darwin pointed out and discussed in detail: the copper beech, the weeping trees, the oak with fern-like leaves, certain garden-flowers, etc. But none of them have persisted in free nature, or evolved into permanent types. . . Even if saltatory variations do occur, we cannot assume that these have ever led to forms which are capable of survival under the conditions of wild life. Experience has shown that in plants which have suddenly varied the power of persistence is diminished.

"It now appears that the far-reaching conclu- 
sions drawn by De Vries from his observations on the Evening Primrose, Oenothera lamarckiana, rest upon a very insecure foundation. The plant from which De Vries saw numerous 'species'-his 'mutations' - arise, was not, as he assumed, a wild species that had been introduced to Europe from America, but was probably a hybrid form which was first discovered in the Jardin des Plantes in Paris, and which does not appear to exist anywhere in America as a wild species.

"This gives a severe shock to the "Mutation theory,' for the other actually wild species with which De Vries experimented showed no 'mutations' but yielded only negative results" (Damin and Modern Science, pp. 23, 24).

Professor 'Thomson, in his Heredity', inclines to favour the views of De Vries. He gives as illustrations of discontinuous variation the Wonder Horses (with a mane 18 feet long, and a tail 21 feet long), the Shirley Poppies, the Star Primrose, the Moth Amphidasys, the Common Jelly Fish, etc. (p. 87).

Farther on he says: "It is quite conceivable that a mode of evolution common among plants may be rare among animals. It is difficult at present to apply the nutation concept with security to the animal kingdom" (p. 98).

Messrs. Dewar and Finn, in The Making of Species, give some instances of great and sudden variations in domestic animals (not, it will be observed, of animals in the wild state)-the hornless Paraguay Cattle, a breed of long-horned cattle in Brazil, the Ancon sheep of Massachusetts, the Manchanup breed of Merino sheep, the tufted turkeys, the long-haired race of guinea-pigs, the black-winged peafowl, the Golden Pheasant, etc. (pp. 95-97). But they mention also one or two cases of wild animals.

They say, however, that De Vries "suffers from 
the complaint that seizes nine out of ten originators of new theories. He pushes his theory to extreme lengths; he allows his imagination to run away with him." They add: "He is justified in asserting that discontinuous variation is by no means an uncommon phenomenon, but further than this it does not seem safe to go at present"' (p. 87).

In an article on The Present Position of Darwinism in the Contemporary Review of August, 1908 , Dr. Wallace said: "There is no proof whatever that in a state of nature such mutations are produced, except, perhaps, very rarely; while the assumption that they have been and are produced so frequently as to constitute the mode by which all existing species have come into existence is a most illogical conclusion to draw from the phenomena presented by one species of plant of totally unknown parentage!"

Then, referring to the advocacy of the mutation theory by Professor A. A. W. Hubrecht in an article in the Popular Science Monthly, Dr. Wallace adds: "These positive assertions as to what has occurred throughout the whole realm of organic nature in the whole course of its development rest wholly on experiments with one plant, although those experiments are rendered comparatively valueless owing to its not being itself a known wild species, but probably a hybrid. Was there ever such a mountain of theory reared upon such an almost infinitesimal basis of fact!'

\section{Orthogenesis.}

THE study of palæontology has shown to naturalists that variation has not in the past been wholly fortuitous, miscellaneous, indeterminate, as Darwin's theory supposes. The changes in organisms have by no means been always to their advantage, leading them to evolve into other forms higher in 
the scale of nature. In many cases there has been ultra-development of parts which has even led to death and extinction. Kellogg instances the unwieldiness of the great Cretaceous reptiles, the fixed habit of life of the crinoids, the coiling of the ammonites and nautili, and the gigantic antlers of the Irish stag as examples of development along disadvantageous lines.

Then he shows that there are numcrous cases in which there has been a tendency in the variations of insects and plants, especially to occur along certain lines, and to accumulate in certain directions. 'This tendency is explained by some writers by a theory which is called Orthogenesis, and which, according to Professor Eimer, is in a certain sense opposed to Darwin's theory, "since it recognises a perfectly definite direction in the evolution and contimuous modification of organisms" (Organic Evolution, p. 431).

Professor Nägeli advocates a theory of Orthogenesis, which finds (according to Kellogg), in a somewhat mystical vitalistic inner force, "a something inherent in the organic world which makes cach organism in itself a force or factor making towards specialisation, adaptation, that is, towards progressive evolution." Other authors, he says, who accept such a theory of an inherent driving force in organisms, speak of this factor variously as an "inner directive force," an "inner law of development," or an " intrinsic tendency towards progress" (Darwinism To-day, p. 278).

Professor Eimer, in his Organic Evolution, takes a different standpoint. His views are derived largely from his studies of wall-lizards, caterpillars, butterfiies, bees, wasps, birds, etc. He advocates a theory of the evolution of species through Orthogenesis, guided by external influences-climate, 
light, warmth, moisture, and differences of food (p. 153)-but also depending on the material composition of the body (p. 21), but, he says, "always in definite directions, and indeed in each species in a given time only in a few directions" (p. 20). He repudiates any special internal force of evolution ( $p$. 64).

He compares his view of Orthogenesis with the growth of the individual: "The evolution of the organic world ever into higher and more complex forms, or at least into forms of different structure, is, as I have said, merely the sum of the processes of growth of the ancestors-together with the result of external influences on the forms during their development and their existence" (p. 382).

Professor E. D. Cope in The Origin of the Fittest, advocated a theory of what he called growth-force, or Bathmism, as the chief cause of evolution, and he has been followed by Professors Osborn and Hyatt and other American naturalists. Dr. Wallace says: "This school endeavours to explain all the chief modifications of form in the animal kingdom by fundamental laws of growth and the inherited effects of use and effort, returning, in fact, to the teachings of Lamarck as being at least equally important with those of Darwin." He calls these - ideas "theoretical conceptions which have not yet been tested by experiments or facts, as well as metaphysical conceptions which are incapable of proof" (Darwinism, pp. 420, 422).

Professor Bateson, in Darwin and Modern Science, says of Eimer's theory of Orthogenesis, that "no fragment of real evidence can be produced in its simport" (p. 101).

The article Evolution in the Encyclopedia Britannica says that many writers have been led to the conception that there is something of the 
nature of a growth-force inherent in organisms, and tending inevitably towards divergent evolution. "The conception is necessarily somewhat hazy, but the words bathmism and bathmic evolution have been employed. . . Until the more obvious lines of enquiry have been opened out much more fully, we cannot be in a position to guess at the existence of a residuum, for which such a metaphysical conception as bathmism would serve even as a convenient disguise for ignorance."

\section{Vitalism.}

A THEORY of evolution that supposes an inner directive force or impulse in organisms is that expounded by Professor Hans Driesch in his Aberdeen Gifford Lectures: it is known as Vitalism, but the term is often used in a more general way.

Messrs. Thomson and Geddes in Evolution, express sympathy with the doctrine of Vitalism, but they confess that "as yet no vitalist writer has succeeded in making himself and his nomenclature really intelligible to any other" (p. 202).

Mr. McCabe says: "The one argument for this orthogenetic theory of evolution is that the opposing theory has many difficulties, but there is little profit in exchanging one set of difficulties for another." And he adds: "The theory of directed evolution seems inconsistent with the facts, and introduces more mysteries than it solves" (The Principles of Evolution, p. 247).

\section{Mendelism.}

Gregor Mendel, Abbott of Brünn, in Silesia, made experiments in his garden with common peas, and published the results in 1865 , but it was not until 1900, eighteen years after his death, that the attention of the scientific world was drawn to his 
work by De Vries and other botanists, and Professor Bateson, who has written Mendel's Principles of Heredity (1902), and who was President of the British Association meetings in Melbourne and Sydney, in August, 1914, is a prominent champion of Mendelism.

Mendel crossed several varieties of peas, and, from careful observation of the hybrid plants, made the discovery that the variations in the offspring obeyed certain definite laws. Many other naturalists have in recent years experimented with beans, sweet peas, stocks, maize, wheat, barley, fruits of various kinds, fowls, rabbits, mice, etc., and have thus established the general truth of the principles of Mendelian inheritance, although, so far, these have not proved to be of universal application.

In simple experiments, when only two characters, like tallness and dwarfness in peas, are compared, or two colours in flowers, one is found to be the dominant character, and then the other is called the recessive. Then in the offspring, and in succeeding generations, the dominants and recessives occur in fixed proportions.

This discovery of the facts of Mendelian inheritance might seem to have upset what has been known as Mr. Galton's Law of Ancestral Inheritance, which runs: "The two parents contribute between them on the average one-half of the total heritage of the offspring: the four grandparents one-quarter, the eight great-grandparents one-eighth, and so on," but Dr. J. A. Thomson says that while, when dealing with Mendelian unit characters, Galton's law is not relevant, yet as regards other characters, such as the fluctuations of stature in mankind, Galton's law is a valuable statistical description (Heredity, $p$. 331 ).

Segregation is claimed as the principle which ex- 
plains Mendelian inheritance. Professor Bateson says, in Dariulin and Modern Science: "Segregation, a phenomenon of the utmost novelty, was thus revealed. From that moment not only in the problem of the origin of species, but in all the great problems of biology a new era began. . . The essential deduction from the discovery of segregation was that the characters of living things are dependient on the presence of definite elements or factors, which are treated as units in the processes of Heredity. These factors can thus be recombined in various ways. They act sometimes separately, and sometimes they interact in conjunction with each other, producing their various effects. All this indicates a definiteness and specific order in heredity, and therefore in variation" (p.92).

Mr. E. S. Goodrich says: "This whole systen of factors may appear to the reader somewhat artificial; yet it is the legitimate deduction from facts for which no other explanation can at present be given. What the factors are we can only surmise" (Evolution, p. 48).

Professor T. H. Morgan says, in the conclusion of his recent book, The Theory of Evolution: "The evidence shows clearly that the characters of wild animals and plants, as well as those of domesticated races, are inherited both in the wild and in the domesticated forms according to Mendel's Law."

It is supposed that, as the knowledge of Mendelian principles becomes more widely disseminated, it will lead to important results through improved methods in the breeding of animals and the cultivation of plants. Mr. R. H. Biffen clains to have demonstrated by his experinents what may be done in establishing more profitable varieties of wheat and barley. 
We read much in biological works of "chance" variations in Nature, but Mendel's discovery seems to prove that much more than was supposed is governed by natural laws.

For fuller particulars the student should consult Mendelism by Mr. R. C. Punnett, but there is a small sixpenny book:-Heredity, by Mr. J. A. S. Watson, which will give much information.

In his article in the Contemporary Review already referred to, Dr. Wallace strongly criticised some of the Mendelian experiments, and he gave extracts from The Origin of Species to show that the fundamental fact of Mendelism-that certain characters in a few special cases do not blendwas well known to Darwin, Lut that he was satisfed that hybridisation, or the intercrossing of very distinct forms, had no place whatever in the natural process of species-formation.

In The World of Life, Dr. Wallace speaks of the modern theories of MIutation and Mendelism as "hopelessly inefficient" and "ludicrously inadequate," and he says: "The phenomena lpow which these theories are founded seem to me to be mere insignificant by-products of heredity, and to be essentially rather self-destructive than preservative. They form one of nature's methods of getting rid of abnormal and injurious varjations" (p. 123).

In a recent volume (1917) on The Theory of Evolution, Professor W. B. Scott, of Princeton University, U.S.A., says: "Interesting and profoundly important as are the results of the Mendelian investigations . . they have rendered but little assistance in making the evolutionary processes more intelligible, and, instead of removing difficulties, they have rather increased them" (p. 163). 


\section{Creative Evolution.}

IVE cannot pass by the riews of Professor Henri Bergson, which are found in his remarkable book, Creative Evolution. It is a work of very great originality, and opens up many deeply interesting questions, not only as to the world in which we live, but as to the universe at large.

Messrs. Thomson and Geddes speak of his evolu. tionary theory as a theory of Vitalism. His great idea is that of an "original impetus of life," and he says that "life is, more than anything else, a tendency to act on inert matter" (p. 102). He says, "It must be compared to an impetus, because no image borrowed from the physical world can give more nearly the idea of it" (p. 271).

M. Bergson is fertile in illustrations. His main conception seems to be that of a volume of life sent out, like a stream of water, with an original impetus, and taking its course in different currents according to the ground it has to traverse. He speaks of an immense reservoir of life (p. 261), of a current of life (p. 280), of a great wave of life starting from a centre and spreading outwards $(p .280)$, and he says that life "is the continuation of one and the same impetus, divided into divergent lines of evolution " (p. 56). He looks upon humanity as a stream that has gone further than all the other streams, and yet he says that man's brain differs from other brains in this, that the number of mechanisms it can set up is unlimited. "Now, from the limited to the unlimited there is all the distance between the closed and the open. It is not a difference of degree, but of kind" (p. 278). The testimony given in this last sentence is of the utmost importance for the purpose of the argument against human evolution.

One is apt to be carried away with M. Bergson's vivid and captivating illustrations, so that there is a 
danger of forgetting that he does not substantiate them by any body of facts, though he does indeed adduce some facts in criticism of the Darwinian position. Messrs. Thomson and Geddes say : "Even in Bergson, much more in the German vitalists, there is too much of the intangible" (Evolution, p. 209).

Mr. McCabe quite opposes M. Bergson's theory, and especially in regard to the chapter on Instinct he says: "His whole conception of instinct is fantastic and baseless" (The Principles of Evolution, p. 251).

\section{Multiple-Character Evolution.}

ONE of the latest evolutionary theories, if we may call it such, is found in a recent paper by Professor H. F. Osborn, in Nature, on The Origin of New Adaptive Characters. Professor Osborn has been for about fifteen years studying the "titanothere" family, fossil rhinoceros-like mammals of the Oligocene and Eocene strata of North America, and he says: "The most significant result derived from the intensive study of the evolution of this family is the law of multiple-character evolution, namely, that evolution progresses in every one of the single characters of which an organism is composed. Each character possesses its own individuality and separableness, each advances or lags behind according to its individual velocity, each subserves the general purpose of the entire organism through the uniting forces which we term correlation.

"In 1889 I held that the reaction-inheritance of I amarck was the only explanation we have for such directive or orthogenetic tendencies in evolution as are displayed especially in the origin of characters which I have termed "rectigradations." I subsequently-with Baldwin and Iloyd Morgan-discovered the organic selection principle. 
"All that we can positively state at present is that the adaptive trend in the origin of new specific and generic characters is the resultant of the interactions of four sets of forces: germinal, enviroumental, ontogenctic, and selective, as expressed in the law of 'tetraplasy.'. .

"In certain cases one or other of these four complexes of forces may be dominant, so that the visible changes which we observe in animals may for a time be chicfly either ontogenetic, or environmental, or germinal, or selective" (Nature, Nov. 11 th, 1915, p. 284).

\section{Systematic and Natural Species.}

UNDER this title the Rev. Erich Wasmann, of Luxemburg, in his Modern Biology and the Theory of Evolution, published in English in 1910, advocates a theory that a certain number of species of animals and plants were created in the beginning, and that other species have been derived from these by a process of cvolution, and he says that this "supplies us with a firm philosophical basis, upon which the theories of creation and descent can easily be reconciled with one another" (p. 299).

He thinks we may reckon, as belonging to one matural species, all the varieties of beetle of the Paussidce family (p. 297) ; all the numerous genera and species of ants from the earliest Jurassic period to the present day; also the fanily of termites, writh its great variety of fossil and still existent genera and species (p. 298). Then he instances as probably one natural species all the present varietfes of horse and their fossil ancestors ; and, among molluses, he mentions the Ammonites as a group of forms very rich in systematic families, genera, and species, which can be traced from the Devonian to the Cretaceous period, as all belonging to one natural species (p. 299). 
He adds: "If we call each of the hypothetical and distinct lines of evolution in the organic world a 'natural species,' we may say : 'There are as many natural species as there were originally different primitive forms produced at the creation of the organic world. We must leave it to future biologists to determine the number and extent of these natural species, and the structure of their primitive forms" (p. 303).

\section{Spontaneous Generation.}

WF: will now consider briefly several subjects that are often discussed in books on Evolution, and that have an important bearing on the theory.

The Presidential Address of Professor E. A. Schäfer at the meeting of the British Association at Dundee in 1912 brought prominently before the public mind the question of the Origin of Life.

In that address he developed his entirely materialistic theories. "Setting aside," he said, "as devoid of scientific foundation, the idea of immediate supernatural intervention in the first production of life, we are not only justified in believing, but compelled to believe, that living matter must have owed its origin to causes similar in character to those which have been instrumental in producing all other forms of matter in the universe; in other words, to a process of gradual evolution." 'This, of course, involved the theory of spontaneous generation, or abiogenesis, which derives all vegetable and animal life from the inorganic world-the world of rocks, minerals, etc.

Two centuries ago it was generally believed that much animal life had been bred in putrefied matter, and the origin of flies, bacteria, and other low organisms was thus explained. The discovery of the microscope, as it made known the existence of more minute forms of life, at first secmed to increase the possibilities of spontaneous generation, until 
the researches of Pasteur, Tyndall, and others definitely proved that such organisms arise from germs and spores present in certain liquids, and, as Goodrich says, that "neither putrefaction nor fermentation will take place, nor organisms of any kind appear, in substances which have been thoroughly sterilised." (Evolution, p. 17).

And Lord Kelvin said: "I am ready to accept as an article of faith in science, valid for all time and in all space, that life is produced by life, and only by life."

Huxley said, in closing his essay on The Origination of Living Beings: "With the particulars of M. Pasteur's experiments before us, we cannot fail to arrive at his conclusions; and that the doctrine of Spontaneous Generation has received a final coup de grâce."

Professor P. C. Mitchell, in the article Abiogenesis in the Encyclopadia Britannica, says: "It may now be stated definitely that all known living organisms arise only from pre-existing living organisms;" and in the article Biogenesis, in the same work, he says: "No biological generalization rests on a wider series of observations, or has been subjected to a more critical scrutiny, than that every living organism has come into existence from a living portion or portions of a pre-existing organism." This is the important principle of nature expressed in the phrase, Omne vivum e vivo.

M. Bergson, in Creative Evolution, refers to a book by the histologist, E. B. Wilson, The Cell in Development and Inheritance, who comes to this conclusion: "The study of the cell has, on the whole, seemed to widen rather than to narrow the enormous gap that separates even the lowest forms of life from the inorganic world" (p. 38). (Histology is the science which deals with the structure of the tissues of plants and animals.) 
Notwithstanding this, there are some of the foremost advocates of Evolution who hold that, at some time or other in the world's history, the spontancous generation of life from inorganic matter must have taken place.

Professor C. Guenther, in Darwin and the Problems of Life, says: "No element has been found in living matter that is not also found in inorganic inatter. There is no essential difference between the albuminoids and other compounds.... We are thus driven by a number of considerations to the conclusion that life was born on our planet. It is no objection to our theory that we have not yet succeeded in artificially producing living matter or animals. How can we do this when we do not know the structure of living albumen nor the forces that create it? The fact that no matter has yet been produced artificially only shows that a certain experiment has failed"' (p. 315).

Further on he says: "Thus we are forced to ascribe psychic phenomena even to inorganic matter. Why they are not recognisable in it, or why they are so different even in the lowest animals, it is impossible for us to say" (p. 404).

Weismann, in The Evolutionary Theory, says: "It would be impossible to prove by experiment that spontaneous generation could never have taken place; because such negative experiment would only prove that life does not arise under the conditions of the experiment. But this by no means excludes the possibility that it might arise under other conditions. Up till now all attempts to discover these conditions have been futile, and I do not believe they will ever be successful" (Vol. ii., p. 366).

Further on he says: "We are driven back to the lowest known organisms, and the question now before us is, whether these smallest living organisms, 
which are only visible under the highest powers of the microscope, may be referred to spontaneous generation. But here the answer is 'No'; for although there is 110 nucleus to be found, and no substance which we can affirm with any certainty to be composed of primary constituents or idioplasm, we do find distinct traces of a previous history, and not the absolutely simple structure of homogencous living particles, unarranged in any orderly way, which is all that could be derived from spontaneous gencration"' (p. 368).

And yet he has to add: "I see no possibility of avoiding the assumption of spontaneous gencration. It is for me a logical necessity" (p. 366). That is to say, Professor Weismann admits that his general theory demands what he clearly shows is so incapable of proof.

We have just seen what Professor Guenther says as to all the elements of living matter being found in inorganic matter. But Weismann remarks: "While dead albumen is certainly nearly allied to living matter, it is preciscily life that it lacks" (p. 369).

There are other biologists who will not quite give up the idea that there may have been a time in the rorld's history when spontaneous generation may have been possible. Messrs. P. Geddes and J.A. Thomson, in Evolution in the Home University Library, say: "Though prolonged experiments have led biologists to adhere dogmatically to the dictum Omne vivum $c$ vivo, this is not inconsistent with supposing that spontaneous generation occurred in favourable conditions very long ago" ( $p$. 71).

Mr. E. S. Goodrich says, in his Evolution: "We must, however, suppose that at some period in the earth's history, when conditions were favourable, and perhaps very different from those of the present 

time, living protops..... made a first appearance"
(p. 17).

And Huxley said, in his Presidem.... nddress at the British Association in Liverpool, in 18ress at must carefully guard myself against the supposition that I intend to suggest that no such thing as abiogenesis ever has taken place in the past or ever will take place in the future. With organic chemistry, molecular physics, and physiology yet in their infancy, and every day making prodigious strides, I think it would be the height of presumption for any man to say that the conditions under which matter assumes the properties which we call 'vital' may not, some day, be artificially brought together."

The Cambridge Natural History says: "Of the nltimate origin of organic life from inorganic life we have not the faintest inkling. If it took place in the remote past, it has not been accomplished to the knowledge of man in the history of scientific experience, and does not scem likely to be fulfilled in the immediate or even in the proximate future" (Vol. i., p. 44).

In a footnote it says: "Dr. H. C. Bastian has recently maintained a contrary thesis (The Nature and Origin of Living Matter, 1905), but has produced no evidence likely to convince anyone familiar with the continuous life-study of the lower organisms."

Professor Mitchell, in the article Life in the Encyclopadia Britannica, says: "Theories of the origin of life apart from doctrines of special creation or of a primitive and slow spontaneous generation are mere fantastic speculations. . . . H. E. Richter appears to have been the first to propound the idea that life came to this planet as cosmic dust or in metcorites thrown off from stars and planets." But Messrs. Geddes and Thomson say: "It is difficult to conceive of anything like the protoplasin we 
know surviving transport in a mawrite" (p. 70). And surely we might astr, rsow did life originate in the star or masce from whence the meteorite camp? Wallace was a reply to Dr. Schäfer, which is to be found in the number of Everyman for October 18th, 1912. He concludes :-

"Finally, Dr. Schäfer assures us that, as supernatural intervention is unscientific, we are compelled to believe that living matter must have owed its origin to causes similar in character to those which have been instrumental in producing all other forms of matter in the universe; in other words, to a process of gradual evolution.

"I submit that, in view of the actual facts of growth and organisation as here briefly outlined, and that living protoplasm has never been chemically produced, the assertion that life is due to chemical and mechanical processes alone is quite unjustified. NEITHER THE PROBABILITY OF SUCH AN ORIGIN, NOR EVEN ITS POSSIBILITY, HAS BLEN SUPPORTED BY ANYTHING WHICH CAN BE TERMED SCIENTIFIC FACTS OR IOGICAI, REASONING."

From this summary we see that, while there is not the slightest scientific evidence in farour of Spontaneous Generation, the biologists who look upon Evolution as a principle ruling throughout Nature are compelled to suppose that at some time in the past history of the earth it must have occurred. Their theory demands it, therefore, as Weismann says, it is a "logical necessity." And it is these thorough-going Evolutionists who, from the same "logical necessity," include the human race in their scheme of evolution : their theory demands it, and therefore man must have been evolved!

Spontaneous generation is sometimes called 
Generatio achuivoca, and the theory that it occurred in remote ages of the world has been called Archebiosis, or Archegenesis.

\section{The Inheritance of Acquired Characters.}

A SUnJEC' of continual discussion between evolutionists is the question whether variations, modifications, or characteristics, acquired during the lifetime of an individual, these modifications being usually due to the use or disuse of special organs, can be transmitted by the individual to its offspring. Herbert Spencer attributed the smallness of his hands to the fact that his father and grandfather were schoolmasters, and that their hands were never developed by manual labour. Kellogg says : "Animals often chased by enemies become fleeter by practice; animals that must dig for roots, or climb trees for leaves and fruits, or dive for fishes, or leap over obstacles, come by repeated digging, climbing, diving, or leaping, to do these things better. . . . If such betterment of organs and their functions could be inherited by their young, it is obvious that general adaptations of this sort could be rapidly developed in the course of generations, and new species, new, that is, because of the adaptive changes thus effected, be formed" (Damwinism Today, p. 265).

This was the principle adopted in the theory of evolution advocated by Jean Lamarck, Professor of Zoology at Paris, who published his Philosophic Zoologique in 1809 , fifty years before Darwin. The doctrine of the inheritance of acquired characters is therefore often called Lamarchism. hold it in the present day are called NeoLamarckians.

Professor R. H. Lock says: "Lamarck supposed 
that snakes were evolved from a pre-existent type of animal which was of a much less attenuated shape, and which possessed two pairs of limbs like any other vertebrate. And he supposed this evolution to have taken place owing to the constant striving of these animals to pass through narrow crevices : the effect of such striving being inherited, and so accumulated from one generation to another" (Reccul Progress in the Study of Variation, Heredity, and Evolution, D. 16).

Dr. J. A. Thomson mentions other illustrations of Lamarck's theory: "The giraffe has attained its long neck by stretching it for many generations; swimming birds have got webbed feet because they stretched their toes in the water; wading birds have got long legs because they stretched them; the mole has very small eyes because it has ceased to use then ; the whalebone whale has no functional teeth because it has acquired the habit of swallowing its food without mastication; and so on" (Heredity. p. 170).

The Origin of Species contains many passages in which the Iranarckian position is taken. Kellogg says: "Darwin, while constantly trying to rely, and whenever possible relying on natural selection as the species-forming and adaptation-explaining cause, never hesitated, when it seemed necessary, to admit the infuncence and effect of the inheritance of acquired characters or the infuence of other, to him, unknown factors" (Darrinism To-day, p. 76).

The great opponent of Iamarckian views is Professor Veismann, because onc of the logical consequences of his theory of the "continuity of the germplasm" is, that acquired characters of whatever kind are not transmitted from parent to offspring.

Guenther says: "The Iamarckians say that 
certain mammals, such as whales and walruses, have almost entircly lost their heavy coat because of the constant action of the water. In other animals the water is said to have formed horny plates on the mucous lining of the palate, as in the tortoise, the duck-bill, and the whale. We may ask, then, why the water has not reduced the fur of the otter, the beaver, the seal, and the waterrat, and why we find no horny plates on the palate of the crocodile, the dolphin, and other aquatio animals. The external influence is the same in the case of each of these animals. Why is there different re-action in each?" (Narin and the Problems of Life, p. 342).

Dr. Wallace, in his Darwinism, is disposed to agree with Weismann, and he considers that many instances of change imputed to the inheritance of acquired variations are really cases of natural selection (p. 440).

The whole subject is treated very fully in Dr. J. A. Thomson's Heredity, and its discussion occupies a large part of his book.

It is generally agreed that mutilations, wounds, etc., are not transmitted to descendants; the dishorning of cattle, the docking of horses' tails, the cropping of dogs' ears, and similar practices have been continued for many generations without any known hereditary effect. The same may be said of the foot-binding of Chinese girls.

Professor Th. Eimer, in his Organic Evolution. entirely opposes Weismann's views on this subject. After giving many instances of the effect of climate and food on animals, he says: "Consider the limbs of Ungulata and other animals: the foot of the horse, of the ostrich, the hind-foot of the kangaroo, in their partly degenerate, partly specialised structure, depend only upon inherited acquirements due 
to adaptation to the same physiological demand, i.e., diminution of the number of the toes, and increase in strength of the one or few remaining for the sake of greater firmmess and more rapid progress on hard ground-in contrast, for example, with the five-toed foot of the clephant, which is adapted to prevent any sinking into the soil" (Organic Evolution, p. 165).

He asks why most dogs cary their tails erect, while wolves and jackals, from which they are descended, do not. He considers this an acquired and inheried character; the jaclial-dogs of the East, and our sheep-dogs, which are not far removed from the wolf, carry their tail depressed like the wolf and jackal (p. 171).

Haecliel has declared that "bclicf in the inheritance of acquired characters is a necessary axiom of the monistic creed" (Thomson's Heredity, P. 195).

Yet Dr. Thomson says: "Have we any concrete evidence to warrant us believing that definite modificatious are ever, as such or in any representative degree, transmitted? It appears to us that we have not. But to say dogmatically that such transmission is impossible is unscientilic" (Heredity, $\bar{n}$. 24\%:

Kellogg says: "This matter of the inheritance of acquired characters, apparently easily susceptible of definite proof or refutation by obscrvation and $c x-$ periment, has been for years and is to-day one of the burning problcms of biology. . . . Just at prescut the weight of evidence inclines strongly against such an inheritance, chiefly because of Weismann's successfully destructive criticism of about all the evidence of observation which has been offered in behalf of it. And yet just at the present time do biologists recognise more keenly than eved the need and the relief the actuality of such inherit- 
ance would give them in their efforts to solve the great problems of adaptation and species-forming" (Darininism To-day, p. 263).

\section{Isolation.}

ThE world-voyager and exploring naturalist Moritz Wagner, at a conference at Munich in 1898, advocated a theory, based on his observations during his travels, that evolution was due to the migration and consequent isolation of species, and he thought that this made the natural selection theory superfluous. Although very few naturalists followed him as far as that, there is no doubt that isolation has had considerable influence in the changes that bave occurred in many species.

Whatever the barrier which cuts off more or less completely a number of individuals from the main stock, the result is the same-they tend to diverge from the parent species. "Land organisms become geographically isolated by the formation of barriers such as deserts, or mountain ranges, or by the separation of islands from a mainland. Marine organisms may be divided by the uprising of dry land, and the inhabitants of fresh water by the separation of river basins." Mr. Goodrich says : "The marine and littoral fauna on the opposite coasts of the isthmus of Panama differ considerably, but differ far less than does the fauna of the Mediterranean from that of the Red Sea, these seas having been separated for a much longer time. In the Sandwich Islandis there are some 300 species of the genus Achatinella, almost every valley having its own peculiar form of this mollusc. . . . Islands afford excellent illustrations of divergence through isolation. . . F For instance, almost every one of the West Indian Islands has its representative species of the golden oriole. The Galapagos 
Archipelago has its own reptiles, insects, and land molluses; out of some thirty species of land birds, about twenty-eight are peculiar: while each one of these islands has developed its own race of the gigantic land tortoise" (Evolution, p. 71).

Dr. Wallace, however, in his Darwinism, points out that isolation by itself cannot be an efficient cause of change of species, because in Ircland, which has been scparated from Britain since the end of the Glacial epoch, hardly one of the mantmals, reptiles, or molluses has undergone the slightest change (p. 151).

There are other kinds of isolation besides geographic, such as biologic, physiologic, sexual, or morphologic isolation. Professor L. Plate tells us that there are twelve species of albatrosses in the Sonthern hemisphere; nine or ten belong to the Australian region, and intermingle, except at breeding time, whon they become segregated in different localities, and mating is kept to the same species: thus the species are kept distinct (Kellogg's Dar winism To-day, p. 243).

Kellogg also mentions butterflies of one species which cannot all breed together, because some of the eggs from which they come are hatched in the spring, some in the summer, and some in the autumn (Ibid. p. 244). There are also some animals which have profound antipathies to niating with any but their own particular variety of the specics.

\section{Adaptation.}

UNDOUBTEDL very many of the changes both in plants and animals which have led to the production of varieties, or to supnosed new species, have been due to their possessing a tendency to adapt themselves to any new region into which they may have been introduced, or to any change of climate. 
Professor P. C. Nitchell's article l'ariation and Selection in the Encyclopcedia Britannica says: "With regard to adaptations, it is becoming more apparent, as experimcutal knowledge advances, that it is a fundamental property of erery living organism in every stage of its existence to display adaptive response to its environnent. To whit extent such responses are transmitted to offspring, and what part they play in the formation of the adaptive characters that are conspicuous in wany animals, remain dubious. But it is at least clear that natural selection can favour those individuals and those races which show the greatest power of responsive plasticity in the individual" (p.912).

Dr. Wallace, in The Itorld of Life, tells us how curiously species differ in the smallest adjacent areas: even in the same field, apparently alike in soil, in aspect, in contour of surface, every plot of 16 feet square has its indiriduality. Snlll differences account for this, such as moisture or atidity, more or less shade from hedges, trees, or roods; shelter from or exposure to winds, etc. He says: "Now this one fact of response to the minutest change of conditions in the arrangement of a few species over almost identical adjacent areas is as much a case of adaptation to the environnent through the mutual interaction of the varions species-a struggle for existence on the very smallest scale-as any of those larger and more complex cases which Darwin first made known to us" (p. 94).

In the same book lie speaks of the case of the Porto Santo rabbits (see p. 179), and shows how they may have become adapted to their new home partly by natural selection and partly by adaptation. "Their numerous enemies (hatvlis, falcons, etc.) would at first capture the larger, more bulky, and slower moving individuals, then the white or 
black specimens, who would be more easily seen and pounced upon. The process, continuously acting for a few generations, would result in a smaller and more dusky-coloured race. The continuous attack persisting, the size would again be reduced, and the most agile and rapid in movement would alone survive. Thereafter, the nocturnal habit would be acquired by the day feeders being almost exterminated, and owls. would probably alone remain as formidable enemies. Lastly, the extreme wildness, sensitiveness to danger, perhaps to noise or movement of any kind would be developed, while the reduction of the supra-orbital process (of the frontal bone) may perhaps have been beneficial by reducing the width of the head, and thus allowing them to enter small holes in the rocks more rapidly"' (pp. 129, 130).

The Rev. Professor G. Henslow, whose book present-day Rationalism Critically' Examined we have noticed on p. 146, would put aside natural selection as the cause of evolution, and would substitute adaptation, his botanical studies having led him to this conclusion. He says: "The environment really so acts upon plants that they all respond to its influence in a strictly definite and adaptive manner, so that they develop just those structures which supply them with the best possible conditions for flourishing under the circumstances"' (p. 170).

\section{Convergence.}

THE consideration of Adaptation leads us on to that of Convergence.

Convergence is a term used to designate the appearance in two forms, not nearly related, of similar characters, which have been developed as an adaptation to similar conditions, and are not derived from a common ancestor. Darwin says: 
"Animals, belonging to two most distinct lines of descent, may have become adapted to similar conditions, and thus have assumed a close external resemblance; but such resemblances will not reveal - will rather tend to conceal-their blood-relationship." He gives several instances of what he names "analogical resemblances" (Origin of Species, chap. xiv.).

In The Descent of Man he says: "All analogical resemblances, as of a whale to a fish, may be said to be cases of convergence; but this term has never been applied to superficial and adaptive resemblances" (p. 275).

Wasmann applies this principle of convergence to some of the resemblances between man and the apes, and asks: "Are these resemblances the result of close relationslip, or are they merely converging phenomena, duc, not to community of origin, but to adaptation to similar conditions of life or development?" (Modern Biology, p. 456).

And Dr. J. H. B. Kohlbrugge says, "When Keith declares that he can see no other way to cxplain the large number of characteristics common to man, gorilla, orang-utan, and chimpanzee, except by a common origin, it may be held, on the other hand, that such correspondence might be just as well explained through parallel-formation or convergence" (Die morphologische Abstammung des Menschen, p. 47).

Mr. Goodrich says in his Evolulion: "Occasionally evolution leads to convergence in function and structure. Then organisms and their parts may come to resemble each other, analogies are developed. Thus a burrowing snake like Typhlops, a burrowing lizard like Amphisbæna, or amphibian like Siphonops, acquire a resemblance to an earthworm; or again, among the Mammalia, the 'flying' squirrel, Pteromys, and the 'flying" 
phalanger, Petaurus, have become remarkably alike. Very striking also may be the analogous resemblance between two organs of different origin, but fulfilling the same definite function, as the eyes of Polychrete worms, of Molluscs, and of Vertebrates. Mimicry and protective resemblance also are special examples of convergence. Yet, however close the resemblance may be, it is generally essentially superficial, and the separate origin of two structures is usually betrayed not only by fundaincntal differences, but also by innumerable details" (p). 79, 80).

And in the article Evolution in the Encyclopodia Britannica we read: "Especially in the case of manifest adaptations, organs possessed by creatures far apart genealogically may be moulded into conditions that are extremely alike. Sir E. Ray Iankester's term, homoplasy, has passed into currency as designating such cases where different genetic material has been pressed by similar conditions into similar moulds."

\section{Correlation.}

Messrs. DEWAR AND Find say in The Making of Species: "We may define correlation as the interdependence of two or more characters. . . . It very frequently happens that one particular character never appears in an organism withont being accompanied by some other character which we should not expect to be in any way related to it" (p. 356).

Amongst the instances mentioned by various authors are the following:-

Pigeons with short beaks have small feet. Pigeons with long beaks have large feet.

Hairless dogs have imperfect teeth. 
White tom-cats with blue eyes are always deaf.

The development of the tusks in the boar varies with the development of the bristles.

'The development of horns in ungulates is always associated with the suppression of the upper canine.

In Paraguay, horses with curled hair occur, and these always have hoofs exactly like those of a mule, while the hair of the mane and tail are much shorter thay usual.

The skin and its various appendages, as horns, hoofs, hair, feathers, and teeth, are homologons parts, and are subject to very strange correlations in growth.

Among plants, parallel venation of the leaves is almost always correlated with monocotyledonous structure.

'The article Variation and Selection in the Encyclopedia Britannica says: "Much correlation is the inevitable result of organic structure. The various parts of a living organism affect each other in adult life and during growth. . . . It is now known that internal secretions, or hormones, pass into the blood from every organ and tissue, so reaching and affecting every part of the body."

\section{Unit Characters.}

True following is from The Making of Species: "Mendelian phenomena force upon us the conclusion that organisms display a number of unit characters, each of which behaves in much the same way as a radicle does in chemistry, inasmuch as for one or more of these characters others can be substituted without interfering with the remaining unit characters. . . Very varied have been the conceptions of the nature of these biological units. Almost every biologist has given a name to his particular 
conception of them. Thus we have the gemunles of Darwin, the unit characters of Spencer, the biophors of Weismann, the micella of Nägeli, the plastitudes of Haeckel, the plasomes of Wiesner, the idioblasts of Hertivig, the pangens of De Vries, and so on.

Almost every investigator of the phenomena of inheritance believes in these units, and calls them by a different name. Morcover, each clothes them with characteristics according to his taste or the fertility of his imagination" (pp. 151, 152).

The article Hercdity, in the Encyciopedia Britannica, gives the following summary of Weismann's Germ Plasm theory: "The mass of germplasm, which is the starting-point of a new individual, consists of several, sometimes of many pieces named idants, which are either the chromosomes into which the nuclear material of a dividing cell breaks up, or possibly smaller units named chromomeres. Thése idants are a collection of 'ids," which Weismann tentatively identifies with the microsomata contained in the chromosomes, which are visible after treatment with certain re-agents. Each id contains all the possibilities-generic, specific, individual-of a new organism, or rather the directing substance which in appropriate surroundings of food, etc., forms a new organism. Each id is a veritable microcosm, possessed of an historic ar chitecture that has been elaborated slowly througli the multitudinous series of generations that stretch backwards in time from every living individual. This microcosm, again, consists of a number of minor vital units called 'determinants,' which cohere according to the architecture of the whole id. The determinants are hypothetical units corresponding to the number of parts of the organism independently variable. Irastly, each determimant consists of a number of smaller hypothetical units, the 'biophores.' (Vol. xiii., pp. 351, 352). 


\section{Pangenesis.}

IN Darwin's Variation of Animals and Plants he explains his theory of Pangenesis, by which be attempted to solve the problem of how, "in the case of all higher animals and plants, a single cell is able to separate itself from amongst the millions of most various kinds of which an organism is composed, and by division and complicated differentiation to reconstruct a new individual with marvellous likeness, unchanged in many cases, even throughout whole geological periods." Dr. Wallace says the theory "supposed that every individual cell in the body gave off gemmules or germs capable of reproducing themselves, and that portions of the germs of each of the almost infinite number of cells permeate the whole body and become collected in the generative cells, and are thus able to reproduce the whole organism" (Daruinism, p. 438).

Dr. Wallace says: "This theory is felt to be so ponderously complex and difficult that it has met with no general acceptance among physiologists," and Kellogg speaks of it as "nearly discredited" (Daswinism To-day', p. 3).

KcCabe says: "The Darwin theory of Pangenesis cannot now be entertained."

\section{The Origin of New Characters.}

ONe of the great difficulties of the Natural Selection theory has always been to account for the beginnings of entirely new organs in animals.

Professor Kellogg says: "Numerous useful characteristics or adaptations of organisms are useful only in a highly perfected state, often involving a complex and considerable structural development of old (then much modified) or quite new parts, and hence could not have arisen by gradual modification by the selection of slight variations. . . The 
electric organ of the torpecioes,... the chameleon's tongue, and many other organs can be recalled which could not possibly exercise their particular advantageous function in an undeveloped and beginning state" (Darwinism To-day, p. 49).

Mlessis. Dewar and Finn say: "A very serious objection to the Darwinian theory is that the beginning of new organs cannot be explained by the action of natural selection or fortuitous minute variations, and natural selection can act on an organ only when that organ has attained sufficient size to be of practical utility to its possessor. . . How can we explain the origin of an organ, such as a limb, by the action of natural selection on minute variations?" (The Making of Species, p. 36).

'This is, of course, a large subject, and it is impossible within our limits to treat it fully.

\section{Telegony.}

THEHCONY is a name given to the theory that of spring sometimes inherit characters from a previous mate of the mother. This is generally believed in by the breeders of dogs, and also of horses. Agassiz, Darwin, Herbert Spencer, Romanes, and other authorities were firm believers in this doctrine of "infection," and a special instance of a chestnut mare, belonging to Lord Morton, having first mated with a quagga, a South-A frican horse-like animal, and having afterwards produced to a black Arabian horse three foals showing a number of stripes similar to those in the quagga, was cited in proof by several writers on heredity. Recent experiments, however, entirely fail to confirm the theory (Encyclopedia Britannica, Vol. xxvi., p. 510).

\section{Animal Coloration.}

THE subject of the coloration of animals, birds. and insects, including Mimicry, is an attractive one, 
and it is treated in many popular books and magazine articles. Perhaps the clearest exposition of the Neo-Darwinian view will be found in chapters viii., ix., and $x$. of Dr. Mallace's Darinism.

Dr. Wallace draws attention to the close relation that exists between the colours of animals and their environment: white prevails among arctic animals, yellow or brown in desert species, while green is only a common colour in tropical evergreen forests. "In the arctic regions," he says, "there are a number of animals which are wholly white all the year round, or which only turn white in winter. Among the former are the Polar bear and the American Polar hare, the snowy owl and the Grecnland falcon; among the latter the arctic fox, the arctic hare, the ermine, and the ptarmigan. Those which are permanently white remain among the snow all the year round, while those which change their colour inhabit regions which are free from snow in summer . . .

"The lion, the camel, and all the desert antelopes have more or less the colour of the sand or rockanong which they live. 'The Eigyptian cat and the' Pampas cat are sandy or earth-coloured. ... Birds are equally well protected by assimilative hues; the larks, quails, goatsuckers, and grouse, which abound in the North African and Asiatic deserts, are all tinted or mottled, so as closely to resemble the average colour of the soil in the districts they inhabit" (pp. 190, 192).

"Anong our native birds we have the snipe and woodcock, whose markings and tints strikingly accord with the dead marsh vegetation among which they live; the ptarmigan, in its summer dress, is mottled and tinted exactly like the lichens which cover the stones of the ligher mountains; while young unfledged plovers are spotted so as exactly to resemble the beach pebbles among which they crouch for protection"' (p. 199). 
These colours are looked upon as protective. 'They favour the concealment of the more defenceless animals from their enemies. And the arguinent is, that out of a multitude of animals of each species born in the past, those only have survived which were of a colour that rendered them inconspicuous, and that this is a proof of the Natural Selection theory.

\section{Recognition Marks.}

But this will not hold good in all cases, and Dr. Wallace has been the chief advocate of an auxiliary theory-that in many cases of organs of a conspicuous colour they serve as "recognition marks," which for a herd of animals form a rallying point to keep them together, or to direct their course in fleeing from danger. The rabbit's. white tail is supposed to be a guide to its young ones when an enemy is in sight, and so it is that the white-tailed rabbits have survived, wheri, in past times, others perished.

\section{Mimicry.}

MIMICRY is a fascinating subject. It is a form of protective resemblance in which one species so closely resembles another as to be mistaken for it. Butterflies and moths afford some of the most striking instances of mimicry; even those which are adorned with the most brilliant colours or conspicuous markings.

Mimicry was once considered one of the inexplicable curiosities of nature, but it was explained by Mr. H. W. Bates, who accompanied Dr. Wallace in a voyage to the Amazons in 1848. Some insects have stings or poison fangs, or they are uneatable from their disagreeable taste, so they are never attacked. Where their colours render them conspicuous, so that they are avoided by their enemies, 
this is known as "warning coloration." But other species are so remarkably like many of these that they are said to "mimic" them. The Heliconidx family of butterflies, in tropical America, are a case in point; they have an offensive odour and taste, and thus are free from insectivorous enemies. They are mimicked by the family of the Pieridæ, and the explanation given of this mimicry is, that out of probably multitudes of varieties of this species in past ares, only those Pieridae which happened closely to resemble the uneatable Heliconidæe have escaped destruction.

Dr. Wallace mentions, amongst the vertebrata, harmless snakes which mimic poisonous species; he also mentions amongst birds the cuckoo, and some of the dull-coloured orioles in the Malay Archipelago.

Professor E. B. Poulton's Essays on Evolution is another book that gives much interesting information as to mimicry and protective coloration in insects.

\section{Criticism of the Theory.}

THE whole theory is, however, very strongly criticised by Messrs. Dewar and Finn in chapter vi. of The Making of Species. While admitting its truth to a great extent, they think that it has been pushed to absurd lengths, especially by Dr. Wallace and Professor Poulton.

In regard to the whiteness of Arctic animals and birds, they say that this has been greatly exaggerated, and they give a longer list of those that are coloured, than of those that are white (p. 190).

They quote from the African Nature Notes and Reminiscences of F. C. Selous, who writes (p. 13): "Having spent many years of my life in the pursuit of African game, I have certainly been afforded opportunities, stich as have been enjoyed by 
but few civilised men, of becoming intimately acquainted with the habits and life-history of many species of animals living in that continent, and all that I have learned during my long experience as a hunter, compels ine to doubt the correctness of the now very generally accepted theories that all the wonderfully diversified colours of animals-the stripes of the zebra, the blotched coat of the giraffe, the spots of the bushbuck, the white face and the rump of the bontebok, to mention only a few-have been coloured either as means of protection from enemies or for the purpose of natural recognition by animals of the same species in times of sudden alarm."

Mr. Selous says again: "Nothing is more certain than that all carnivorous animals hunt almost entirely by scent until they have closely approached their quarry, and usually by night, when all the animals on which they prey must look very much alike as far as colour is concerned."

Messrs. Dewar and Finn say: "It is, to say the least of it, significant that all the opposition to the theory of protective coloration comes from those who observe nature first hand, while the warmest supporters of the theory are cabinet naturalists and museum zoologists"' (p. 198). They refer frequently to their own observations in India.

Their chief contention is that the facts of Animal Coloration do not lend their support to the Natural Selection theory.

Then they say : "The theory of recognition markings must, we fear, be laid to rest in the burial ground of exploded hypotheses" (p. 275).

Professor Kellogg, in his Darinism To-day', also, to some extent, criticises the theory of "Protective Resemblance" among insects, and he instances the famous Kallima butterfies of the Malayan and south tropical regions, which show such a marvellous 
initation of a dead leaf. But it simulates the dead leaf with such fidelity in colour, shape, and intimate details of pattern, such as veins, flecks, fungus spots, etc., as to make it impossible to belicve that this is a result of Natural Selection (pp. 53 and 175).

\section{The Protozoa.}

I'HE Protozoa are, as their name implies, the first living things of which we have any knowledge.

Protoplasm, according to Huxley's definition, is "the physical basis of life." The "cell" (to quote from (roodrich) is a small mass of protoplasm consisting of a nucleus and surrounding cell-body. All plants and aninals are made up of such cells. Growth is due to the increase of size and multiplication of the cells.

The characteristic of the protozoa is that they are unicellular animals - the individuals being always a single vital unit or cell : in contrast with the higher division of the animal kingdom, the Metazoa, in which the individuals are generally multicellular, the body of each being composed of many cells.

Professor Minchin tells us, in his article Protozoa in the Encyclopcedia Britannica, that to separate by hard-and-fast definitions these unicellular animals from the unicellular plants, the Protophyta, is practically impossible. Then there are the Bacteria, which stand sharply apart from the other forms of life. Haeckel has suggested the name "Protist" to include all these primitive forms of life.

Professor E. W. MacBride, in his Zoology, takes rather a different view, and prefers to call the Protozoa non-cellular (p. 18).

Many of the Protozoa live as parasites of other animals, and, as such, inay be the cause of dangerous diseases and epidemics.

The Amceba (Gr. "changing") is perhaps the 
best known of the Protozoa, possibly because the term is often used in a more general sense, and also because many Protozoa are said to pass through an Amoba stage.

Wasmann says: "The body of the Amoba is subject to constant changes of shape, whence the creature has received its name. It can protrude protoplasmic continuations of its substance in all directions, and again withdraw them. The pseudopodia (i.e., false feet) are outstretched to catch food and to effect a change of place; they are withdrawn when any danger threatens. . . When the pseudopodia discover anything edible they close round it, and it at once becomes the centre of a vortex of protoplasm; the creature's whole body contracts round its prey.

The same protoplasm which sought and captured its food now proceeds to assimilate it, and digests as much of it as is digestible, and then rejects the rest by uncoiling the enclosing ring of protoplasm" (Modern Biology, p. 72).

We must understand that most of the Protozoa can only be seen through the microscope.

Messrs. Geddes and Thomson say in Evolution: "In a startling phrase-the immortality of the Protoroa-Weismann called attention to the fact that unicellular organisms are not subject to natural death in the same degree as higher animals are. They may be killed, of course, in many ways, but they do not normally die. . . In natural conditions, where intercrossing, for instance, is readily feasible, they appear to be exempt from that natural death which in the higher organisms is due to the slow mounting-up of physiological arrears" (p. 87).

Weismann says that according to the theory of evolution the whole realm of creation as we see it now, with man at its head, has evolved from the Protozoa, or perhaps even smaller and simpler or- 
ganisms (The Evolutionary Theory, Vol. I., p. 2).

The Harmsworth Encyclopedia says:" "No evolutionist doubts that the Metazoa have arisen from protozoon ancestors." But further on it refers to two sets of facts which "suggest that Metazon and Metaphyta alike have arisen from protozoon ancestors by many lines of descent," and it says : "This, however, raises a question which is sometimes put forward as a difficulty in regard to the evolution theory: if higher organisms have arisen, not from one but from many protozoon types, how is it that since the formation of the great animal and plant phyla at a remote geological period the existing Protozoa have given origin to no new stocks?"

In a disçussion at the Victoria Institute, in Feb. ruary, 1915, I asked a question somewhat similar of Professor Ernest W. MacBride, who had read a paper on The Present Position of the Theory of Organic Evolution. I said: "May I enquire whether recent researches have shown that the Amcba, which is to be found in all parts of the world, ever evolves into an organism of a higher character? . . If the Amœba in past ages evolved into higher organisms, what reasons can be given why it is not doing so now ?"

Professor MacBride's reply was: "With regard to Amoba, I was asked, if my views are correct, why it does not evolve now. All naturalists, including Professor Bateson himself, are agreed that there has been evolution. If evolution has taken place, the most probable supposition is that it occurred by the spreading of the species into new environment, and in the beginning of things there was plenty of new enviromment for simple protozoa to spread into, but the field is now occupied by higher forms." (Transactions of the Victoria Institute, Vol. xlvii., p. 123). 
The Harmsworth Encyclopadia suggests much the same answer to the problem.

Dr. R. C. Macfie, in Science, Matter and Immortality, says. "How is it that we have still amobæ which have not evolved at all? Here is an amœba and here is a man. Can any sane thinker affirm that one amoba remained constant to type, while the other has, by its own inherent power, become fish, monkey, or man? We liave really no reason to suppose that the offspring of amœbæ could in any number of generations become mammalian vertebrata."

Professor Hamann, in his Entwicklungslehre und Darwinismus, contends that "there cannot have been an origin of higher types from types already finished," and he says that the Amoba is so exactly adapted in organisation and functional activity to the conditions of its existence that it is a "finished" type. He says it is impossible to derive Mctazoa from Protozoa in their present finished state of evolution (Otto's Naturalism and Religion, p. 122).

Professor Ninchin's articie Protozoa in the Encyclopedia Britannica concludes by saying that the origin of life is veiled in a mist which biological knowledge in its present state is unable to dispel.

\section{Multiple Origin of Life.}

In chapters xii and xiii. of The Origin of Stecies Darwin discusses the question as to whether there were many "Centres of Creation," as he phrases it, though he apparently means centres from which evolution proceeded, and he goes fully into the subject of the means by which animals and plants can have been dispersed to different parts of the world on the supposition that all of one species or all of one genus proceeded from a single birthplace, and he relies very much on our ignorance of the 
means of dispersal in past ages. But it will be observed that this is another argument from the absence of facts.

Later on he says: "No doubt it is possible, as Mr. G. H. Lewes has urged, that at the first eommencement of life many different forms were evolved, but if so we may conclude that only a very few have left modified descendants" (ch. xv.).

Dr. Bastian's vicw, as quoted by Dr. Dukinfield Asticy, is as follows: "Instead of believing with Darwin that 'all the living forms of life are the lineal descendants of those that lived before the Cambrian epoch,' and that 'all the organic beings which have ever lived upon the earth may be descended from some one primordial form,' we must admit that life originally started from multitudes of centres; that from the earliest stages of the earth's history up to the present, new starting-points of simplest form have been ever taking place all over the surface of the earth." (Prehistoric Archeologv, p. 64.)

In Professor W. Bateson's Presidential Address at the British Association at Melbourne in August, 1914, he said :

"We should be greatly helped by some indication whether the origin of life has been single or multiple. Modern opinion is perhaps inclining to the multiple theory, but we have no real evidence."

Professor D. H. Scott, President of the Linnean Society, says: "As all admit, we know nothing of the origin of life; consequently, for all we can tell, it is as probable that life began, on this planet, with many living things, as with one. If the furst organic beings were many, they may have been heterogeneous, or at least exposed to different conditions from their origin; in either case there would have been a number of distinct series from the beginning, and if so, we should not be justified in? 
assuming that all organisms are related to one another. There may conceivably be several of the original lincs of descent still surviving, or represented among extinct forms. . . However improbable this may sound, the possibility is one to be borne in mind" (Darwir and Modern Srience, p. 202).

Dr. Oskar Hertwig, Director of the AnaramicalBiological Institute of the University of Berin. expressed a similar opinion in an address in 1900 on Biology in the Nineteenth Century: "If we would form an hypothesis as to the descent of the present world of living organisms from simple original cells in the carliest times, the polyphyletic hypothesis has certainly much more probability than the monophyletic"' (p. 44).

Dr. J. Reinke, of the University of Kiel, says : "Our first question of the evolution theory is whether, after the cooling of the earth's surface, one, several, or very numerous original cells bave appeared on it. . . We must consider it very improbable that unly at one single point in the earth one single cell has appeared; the prospect that it would keep alive and multiply would be of the slightest. But if there were several, say even a dozen, original cells, we could not speak of the blood-relationship of all plants and animals; and if several original cells, why not millions?" (Principles of Biology. Heilbronn. 1909. p. 170).

In a discussion, already mentioned, that followed a paper read by Professor E. W. MacBride before the Victoria Institute, I quoted some of these opinions, and in his remarks on the ciscussion, the Professor said: "As to the quotation from Dr. J. Reinke, I may say that all this is true. But the fundamental similarity in protoplasm, wherever found, suggests unity of origin. Even if different living cells appeared at once, if they arose in con- 
scritence of the same processes operating on the same material there would be a similarity of constitution amounting to blood-relationship."

But does not this upset altogether the ideas of evolution wave gained from Darwinian teaching ? Does it not undermine most of the evidence we have been taught to look upon as proving evolution - the evidence especially from geographical distrihution, and from the succession of living forms? If the facts that biologists have of late years been able to collect point to life having commenced at a multitude of different centres on the earth, instead of at one, or, as Darwin supposed, at four or five, what is there to show us that these facts point to evolution rather than to creation?

\section{Teleology.}

'THE argunent for the existence of a Creator from the evidences of design or purpose to be traced throughout Nature is called the teleological argument (Gr. telos, "an end").

Dr. Wallace, in The World of Life, notwithstanding the vagueness of his recognition of the God of Nature, has chapters on the proofs of an "organising and directive life-principle" afforded by birds and insects especially, and on the preparation of the earth for man, and he says: "What we absolutely require and must postulate is a Mind fur higher, greater, more powerful than any of the fragmentary minds we see around us-a Mind not only adequate to direct and regulate all the forces at work in living organisms, but which is itself the source of all those forces and encrgies, as well as of the more fundamental forces of the whole material universe" (p. 338).

This is really the guiding thought throughout this splendid book-the last work of one of the formost scientific men of the last half-century. 


\section{Conclusions.}

WE are now in a position to sum up the results of our criticism of evolutionary theories.

Our readers must consider themselves a jury who have to give a verdict on the evidence brought before them. We are none of us experts, but juries are frequently called together to decide on questions - often of life or death-on the evidence of experts.

The subject is such a complicated one that it will be found impossible to form a clear judgment without some painstaking examination of the different points at issue. The quotations given in this book are all from works of some authority, and further information can be had, if needful, by consulting thein. Very. many of them are obtainable in cheap editions.

The theory of man's descent from animal ances. tors has usually been advocated from the evidence afforded by the prehistoric remains of man, and by an examination of the body of man as he now exists.

We have chiefly to consider :-

The skulls and skeletons of ancient man, including those that have been known as "missing links."

The alleged rudimentary or vestigial organs in man's body, supposed to be useless, or even harmful.

The similarities between the body of man and that of the present anthropoid apes.

The evidence of Embryology, or the Recapitulation Theory.

The evidence of Geology as to the antiquity of man.

The evidence of flint and stone implements which it is claimed have been fashioned by ancient man. 


\section{Prehistoric Skulls and Skeletons.}

WE must clearly understand that the "missing link" theory is now entirely given up. Professor Keith shows in the last chapter of The Antiquity of Man that the discoveries made in the present century prove that men of the modern type,.." if not actually the contemporaries of Neanderthal man, were so closely his successors in point of time that it became impossible to believe that Neanderthal man represented a stage in the evolution of modern man."

Notwithstanding this, the books on evolution most easily accessible to students, and some books published since Professor Keith wrote this in 1914, know nothing of this revolutionary change in the argument, and still treat many ancient skulls, etc., as "missing links." Casts of several of the principal prehistoric skulls can be seen in the Natural History Museum at South Kensington, but the references made to them by Mr. McCabe and Dr. Woods Smyth (see p. 31) apparently give a somewhat wrong impression.

The position now taken up by Professor Keith is that the Neanderthal skull and others were representative of races originating from animal ancestors, but whose descendants have all died out, and on the supposed resemblance of these skulls to those of the ape, he asks us to believe that all other prehistoric skulls, though quite of the type of modern man, were those of men descended from an animal stem.

In the early pages of this book some brief particulars are given of all the prehistoric human remains mentioned in Dr. Keith's Antiquity of Man, and fuller details, with the opinions of various biologists and anthropologists, are added in regard to those which he thinks afford proof of similarity 
to the ape-world. These are the Pithecanthropus of Java, the Eoanthropus of Piltdown, the Neanderthal man, the Spy skeletons, and others classed as belonging to the Neanderthal race.

In regard to all the most important of these, it will be noticed that the most diverse judgments have been passed upon them by different scientific men.

Pithecanthropus was declared by Professor Virchow; after a most careful examination, and after a very full discussion at the Berlin Anthropological Society, to be an ape.

We have seen (pp. 34,35 ) that this view is supported by Professors Richard Hertwig, Macnamara, Branca, Hamann, Bumüller, Ranke, W. Krause, and even Klaatsch, and by the Rev. E. Wasmann. Then, in a recent pamphlet, Primitive Man, Professor Elliott Smith says that "several leading palæontologists, such as Professors Boule and Obermaier, still maintain that Pithecanthropus was really an ape" (p. 8), and in his paper on Early Man, in the Geological Magazine for January, 1917, Dr. Smith Woodward, who has recently examined their arguments, says that there is some reason to suspect that the Java specimen was "really a gigantic and precocious gibbon."

Eoanthropus is admitted by Dr. Keith to be at human being of quite modern type, except as regards the mandible or lower jaw, only the right half of which was found, and some of the teeth. The skull was recovered in several fragments, some in the autumn of 1911, and the rest, with the jaw, six months later. There is a contest anongst the authorities as to whether this jaw belonged to the skull, some American naturalists being strongly of opinion-as was Professor Waterston-that it belonged to a chimpanzee, or to some anthropoid; while Mr. W. P. Pycraft, in opposing this view, 
admits that the skt1l, even with the jaw, was less ape-like than that in many modern men.

Of the Neanderthal man many different opinions were formed by different scientists, and there was no clear evidence as to the geological age to which the reinains belonged. Professor Virchow declared that the abnormal appearance of the skull was due to disease. $\mathrm{He}$ also said that he had seen many modern men with similar skulls.

Wasmann says: "It has fallen to the lot of this Neanderthal man to be described variously as an idiot, a Mongolian Cossack, an early German, an early Dutchman, an early Frieslander, a connexion of the Australian blacks, a palæolithic man, and a still more primitive ape man. The remains of his skeleton clearly are of a nature to admit of many interpretations, and each student can make of them whatever he wishes" (Modern Biology, p. 468).

It was the discovery of the Spy skeletons near Liege in 1886 that gave the chief support to the theory of a Neanderthal race of men. So much has been made of the evidence afforded by these remains that it has been felt important to give a translation of the earliest report made by $M$. Lohest and $M$. de Puydt upon them, and the original French is given in Appendix ii. This report shows how very imperfect the remains were; one skull was broken into about forty pieces, and as to the other, the admission must be specially noticed that "in the lower jaw, as the extremities of the coronoid apophyses and the condyles were wanting," the important question of facial prognathism could not be decided.

Then the Report gives a long list of miscellaneous bones that were discovered, but in regard to which it was impossible to assign them to the right skeleton. (See Appendix.) 
Professor Virchow saw the skull when it had been reconstructed, and showed that a mistake had been made as to one of the bones, and this mistake was admitted, but it was too late to remedy it. Professor Virchow, in one of the last scientific meetings in which he took part, gave it as his opinion that the Spy skulls were those of ancient Frisians.

Of the great importance of the opinion of Professor Virchow on the Pithecanthropus, the Neanderthal man, the Spy skulls, and the Naulette and Schipka remains, there can be no question. For over thirty years he presided over the debates of the Anthropological Society of Berlin, where questions as to skulls from all parts of the world were constantly being discussed. Herr A. Lissauer says of him : "To estimate rightly the services of Virchow as an anthropologist, the whole history of anthropology would have to be written."

\section{Geological Age of Remains.}

THE geological age of the strata in which remains were found is in many cases by no means clear.

Martin, Volz, and Elbert, by their investigations of the Trinil strata, have quite disproved the tertiary age of Pithecanthropus.

As to the Neanderthal man, there is nothing but uncertainty.

As to the age of Eoanthropus, Professor Osborn says he does not agree with Dr. Smith Woodward in placing it in early Pleistocene times, and he adds : "The difference between early and late Pleistocene times is not a matter of thousands but of hundreds of thousands of years" (Preface to Men of the Old Stone Age). (Of course we need not accept these high estimates of time.)

Professor Hugues Obermaier and Professor Osborn dispute the age of the Spy skeletons, and the 
former, at all events, would bring them down to a post-glacial age (p. 49).

As to the Gibraltar skull, which, after being neglected for more than half a century, is now claimed as a Neanderthal specimen, nothing whatever is known about the geological age of the strata in which it was found.

The details given on pages 27 to 29 and 50 to 54 of this book as to other so-called Neanderthal remains will show that the fractured state of most of the skulls, and the difficulties of reconstruction, make it hardly possible to draw any satisfactory conclusion from them. And then we have seen that there are some writers who attribute the special form of the skulls of these "Neanderthal" men to their mountain life, or to a special form of disease.

As to the Mauer jaw, of which so much has been made, we shall notice the warning of Professor Branca that the whole of a skull cannot be inferred from a jawbone.

Kramberger has shown that the Heidelberg jawbone very closely resembles that of a modern Eskimo skull, and Obermaier and Wilser have questioned the geological age of the strata in which it was found (Modern Biology, pp. 506, 507).

Branca shows that nowhere has a human skeleton been found that in the relative size of arms and legs reminds us of the specially distinctive characteristics of the anthropoid apes: very long arms, short legs; but that the fossil skeletons found are in this respect entirely human (Fossil Man, p. 7).

We may notice here that Professor Osborn says in his preface to Men of the Old Stone Age: "No doubt our ancestors of the early stone age were brutal in many respects, but the representations which have been made, chiefly by French and German artists, of men with strong gorilla or chim- 
parzee characteristics are, I believe, unwarranted by the anatomical remains."

\section{The Neanderthal-Spy Race.}

If we put aside Pithecanthropus and Eoanthropus, Professor Keith's arguments for the animal descent of man from fossil human remains rest entirely on the Neauderthal race. It is only since writing the carlier part of this book that I have seen a very important article by Professor Kollwanu, of Basle, who has riade a special study of very young apes-chimpanzees and the anthropoids generally - and also in some cases of embryonic forms, and he brings the results of this study to bear on questions of variability and convergence, and comes to conclusions which matcrially affect the view to be taken of the so-called Neanderthal race.

He says: "If variability is so considerable that dolicocephalic and bracycephalic skulls arise, there is in my view a probability that the retreating forehead and the projecting orbital ridges of the Neanderthal group perhaps belong to the category of phenomena which must indicate individual variations of Homo sapiens. . . In the far-distant Continent of Australia just as strongly marked orbital ridges and retreating brows are to be found as in the skulls of the Neanderthal-Spy group. Spencer and Gillem give the portrait of an Australian whose retreating brow and strongly marked orbital ridges are clearly like those of the Neanderthals. . . The old skulls of the Diluvium show great variability, but offer no proofs of the existence of a special species (of man). No marks of blood-relationship are here before us, but marks of convergence. Biology and Phylogeny, which have made such important advances in the last ten years, have brought valuable insight into con- 
vergence appearances, which have often been erroneously taken for marks of affinity."

Professor Kollmann then gives instances of convergence in animal life, and he comes at the end of his paper to the following conclusions:- "The projecting orbital ridges and the retreating brows of the Neanderthal-Spy group are extreme forms of variability in the white races of Homo sapiens, but are to matks of a special race.

"The similar characteristics in the Anthropoids of the present day, in Pithecanthropus, and in Europeans and Australians rest upon convergence-phenomena, and are no marks of descent" (Archiv jür Anthropologie, Vol. v., October, 1906, D. 208 et seg.).

\section{Rudimentary Organs.}

As to the rudimentary or vestigial organs which, according to the view held by Professor Drummond, are useless relics left in the body of man from an animal ancestry, we find to-day from the admissions of some biologists and the criticisins of others that the very organs supposed to be harmful are now bcing recognised as beneficial, and there is surely nothing to be said after the opinion of Mr. Goodrich in his Evolution: "He would be a rash man indeed who would now assert that any part of the human body is useless."

And Darwin said, in The Descent of Han: "Various other anomalies in man .. have been advanced by different authors as cases of reversion; but these seem not a little doubtful, for we have to descend extremely low in the mammalian series before we find such structures normally prescrit' (p. 59).

The Recapitulation Theory, which is responsible for very much that has been advanced as to the 
supposed vestigial organs in man's body, has been very fully considered on pages 75 to 82 .

Professor Bateson, in his Matcrials for the Study of Evolution, says, in discussing this subject: "TVe are endeavouring by means of a mass of conflicting evidence to reconstruct the series of Descent, but of the laws which govern such a series we are ignorant." He says also: "It will, I think, before long be admitted that in this attempt to extend the general proposition to particular questions of descent the embryological method has failed. . . The principle of $v$. Baer was never more than a rough approximation to the solution of particular problems. It is curious to notice upon how very slight a basis of evidence this widely received principle rcally rests. It has been established almost entirely by inference, and it has been demonstrated by actual observation in scarcely a single instance" (p. 9).

These admissions are of the utmost importance when we remember the arguments that have been drawn from embryological evidence by Darwin (Origin of Species, ch. xiv.) and many other writers. Professor Bateson's opinion is that, on the whole, the facts of Embryology do support the doctrine of community of descent (i.e., of Evolution generally), but that the attempt to extend the general proposition to particular questions of descent has failed. 'Thus, in Professor Bateson's view, no argument could be drawn from embryology as to the descent of man from the animal.

As to the similarities between the body of man and that of the ape, the opinions of many German biologists, to be found on pages 82 to 86 , will show that there is another side to the question. As regards the blood of man and the blood of the anthropoids, special attention must be given to the admissions of Professor Nuttall as to the elements of uncertainty attending his experiments (p. 65), and also 
to the new discovery as to the relation between the blood of animals generally and the skeleton (p. 68).

But what Professor Virchow says as to man having an animal organisation must always be borne in mind (see pp. 73, 74). And let us notice what is said in Human Osteology as to man being the only mammal who can stand on one leg!

\section{Dr. Keith's New Theory.}

Avy argument drawn from similarities between man and the ape must surely be seriously weakened by the new hypothesis which Professor Keith has been compelled to adopt through the failure of the "missing link" theory. For when we have to imagine the branching off of the "humanoid" stem which led to modern man in some far remote geological period, does it not reduce to an absurdity the idea of small muscles in the neck and arm, and in the calf of the leg (The Human Body, pp. 86, 87), persisting on the one hand in the monkey tribe, and on the other hand in man, through all the immense changes that, it is freely admitted, would be needed for his evolution from the ancestral ape?

In this connection the remarks of Professor J. A. 'Thomson in his Heredity' as to supposed reversions to ancestral characters which are much more likely to be independent variations should be specially noted.

He says: "It is always possible that a variation really occurring de novo, and apart from latent characters, may happen to coincide with an ancestral trait. It may be described as a reversion, but is really an independent variation" (Heredity, p. 129).

Again, he says: "It is possible that many so-called reversions may be simply Mendelian phenomena in disguise" (p. 134).

And then comes the exceedingly important question, How could it have come to pass that man's 
bodily framework assumed its present form so many ages ago, while as regards many small muscles he is unchanged? The idea secnis incredible.

\section{The Ancestral Ape Theory.}

$W u$ have seen that biologists quite agree that man has not descended from any of the present anthropoid apes: we have noticed also bow scanty are the fossil remains of any species of anthropoid in the older geological strata. We have seen, further, that Haeckel's fantastic speculations as to man's descent are rejected by the more cautious biologists. What we have now practically to deal with is the theory that man originated from some ancestral species of ape of which no fossil relics have been found.

Here we very naturally ask the evolutionists for some reasonable theory as to how the change fron ape to man was brought about-in the first place as to the order in which changes in brain, band, foot, limbs, tecth, bodily posture, occurred; how man lost his hairy covering, and acquired his gift of language; to say nothing of those mental and spiritual characteristics which totally differentiate him from the animal.

On all these points we get from various writers only very vague suggestions, with some that are really absurd.

Professor H. F. Osborn says: "Man emerges from the vast geologic history of the earth in the period known as the Pleistocene, or Postglacial, the Diluvinm of the older geologists" (Men of the Old Stone A ge : Intro. p. 18).

The word emerges does not give us a very definite idea of the process!

Professor Keith says: "But of that great welter uf forms one species became the dominant form, and 
ultimately the sole surviving one-the species represented by the modem races of mankind.'

Aetchnikoff, in the third chapter of The Nature of Man, in speaking of the sudden origin of a new species of the Evening Primrose of De Vries, says: "It is probable that man owes his origin to a similar phenomenon; some anthropoid ape having at a certain period becone varied in specific characters, produced offspring endowed with new properties."

He then refers to the fact that from time to time prodigies are born with greater talents than possessed by their parents, and cites the case of Jacques Inaudi, a native of Piedmont, who had wonderful powers of calculation, and at the age of 11 astonished the members of the Anthropological Society of Paris by sis $^{2}$ calculating powers. He says: "The first men were probably prodigious children, born of anthropoid parents."

We are rather surprised, from such an cuinent writer as Professor $\mathrm{J}$. Arthur Thomson, to read in Darwisism and Human Life: "To begin with, man probably arose by a mutation, that is to say, by a discontinuous variation of considerable magnitude. Every one who has known a genius has in this happy experience some idea of what is meant by a mutation, thongh the comparison breaks down, inasmuch as the guality of genius is rarely heritable. It is not merely that the genins has more brains; he has a new pattern of brains, and a large mutation is a new constitutional pattern. It is likely that man had his starting point as a prepotent anthropoid genius" (p. 123).

Professor Elliott Smith says, in Primitive Man: "The earliest members of the human family must have been merely apes with an overgrown brain, and probably the first bodily changes that occurred were the modifications of the legs for the new methods of 
progression, which were in the main the outcome of the higher development of brain" (p. 10).

But an indefnite suggestion of this kind does not meet the practical difficulties, which, when we look at thém, are really formidable.

\section{The Miocene Gibbon.}

I's is fully admitted that man could only have attained his erect posture after changes affecting every bone, muscle, joint, and organ in the whole body. To account for such changes, Dr. Keith has to resort to a supposition which he thinks probable: "It is very probable that a type of ape similar to the gibbon was evolved at the beginning of the Miocene period, or even before that period began. That is certainly many millions of years ago" (The Human Body, p. 75). It is the millions of years which are so often the refuge of the evolutionist: it is difficult to follow him so far back into the unknown!

But even if we accept the Miocene gibboll, and grant the millions of years, the difficulties shown by all the various German anthropologists cited in Professor Hamann's book (pp. 82-85) still remain. An enormous number of stages would have to be travelled in the journey from ape to man, and no hint is given us by the evolutionists as to the causes which could have led from one to another.

Now, for any variation of structure to survive, the same variation must have occurred in a male gibbon and a female gibbon at the same time.

Not only so, but a similar variation must have occurred at about the same period in a very large number of individuals of the gibbon family, unless there had been some means of isolation for the progeny of the first pair, othervise, as Professor Cope shows us, the variation would have been lost by interbreeding. 
How can we suppose any cause that would account for such a number of variations of the same character occurring amongst the gibbons at the same time?

And this would have to occur again and againsometimes, perhaps, a change in the brain, sometimes in the bodily structure, but always, in the long run, in the man-ward direction.

What reason can be assigned for such a series of changes?

And some form of isolation would certainly be needed sooner or later to prevent the new type of gibbons reverting through interbrecding to the ofd type. The circumstances secm to render any lind of geographical isolation very unlikely.

Then, also, at some stage there would come the question whether the new type, perhaps half gibbon and half man, could exist in quite the same environment as the old type-whether a new kind of food, a new kind of climate, or protection against new enemies, and perhaps conditions in manv ways different, might be necessary.

The crucial point must have come, we should imagine, when the gibbons of the new type left their tropical forest homes and had to adapt thentselves to life in the plains.

But supposing all the chinges to have come to pass, does it not occur to us what could possibly have happened to all the intermediate forms between ape and man that must at some time have existed? Why is it that there is not a trace of them amongst the fossils? And still more, we may ask, why have none of these intermediate semi-human forms persisted up to the present day? What can account for none of them leaving descendants? For very many varieties of the ape-world still exist, and while many of these would have perished in a different climate, man would not have been affected. 
To summarise these points : let us consider for a moment the hypothetical pathway from ancestrai ape to man.

Dr. Wallace tells us there must have been a score of stages on the road, but when Dr. Keith explains the numerous changes that would be involved, and the millions of years which would be required, we should rather say a hundred, especially as sometimes, instead of steady advance, there would have been retrogression.

But we cannot imagine any cause which, even at one of these stages, conld have produced the same variation in a large number of animals at the same time, and how could we inagine such a process a huadred times, or even a score of times repeated?

Neither can we imagine any means of isolation that whid keep the new breed pure, even for once, not to say a luindred times.

And total change of environment would sureiy very soon be needed, and indeed many times over during the millions of years, but how could it be found at the proper time?

But neither the supposed ancestral apes, nor the hundred hybrid forms which the theory surely reruires, have left the least trace of their existence amongst the fossils, neither can we in any way account for the total disappearance of all these hybrid forms from the earth, leaving no descendants.

Surely anyone who fairly considers the whole question must come to the conclusion that nothing

- less than a series of miraculous interferences by a power above nature could possibly have brought about the changes that would be required for the evolution of man from the ancestral ape without any irace being left of the process.

Does it not make it simpler if we can only believe that "the Lord God formed man of the dust of the 
ground, and breathed into his nostrils the brenth of life; and man became a living soul"?

\section{Early Man.}

THe antiquity of man, including the evidence afforded by the "Eoliths" and flint instrumerts. has been so fully discussed on pages 125 to 143 that it does not eppear necessary to repeat the arguments on the subject. The time that elapsed between the Flood and the entry of Abraham into Canaan is wholly uncertain, so that, as to this, the geological evidence in regard to the age of mas cannot contradict Scripture.

It is, of course, assumed by the evolitionist theary that the earliest men, just emerging from the animal condition, must have been very primitive savages.

But is not this quite negatived by what we know of the Cromagnon race?

It is a question whether the Cromagnons were not the earliest men of whom we have any certain knowledge, since we have seen how doubtful is the geological evidence as to the Neanderthal and Spy men, and Eoanthropus, and how strong is the proof that Pithecanthropus was not a man at all.

Professor Keith places the Cromagnon race, relics of whom we find in the Dordogne and elsewhere, in the Aurignacian period, and he says that the Abbe Breuil has proved that the Solutrean and the Hagdalenian periods came between this and the Neulithic period (The Antiquity of Man, pp. 54, 56i.

\section{The Palaolithic Artists.}

THE Encyclopadia Britannica, in the artici Archaology, in speaking of the recently extinct Tasmanians, says: "But the caves of France, of the same Palazolithic period, and used by men theoretic- 
ally in the same stage of culture, bring before us a race of artists of first-rate capacity, who for accuracy of observation, and for skill in indicating the character and peculiarities of the animals around them, have never been surpassed . . . We are dealing with human beings whose intellect, to judge by their physical characters, should be on a level with that of the Fuegian or the Australian black. . . . There are many astonishing problems in archaology, but none so badly in need of solution" (Vol. ii., p. 347). The article goes on to say that these artistic productions were due to the Cromagnon race.

Professor H. F. Osborn says: "The painting and drawings of Dordogne chiefly represent the mammoth, reindecr, thinoceros, bison, horses, wild cattle, ibex, and chamois. . . No artists have ever had before them at the same time and in the same country such a wonderful panorama of animal life as that observed by the Cromagnons. Their representations in drawing, engravings, painting, and sculpture afford us a view of a great part of the life of the period, including its contingent of forms from the tundras, steppes, Alpine summits, and Eurasiatic. forests and meadows" (Men of the Old Stone Age, p. 365).

Dr. Dukinficld Astley says : "There are drawings executed on the rock-surface of some of the walls in the very darkest recesses of the caverns, which can only be seen by artificial light. . . How they were ever done is a mystery, but that they were done with some object is certain. . . It may be argued with great plausibility that all these drawings testify to a religious instinct, and were done with some definite purpose, the exact import of which it is now impossible to determine" (Prehistoric Archceology', p. 138).

As regards some of the slicletons in the Mousterian and Aurignacian periods, where it was clearly a case 
of burial, Dr. Keith says: "Even at this early period a species or kind of man, not directly related to modern races, was burying the dead and furnishing thein with an outfit as provision for a long journey. The human mind, even then, held hopes and beliefs as to what happened after death" (The Antiquity of Mían, p. 117).

Dr. Astley shows that the artistic work of the Quaternary period must have been "the final outcome of a long progression," carried on through many generations, and he thinks it nrobable that it began in another part of Europe (Prehistoric Archceology, p. 106).

It seems clear, therefore, that these palæolithic artists must have had predecessors with the artistic instinct, going back for a number of generations, and if the Cromagnon men were not the earliest men of whom we can say that we have any positive knowledge, these predecessors must have been. The Neolithic peoples, who followed the Cromagnon race, though they had learnt something of agriculture, did not show the same artistic skill as their predecessors.

\section{Ancient Higher Civilisation.}

But there are not a few cases where, amongst the savage peoples of the present day, there are traces of some ancient higher civilisation. Easter Island, in the Pacific, 2,000 miles from South America, is one of the most remarkable instances. The natives, who are very few in number, are now Christians. The island, which is rather smaller than Jersey, is strewed with hundreds of carved stone images, some of them nearly 40 feet long, and many over 15 feet. They are now thrown from their pedestals, and lying in all directions, but many had separate stone crowns placed on their heads, the crowns being from two to ten feet across. In one 
part of the island there are remains of stone houses, nearly 100 feet long by 20 feet wide. The lava rocks near the houses are carved into the resemblauce of various animais and human faces.

Similar terraces and images have been seen in other islands now uninhabited. The ruins of ancient stone buildings of great extent are found in the Philippine Islands, the Ladrones, the Marshall and Gilbert groups, the Society Islands, the Navigators, and the Marquesas. The whole of North America, from the Gulf of Mexico to Canada, is full of ancient works of earth and stone, chiefly found in the form of mounds and embankments. . . Many of the enclosures are in the form of circles and squares, and in many cases these figures are so exact that they show mathematical knowledge. Then the mins of the exhumed cities of New Mexico are very extensive, covering hundreds of miles. (See Professor Orr's God's Image in Man, pp. 302, 303. He quotes from an address by Mr. A. J. Mott, at Liverpool, in 1873, of which a fuller account is given in Professor St. George Mivart's Lessons from Nature, pp. 149153.)

In the Sandwich Islands, Dr. Bastian foumd traces of descent from ancestors who in some way shared the bigher culture of the Asiatic nations (Nature. 1881, p. 29).

Dr. Tylor says: "In South-East Africa, a comparatively high barbaric culture, which we especially associate with the old descriptions of the Kingdom of Monomotapa, scems to have fallen away, and the remarkable ruins of buildings of hewn stone fitted without mortar indicate a former civilisation above that of the native population" (Primitive Culture. p. $39)$.

It is surcly clear, from these instances, that many sayage races must have been the degenerate descendants of more civilised ancestors. Then, in many 
cases, as we know full well, the work of Christian missionaries has been the means of their being raised again to a higher level.

Sir W. M. Ramsay, in the early part of his book. The Cities of St. Paul, discusses the question, "Is the modern savage primitive?" And he declares that all his experience and his reading show him notbing to answer the question in the affirmative.

\section{The Evolutionary Theory.}

THu latter portion of this volume has been occupied with a review of the theory of Evolution generally.

The Sunday School Times of Philadelphia, in its issue of 1st September, 1917, says :-

"There are few subjects about which so much has been said and so little is understood as the subject of Evolution. In the name of Evolution thousands of young men and women are rejecting the Bible as the Word of God. Many young ministers, and others preparing for the ministry, believe it necessary to revise their view of the Bible under the cornpelling power of the new ideas that Evolution has brought to men. An earnest young theological student-typical, doubtless, of hundreds more-recently said to a friend that the facts of Evolution were as assured as the law of gravitation, and he must adjust his ideas of the Bible to fit in with these facts.

The fundamental teachings of Evolution are made the basis of practically every text-book of science that is affected by the question."

It has been for many years my own strong conviction that some of the scientific theories of the day lie it the root of much of the unbelief in God's Word, and it is this conviction that has led to my writing the present volume.

The evolutionists fall, of course, into various classes. 
We have seen that Haeckel adopts Evolution as a part of his materialistic system, which is an entire denial of God. His pupil and translator, Mr. Joseph McCabe, follows on much the same lines in his Evolution from Nebula to Man, and The Principles of Evolution.

There are many other evolutionists who do not follow Haeckel in his speculations as to the universe at large, but who include man in their evolutionary scheme, and who, while they have to admit that Abiogenesis, or Spontaneous Generation from the inorganic world, is entirely unproven, look upon it as a logical necessity of their system, and suppose that it must have occurred at some period in the world's history.

At the meeting of the British Association at Dundee, in 1912, there was a discussion on The Origin of Life. Professor Schäfer presided, and there mere ten speakers. There were speculations as to whether life bad arisen from the organic world, whether it had originated in some other way on the earth itself, or whether it had been brought in some way to the earth from infinite space, but so far as the Times' report shows there was no mention even of the possibility that life was of Divine creation. What a contrast to the declaration of that eminent man of science, the late Lord Kelvin, who said: "Scientific thought is compelled to accept the idea of creative power." Lord Kelvin also said: "I am ready to accept as an article of faith in scicnce, valid for all time and in all space, that life is produced by life, and only by life."

There are other biologists who, while they extend their evolutionary scheme to include man, still desire to acknowledge the Creator. Professor IV. B. Scott, in his recent book, The Theory of Evolution (1917), speaks of Cuvier and Agassiz as having upheld the theory of special creation and the immuta- 
bility of species, and interpreted it as the carrying out of a systematic creative plan, and he says that this is "an interpretation which is not at all invalidated by the acceptance of the evolutionary theory" (p. 88).

Then we have the view of Dr. Alfred Russel IVallace and Professor St. George Mivart, who held that the body of man arose by evolution frorn the animal, but who contended for a Divine origin for his inental, moral, and spiritual nature.

\section{Evolution and Genesis.}

Dr. J. M. GraY, Dean of the Moody Bible Institute at Chicago, who is an eminent Bible student, and a strong upholder of the inspiration of Scripture, considers it possible that Evolution may be true in regard to all living beings, with the exception of man. He says in Bible Problems Explained:-

"The original creation of matter, the creation of the system of life, and the creation of man, are three distinct creations out of nothing. They are not simultaneous, but successive, and God's action in them is constant; therefore, evolution from one into the other, from matter into life, or animal life into spiritual life is impossible. Great thinkers, who are at the same time devout men, are willing to admit that there may be evolution within any one or each of these systems considered by itself; i.e., that matter may evolve itself into various forms of matter, and animal life into various forms of animal life, and human life into various forms of human life."

But there comes then the question of the exact meaning and force of the expression several times repeated in the first chapter of Genesis, "After his kind ; After their kind."

Dr. Bullinger says in a note in the Companion Bible: "Evolution has no answer to this." 
Dr. F. P. Ramsay, of Omaha, Nebraska, however, in An Interpretation of Genesis, translates the words "the different kinds," and says, "The meaning is not according to type (as the A.V. suggests), but in variety. Verse 11 says that God made all varieties or kinds of herbs and trees, and so in verses $21,25 . "$ The Variorum Bible gives as an alternative reading: "In the several kinds thereof."

\section{Evolution within Limits.}

Ir is certainly quire possible that Evolution may be true within certain limits, and that it is only the unfounded claims made for the theory that are really in opposition to the teaching of the Bible.

There are no writers who have done more to defend the inspiration of Scripture than the late Professor James Orr and Sir Robert Anderson.

Professor Orr, in Sin as a Problem of To-day, says: "The present writer. . has no concern to dispute evolution within the limits in which Science has established it, or rendered it probable. He would only plead for its being kept carefully within these limits, in its bearings on religion" (p. 131).

Sir Robert Anderson says, in The Bible and Modern Criticism: "In common with many other Christians I regard the Darwinian theory of evolution as being, within strictly defined limits, a reasonable hypothesis" (p. 117).

And we must confess that there are certain facts that render evolution, within limits, probable.

There are the facts of Artificial Selection. It is unquestionable that by the efforts of cultivators and breeders a large number of species of plants and animals have, within living memory, produced other forms, which have diverged widely from the 
parental stocks, and which, if their origin were anknown, pould be classed to-day by naturalists as entirely new species.

Then there is the fact that such a large number of species have become extinct during the geological ages. The eleventh and twelfth chapters of Dr. Wallace's excellent book, The World of Life, give an interesting account of the enormous animals of different kinds which inhabited the earth during the Tertiary Period, and before it, but which have all passed away. It is not unreasonable to suppose that, as such an immense number of species have become extinct, other species may have arisen to take their place.

We have secn (p. 178) that Dr. Wallace says that the total number of species that have lived on the earti nust be more than twelve times-perhaps 30 or 40 times-the number now living.

Then we cannot put aside the fact that such an inmense majority of the men of science of the present day-men tho have spent their lives in the study of Nature-are convinced as to the fact of Evolution having taken place, although they are horrelessly at variance as to the How.

We may remember, indeed, that there is a senic in which evolutionists (if we except the school of Hacckel) pay a tribute to the Bible. By their theory they seek for a law or principle running throughont all Nature. But for such a law there must be unily in Nature, which there could never have been if, according to heathen traditions, and the books of false religions, the origin of the world was due to a multitude of deities who were often even warring against one another. It is only the Bible that $t$ veais to us the ONE supreme Creator and Ruler of the Universe. We shall revert to this point when we ronsider the testimony of Science to Scripture. 


\section{A Recent Defence of Evolution.}

I'T is well to hear the latest word that can be said for Evolution, and this we find in a book by Dr. W. B. Scott, Professor of Geology and Palæontology in Princeton University, U.S.A. (one of the writers in the Darwin Centenary Volume), The Theory of Evolution (1917).

In the Preface, Professor Scott says: "My experience with graduate students of biology has shown me that usually their training has so completely taken for granted the truth of the evolutionary doctrine, that they have but a vague conception of the testimony by which that doctrine is supported." He writes to supply this evidence, but also to meet a "widespread belief that naturalists have become very doubtful as to the truth of the theory of evolution, and are casting about for some more satisfactory substitute" (p. 1).

He quotes Professor Steinmann, of Freiburg, who says that "in scientific as in lay circles, there prevails a widespread feeling of uncertainty and doubt" (p. 4). He attributes this "to the fact that there is no agreement among men of science as to the manner in which evolution operates, or as to its efficient causes"' (p. 2).

Professor Scott writes, taking his book generally, as a Darwinian, and yet he says: "Personally, I have never been satisfied that Darwin's explanation is the rightful one; to one who approaches the problem from the study of fossils, the doctrine of natural selection does not appear to offer an adequate explanation of the observed facts" (p. 25).

"On the other hand," he says, "if Darwin's hypothesis be rejected, there is, it must frankly be admitted, no satisfactory alternative to take its place" (p. 26). He rejects the Mutation theory as insufficient (p. 24). 
After this we are not surprised to be told that "it is necessary to begin with a warning not to expect too much," and further that "the evidence for organic evolution must be indirect, since direct proof is unattainable" (p. 27).

Other admissions follow. Professor Scott says that "several distinguished naturalists altogether reject the recapitulation theory as a means of interpreting the facts of embryology" (p. 73) : he says also that "we should not close our eyes to the undeniable fact that it, like many another fruitful theory, has been pushed beyond its legitimate limits" (p. 61).

And towards the close of his book he says: "The pathway of science is strewn with the wrecks of hypotheses and theories, which have served their purpose and have been worn out and discarded" (p. 169).

We have seen on page 66 of this book what Professor Scott says as to Professor Nuttall's bloodtests. Then, as to the question of the inheritance of acquired characters, he tells us that "the same experiments are interpreted in diametrically opposite senses by different writers, according to their predisposition and general point of view" (p. 152).

When he comes to the evidence for evolution from Palæontology, he warns us again not to expect too much (p. 82), and he says that "the ancestry of mammals is still a question of much uncertainty" (p. 97).

Then as to the evidence from Geographical Distribution, he remarks: "Nobody would pretend for a moment that we understand all the phenomena of distribution, and can account for every seemingly anomalous fact, or that all difficulties have been removed" (p. 147). And as to the theory of evolution in general, he adds: "From the very nature of the - case, complete demonstration is impossible" (p. 168). 


\section{Special Creation or Evolution.}

Propissor Scotr says that there are only two alternative hypotheses to explain the character of the living world: -

"The first, called the doctrine of Special Creation, holds that each kind of animal and plant was created in its present form and is substantially immutable. This doctrine, formulated by Linnæus, was very widely adopted, and held the field until the publication of Darwin's book. 'The second is the hypothesis of Evolution, or "descent with modifications, according to which all animals and plants, as we know them, have been developed froin primordial germs, leaving open the question as to how life on the earth originated. If anyone declines to accept either of these hypotheses, it only remains to admit that the problem is a complete mystery, for which no solution has been found" (p. 29).

In discussing Geographical Distribution, Proiessor Scott speaks of the Oceanic Islands, which are either coral reefs or are "volcanic and have been built up from the sea-floor by the material ejected in the eruptions of submarine volcanoes," and he instances the Azores, Madeira, the Canaries, Cape Verdes, the Hawaiian Islands, and the islets of the South Pacific, all of which he considers, have never formed part of any Continent. Then he says: "The oceanic islands have peculiarly limited faunas; on the theory of special creation we should expect to find in them as large a variety of animals as their area, their vegetation, and their climate would enable them to support. On the theory of evolution they must have received only such plants and animals as could be carried to them by the wind, or currents of the sea, carried on driftwood or floating trees, or transported by birds" (p. 143).

What "we should expect to find" on the theory of 


\section{SPECIAL CREATION OR EVOHUTHON. 287}

Special Creation, is an argument used several times by Darwin in one form or another. Now we have 1 o information about the original creation of the animal world beyond the record in the first chapter of Genesis. We are not told whether the cartin was populated from one centre, or from a few centres, or from a multitude of centres. We are not told whether many species, like the human family, arose from a single pair. The facts we know as to the mid multiplication of life might make this possible for the sea-monsters, and the whole of the water formlation, to whom the seas of the world would be open : it might also be possible for the birds, or ior those which could cross the seas by flight. It inight also be possible in the case of land animals for a whole continent to be stocked by the progeny of a sirgle pair of each species. But as to all this, we are entirely without information, and have we ang right to found arguments upon what can only be guesses?

But what of the occanic islands of which Professor Scott speaks? Dr. Wailace says: "We have absolutely no exception whatever to the remarkable fact that all the oceanic islands of the globe are either of volcanic or coral formation; and there is, further, good reason to believe that those of this latter class in every case rest upon a volcanic fouvdation" (Darrinism, p. 342). But surely these islands have been thrown up by volcanic action long since the creation of animal life on the earth, and they must have been populated by some means from the nearest continent!

Indeed, this argument as to what we may suppose to have taken place at the creation of life upon this world, recoils upon the evolutionist, because he has to admit that, on his theory, there are many diffculties to be explained in regard to the means of the dispersal of animal life throughout the globe. 
When the Professor says that there are only two alternative hypotheses, Special Creation or Evolution, he omits all mention of the view advanced by the Rev. E. Wasmann, in his Modern Biology, that a certain number of species of plants and animals were originally created, and that others have been evolved from them. Does not this provide us with another alternative?

\section{Animals of Different Types.}

PROFESSOR SCOT'T mentions one objection made, which he admits to be a weighty one, that "comparative anatomy gives us no means of connecting animals of fundamentally different types or plans of structure." "Evolution within the type," he says, "might be admitted, without conceding the possibility of deriving one type from another"' (p. 55).

The answer proposed to this is, that if it were only possible for us to dig deep enough into the rocks of the earth's crust, we might possibly find the connecting links. This, however, is a supposition, without any basis of proof.

Is not Wasmann's suggestion a better one? It may be freely admitted that there has been evolution within the type, and yet the types may have. been originally distinct.

Professor MacBride says: "Darwin hesitated to assert that such different phyla as Arthropoda, Mollusca, and Vertebrata, are descendants of a common type of ancestor. He rather inclined to the belief that if life appeared on this globe by a process which we know nothing about, it may have appeared simultaneously in several different forms whose descendants remain as the different phyla to-day" (Zoology', p. 67).

Darwin really made several statements which it is not easy to reconcile exactly.

Towards the end of chapter xiii. of The Origin of 
Species he speaks of "all the species of a genus, though distributed to the most remote points of the world" being "descended from a single progenitor." And in the summary to this chapter he speaks of "all the individuals of the same species, wherever found," being descended from common parents. In the first volume of The Variation of Animals and Plants he says: "We may conclude that at least all the members of the same class have descended from a single ancestor" (p. 15). And in the second volume of the same work we read: "According to the belief now generally accepted by our best naturalists, all the members of the same order or class, for instance, the Medusæ or the Macrourous crustaceans, are descended from a common progenitor"' (p. 450). Apparently it is left open, whether the Darwinian theory of evolution asks us to believe in a common parentage for all the members of an order, or a class, or a genus, or only of a species. The difference between Darwin's theory and that of Wasmann seems to be not one of principle, but only of degree.

\section{Specific Centres of Life.}

SPHAKING of Mammals, Professor Scott says: "All the evidence at our disposal goes to show that every species originated in some one particular area and has spread from that starting point as far as circumstances would permit. This is called the 'doctrine of specific centres.' In the case of more comprehensive groups also, there is no reason to believe that among the higher animais, at least, the same genus, family, order, class, etc., ever arose twice independently in disconnected land areas" (p. 125).

What has been said on pages 256 to 259 of this book as to the views of different scientific writers on the Multiple Origin of Life, should be compared with what Professor Scott says as to "specific 
centres of life." The point is, do not these various opinions leave the question to a great extent open in regard to the argument for Evolution or for Special Creation?

Professor Rudolf Otto, in his Naturalism and Religion (p. 114), gives a brief summary of the views of Dr. Fleischmann, Professor of Zoology in Erlangen, who is a strong opponent of evolution, because, as Otto says, he keeps to matters of fact, and rejects speculations beyond these. "Modern zoology recognises not merely the four types of Cuvier, but seventeen different styles, phyla, or groups of forms, to derive one of which from another is hopeless. And what is true of the whole is true also of the sub-divisions within each phylum; e.g., within the vertebrate phylum with its fishes, amphibians, reptiles, birds, and mammals. No bridge leads from one to the other. This is proved particularly by the very instance which is the favourite illustration in support of the Theory of Descent-the fir of fishes and its relation to the five-fingered hand of vertebrates" (Die Descendztheorie, chap. ii.).

Professor Hamann, in his Entwicklungslehre und Darwinismus, as we have seen (p. 256), takes much the same line, contending that it is impossible to derive Metazoa from Protozoa in their present finished state of evolution. He also says that it is only by "a stretch of fancy that fishes can be derived from worms, or higher vertebrates from fishes" (quoted by Otto, p. 122).

Huxley, in Man's Place in Nature, speaks of the opinion of naturalists generally that there are five, or perhaps seven, "distinct plans or constructions in the whole of the animal world"' (p. 166).

\section{The Earliest Living Beings.}

UNDER the heading "Protozoa" (p. 253) something has been said to show the difficulties of the 
evolutionary theory in regard to the earliest organisms of which we have any knowledge.

One or two "Stations for Experimental Evolution" have been established, especially the one at Cold Spring Harbour, New York (p. 170), but we do not hear that they have reached any definite results. From the fact that there are some insects, etc., which have very short lives, and which produce offspring when they are only a few weeks old, it would seem that it might be practicable to arrange for observations extending over a much larger number of generations than would be possible with the higher animals. We have seen, however (p. 179), that Professor Kellogg, confirming what Sir J. W. Dawson said 40 years ago, declares that no undoubted cases of the formation of new species have ever been observed. Dr. Guenther says the same in Darnin and the Problems of Life (p. 360).

Evolutionists, however, have always a theory ready for every emergency. The opinion of Professor Zittel is that "periods of rapid and slow transformation often alternate in the evolution of a race" (Grundzüge der Paläontologie, 1903, pp. 14, $15)$, and it is suggested that we are at present living in a period of comparative fixity of organic forms (Wasmann's Modern Biology, p. 311).

On reviewing carefully all the evidence brought forward in support of evolution, we must see that there are limits beyond which there is nothing to show even its probability. The very earliest organisms are entirely hidden from us. Dr. Wallace thinks it "highly probable that the existing geological record only carries us back to somewhere about the middle of the whole period during which life has existed upon the earth" (The World of Life, p. 192).

Another fact is that fresh discoveries are from time to time pushing back the beginnings of life, 
and the beginnings of certain species of animals, to an earlier geologic period than any where they have formerly been known. Professor MacBride says: "Every few years fossils of some type of animal are discovered at an horizon far lower than the lowest at which they had been previously found to exist"' (Zcology, p. 64).

None of the recent handbooks which treat of evolution mention the uncertainties as to the contemporaneity of the geological strata shown by Huxley and by Sir Henry de la Beche (pp. 199, 201). Yet these uncertainties must, of course, largely affect the reliability of the evidence from Palaontology upon which so much depends. And the article Geology, in the Encyclopadia Britannica gives us also a warning as to the need of care in regard to drawing conclusions from the absence of fossils in sonie of the deposits, when it tells us of cases in which the same organisms, after being locally exterminated, returned again and again to the same area, and advises us to pause "before too confidently asserting that the highest bed in which we can detect certain fossils marks their final appearance in the history of life" (Vol. xi., p. 669).

\section{Huxley's Attitude.}

HuXI $\mathrm{E}^{\prime} S$ advocacy of evolution has probably, in this country at all events, done much to support the theory. But Professor E. B. Poulton says: "The attitude of Huxley towards Natural Selection was remarkable and unusual. Although no one strove so nobly, and against such odds, in its defence from unfair attacks, although no one ever fought the battle with more complete success, Huxley was at no time a convinced believer in the theory he protected" (Essays on Evolution, p. 193).

We must remember that what Huxley actually said was: "I adopt Mr. Darwin's hypothesis 
subject to the production of proof that physiological species may be produced by selective breeding" (Man's Place in Nature in Everyman's Library, p. 100). But such proof has never been produced.

In regard to the whole question we should also bear in mind, particularly in reference to some of the theories mentioned in these pages, what Huxley said about men of science generally: "Hen of science, like young colts in a fresh pasture, are apt to be exhilarated on being turned into a new field of inquiry, to go off at a hand gallop, in total disregard of hedges and ditches, to lose sight of the real limitation of their inquiries, and to forget the extreme imperfection of what is really known. Geologists have imagined that they could tell us what was going on at all parts of the earth's surface during a given epoch ; they have talked of this deposit being contemporaneous with that deposit, until, from our little local histories of the changes at limited spots of the earth's surface, they have constructed a universal history of the globe as full of wonders and portents as any other story of antiquity" (Man's Place in Nature, p. 175).

At a meeting of the Victoria Institute on 21 st June, 1915, after the reading of a paper by M. H. Edouard Naville, of the University of Geneva, on The Unity of Genesis, which dealt with the Higher Critical theories of German, English, and other Professors, Lord Halsbury, the President of the Institute, said: "I wish to make a general protest against the notion that a gentleman who calls himself a 'professor,' without any sufficient qualification, is thereby placed in a position of authority, and can make statements without a particle of evidence to prove them. I may be prejudiced in my view by my experience as a lawyer, but in court we are expected to give full proof in support of every assertion, and if we do not, it is naturally 
assumed that it is because we cannot do so. A 'professor,' on the other hand, appears to consider himself relieved from any such anxiety. He seems to think that all that he has to do is to say that such and such is the case, and as he is a professor he cannot be contradicted or brought to book. If anyone brings forward an argument on the other side, the 'professor' says that his opponent has made a mistake; but being a 'professor,' he does not consider himself obliged to' substantiate even this assertion" (Trans. Tictoria Institute, Vol. xlvii., p. 357).

This might apply, with equal justice, to some stateinents of Professors as to Eivolution.

My aim has been, in this volume, not se inuch to put forward any theory of my own, as to give in a succinct form all the facts and opinions that I have been able to gather from the most reliable works that have been published in recent years on the subject of Evolution. My readers must, as I have said, consider themselves a jury called upon to deliver a verdict on the evidence placed before them. Only let me.say, that to come to a right conclusion it will need a careful and painstaking consideration of all the facts bearing upon the various points at issue.

The real question before us is this-and there cannot be a more important one: Are we to accept absolutely what are put before us in so much of the current literature of the day as the assured conclusions of science, interpreting the Bible to fit in with those conclusions, or believing as much of it as will not contradict them? Or are we to believe implicitly the plain statements of Scripture as to the origin of mankind and of the world in which God has placed us, resting in the certainty that while now we can only read the Book of Nature very imperfectly, it will never, when we can understand it aright, be found to contradict God's greater Book of Revelation? 


\section{The Testimony of Science to Scripture.}

\section{The Two Books.}

Gon has given to us two books: the Book of Nature, and the Book of Revelation. We read of them both in the 19th Psalm :-

"The Heavens declare the glory of Crod."

"The Law of the Lord is perfect, converting the soul."

As both these books come from God they cannot possibly contradict one another.

But our human interpretations of these books are fallible: we must admit that mistakes have been made in the past in the interpretation of Scripture, and surely scientific men must equally admit that mistakes have been made in their interpretations of Nature.

Messrs. Dewar and Finn say in The Making of Species: "Men of science not infrequently charge the clergy with adhering to dogma in face of opposing facts; it seems to us that many of the apostles of science are in this respect worse offenders than the most orthodox of Churchmen" (p. 378).

Perhaps, if some misinterpretations and some misconceptions can be cleared away, it mav be possible to see that not only do the facts brought to light by Modern Science, as distinguished from the theories, not contradict Scripture, but that, on the contrary, they afford on many important subjects very reniarkable confirmation of Scripture.

We have to deal on the one hand with misinterpretations by those who attack the Bible, and on the other hand with mistaken theories sometimes put forward by earnest defenders of the Bible. 


\section{THe Creation Narrative.}

Many writers have strongly criticised the Creation narrative in Genesis, and declared it to be at variance with the facts established by Science.

It is, of course, impossible in a short space to discuss fully any of the points connected with the subject, but there are some considerations which may be mentioned.

The great majority of our evangelical commentators consider the "Days" of Creation to be periods of immense length, extending over the geological ages.

They could hardly be sun-measured days, in view of the fact that the sun and moon are not mentioned until the fourth day.

They were not man's days, for man did not arrive until the sixth day : they must be God's days.

It mar be noticed that in the first two chapters of Genesis the word " day" is really used in five different sen ies.

The suggestion may be made that, as regards the characteristic work of each day, the days follow in chronological order, but that, as regards some things that are related, the record may overlap the day following (this is Mr. Gladstone's view in The Impregnable Rock of Holy Scripture), and also, in some cases, it may orerlap the preceding day. The record of each day may thus gather round itself all that belongs, before and after, to the characteristic work of the "Day." This answers a serious objection made by Canon Driver as to the sun (Genesis, p. 25).

As regards what is known as the "second Creation narrative" (Genesis ii. 4-25), perhaps a new light will come upon it if we consider it as Adam's own autobiography, recorded from his own point of view (though, of course, under Divine inspira- 
tion), and dealing simpiy with that part of the world with which he was first acquainted.

The chronological question has been dealt with on pages 125 to 127 of this bonk. We have seen that it is impossible to challenge the accuracy of the Bible history on the basis of figures which have come down to us from four different sources, neither agreeing fully with either of the others, and showing clear marks of having been intentionally altered in one way or another: we have seen also that there is every reason to believe that there are many omissions in the list of the patriarchs from Noah to Abraham, and that the names given are probably only those of the most prominent men.

\section{THE FLOOD.}

Canon Driver, in his Genesis (pp. 99-101), attacks the Bible narrative of the Flood, and declares that it cannot be historically true. For this view he assumes that "the earth" in the narrative must mean the whole earth as we know it to-day, and that " the mountains" must mean all the mountains in the world.

'Then he assumes that "all species of living terrestrial animals, including many peculiar to distant continents and islands, and others adapted only to subsist in the torrid or frigid zone," must have been brought by miraculous means into the ark to fulfil the terms of the narrative. Then he contends that the theory of a partial deluge will not avail, because long before 2501 B.C. mankind had spread as far as Egypt and established a civilisation there which could not have been affected by a flood, however extensive, in Babylonia; also that such a flood would not have destroyed all the animals upon the earth.

There are very simple answers to these objections. 
We do not at all know the date of the Flood: it may well have been several thousand years earlier.

Neither do we know the extent of the Flood. The object was the destruction of the whole human race, except the eight who took refuge in the Ark, and we do not know how far, at that time, mankind had spread.

When the writer speaks of the "earth" he means the earth as he knew it, and the "mountains" were all the mountains of which he had any knowledge. The Hebrew word for " earth," which is used in the account, is in more than a thousand other passages in the O1d Testament translated simply "land."

The narrative certainly does not require us to believe that all the animals in the world were destroyed. If so, why not the fishes?

It is only the Noah's Arks of our childhood that. have fostered the idea of there having been lions and tigers in the Ark; all that the narrative requires is that there were representatives of those animals that were common to the region where the waters extended.

As to the "mountains of Ararat," on which the Ark rested, the identification of the place is wholly uncertain. The Encyclopicedia Britannica (article A rarat) tells us that the name "Ararat" is given in Assyrian inscriptions to a kingdom that at one time included the greater part of the later Armenia, and that the name was in later times transferred to what is now known as Mount Ararat, because it was supposed that the Ark rested there. We must remember that two distinct canses are assigned in Genesis for the Flood: "The same day were all the fountains of the great deep broken up, and the windows of heaven were opened." The first cause may to some extent have changed the face of the land. 


\section{THE CREATION DAYS.}

\section{Untenable Theories.}

We must now mention some questions in regard to which theories, which we think untenable, have been put forward by writers who are earnest defenders of the full inspiration of God's Word.

\section{THE IITERAL-DAy THEORY.}

It was, of course, at one time generally believed that the days of Creation were literal days of twentyfour hours, like our own days. There are some modern writers who still hold this view.

They accept the figures in the Hebrew Bible as a means of ascertaining the date of the Creation, and thus make it 4004 B.C., according to Archbishop Usher's chronology. They necessarily hold that all the ages of geology are to be placed before that date, and they are, of course, compelled by this theory to consider that all existing animal and plant life upon the earth had its origin less than 6000 years ago.

Agassiz, who died in 1873, was a well-known man of science who supported this view. He was a consistent opponent of evolution.

The eminent Christian geologist, Professor J. D. Dana (who died in 1895), maintained, on the other hand, that not a single fact in geology has ever been brought forward to support the idea of a re-arrangement of the earth just before man appeared (quoted by Sir J. W. Dawson, in The Origin of the World, p. 146).

The Chaos-Intervat, Theory.

Several writers on the first chapter of Genesis translate the second verse, "The earth became waste and empty," and upon a passage in Isaiah of 
doubtful interpretation (Isaiah xlv. 18), and one or trio other passages in the prophetical books, they base the theory that there was an interval of chaos following the work of Creation recorded in the first verse, and they hold that the six days of the Creation week came after this chaos-interval.

The expositors who take the Literal-day view of the Creation week adopt this theory of an interval of chaos and disorder immediately preceding it, and they represent the work of the six days as only a work of the "rehabilitation" of the earth after the chaos-period. This means, practically, that the six days' work of which we read in the first chapter of Genesis was a second creation. Surely, this is contrary to the whole teaching of the Bible! There are about forty passages of Scripture which refer to the Creation of the world, and it is always treated as ONE Creation.

The fourth Commmandment is sometimes appealed to in support of the Literal-day theory, but in Exodus xx. 11 it is certainly not a "rehabilitation" of the earth, and that alone, after a period of chaos, of which we read, when we are told that " in six days the Lord made heaven and earth, the sea, and all that in them is."

The idea of a chaos interval is certainly mentioned with approval by some expositors also who treat the "Days" as long periods of time, but none of them explain their view clearly. Apparently they must suppose it to have come before the formation of the earliest geological strata. As to what happened in the very earliest times of the world's existence Science does not profess to be able to tell us anything, but the objection that forty passages of Scripture refer manifestly to ONE creation applies to every form of the chaos-interval theory. 
Pre-Adamite Man.

Another view hazarded by some earnest defenders of Inspiration, as to the existence of a pre-Adamite race of men, has been dealt with on pages 155 to 158 and shown to be contrary to the general tenor of Scripture.

\section{Scripture confirmed by Science.}

INE must now turn to the other side of the subject, and remark some important confirmations of the Bible by the Science of the present day.

\section{In THE Beginning.}

Science certainly shows us that there was a beginning to life on our globe-a beginning to the earth itself-a beginning also to the whole solar systein.

Sir J. W. Dawson says: "If we cannot say that all things have existed from Eternity, how did they begin? Science forbids us to say that it was by mere chance, for order and system cannot come of chance." What then could be more appropriate than for a Divine revelation to open with "In the Beginning "?

\section{"IN THE BEGINNING GOD."}

We have seen that Dr. Alfred Russel Wallace, in The World of Life, in reviewing the history of anima! and vegetable life during the geological ages, contends that a plan and purpose are traceable throughout-an organising, directing life principle-and he says that "we are forced to the assumption of an infinite God by the fact that our earth has dereloped life, and mind, and ourselves" (p. 393). 


\section{THE Unity OF God.}

The ancient religions of the world, like heathendom to-day, had a multitude of gods, and the creation myths handed down to us attribute the origin of the world to the activities of several of these deities, or, as in the Babylonian Epic, make it the result of a conflict between them.

How did the Hebrew nation know better unless they were divinely taught? The religion of the Bible is the only ancient religion that reveals to is God, the Creator of the Universe, as ONE. Modern Science, which tells us that the same natural laws which operate upon our own earth govern the constitution and the movements of the most distant stars, demonstrates the fact that the World of Nature is ONE. And it has always been so. Sir J. W. Dawson says: "In all the lapse of geological time there has been an absolute uniformity of Natural Law." Thus, according to Science, Nature displays a unity which is quite in accord with the teaching of the Bible that it is the work of ONE Almighty Creator. And on a broad survey of this World of Nature we have Dr. Wallace, a distinguished man of science and an evolutionist, telling us that it demands for its explanation the ONE infinite Crod.

\section{The Second Verse of Genesis.}

"Without form and void." "Waste and void" (R.V.), "Waste and wild" (Rotherham), "Unsightly and unfurnished" (Sept.): this description of the first phase of the earth's existence is quite confirmed by Geology.

\section{LIGHT BEFORE THE SUN.}

This was once a great Scripture difficulty, but Modem Science has completely turned the tables, 
and it is surely now one of the most remarkable proofs of the Divine origin of the Creation Story in Genesis.

The ancients naturally looked upon the sun as the most prominent and powerful agent in the kingdom of Nature, and, as the bringer of light, and warmth, and life to mankind, it was an object of worship in many lands, especially those adjacent to Palestine. When we remember this, is it not absolutely unthinkable that any human writer in early times could have given an account of the origin of the world, and have put light before the sun, and independent of it?

What does Science now tell us? In The Astronomy of the Bible, Mr. E. W. Maunder, F.R.A.S., of Greenwich Observatory, says: "We know that our sun is not the only source of light, since it is but one out of millions of stars, many of which greatly exceed it in splendour. Further, most astronomers consider that our solar system existed as a luminous nebula long ages before the sun was formed as a central condensation" (p. 69). Professor Arnold Guyot says: "During the age of matter, the intensity of chemical action was a source of permanent light-the earth was self-luminous" (Creation, p. 92). Professor J. D. Dana, editor of the American Joumal of Science, says that "light, like heat and elcctricity, is nothing else than a mode of motion" (Bibliotheca Sacra, April, 1885). And Dr. G. F. Wright speaks of the time when "the earth's swaddling-band of clouds was all one blaze of electric light" (Scientific Confirmations of Old Testameint History, p. 379).

We must notice that Genesis does not say that light was created. It was called forth by the Divine fiat: "Let there be light, and there was light." We may see the appropriateness of this 
when we understand that light is not dependent on the presence of a luminous body, but results from a vibration of the ether diffused through interplanetary space.

\section{THE StarRy HOST.}

God said to Abraham: "I will multiply thy seed as the stars of the heaven, and as the sand which is upon the sea shore" (Gen. xxii. 17) ; and in Jeremiah we read: "As the host of heaven cannot be numbered, neither the sand of the sea measured: so will I multiply the seed of David My servant" (Jer. xxxiii. 22). In each case the promise was that the seed should be inmumerable.

As Dr. Pierson says: "There must have seemed to Abraham a great difference between the number of the stars, and the number of the atoms of dust, yet they are alike countless." Hipparchus, about 150 B.C., and Ptolemy, about 139 A.D., made catalogues of the stars, giving about 3,000 in the entire Southern and Northern celestial hemispheres. But Sir Robert Ball says: "To tell the number of the stars is a task which no man has accomplished.

Our great telescopes can probably show at least fifty millions of stars" (The Story of the Heavens, p. 25). Here we see that modern science shows how appropriate was the language of this ancicnt promise.

\section{The Sedimentary Rocks.}

"There were heavens from of old," said St. Peter, "and an earth compacted out of water and amidst water" (2 Petor iii. 5, R.V.), and in Psalm xxiv. 2, we read: "He hath founded it upon the seas, and established it upon the floods."

What can be a better description than this of the sedimentary rocks, wbich form so large a propor- 
tion of the earth's crust, laid down in an orderly way by the action of water?

\section{The ORDER OF Creatron.}

Undoubtedly Geology confirms the general order of the appearance of living beings upon the earth as given in Genesis :-

The water population:

The air population:

The land population :

Man.

A very striking testimony to the Mosaic account of the Creation is given by that uncompromising opponent of the Christian view of the world, Professor Ernst Haeckel, the leader of the materialistic school in Germany, in his History of Creation (pages 37, 38, Eng. trans.) :-

"The Mosaic bistory of creation, since, in the first chapter of Genesis, it forms the introduction to the Old Testament, has enjoyed, down to the present day, general recognition in the whole Jewish and Christian world of civilisation. Its extraordinary success is explained, not only by its close connection with Jewish and Christian doctrines, but also by the simple and natural chain of ideas which runs through it, and which contrasts favourably with the confused mythology of creation current among most of the other ancient nations. First, the Lord Grod creates the earth as an inorganic body; then he separates light from darkness, then water from the dry land. Now the earth has become inhabitable for organisms, and plants are first created, animals later; and among the latter the inhabitants of the water and of the air first, afterwards the inhabitants of the dry land. Finally Grod creates man, the last of all organisms, in his onn image, and as the ruler of the earth. 
"Two great and fundamental ideas, common also to the non-miraculous theory of development, meet us in the Mosaic hypothesis of creation with surprising clearness and simplicity-the idea of separation or differentiation, and the idea of progressive development or perfecting. Although Moses looks upon the result of the great laws of organic development (which we shall later point out as the necessary conclusions of the doctrine of descent) as the direct actions of a constructing Creator, yet in his theory there lies hidden the ruling idea of a progressive development and a differentiation of the originally simple matter. We can therefore bestow our just and sincere admiration on the Jewish law-giver's grand insight into nature, and his simple and natural hypothesis of creation, without discovering in it a so-called Divine revelation."

\section{The Unity of Mankind.}

While the Bible reveals to us the one God, it teaches us also the unity of mankind. Science has long hesitated to confirm this truth, but now we read in the article Anthropology, in the Encyclopadia Britannica: "On the whole, it may be asserted that the doctrine of the unity of mankind stands on a frmer basis than in previous ages." And in speaking of the mental unity of mankind it says: "The measure of this unity is, that any child of any race cau be brought up to speak the language of any other race."

Huxley, writing in 1863 on Darwin's Origin of Species, said: "I am one of those who believe that, at present, there is no evidence for saying that mankind sprang originally from more than a single pair ; I must say, that I cannot see any good ground whatever, nor even any tenable sort of evidence, for believing that there is more than one species of 
Han" (Man's Place in Nature, p. 233). And, indeed, when we consider it, the evolutionist must hold this, for if man had arisen from the animal world, under varying conditions, at a dozen different points of the world, at a dozen different times, the doctrine of Natural Selection would demand that there should be a dozen different kinds of men, all differing from one another in bodily structure. As Darwin says, in The Descent of Man: "If the races of man had descended, as is supposed by some naturalists, from two or more species which differed from each other as much, or nearly as much, as does the orang from the gorilla, it can hardly be doubted that marked differences in the structure of certain bones wotld still be discoverable in man as he now exists" (p. 276). Huxley also refers to " the overwhelming evidence in favour of the unity of the origin of mankind afforded by anatomical considerations" (Lectures and Lay Sermons, p. 98).

\section{THE SABBATH.}

The necessity to man of a stated period of rest from labour, and the beneficence of God's provision of one day in seven, are fully borne out by the experience of ages, and by the cunclusions of Modern Science.

In September, 1915, the Minister of Munitions appointed a Committee "To consider and advise on questions of industrial fatigue, hours of labour, and other matters affecting the physical health and physical efficiency of workers in munition factories and workshops," and in their report in November, 1915, which was issued as a Parliamentary Paper, they said: "The evidence before the Committee has led them strongly to hold that if the maximum output is to be secured and maintained for any length 
of time, a weekly period of rest must be allowed. Except for quite short periods, continuous work, in their view, is a profound mistake and does not pay-output is not increased. On economic and social grounds alike this weekly period of rest is best provided on Sunday, and the Committee are strongly of opinion that Sunday work should be confined to sudden emergencies, etc."

They added: "The Committee consider that the discontinuance of Sunday labour should be of universal application, and should extend to all classes of workers, except that where the work must necessarily be continuous special arrangements will be necessary. . . The Committee trust that it will at least be practicable to lay down the principle that Sunday labour is a serious evil which should be steadily and systematically discouraged and restricted."

Another Parliamentary Paper (Cd. 8335) contains a report by Dr. A. F. Stanley Kent, dated August 16 th, 1916, on an investigation of Industrial Fatigue by Physiological Methods, which says:

"It will be recognised that a progressive diminution of the power of the worker to resist fatigue, or to recover from it, if present, affords a strong argirment against the practice sometimes adopted of employing Sunday labour. For in normal times the lessened efficiency found towards the end of the week is remedied by the rest obtained on Saturday afternoon and Sunday, but where Sunday labour is introduced, the rest is inadequate, and the condition of fatigue becomes permanent.'

Surely nothing could show more decisively that science and experience combine to prove that God's provision of one day's rest in seven, instituted at man's entry into the world, is an absolute necessity for mankind. 


\section{EVIL BEFORE THE FALI.}

That pain and death were in the world for untold ages before the Fall is sometimes spoken of as a difficulty : it is rather a confirmation of Scripture. In Eden were placed the tree of the knowledge of good and evil, so there was already evil in the world. That Satan, who, we know, is " the Prince of this world" (John xii. 31 ; xiv. 30 ; xvi. 11), was able to take the subtle form and character of the serpent, and use it as his tool and mouthpiece, must surely show that at some time he had obtained some mysterious power over the brute creation. That he could hide his own personality so effectually that it is the serpent alone that appears as the agent of evil in the narrative is a confirmation of what St. Paul tells us (2 Cor. xi. 14) as to the power of the Evil One to transform himself even into an "angel of light."

If we ask, "When did evil first enter this worlu?" we can only answer that "it is the glory of God to conceal a thing" (Prov. xxv. 2), and this surely is one of the things He has concealed from us.

\section{The Deluge.}

That a destructive flood once visited the earth cannot be denied. M. F. Lenormant, Professor of Archrology at the Bibliothéque Nationale of Paris, wrote in Les Origines de l'Histoire d'après la Bîble: "We are in a position to affirm that the account of the Deluge is a universal tradition in all branches of the human family, with the sole exception of the black races, and a tradition everywhere so exact and so concordant cannot possibly be referred to as an imaginary myth. . . . It must necessarily be the reminiscence of an actual and terrible event." Of course there have been many great inunda- 
tions in the history of the world; possibly even some that may have extended over a wider extent of country than the Flood of Noah : but that was the only one that involved the destruction of all mankind. Some writers, in endeavouring to establish the truth of the Bible narrative, have appealed to the evidence of inundations in some countries that were probably not affected at all by Noah's Flood, which very possibly did not extend beyond the plains of Mesopotamia.

\section{SCRIPTURE ACCURACY.}

Several other remarkable instances of the way in which modern science has shown the accuracy of the language used in the ancient Scriptures are given by Dr. Pierson in his excellent books, Many Infallible Proofs, and God's Living Oracles.

The Immensity of Space: Jer. xxxi. 37; Psalm ciii. 11.

The Reign of Law throughout creation: "The rain obeys a decree, and the thunder and lightning move obedient to law-the sea can go but so far, and the wind returns according to his circuits" (Job xxviii. 26 ; Job xxxviii. 11, 25 ; Eccles. i. 6 ; Isaiah $\mathrm{xl} .12$ ). The relation established between land and sea: Job xxxviii. 8-10; Jer. v. 22.

"He hangeth the earth upon nothing" (Job xxvi. 7).

There are other striking examples in Dr. Pierson's two books.

THE JEWS.

The Bible is full of prophecies of the restoration of God's ancient people of Israel to their own land. Nearly all the nations of antiquity have passed away, and can no longer be identified, but the Jews, though scattered throughout the world, remain a distinct people, bound together by their history and their traditions, by the Oracles of God of which 
they were the appointed guardians, and by the Hebrew language and literature. This marvellous preservation of the identity of the Jewish race, notwithstanding their wide dispersion, has for ages been a testiniony to the world as showing the possibility of the fulfilment of God's promises to them as a nation.

But to-day we have the truly reinarkable facts, first of a British Army in Palestine, and in the occupation of Jerusalem, and then of a declaration of the British Government in favour of the restoration of the people to their own land. Surely, we cannot help seeing in these things not only a striking proof of the truth of God's Word, but also significant intimations of the near fulfilment of those prophecies concerning the Second Advent of our Lord which are so closely connected with the future of the Jews.

\section{ThE Bibi,e.}

The Bible, as we possess it to-day, is really the best witness to itself.

If we survey the history of the Church throughout the Christian centuries, is it not a record of divisions, of controversies, of heresies, often of fierce struggles and persecutions? Is it not a narrative of separations of church from church, of sect from sect, of the foundation of many new churches on the ground of difference of doctrine and practice? How comes it, then, that there are not as many different Bibles as there are churches? For the Old Testament canon, as preserved by the Jewish Church, we have the seal of our Lord's authority. But what as to the canon of the New Testament? By whatever means it was brought about, the marvellous fact that all Christian Churches, notwithstanding their many divisions, accept one New Testament and one Bible, is most certainly due to the over-ruling providence of God. 
Does any reader question whether these considerations come under the heading of the testimony of Science?

There is one writer who well says: "There are no scientific facts. All facts are equal before Science. It is the classification and interpretation of facts that concerns science. The greater the number of facts that are surveyed, the completer the classification, and the more correct the interpretations."

\section{EAST AND WEST.}

This book shall conclude with an article contributed by the present writer, in June, 1884, to Our Own Magazine, a paper for young people, which he has now edited for thirty-eight years :-

\section{Divid's Gegraphy.}

Did it ever strike you why David should not have said, in the 103rd Psalm, "As far as the north is from the south," instead of "As far as the east is from the west"?

Any schoolboy can find upon the globe the north pole and the south pole, and can tell that the distance from one to the other is about 12,428 miles. It is a distance that can be measured. But who can tell how far the east is from the west? You may travel westward, and go round the world as often as you like, but you will never reach the west; and you may go the othir way, but you will never reach the east. The distance between them is a distance that cannot be measured.

But did David know anything about the north pole and the south pole? Why, centuries after his time, the most learned of the Greeks did not know that the earth was a round ball, and they made all sorts of absurd guesses as to its shape. Many thought that it was flat, like a plate; Anaximander taught that it was a cylinder; Leucippus said that 
it was like a drum; and Heraclides that it was like a boat. And the learned men of David's day could certainly not have brought him, by their geographical knowledge, any nearer to the truth.

Surely here is a proof that the Bible is accurate in regard to the facts of science! David could not know which was farthest-the north from the south, or the east from the west, but God's Holy Spirit taught him to use the expression that was exactly right. Now we know more about geography, we can see that "as far as the east is from the west " is the only expression that David could have used to give the idea intended-a distance that is immeasurable.

What beautiful comparisons we have in these two or three verses! God's mercy so great-high as the heavens from the earth; our sins put so far away-far as east from west! As if Crod should say: "Look up to heaven, and see if you can measure how high it is : that is the measure of $\mathrm{My}$ mercy." Or as if He should say : "Take a ship, and sail round the world towards the setting sun, till you find how far off the west is, or travel towards the rising sun till you find how far off the east is ; then you shall know how far your sins have been removed, if you are trusting in the precious blood of Jesus."

"So far," we can write against verse 12 , but opposite verse 13 we should write, "so near" ; for we see that God is our Father-our reconciled Father in Christ, and we are His dear, dear children!

What a blessing to have our sins so far off; and to have our loving heavenly Father so near! 


\section{APPENDIXI.}

\section{What Science does not know.}

A very important thing to remember in considering the theory of Evolution is the ignorance which scientific men are obliged to confess in regard to a large number of subjects. If the facts were known on these subjects, it might, surely, in many cases, affect the theories that have been so confidently built up by many scientific writers. We take from The Origin of Species a number of extracts showing instances in which Darwin had to admit our ignorance on many important points. The pages referred to are those in the popular shilling edition of the look.

CHAP. I.- "The laws governing inheritance are for the most part unknown" (p. 10).

"The origin of most of our domestic animals will probably for ever remain vague" (p. 13).

CHAP. II.--"'The causes which check the natural tendency of each species to increase are most obscure. Nor will this surprise anyone who reflects how ignorant we are on this head even in regard to mankind" (p. 49).

On the struigle for existence he says: "So profound is our ignorance, and so high our presumption, that we marvel when we hear of the extinction of an organic being" (p. 53).

CHAP. IV.- "The curious and not well understood cases of parthenogenesis" (p. 70).

"Naturalists have not defined to each other's satisfaction what is meant by an advance in organisation... We shall see how obscure the subject is, if we look, for instance, to fishes" (p. 91).

As to first steps in advancement at the first dawn of life: "As we have no facts to guide us, speculation on the subject is almost useless" (p. 93).

"If we make due allowance for our profound ignorance 
on the mutual relation of the inhabitants of the world at the present time, and still more so during past ages" (p. 94).

CHaP. V.-Correlated Variation: "This is a very important subject, most imperfectly understood, and no doubt wholly different classes of facts may be inere easily confounded together" (p. 106),

"Our ignorance of the laws of variation is profound. Not in one case out of a hundred can we pretend to assign any reason why this or that part has varied" (p. 122).

CriAP. VI.- "We are much too ignorant in regard to the whole economy of any one organic being, to say what slight modifications would be of importance or not" (p. 147).

"We are profoundly ignorant of the cause of each slight variation or individual difference" (p. 148).

CHAP. VII.- "Many mysterious cases of correlation, which we do not in the least understand" (p. 159).

"We are ignorant with respect to the conditions which determine the number and range of each species" (p. 167).

"As we do not know the full history of any one group of beings, it is as useless to ask, as it is hopeless to attempt answering, such questions" (p. 183).

CHAP. IX.- "Considering how scanty our knowledge is in regard to hybrid animals" (p. 225).

"No explanation can be given of these facts" (p. 232).

"It must, however, be owned that we cannot understand, on the above or any other view, several facts with respect to the fertility of hybrids" ( $p .235$ ).

"I will not enlarge on this obscure subject" (crosses between hybrid plants): (p. 239).

"Seeing how profoundly ignorant we are in regard to the normal and abnormal action of the reproductive systein" (in animals generally): (p. 240).

"We are as ignorant of the precise cause of the sterility of first crosses and of hybrids as we are why animals and plants removed from their natural conditions become sterile" (p. 247). 
CHAP. XI.- "If we ask ourselves why this or that species is rare, we answer that something is unfavourable in its conditions of life, but what that something is we can hardly ever tell" (p. 276).

"If we mnst marvel, let it be at our own presumption in imagining for a moment that we understand the many complex contingencies on which the existence of each species depends" (p. 279).

CH.AP. XII. - "Considering our ignorance with respect to -former dimatical and geographical changes, and to the various occasional means of transport" (p. 302).

"As far as anything can be inferred from these scanty facts" (as to transport of seeds to islands): (p. 305).

CHap. XV.-." It cannot be denied that we are as yet very ignorant as to the fuli extent of the various climatal and geographical changes which have affected the earth during modern periods" (p. 382).

"l'be more important objections (to the Natural Selection theory) rclate to questions on which we are confessedly ignorant; nor do we know how ignorant we are" (p. 385).

From The Descent of Man :-

"We must not, however, be too confident in deciding what modifications are of service to each being; we should remember how little we know about the use of many parts, or what changes in the blood or tissues may serve to fit an organism for a new climate or new kinds of food" (p. 91). Fron The Variation of Animals and plants under Domestication :-

"In almost all experiments on the crossing of animals there are so many causes of doubt, that it is extremely difficult to conve to any positive conclusion" (Vol. I. p. 39).

"We are profoundly ignorant of the cause of each sudden and apparently spontaneons rariation, as well as of the infinitely numerous shades of difference between the birds of the same family" (Vol. I. p. 259).

"If we ask ourselves why this or that character has been modified under domestication, we are, in most cases, lost in utter darkness" (Vol. II. p. 321).

Let us see what some other writers say on the snbject:Professor H. Reinheimer says:-." Abont the nature of 
the most universal forces in the universe, those termed cohesion and afinity, for instance, we remain totally ignorant" (Nutrition and Evolution, p. 2).

Professor J. A. Thomson:- "In regard to the causes of variation it is too soon to speak except in tentative whispers. What Darwin said must still be said: Our ignorance of the laws of vatiation is profonnd. Not in one case out of a hundred can we pretend to seeing any reason why this part or that part has varied" (Heredity, p. 100).

"In regard to the origins of domesticated animals and cultivated plants, we remain in great obscurity. In regard to the actual pedigree of wild species we are in still greater ignorance" (Heredity, p. 137).

Professor E. B. Poulton:- "We want to know why. That is all. Whither the knowledge we are accumulating is tending no one can tell. One of the greatest men of all time has said that we are like children picking ap shells on the shore of the ocean" (Essays on Evolution, Intro. p. 47).

"Even now we are just as much in the dark as to what gravitation itself is as when Newton wrote" (Essays on Evolution, p. 97).

Dr. Archibald Reid:- "The lowest organisms are probably quite beyond our ken. Higher organisms than these appear as minute and apparently formless specks, the protogenes of Haeckel, visible only under the highest powers of the microscope, and composed of that transparent jelly, 'the formal basis of all life,' which is known as protoplasm. About them also we have as yet been able to learn but little beyond the fact that they are living beings" (Evolution of Man, p. 31).

Professor V. H. Kellogg: "I do not know. Nor in the present state of our knowledge does anyone know, nor will anyone know until, as $\mathrm{W}$. K. Brooks says of another problenn, we find ont. We are ignorant; terribly, immensely ignorant. And our work is to learn. To observe, to experiment, to tabulate, to induce, to deduce. Biology was never a clearer or more inviting field for fascinating, joyful, hopeful work. To question life by new 
methods, from new angles, on closer terms, under more precise conditions of control; this is the requirement and the opportunity of the biologist of to-day" (Darvinism To-day, p. 387).

M. Henri Bergson:- "The question of the physical framework of the protoplasm is not yet settled. We are still further from compounding protoplasm chemically" (Creative Evolution, p. 37).

Dr. C. Guenther :- "Ihe similarity of organisms is a hopeless puzzle. It is unintelligible why some animals so closely resemble others in structure, others still more, and others not at all" (Darwin and the Problems of Life, p. 155).

"We have as yet made so little progress in the studying the nature of the body. We must therefore modestly admit that our knowledge is not sufficient to explain. the rudimentary organs" (ibid. p. 169).

"We must draw a profout distinction between living and dead albunen. 'This has indeed induced many' scientists to discard the name, living albumen, and replace it by the term biogen. We know very little of the composition of these biogens" (ibid. p. 232).

"We must not at once throw the blame on the theory of selection when we camnot find the solution, but must remember the imperfect condition of our knowledge. We cannot determine the origin of an organ with certainty. as ne have no absolutely certain documents" (ibid. p. 243).

"We must admit the impotence of science in the face of these embryonic mysteries" (ibid. p. 295).

"We do not know under what conditions the chief elements of the organic body, the albuminoids, are produced. Living albument is still an unsolved problem to us. Hence our knowledge of the living substance is as yet much too scanty for us to construct successfully a mechanical explanation of the vital processes" (ibici: p. 351).

"Even when we abaudon the attempt to grasp the whole universe, and turn to a small part of it, we encounter insuperable difficulties. Every part of the world, no matter how small, has so many differences latent in it that they cannot be counted" (ibid. p. 377). 
"It is possible that new observations might be made that would compel science to re-arrange all its laws However that may be, physical science is not absolute and unconditional, because it supposes that what is true in a thousand cases will not prove untrue in the next one" (ibid. p. 397).

Professor A. Weismann :- "Thole regions of phenomena are still sealed to us, and I consider it probable that the nervous system in particular is not yet exhaustively known to us" (The Evolutionary Theory, Vol. II. p. 64).

"There is still a great deal that is doubtful in our theories as to the transformations of organisms, and much remains to be done" (ibid. p. 343).

Speaking on mutual sterility :--"But no certain conclusion can be based upon either of these arguments-not upon the theoretical one, because here again we are nuable to estimate the extent of this loss; and not upon the argument from fact, because the results of experiments in crossing in animals have generally been orerestimated" (ibid. p. 349).

"But let us leave these imaginings, and wait to see whether the chemists will not possibly be able to furnish us with a starting point for a more concrete picture of the first origin of life. In the meantime we must confess that we find ourselves confronted with deep darkness" (ibid. p. 371).

"Let us now leave our parable and enquire what paths the organic world has actually taken in its transformations, in what succession the individual forms of life have evolved from one another; in short, how the actual genealogical tree of this earth's animate population is really constructed in detail. To this I can only reply that we have many well-grounded suppositions, but only real cer= tainty in regard to isolated cases. . . In regard to the genealogical tree of organismis as a whole, we can only make guesses, many of which are probable, but are never quite certain. The palæontological records which the earth's crust has preserved for us for all the ages are much too incomplete to admit of any certainis" (ibid. p. 3s8). 


\section{A PPENDIX II.}

In consequence of the importance of the particulars noted on parges 45 to 49 of the first discovery of the sheletons at Spy, in Belginm, the original French of the report is bere given from L'Homme Contemporain du Mammoutin d Spy :-

\section{Cranes ct ossements humains.}

Page 25.-- Cn prenier squeleite, assez inconplet malheureasement, a été trouvé à six mètres au sud de l'entrée de la grotte; un autre, également fort incomplet, à huit mètres au sud du même point et un peu à l'onest du premier.

La position du prenier squelette que nous désignerons sous le nom de "Spy No. 2," était difficile à préciser. I,es as se trouvaient déplacés de leurs connexious naturelles et le crâne était fracturé en une quarantaine de morceaux.

Te second squelette que nous appellerons "Spy No. 1," paraissait couché sur le coté droit, la main appuyée contre la mâchoire inférieure.

Il était placé à peu près en travers de l'axe de la grotte, la tête vers l'est, les pieds yers l'ouest. Beaucoup d'os n'ont pas été retrouvés malgré des recherches minutieuses. Le crâne était fracturé. Plusieurs fractures étaient fort anciennes, des morceaux déplacés de leurs connexions anatomiques étant resoudés par des incrustations calcaires.

Nous arous ru que des blocs calcaires de plusieurs mètres cubes de volume sont tombés sur la terrasse. La désagrégation des squelettes est due vraisemblablement à ces éboulis. L'étude des fractures des os confirme cette manière de voir. Lorsque nous avons recueilli la mâchoire inférieure du "Spy No. 1," celle-ci était brisée suivant la sy̆mphyse, une phalange de la maiu était engagée au milieu de la. fracture, et le tout était resoudé par un tuf argileux.

ANNEXE.-Malgré toutes les précautions, un huméras humain a été brisé, lorsqu'on a essayé de l'extraire de l'argile et des pierres où il était fortement encastré. 
From pages $625-7,631,652,656$ :-

Los os jugaux n'existent ell partie que sur le crâne No. 1 . Celnii du côté droit a perdu les extrémités qui s'articulent avec l'apophyse-zygomatique et le maxillaire. . . . •

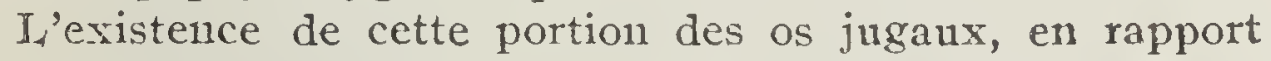
avec les apophyses-orbitaires et les arcades, nons permet de reconnaitre combien étaient grandes et profondes les cautés orbitaires des hommes de Spy.

L Ma Maxilatare Superieur.-Il n'en a été recueilli que des fragments. . .

Li Masillaire INFErieur.-La mâchoire inférieure est fort bien conservée chez le sujet No. 1. Il ne lui manque que tes extrémités des apophyses coronoïdes et les condyles. Si nous avions possédé ces derniers, la question si importante du prognathisme ou de l'orthognathisme facial de la race de Neéanderthal était résolue. . .

Nous n'avons pu déterminer l'angle mandibulaire; la région du gonion manquant sur cette mâchoire. Lees branches de la mâchoire inférieure du sujet No. 1 sont ext effet incomplètes.

Le bord postérieur ou parotidien, l'angle de la mâchoire ou gonion, les condyles avec leur col, l'extrénite des apophyses coronoïdes font défaut comme nous l'avons déjà dit. . .

Li: Bras.-Humérus. Les quatre humérus des deux aquelettes ont été retrouvés mais ils sont incomplets. Ils sont tous les quatre brisés an voisinage de la tête. Ceux du squelette No. 2 sont plus forts que ceux du No. 1. Ils sont trapus et pesants. Ils ont sensiblement la même hauteur que ceux des Européens modernes, moins longs que ceux des nègres d'Afrique en général.

BASsin.-Nous ne possédons du bassin que quelques fragments des os coxaux (ilion, pubis, ischion).... Ils sont trop incomplets pour les décrire.

Fearur. - Il n'a été retrouvé à Spy que le fémur droit entier du squelette No. 1 et la tête avec la moitié supérienre du fémur gauche du squelette No. 2. . . L Lincurvation à 
convexité antérienre du corps du fémur est tonte caracteristique. Elle n'existe, d notre connaissance, chez ancute race moderne sauf chez les négritos des Phillippines.

Page 615.-. . . Quand BI. 1s Frofesseur Firchow, lors d'un voyage récent qu'il fit à Liége eut exanniné cette piece, il nous déclara que nous arions surement, dans la recoustitition, relere un peu trop le temporal droit par rapport aux parietaux et à l'occinital. Il nous fit remarquer, en effet que dans la position que nous avious donnte à ce temporal son apophyse zygomatique ne pourrait se raccorder avec la branche correspondante de l'os jugal suivan: une ligne horizontale comma c'est le cas normal chez tous les crânes humains. Nous nous inclinons derant cette ờservation parfaitement fondée. Nous n'aurions pu changer la position donnée à cet os, sans risquer de compromettre l'état du reste du crâne, que l'énìnent professeur de l'université de Berlin a bien voulu nous déclarer parfaitemeat recoustitué. Nous arions d'alleurs déjà à l'époque de cette visite, fait exécuter la reproduction du crâne Fio. 1 dans cet état.

Page 704. - Fous n'osons pas être. . catégoriques au sulet de leur contemporanéizé. Fous arons, comme on a pu s'en convaincre plus haut, tous nos appaisements au sujet de l'áge géologique des hommes de Spy, sals vouicir pour cela affrmer que l'homme No. 1 a vécu en même temps que l'homme No. 2.

The following is the original French of the remarks of Professor Irugies Obermaier in L'dnthropologic for 1906 :-

La plupart des savants attribuent aux fragments humains de Féanderthal, pour des raisons anatomiques, l'antiquité des squelettcs de $S p y$ et parlent d'un âge Monstérien de ces derniers restes.

Pour ma part, je considère comme très problématique que ceux-ci appartenaient an Moustérien. L'intérieur de la grotte de Spy, qui a eté si mal fouillée par Rucquoy, contenait une conche Moustérienne sur laquelle se trouvait superposé un niveau moyen, qui rappelle d'une façou 
frappante le "Solutréen" de Menton, et qu'on doit placer au commencement de certe époque (comme Présolutréen). La terrasse au-devant de la grotte ne contenait aucune couche Moustérienne, mais à la base, les squelettes humains, a:-dessus desquels se trouvait la dite couche présolutréenne que recouvraient encore des vestiges d'un Palæolithique plus récent. L'étude des niveaux démontre que la vallée actnelle d'Orneau était déjà à peu près complètement formée, lorsque la couche inférieure de la terrasse qui renfermait les squelettes, se déposait. Ceux-ci étaient accompagnés d'une pointe monstérienne et d'une lame en grès lustré; plusieurs autres lames et trois pointes moustériennes gisaient encore non loin d'eux, comme WM. Fraipont et de Puydt ont bien voun me l'assurer à Liége. Comme on trouve encore une quantité de pointes à main au nireau moyen (ancien Solutréen) de la terrasse, il n'est pas impossible que nous soyons à Spy en présence de sépultures du commencement du Solutréen et non du Moustérien. Les sépultures de Menton et de Predmost en servent des parallèles frappants. (Les resies humains quaternaires dans l'Europe Centrale, par Hngues Obermaier. L'Anthropologie, Tome xvii. p. 55, et seq.)

\section{APPENDIX 111 .}

\section{Haeckel's Falsifications.}

Several years ago a serious exposure took place in Germany of the methods employed by Professor Einst Haeckel in his scientific work. In 1907 he had published in a pamphlet, Das Menschen=Problem, diagrams showing the embryos of man and of various types of apes, for comparison. Dr. Arnold Brass, of the Kepler-Bund, an association formed at Frankfort to reconcile science and religion, brought out at I.eipsic, in 1908, another pamphlet, Das Affen=Problem, in which he asserted that nany 
of the diagrams were inaccurate, and that others had been deliberately falsified. Haeckel's reply in the Miinchiner Allgcmeine Zeitmns of January, 1909, contained the following admission:-

"To put an end to this unsavoury dispute, I begin at once with the contrite confession that a small number (6 to 8 per cent.) of iny embryo diagrams are really forgeries in Dr. Brass's sense; those namely for which the observed material is so incomplete or insufficient as to compel us ... to fill in and reconstruct the missing links by hypothesis and comparative synthesis.... I should feel utterly condemned and annihilated by the artmission, were it not that hundreds of the best observers. and most reputable biologists lie under the same charge. The great majority of all morphological, anatomical, histological, aud embryological diagrams... are not true to nature, but are more or less cioctored, schematised, and reconstructed."

The zoologists of Germany were, upon this, compelled, to save theit owith honour, to throw Haeckel overboard, and they issued this statement in No. 8 of the Milnchner Allgemeine Zeitung :-

r'The undersigned professors, directors of laboratories, etc., herewith ceclare that they do not approve of the method of 'schematising' which Haeckel has in some instances made use of : at the same time, in the interests of science and professional freedorn, they condemn in the sharpest manner the warfare waged against Haeckel by Rrass and the members of the Kepler-Bund. They declare, noteorer, that the evolutionistic idea can suffer no detriment from some few inaccurately produced eurbryo-diagrans."

This was sigued by forty-six professors, representing twenty-five German and Austrian universities and scientific schools.

Anotkar declaration was issued by a number of scientific uren, friends of the Kepler-Bund, in the Augsburger Post-Zeitung of March 23rd, 1909, as follows :-

"We are in agreement with the Kepler-Bund when it demands that henceforth, as in the past, German scien- 
tific research shall rest on an uncompromising love of truth, and on the strictest personal sincerity.... Haeckel's want of conscientiousness in popularising scientific facts and philosophic speculations has been shown up by others besides Dr. Brass; we refer particularly to Wilh. His. . . To declare as unimportant such arbitrary nutilations of the diagrams of other workers as Haeckel has been convicted of by Rutimeyer, His, and Brass, manifests a laxity of opinion to which we cannot assent."

This was signed by thirty-six scientific men (twentyfive of them members of the Kepler-Bund), representing mineteen miversities, botanical lahoratories, etc., of Germany, Austria, and Switzerland.

These particulars are abridged from an article which appeared in the Bombay Examiner in November, 1909.

One of the accusations made by Dr. Brass against Haeckel was that he had taken drawings of other biologists and altered them-taking away fifteen or sixteen vertebre from one monkey-embryo and aitering the name, and adding tail-vertebra to another. He also added to a human embryo eleven vertebrae not in the original drawing.

A full account of the controversy will be found in a pamphlet, Im Interesse der Wisscnschaft, by Direktor IV. Teudt, published in 1909 by the Kepler-Bund at Godesberg, near Bonn.

The many references to the rorks of Haeckel which are found in such a book as Professor F. D. Cope's Prinary Factors of Organic livolution show the influence he must have exerted on some naturalists outside Crermany.

\section{A PPENDIX IV.}

On page 97 of this book reference is made to the very vague suggestions of various biologists as to the methorl of man's supposed evolution from an ancestral ape-like progenitor. When this was written I had not seen a paper read by Professor Carveth Read before the Anthro- 
pological Section at the meeting of the British Association at Birmingham in 1913.

Professor Read's theory is that all the prominent characters that distinguish man from the anthropoids are the result of some (or even one) of lis anthropoid ancestors having developed a liking for animal food, and having come out of the forest to seek it, thus increasing the supply of food. He catalogues the changes thus :-

1. Life on the ground.

2. The erect gait as the normal mode of progression, with all the changes of bone, joint, and muscle that make this possible.

3. Lengthening of legs and specialisation of feet.

4. Shortening of arms and development of hands.

5. Use of weapons.

6. Reduction of jaws and teeth.

7. Shortening of alimentary canal.

8. Association for hunting purposes.

9. Beginnings of speech.

10. Greater knowledge and intelligence.

11. Increase of capacity of skull.

12. Discovery of fire.

13. Loss of seasonal marriage.

14. Variability of man from race to race.

These points should be considered in connection with the suggestions of other writers given on pages 97 to 108 .

As regards No. 2, we have seen (p. 99) what Professor Keith says as to the magnitude of the structural transformation required by a change of posture, and that it could not have been brought about merely by the apes abandoning the forests in search of food.

Then we have seen (p. 104) that Dr. Wallace argues that man must have acquired his brain, as well as his erect posture, at a comparatively early period.

Then Dr. Read's theory says nothing as to man's loss of the hairy covering of his alleged ancestors.

Finally, it offers no solution whatever of any of the "unsolved problems" mentioned on pages 112 and 113 of this book. 


\section{APPENDIX V.}

\section{Is Nature Cruel?}

Dr. Wallace, in chapter xix. of The World of Life, discusses this question, replying to what he considers the erroneous and misleading statenents of Huxley in The Ninelecuth Century for February, 1888, as to the suffering cndured by the animal creation. He considers the existence of pain as having been developed in the animal world for a beneficent purpose, and as being limited to what is actually needed for the preservation of life. He says that all animals which breed rapidly, and which are necessarily kept down to their average numbers by those other animals that feed upon them, have little sensitiveness, and probably suffer nothing when being devoured. In this category he places "almost all aquatic animals up to fishes, all the vast hordes of insects, probably all mollusca and worms." In the higher animals, pain has been developed for the necessary purpose of safeguarding the body from often-recurring dangers, and it thus tends to preserve life, and where there is an absence of pain, as in the injuries caused in some cases by the X-rays, some of the investigators have suffered loss of life or limb.

As to the teeth and claws of certain animals, and the hooked beaks and prehensile talons of birds of prey, Dr. Wallace says that the idea that all these weapons exist for the purpose of shedding blood or giving pain is quite illusory; "their effect is wholly beneficent, even to the sufferer, inasmuch as they tend to the diminution of pain" (by making the death-pang shorter); "their actual purpose is always to prevent the escape of captured food." "In a state of nature the Carnivora hunt and kill to satisfy hunger, not for amusement, and all conclusions derived from the house-fed cat and nouse are fallacious." He comes to the conclusion that "the cruelty of nature is almost wholly inaginary."

Dr. Wallace sees the danger that his views may be used as an excuse for the dreadful practice of vivisection; 
this practice he denounces strongly as being brutalising and immoral.

Of course, in the words of Dr. Wallace, "the whole system of life-development" in the world is that of "the lower providing food for the higher in ever-expanding circles of organic existence." If we had had the ordering of the course of nature, what other plan could we have devised? If all animals had to die a natural death instead of being devoured by other animals, would not the world be full of corpses, and would not the suffering be increased a hundredfold? Dr. Wallace protests against the views of some writers as "a libel on nature, and on the Ruler of the Universe," and he contends that "whatever pain there is, only exists for the grand purpose of developing a race of spiritual beings who may thereafter live without physical pain . . . for all eternity" (The World of Life, p. 371).

It is quite clear that at some stage in the world's early history-at a time which has not been revealed to usSatan must have obtained some mysterious power over the brute creation, and this is shown by his having been able to use the serpent for the purpose of corrupting mankind. It may well be that from that time physical pain may have been introduced into the world. But then, of course, pain was one of the results of the Fall. Who can say, to-day, what proportion of the suffering now in the world is due to the vices and follies of man, continued throughout all the ages?

\section{ERRAT A .}

Page 6.-Liegé, should be Liége.

Page 160.-Model, should be modal.

Page 177.-Cryptograms, should be cryptogams. 


\section{GLOSSARY.}

THE following explanations of some words in this rolume may be found useful by readers who have not read many scientific books. It must be understood that some biological writers coin words of their own to explain their theories.

ABIOGENRSIS : Spontaneous generation; see p. 229.

ALBUMFN : A thick, viscous substance in animal bodies; it exists nearly pure in the white of an egg.

Albuminords: Substances allied to albumen.

ALVEOL $F$ : Pertaining to the sockets of teeth.

ANTHROPOID : Resembling man.

AropHysis : An offshoot or prominent part of a bone.

ATAVISM : The reproduction in a person or animal of the characteristics of some remote ancestor. But the Encyclopedia Britannica says : "Atavism is a n1isleading nante covering a number of very different phenomena" (Vol. xiii., p. 354).

BaCILli, BaCterIA : Minnte microscopic organisms.

Batrimism: See p. 222

BIOPHORES : See p. 246.

BRACHYCEPHALIC : Short-headed.

Branchial : Pertaining to the gills.

Calcarmous: Containing carbonate of lime.

Calvarium : The skull-cap.

CARnIVORA: Flesh-eating animals.

CrLL : A unit mass of living matter.

Cerrerrat : Pertaining to the brain.

Chromomeris, Chromosomis: See p. 246

COLON : 'The first of the large intestines.

Conchomdu: Having elevations or depressions like a bivalve shell.

CONDYLE: A rounded eminence of the joints of bones.

CONVERGENCE: See p. 242

CORONOID: Resembling a crow's beak; the coronoid process (or offshoot) of the lower jaw.

CORRELATION : See p. 244

CRINOIDS: Radiated animals reiated to the stal-fish.

Crossing: The mating together of animals of different varieties or species.

CUITURE : See p. 3.

CyTology: The science of the structure and functions of cells. 
CyToplasu: 'The outer portion of the protoplasm of the cell-unit.

DETERAINANTS: See p. 246.

Drivvial, : Produced by a flood.

Druvviun: Used by Continental writers for the Pleistocene epoch.

DOLICOCEPHALIC : Irong-headed.

EMrryo: Fimbryonic life is the life of an animal before birth.

ENDEMIC: Peculiar to a people or vation.

EPITHELIUM: The bloodless layer of the skin.

EUstachran 'IUb: : A slender pipe from a carity in the ea: to the back part of the mouth.

Fasciatron: Banding together.

FAUNA: 'The animals of a given area or epoch.

FrMur : The thigh-bone.

GANGLIA : Enlargements in the course of a nerve or tendon.

Gimidules: See p. 247.

GENERIC: Pertaining to a genus.

GeNeTIC: Pertaining to origin by birth.

HEP'ADACTYLOUS: Seven-fingered.

HERBIVORA : Herb-eating animals.

Hrixagonal, Having six sides.

HISTOLOGY treats of the minute structure of the tissues of plants, animals, etc.

Homologr: Correspondence in type of structure.

HoMOPLASY : See p. 188.

HORMONES: See p. 245.

HYBRID : Offspring of the mixture of two species.

HyBRIDISATION : See p. 225.

IDS, IDANTS : See p. 246.

IDIOPLASM: A term invented by Nägeli to explain his theory of heredity. (Encyclopadia Britannica, Vol. xix., p. 139.)

InORGANIC SUbSTANCES : Substances without life, including rocks, minerals, and chemical compounds.

IN SITU: In its original situation.

LARVA : An insect in the first stage of its metamorphosis after leaving the egg.

Mandrale: 'The lower jaw of rertebrates.

MANDIBULAR ANGLE: Angle of lower jaw.

Materialistic : Denying the existence of God, of the soul, or of spiritual beings.

Matrix : The cavity in which anything is formed, and which gives it shape.

MFTABOLISA: The continuous process by which living cells or tissues undergo chemical change. 
Metazo : See p. 253.

Mrcrocossi: A little world.

Mol,Luscs : Include cuttle-fish, limpets, snails, whelks, oysters, mussels, etc.

MoNocotyledonous: Plants with only one seed-lobe.

MORPHOLOGY : Treats of the forms of plants and animals.

NATURA NON FACIT SAL,TUM : Nature does not make leaps.

Notochord : The column forming the basis of the skeleton in an embryo.

OccipIral : Pertaining to the back of the skull.

OMNE VIVUM EX YIVO: Iiverything living comes from what is alive.

ONTOGENY: The history of the evolution of individual organisms.

ORBITAI, RIDGES: Ridges over the eyes.

ORTHOGLNESIS : See p. 219.

ORTHOGNATHISAr : The opposite of prognathism.

OSTEOLOGY: The section of anatomy which treats of the bones.

PaLAONTOLOGY : Treats of the ancient life of the earth; of fossils.

Pangenesis : See p. 247.

Parietal : Pertaining to the walls of the side of the skull.

PAROTID GLAND: The large salivary gland near the ear.

PATHOLOGICAL : Pertaining to diseases.

Pratagic: Pertaining to the deep sea.

PENTADACTYlous : Five-fingered.

Pharyngral, : Connected with the throat.

PHAKYNX: The throat.

PHYlogenY : See p. 76.

Pyysiology : Treats of the organs and their functions, in animals and plants.

PrrmfCord : Pertaining to the higher apes.

Polydacrylous : Many-fingered.

PREPOTINT: Of superior power; predominant.

Primates: The highest group of mammals, including raan.

Pronnthropos: Living form ancestral to man.

Prognathous, Prognathism: With projecting lower jaw.

Proliniration: The production of flowers from others by budding.

Pronograde: Not erect; with face downwards.

ProTOPLASir : A substance composing, wholly or in part. all living cells, tissues, or organisms of any kind; the physical and material basis of life.

Protozoa: See p. 253.

QUANTITATIVE: Relating to quantity.

RaDYCLE, RADICAL : The base of a chemical compound. 
RADIOLARIA: A class of marine protozoa.

RECTIGRADATIOAS : See p. 227.

Rones's : Gnawing animals-mice, rats, squirrels, etc.

SALTATORY : By leaps.

SEGREGATION : Setting apart from others.

Sfrum : The liquid portion of the blood.

Stxuar, Dinrorphism: 'This term applies when males and females of a species differ in form or colour.

Siliceous : Pertaining to flint or quartz.

Simian, SimioId : Ape-like.

SnmIDA: : The family name of the anthropoid apes.

SPICIFIC: Pertaining to a species.

STIMULI : 'Things that stimulate, or excite to action.

STRATIIIED: Deposited in layers in the earth.

SUPRA=ORBITAL: Above the orbit of the eye.

Suturis: Seams or joints uniting the bones of the skull.

SUPRARINal: Above the kidneys.

SYMPHYSIS : The union of bones by cartilage.

SYNCHRONISM: Concurrence in time.

Synchronous: Simultaneous.

SYNCHRONY: Concurrence in time.

TELEGONY : See p. 248.

THLEOLOGY : See p. 259.

Temporal bonk: Near the temple.

TORUS: A protuberance.

Troglonyris (cave-dwellers): A genus including the gorilla and chimpanzee.

UNGULATES: An order containing the hoofed quadrupers.

UNICELLULAR : Consisting of but one cell.

VINATION : The arrangement of veins in a leaf.

Vestigial ORgaxs are those which are supposed by erolutionists to show traces of descent from some other form of life.

VITALISII: See p. 222.

Zygonatic Boxt: The cheek bone. 


\section{INDEX.}

AUTHORS AND BOOKS OLOTED OR MANITONED.

Adloff: Das Gebiss des Henscizen und der Anturoponor= Aeby, 83 pircn, 82, 84

Agassiz, 299

American Naturalist, 104

Asaximander, 312

Anderson, Sir Robert: The Bible and IJom Criticism, 282

Anthropologie, $L, 48,49$

Archio fiir Anthropologie, 267

Astley, Rev. H. D. : Prehistoric Archaology, 98, 257, 276, 277

Avebury, Lord: Ants, Bees, and Il'asps, 1243, 205

Baer, R. E. von, 82, 84

Ball, Sir R. : The Story of the Hearens, 304

Bastian, H. C. : 257,278

Nature and Origin of Living Mattor: 233

Bates, H. W., 250

Bateson, W.: Materials for the Study of Evolution, 268

Mcndel's Principles of Heredity, 223

in Darwin and Hodern Science, 82, 203, 221, 224

Address at Melbourne, 257

Beecher, H. Ward, 148

Bell, Sir C. : I3ridgewater Treatise, The Hand, 186

Bergson, Henri : Creative Evolution, 63, 79, 226, 230, 318

Bibliothicea Sacra, 126

Branca, W. Der Stand unserer Fentmes inn fossilcu Mcuschen, 35, 37, 38, 43,44, 50, 52. 59, 54, 87, 88, 265

Brass, ג., 323

Brenil, Abbé, 275

Bullinger, E. W., 281

Bunüller, J.: Die Entwicklungstheorte und der Hensch, 67,83

Butler, Samuel : Evolution Old and New, 169

Cambridge Natural History, 30, 89, 233

Capron, F. Hugh : The Conflict of Tmith, 152

Companion Bible, 281

Contemporary Review, 202, 219, 225

Cope, E. D.: Primary Factors of Organic Tavinlion, 33, $44,49,79,80,87,90,94$; and see 104

The Origin of the Fittest, 198, 221

Dana, J. D., 299, 303

Dorwin and Nodern Science, 30, 42, 64, 82, 90, 191, 203, $218,221,224,258$ 
Darwin, Charles: The Descent of Man, 61, 69, 73, 91, 97, $101,181,182,185,243,267,307,316$

The Variation of Animals and Plants, 172, 247, 289, 316 The Origin of Species, $62,91,109,111,160,162,161$, $181,183,184,195,243,256,268,289,314$

Dawson, Sir J. W. : 301,302

The Story of the Earth and Man, 95

Origin of the World, 179, 299

Meeting Place of Geology and History, 132

De La Beche. Sir H. : Kesearches in Theoretical Geology, 201

Delage, Yves: L’Hérédité. 207

Dewar, D., and Finn, F.: The Making of Species, 55,151 , $174,175,176,202,205,209,244,245,248,251,252$, 295

Dods, Dr. Marcus : The Book of Genesis, 114

Drawbridge, Rev. C. L. : Common Objections to Cloristianity, 145

Driesch H., 222

Driver, Canon: The Book of Gencsis, 127, 144, 178, 236, 297

Drummond, Heury : Tile dscent of Man, 69, 76, 97

Duckworth, IV. H. L. : Prehistoric Man, 33, 43, 49, 98, 137,139

Eimer, G. H. J. : Organic Evolution. 220, 237.

Elbert, 38, 264

Encyclopcedia Britanica, 30, 33, 44, 57, 78, 50, 87, 89, 122, $133,137,140,142,166,167,175,177,151,197,198$, $199,221,230,233,241,244,245,246,248,253,256$, $275,292,298,306$

Everyman, 234

Fechner: Einige Ideen, etc. 119

Fiske, 148

Fleischmann, A. : Descendenziheorie, Dir, 195, 197, 290

Fraipont, J., and Tohest, M. : La Race Hunaine de Neande?tial. 42

L'Homme Contemporain dil Hanishout? dे Sisy, 45,56 Gadow, H., 191

Galton, F., 223

Gamble, F. W. : The Animal Tond. 80

Geddes, P., and Thomson, J. A. : Evolution, 81, 87, 90, $111,159,196,232,254$

Gladstone, IV. E. : The Impregnable Rock of Holy Scrip. ture, 296

Geikie, Sir A. : Encyclopadia Dritannica, 133, 137, 29 ? Globus, 48

Goodrich. F. S. : Evolut:on, 73, 102, 167, 169, 221, 232, 239, 243,267

Gray, J. M. : Bible Problens Explained, 281 
Gregory, IV. K. : Studics on the Evolution of libe Prinates, 41

Guenther, C.: Daring ard the Problems of Life, 114, 165,

Guyot, \$., 303 $166,169,231,23 \%, 291,318$

Hacckel, IE. : Die Welträtisel, 164

The Evolution of Man, 31, 92

The Last Link, 92

The History of Creation, 95,305

Das Menschenuproblem, 323

Ialsbury, Lord, at Victoria Institute, 293

Hanani, O.: Dic Abstammung des Henscincn, 35, 51, 54, $55,67,82,117,119$

Entwichlungslehte und Darwinismus, 187, 256, 290

Harmsworth Encyclopedia, 255, 256

Harris, J. A., 170

Henslow, G.: Present Day Rationalism Critichly Examined, 146,242

Heraclides, 313

Hertwig, Oskar, 258

Hertwig, R. : Lehrbuch der Zoologie, 34

Hipparchus, 304

Molden, L.: Hliman Osteology, 86, 269

How, J. 1.. in Encyclopadia Britannica, 137

Furst, C. H., 79

Inxley, T. H. : Essays, 129

Lectures and Lay Sermons, 306

On Some Fossil Remains of $\lambda$ Kan, 42

On the Rclation of Man to the Lower Atrimals, Gn

Mian's Place in Nature, 290, 293, 307

in Encyclopcedia Britannica, 181

Jones, Dr. E. Griffith : The Ascent through Christ, 147

Jones, F. Wond: Arboreal .Man, 99, 100, 107.

jones, Rev. J. D. : Notes on the Interrational Lessons, 145

Foith, Arthur: The Antiquity of $\operatorname{Man}, 1,25,27,29,41$, $49,57,58,74,87,99,101,113,139,137,138,26 !$, $270,275,277$

Flic Iuman Body, 60, 74, 75, 76, 82, 97, 99, 110, 108, 269,272

Izellogg, V. H. : Daruinisin To-day, 79, 102, 104, 171, 177, $179,206,210,220,236,238,240,247,252,317$

Kelvin, Lord, 280

Kent, A. F., 308

Kerner: Vatural History of Plants, 187

Koblbrugge, J. H. F.: Die morphologische dbstammung des Menschen, 33, 119, 243

Köliker: Upon the Darwinien Theory, 183

Kollnann, 266, 267

Kramberger, 14, 52, $26 \%$ 
Lamarck, Jean : Plilosoplive Zoologique, 235

Lankester, Sir Fi. R., 185, 244

Lehon: L'Homme fossil en Europe, $\mathbf{5 6}$

Lenormant, F. : Le's Origines de l'Histoire, 309

I,eucippus, 312

I,ewes, G. H., 257

Linnzus : Systema Naturce, 175

Lrock, R. H.: Recent Progress in the Study of l'ariation, etc., 171, 205, 209, 236

Lodge, Sir O., 202

Iyell, Sir C. : The Antiquity of Man, 111

Macalister, A. : Notes on the Fenland, 25

MacBride, E. W. : Zoology', 31, 68, 80, 86, 253, 288, 292

Discussion at Victoria Institute, 255, 258

McCabe, Joseph: Erolution from the Nebula to Man, 31, 180,280

The Principles of Evolution, 80, 203, 222, 227, 247, 280

MicDowall, Rev. Stewart: Seven Doubts of a Biologist, 149 Macfie, R. C. : Science, Matter, and Immortality, 256

Macnamara: Evidence from Craniology of the Position of Man in Nature, 55

Marett, R. R. : Anthropology, 32, 43, 54, 139

Martin, 38, 264

Masterman : Zoology, 178, 195

Maunder, E. WV., 303

Mendel, 9, 222

Mercer, Bishop J. Ii. : The Mystery of Life, 143

Metchnikoff, Elie : The Nature of Man, 33, 87, 128, 271

Minchin, in Encyclopadia Britannica, 253, 256

Mitchell, P. C., in Encyclopadia Britannica, 80, 87, 177, $221,230,233,241,244$

Mivart, St. George: Lessons from Nature, 91, 121, 188, 278,281

The Groundzerk of Scicnce, 162

Moir, J. R., 142

Morgan, '1. H. : Evolution and Adaptation, 102, 207

Theory of Evolution, 224

Mortillet: La Préhistoire, 52

Nägeli, C. von, 220

Natural Scicnce, 79

Nature, 25, 227, 278

Naville, H. E.: The Unity of Genesis, 293

Nuttall: Blood Immunity and Relationship, 64

Obermaier, H., 48, 264, 322

Orr, James: God's Image in Man, 145, 278

Sin as a Problcm of To-day, 282

Osborn, H. F.: Mcn of the Oid Stone Agc, 39, 41, 114, $139,264,265,270,276$

in Encyclopadia Britannica, 198, 199; wnd see 227 
Otto: Naturalism and Religion, 124, 188, 256, 290

Our Own Magazinc, 312

Parliamentary Paper, 307

Peloubet, F. N.: Select Notes on International Lessons for 1913,145

Pierson, A. T.: God's Living Oracles, 309

Many Infallible Proofs, 140, 303, 309

Plate, I.., 240

Popular Science Monthly, 56, 73, 140, 170, 219

Poulton, E. B. : Essays on Evolution, 251, 292, 317

Ptoleny, 304

Punnett : Mendelism, 225

Pycraft, W. P., 40, 262

Quatrefages, 55

Ramsay, F.P. : An Interprelation of Genesis, 282

Ramsay, Sir W. M. : Cities of St. Paul, 279

Ranke, J. : Der Mensch, 56, 83

Read, Cárveth, 325

Read, Sir C. H., in Encyclopea ia Britannica, 140, 142

Redpath, H. A.: Modern Criticism and Genesis, 144

Reid, Archdall : Evolution of Man, 124, 172, 317

Reinheimer, H. : Nutrition and Evolution, 205, 316

Reinke, J.: Der gegenzeärtige Stand der Abstammungslehre, 120

Principles of Biology, 258

Romanes, G. J.: Mental Evolution in Animals, 116

Wental Evolution in Man, 116

Thoughts on Religion, 116

Rotherham, J. B. : Emphasised Bible, 157

Ryle, Bishop Herbert: Early' Narratives of Genesis, 146

Schäfer, E. A., 229, 234, 280

Schwalbe, G. : $30,42,48,64,90$

Vorgeschichte des Menschen, 117

Science Progress, 40, 41, 142

Scientific Monthly, 142

Scott, D. H., 257

Scott, W. B.: The Theory of Evolution, 65, 103, 225, 280, 284,289

Selous, F. C. : African Nature Notes, 251

Sidgwick, A : in Darwin Centenary Volume, 77 in Encyclopadia Britannica, 78

Smith, Inlliott : Primitive Man, 262, 271

Spencer, Herbert: On the Inadequacy of Natural Selection, 208

Snyth, Rev. J. Paterson: The Bible for the Young, 145

Sulyth, W. Woods: Facts and Fallacies regarding the

Steinmann, 284 Bible, 31, 153

Stratz: Naturgeschichte des Menschen, 83, 85 
Sunday School Times, The, 279

Teudt, IV., 325

Thompson, D'Arcy W.: On Growth and Form, 185

'Thomson, J. Arthur : Darwinism and Human Life, 271

Heredity, $71,72,202,213,214,216,218,223,236,237$, $238,269,317$

The Wionder of Life, 70, 180

Times Literary Supplement, 116, 136, 186

'inton, Iieut.-Col.: The Truth of Christianily, 150

rylor, E. B. : Primitive Culture, 278

in Encyclopedia Britannica, 33

Variorum Bible, 282

Victoria Institute Transactions, 255, 258, 293

Virchow, R. : 48, 79, 140, 264, 269

Arclive juir pathologisclie Anatomie und Physiologie, 36

Zeitschrift fiir Ethnologie, 36, 50

Volz, 38, 264

Vries, H. de: The Mutation Theory, 207, 215, 216

Species and Varicties, 215

Wagner, M., 239

Wallace, Alfred Russel: Daruinism, 102, 104, 109, 114, $166,169,170,178,190,191,192,194,195,237,240$, $247,249,281,287$

The World of Life, 110, 128, 164, 167, 168, 177, 197, 225, $241,259,283,291,301$; see also 219,234

Wasmann, Rev. E. : Modern Biology and the Theory of Evolution, 34, 36, 43, 55, 66, 81, 120, 177, 243, 254, $263,288,291$

Watson, J. A. S. : Evolution, 32

Heredity, 213, 225

Weismann, August: The Ezolutionary Theory, 81, 96, 114, $166,202,209,214,215,231,254,319$

Wilser, 265

Wilson, Canon J. MI. Evolution and the Holy Scriptures, 143

Wilson, E. B. : The Cell in Development and Inheritance, 230

Wissler, Dr. Clark, in Scientific Monthly, 142

Wolff, G.: Beiträge aur Kritil des Darwinschen Lehre, 102

Der gegenwärtige Stand des Darwinishus, 207

Die Begriindung der Abstammungslehre, 67

Woodward, Smith : Early Man, 262, 264

Woollaston, T. V. : Coleoptera Allantidum, 169, 175

Wright, G. F. : Man and the Glacial Period, 55

Scientific Confirmations of Old Testament History, 303

The Origin and Antiquity of Man, 45, 126, 130, 131, 139

Zittel, K. A.: Grundzïge der Paläontologie, 291 


\section{ANIMAIS MINTIONED.}

African Animals, 252

Albatrosses, 240

Ammonites : 194, 228

Coiling, 220

Amcba, 181, 253, 25t, 255, 256

Amphibiatl, 243

Anaptomorphus, 80

Ancon Sheep, 179, 218

Antelope, 172

Antlers of Irish Stag, 220

Ants, 123, 177

Ape and Man, 123, 124

Archxopteryx, 197

Arctic Fox and Hare, 249

Arthropoda, 288

Bacilli, 167

Bacteria, 229

Bee, 124, 168, 211

Beetles, 176, 228

Birds : and Reptiles, 197

Colonrs of, 249

Eiggs, Colours, 206

of Desert Regions, 249

Bison, American, 168

Blind Fish and Amphibia, 208

Boar, 245

Bontebok, 252

Brachiopoda, 194

Butterflies, 240, 251

Camel, 168

Carp, 166

Cats, 245,249

Cod, 166

Cows, 171

Crabs, 179

Cretaceous Reptiles. 220

Crickets, 178

Crinoids, 220

Cuttle-fish, 211

Deer, Keenness of Scent. 208

Docking of Horses' 'Tails, 237

Dog, 123, 124
Dogs : 171,244

with Tails erect, 238

Dryopithecus, 88,89

Electric Organs of Fishes, 211

Elephants, 166

Elephant's Trunk, 197

Eocene Lemuroids, 90

Equidae, 196

Extinct Reptiles, 167

Eye of Proteus, 208

Fins of Fishes, 198, 290

Flat Fishes, 205

Flies, 229

Fossil Anthropoids, SS

Gill-slits of Fishes, 76, 79

Giraffe, 172, 252

Groats in St. Helena, 168

Golden Pheasant, 218

Gorilla, 60

Greenland Falcon, 219

Guinea Pigs, 218

Hares, 169

Herring, 166

Horns, 245

Horny Plates on Palate of

Animals, 237

Horse, Pedigree of, 196

Horses' feet, 206, 237

Insects, 176, 177, 291

Irish Elk, 208

Jackal-Dogs, 238

Kallima Butterfly, 205, 25?

Kangarco, Hind Foct, 237

Lemming, Norwegian, 168

I,emurs allered to be Man':

Ancestors, 90

lingula, 178, 194

Lizard, Burrowing, 243

IIacrourous Crustaceans, 289

Mrare of Lord MIorton, 248

Medusae, 289

Merino Sheep, 218

Merychippus, 196

Metazoa, 253, 255, 290 
Miacene Gibbon, 272

Mollusca, 288

Nautilus, 178

Neuters in Insects, 212

Ostrich, Foot, 237

Parrot, 123

Passenger Pigeon, 168

Paraguay : cattle; 179, $21 \mathrm{~s}$

Horses, 245

Parasites, 166, 253

Pea-fowl, black winged, 218

Pecten, 63

Pigeons, 171, 244

Pigs, 171

Polar Bear and Hare, 249

Porto Santo Rabbits, 179, 241

Proboscidea, Fossil, 197

Protist, 253

Protophyta, 253

Protoplasm, 253, 254

Protozoa, 181, 253, 254, 255, 256,290

Ptarmigan, 249

Quagga, 248

Rabbit, 166, 168, 179, 241
Rabbit's White 'Tail, 163, 250

Racehorses, 171

Rats, 168

River-snails, 194

Sheep, 171

Snakes, 236, 243, 251

Sphenodon, 62

Spider Monkey, the, 187

Squirrel, Flying, 243

Steinheim Snails, 193

Sturgeon, 166

'Tapirs, 190

Tarsius, 90

'lermites, 228

'litanothere Family, 227

Tortoise, 287

'Tortoises in Galapagros Islands, 191

'Trilobites, 194

'lufted 'lurkeys, 218

Vertebrata, 288

Whales and Walruses, 236, 237

TWings of Butterfly, 206

Zebra, 252

\section{THE HUMAN BODY.}

Appendix, the, $69,70,122$

Blood : and Skeleton, 68 of Man and Ape, 64

Tests, 64

- Sources of Iirror, 65

Brain : and Hairy Covering, $96,97,98$ of Man, 101, 121

Colon, 70, 122

Far of Man, 75

Fustachian Tuhe, 70.

Gouty Tendencies, 72

Hand of Man, 97, 121, 123

Hare-lip, 71

Human Eye, the, 61, 63,

122,211

r.eg and Foot, 83, 84, 86, 97
Muscles, the, $61,100,122$, 269

Nails of Man, 75

Notochord, 70

Pharyngeal Arches, 77

Pituitary Gland, 73

Polydactylism, 71

Psoas Muscle, 75

Speech, 121, 123

Supernumerary Мamme, 71

Suprarenal Glands, 73

'leeth, 83, 84

Thyroid Gland, 73, 122

'lip of the 'iongue, 208

Vestigial Organs, 69, 70, 122 Wrist of Man, 75 


\section{GEOLOGICAL PERIODS.}

Achenlean, 3, 4, 15, 137

Aurignacian, 7, 275

Azilian, 3

Cambrian System, No Fossils beneath, 212

Chellean, 3, 4, 137

Cretaceous, 200, 228

Devonian, 228

Glacial Epochs, 3, 130, 132, $133,134,135,136,167$

Iáter Palæolithic, 8

Magdalenian, 3, 137, 138 . 275

Middle Palæolithic, 9

Miocene, 3, 104, 109, 110, 113

Monsterian, 4, 9, 137
Neolithic, 3, 4, 5, 137

Oligocene, 3

Palaolithic, 3, 4, 137, 138

Pleistocene, 3, 4, 74, 75, $110,130,131,133,137$, 178,264

Pliocene, 3, 109, 110,137

Post-Glacial Eporch, 3

Pre-Mousterian, 16

Pre-Neolithic Man, 6

Secondary Period, 167

Solutrean, 3, 137, 275

Stone Age : 3

Artists' Riepresentations, 265

Tertiary, 138, 140, 167

Triassic, 99

\section{SKULLS AND SRELETONS.}

Abbevile Flints, 16, 143

Aberavon Skulls, 6

Acton, 9

Age of Spy Relics, 48, 59

Auriguac Skeletous, 7

Brazil Caves, 22

Brixham Cave, 8

Brünn Skull, 8

Buenos Aires, 22

Burmah Flints, 20

Bury St. Fdmunds Skull, is

Calaveras Skull, 143

California Skulls, 22

Castenedolo Skull, 19

Cheddar Cave Skeleton, S

Cissbury Skulls, 9

Clichy Skeleton, 17

Coldrum Skeletons, 5

Combe Capelle Skeleton, 9

Cornwall Skulls, 6

Crayford (Kent), 9

Cresswell Craggs Skull, \&

Cromagnon Skeletons, 7

Cromer Flints, 18

Dartford Skull, 15
Engis Skull, 6

Eoanthropus, 2, 39, 41, 262, 264

Foxhall (Suffolk) Jaw, 17

Galley Hill (Kent) Skeleton, 16

Gibraltar Skull, 11, 27, 52, 265

Grays (Essex), 9

Grenelle Remains, 17

Grimaldi Cares, 7

Grotte des Enfants, 7, 54

Halling Skeleton, 8

Hoxne Flints, 15

Ipswich Skeleton, 17

Java: (Pithecanthropus), 20

Jersey Skulls, 5

Kent's Cavern, 'Torquay, 6 , 8

Khartoum, Gebel Moya Cemetery, 20

Krapina (Croatia) Skeletons, 13, 51

Ita Chapelle-aux-Saints, 10 , 29,53 
I, F Ferrassie Skeletons,. 9, 53

Jansing (Kansas) Jaw, 22

La Quina Skeleton, 10, 53

Ife Moustier Skeleton, 10 , 28,50

Ife Puy (Lyons) Skull, 17

Malta Skull, 5

Manchester Ship Canal Skull, 6

Mauer (Heidelberg) Jaw, $18,53,59,265$

Mentone Skeletons, 7,54

Mickleton Skull, 6

Mildenhall (Suffolk), 9

Moulin Quignon Jaw, 16, 143

Muskham Skull, 5

Natchez (Mississippi) Bone, 21

Naulette Jawbone, 12, 50

Neanderthal: Man, 12, 14, $41-44,261,263,264$

Race, 11, 54-57, 58, 266

Remains, 14, 49-53

Skull, 28

New Britain Skull, 55

Newport (S. Wales) Skull, 6 Ochos Jaw, 13

Oldaway (E. Africa) Skeleton, 20
Olmo (Florence) Sku11, 17

Omaha Skeletons, 22

Paviland Cave Skeleton, 6

Piltdown (Lewes) Skul1, 23, 57,58

Pithecanthropus, 2, 20, 29$39,58,66,262,264,275$

Reconstructed Skulls, 26

River-bed Skulls, 5, 6, 7, 8

Schipka Jaw, 13, 50

Shippea Skull, 25

South Africa, Animal Remains, 20

Spy Skeletons, 12, 44-19, $263,264,266,320$

St. Brelade's Bay (Tersey) Teeth, 12, 52

Swanscombe (Kent) Implements, 15

Talgai (Queensland) Stull. 25

Trubach (Weimar) Teeth, $13,40,52$

Tilbury Skull, 5

Trenton (New Jersey) Skull, 21

Westminster, Admiralty Pruildings, 9

Wookey Hole Flint Implements, 8

\section{GENERAL INDEX.}

Abiogenesis, 229

Achatinella, 239

Acromegaly, 57

Adain's History, 155, 296

Adaptation, 240

"After lis Kind," 281, 282

Albumen, Dead, 232

Albuminoids, 231

Alternative Theories not

Satisfactory, 284

American Finds, 142
Analogy Deceitful, 181 Analogical Resemblances. 243

Ancestral Ape to Man, 96, 270

Ancient Higher Civilisation, 277

Animal Coloration, 248

Animal Organisation of HIa1, 73, 121, 269 
Animals, Means of Dispersal, 189, 191, 287

Arimals: Various Types, 288

Autedilavian Marriages, 144 Antedilavians, the, 127

Anthropoid Apes, 88

Antipathies of Animals, 240

Autiquity of Man, 125

American Finds of Fints, etc., 142

Ararat, 298

Arboreal Man, 99-101

Archebiosis, 235

Archegenesis, 235

Arctic Regions, 249

Arguments on Absence of Facts, 110, 257

Arthropoda, 288

Artificial Selection, 151, $161,171,173,282$

Artistic Productions in Caves, 276

Babylonia in Glacial Fpocin, 134

Bathmism, 221

Beagle, Voyage of, 185

Beavers, Bones polished by, 140

Beginning, in the, 301

Beginnings of Life Pushed Back, 292

Bibie its own llitness, 311

Hological Lnits, 245

Biometry, 170

Biophors, 246

Blood : and Skeleton, 68

Relationship of Animals, $66,67,258,268$

Bones of Man in Batte. fields, 111

British Association: Capetown, 159

Birmingham, 325

Dundee, 229, 280

Liverpool, 233

Melbourne, 108

Burial of Mousterian Man, 118
Burmah, Flints found, 139

Bushmen, 124

Cain's: Family, 156

Wife, 155

Cananites destroyed, 153

Caves of France, etc., 275

Cells, 230, 247

Central Asia, 134

Centres of Life, 181, 256, 289

Chamonix, Sinking of Glaciers, 136

Chance: 174,225

Repudiated by Darwin, 182

Changes involved in alleged Evolution of Man, 106

Chaos-Interval Theory, 299, 300

Chinese Foot-Binding, 237

Chromosomes, 246

Chromomeres, 246

Chronology : 125

of Bible, 125, 297, 299

Conclusions, 260

Congress : of Lisbon, 140 of Moscow, 140

Contradictory Evidence, 203

Convergence: in Animal Life, 242

may account for Neanderthal Characters, 266

Correlation, 244

Cosmic Evolution, 180

Created and Formed, 146, 158

Creation: and Erolution, $145,146,147$

as Aiteruative Theory, 286,290

Creation Narrative in Genesis, 193, 296, 300, 305

Creator: acknowledged by Darwin, 182

Argument for a, 259

Cretaceous reptiles, 124

Cromagnon Race, 275, 276

Cryptogams, 177

Calture, the, 3 
Darwin's Difficulties, 210

Darwin on a "Single Progenitor," 289

Darwin's Theory Unsatisfactory, 284

Daughters of Men, 153, 154 . 156

David's Geography, 312

Day's of Creation, 296

Death, a Difficulty of Science, 128

Deluge, 112, 297, 298, 309

Design and Purpose through all Nature, 164

Design through Erolutionary Methods, 14.4

Determinants, 246

Difficulties as to Natural Selection, 204

Diluvial Period, 118

Directivity, 146

Discontinuous Variations. 217

Dominant Species, 108

Dr. Wallace's Reply to: Spencer, 108

Schäfer, 234

Drawings in Carerns, 276

Dualism, 165

Earlier Race, 157

Earliest Living Beings, 290

Early Man, 275

Earth: Eistimates of Age of, 4

Earth's Beginnings, the, 301,302

East and West, 312

Easter Island, 277

Egypt, Flints found, 139

Egyptian Monuments, 178

Elimination of the Unfit, 173

Embryology, 75, 82, 268

Enoch, 127

Environment, 106, 241, 242, 249,255

Eocene: Man, 110

Sands at Clermont, 139

Eoliths, 138, 139, 141. 142,
Erect Attitude of Mian, 98

Eskinos, 124

Eve, Creation of, 152, 154, 156

Evening Primrose, 179, 216

Fividences of Evolution, 160

Ervil before the Fall, 309

Eivolution : and Adaptation, 149

and Environment, 106, 149,150

and Genesis, 281

and Man's Spiritual

Nature, 115

and Scripture, 150

and Students of Biology, 284

Defended by Dr. IV. B. Scott, 284

Doubts as to Theory, 234

of Body of Mall, 157

or Creation, $145,154,286$, 290

Pays a Tribute to the Bible, 283

Problem not Solved, 120

Theory of, $158,159,279$

within Limits, 193, 199, 282

within the Trpe, 288

Erolutionists of Various Classes, 280

Fixodus, 125

Experimental Evolution, Stations for, 170, 291

Experts, Evidence of, 260

Extinct Species, 177, 283

Facts needed, not Theories, 120

Fall of Man, 148, 309

Flint Implements, 5

Flint Jack, 142

Flints Chipped by Nature, 140,141

Filood, 112, 297, 298, 309

Fluctuating Variations, 217

Foot of Man, 97

Forgeries of Flints, 142 275 
Fossil: Forms, 195

Man, 2

Remains, 112, 292

Fourth Commandment, 300

Free-will of Man denied by Haeckel, 165

Fuegians, 124

Galapagos Islands, 188, 239

Gaps in Nature, 184

Gemmules, 246, 247

Genealogy : of Ezra, 126 of our Lord, 126

Genealogies, Patriarchal, 125

Geographical Distribution, 285,286

Geological : Age of Human Ren11ains, 264

Contemporaneity, 199, 292 Estimates of Time, 4 Succession, 193

Record Imperfect, 109

- Portions Fairly Coniplete, 111

German Writers, 117

Germ-Plasm 'Theory, 209, 213,246

Groups of Form1s, 290

Growth-Force, 221

Haeckel Criticised, 94, 96

Haeckel's : Evidence, 93 Falsifications, 323

Genealogy of Man, 92

Hairy : ancestors of Man, alleged, 102

Covering of Man, 96

Half-human Beings, 112

Harmony of Nature, 183

Heredity, 160

Homologies, 184

Homoplasy, 244

Hormones, 245

How could Modern Man be Evolved? 103

"Humanity" of Eoliths, 139, 141

Humanoid Stem, 112

Huxley's Attitude, 292

Huxley on Men of Science, 293
Hypothetical Ancestral Ape, 103

Idants, 246

Idioblasts, 246

Ids, 246

Ignorance, Argument from our, 256

Inmmensity of Space, 310

Immortal Elements in our Bodies, 128

Immortality of Protozoa, 254

Imperfection of Geological Record, 109

Improbable suppositions, 113

Infinity, 165

Inheritance of Acquired Characters, 209, 235, 285

Inorganic Evolution, 180

Inspiration, 149

Instinct and Intelligence, 124

Interbreeding, 103

Intermediate Forms between Man and Ape Lacking, 110, 111, 273

In the Beginning, God, 301

Ireland, 240

Islands, Separation from Continents, 107

Is Nature Cruel? 327

Isolation, 106, 239, 273

Jacques Inaudi, 271

Jews, the, 310

Keith, Prof., New Hypothesis, $29,58,74,261,269$

Lamarckism1, 235

Language, Man's Gift, 97

Law of: Ancestral Inheritance, 223

Recession towards Mediocrity, 103

von Baer, 76, 77, 268

Leaves of Plants, 206, 245

"Iemuria," 192

Like produces Like, 161

Life : born on our Planet, 231

Mystery of, 128

Light before the Sun, 302 
1,imitations, 173

Limits of Evolution, 180, 291

Iiteral-day Theary of Creation, 299

Iongevity : 130 of Patriarchs, 127, 128, 129

Iord Morton's Mare, 248

Lowest Organisms, 22.1

Machine Theory of Universe, 164

Mammals, Origin of, 91, 289

Mammoth, Remains of, 135

Man and the Anima!, 98, 121,160

Man's : Place of Origin, 105 Supposed Ancestry, 89

Materialistic Views of Haeckel, 164

Measurements of Plants and Animals, 170

Mendelian Experiments Criticised, 225

Mendelism, 222, 245

IIental: Development of Man, 105

Evolution in Man, 116

Metazoa, 253, 255

Micellee, 246

Millions of Individuals in Eivolution, 103

Mimicry, 250

Minerals, Huxley as to Evolution of, 183

Ministry of Munitions Committee, 307

Minneapolis, Falls of St. Anthony, 135

Miocene: Gibbon, 272, 273 Man, 87, 109, 110, 113, 272

Hiraculous Interferences needful, 152, 274

Misinterpretations of Scripture, 295, 299

Missing Einks : 1, 57, 101, 110

Failure of Theory, 261

Monism, 165

Monkeys have Small Families, 107
Multiple-character Evolution, 227

Multiple Origin : of Life, $256,259,289$ of Species, 193

Multiplication of Life, 160 , 165

1.Iuseum Zoologists, 252

Mutation Theory, the, 207, $215-219,271,284$

Irtilations not Inherited, 237

Natural Death, 129

Natural History Mruseum, 261

Natural Selection, 101, 103, $107,159,161,162,164$, $170,172,173,208$

Natural Species, 228, 238

Nature, a Purpose ranning throughout, 164

Neanderthal Spy Race (see Skulls)

Neolithic Peoples, 277

New Mexico, Exhumed Cities, 273

Niew Organs, Origin of, 247, 248

Niagara, 195

Noah : 127

to Abraham, $27 \mathfrak{3}$

Noah's Ark, 295

Obscure Phenomena, 203

Oceanic Islands, 286, 287

Ontogeny, 78

Order of Creation, the, 305

Organic: Beings, Relation of, 182

Iivolution, 180, 230, 237

Selection Principle, 227

world, Three Stages, 115

Origin of Life, the, 229

Origin of New Chatacters, 247

Crigin of World, 144

Orthogenesis, 219

Otia, Plain of, 140

Pacific Islands, Aucient

Stone Buildines, 278

Palreolithic Artists, 276,277 
Palæontological Evidence, 285

Palæontology knows no Ancestors of Man, 121

Panama, Isthmus of, 239

Pangenesis, 203, 247

Pangens, 246

Parallel-Formation, 243

Pears and Peaches, 171

Phyla in Zoology, 290

Phylogeny, 78

Pithecanthropus (see Skulls)

Plasomes, 246

Plastitudes, 246

Playing with Biology, 72

Pliocene Man, 109

Polyphyletic Theory, 258

Post-glacial Time, 131

Post-Tertiary 'Time, 131

Posture, Evolution Man's, 98, 99, 101

Pre-Adamite Man, 155, 156, 157, 301

Precipitin Tests, 65

Prehistoric Skulls and Skeletons, 261

Problems Unsolved, 74, 105, 112

Professors, Lord Halsbury on, 293

Pronograde Stage of Man, 100

Protective Coloration, 250, 252

Protoplasm, 181, 253, 254

Quantitative Biology, 170

Recapitulation Theory, 75, 267,285

Recognition Marks, 250, 252

Reconciling Theories, 155, 156,157

Rectigradations, 227

Reign of Law, 310

Relation of Organic Beings, 183

Religious Beliefs of Cromagnons, 276

Remote Islands, 213
Reversed Selection, 208

Reversion or Independent Variation? 269

Reversions may be Mendelian Phenomena, 269

Reversion Theory, 70

Rhine Glacier, 136

Rivers of America, 131, 132

Rudimentary Organs, 267

Sabbath, the, 307

St. Paul and Evolutionary Teaching, 148

Sais, Picture of, 120

Saitatory Evolution, 217

Sand, Grains of, 169

Sandwich Islands, 239, 278

Satan uses the Serpent, 309

Savage Races with 'Traces of Civilisation, 277, 278

Science and Scripture, 295, 301-313

Science knows nothing of Man's Origin, 121

Science Ripe for Darwin, 161

Scientific Facts, 312

Second Narrative of Creation, 158

Sedimentary Rocks, the, 304

Segregation, 223

Selective Value, 173

Senapé Stone, 143

Seth, 155, 156

Sexual Dimorphism, 206

Sexual Selection, 97, 101, 102

Simplicity of Darwin's Theory, 162

Sin, nature of, 149

Skin, Man's Bareness, 98

Skulls and Skeletons, Prehistoric, 261

Solar System, Evolution of, 180

Somme Valley, No Human Bones, 111

Species : and Varieties, 215

Creation of, 176 
Species: Difficulty of Definition, 175

How Many? 176

Master, 177

Provisional, 177

Specific Centres of Life, 289

Spencer Criticised by

Capron, 152

Spiritual Nature of Man, 114

Spontaneous Generation.

$143,180,184,229$

Squirrel, Flying, 243

Starry Host. the, 303

Sterility of Species, 211

Stone Images and Buildinga on Islands, 278

Struggle : for Fixistence, $160,162,167$

for wife, 102

Sub-species, 175

Sun, the, 206, 303

Sunday Labour Committee, 307,308

Supernatural Selection, 150 , 151

Survival of the Fittest, 173

Swarming Things, 178

Swiss : Glaciers, 136

I,ake Dwellings. 143

Synchrony of Geolonical Deposits, 201

Systematic Species, 228

Telegony, 248

Teleology, 259

Terrace Époch, 132

Tetraplasy, 228

'Theologians' Yiex's, 143

Theories and Facts, 117, 285

Theory after Failure of

Missing Ijinks, 269

Therapsida, 99

Transitional Forms, 210

Trees, 166
True to Type, 175

Two Books, the, 295

Uncertainties, 201

Unicellular Animals and Plants, 253

Uniformity of Natural Iaw, 302

Unit Characters, 245

Unity : of Godhead, 283, 342 of Mankind, 306

Tniverse, Haeckel's Theory。 165

Unknown Law of Life, 190

Untenable Theories, 299

Useless Organs, 211, 267

Usher's Chronology, 125, 126

Tility, 173

Variation : $160,169,171$

of Structure, How to Survive, 104

Limited, 174, 175

Medleys Confused, 201

Variations, 205, 206, 207, 272

Variety and Parent Species, 175,211

Vertebrates, 290

Vestiges of Useless Organs, 213,267

Virchow, R., as Anthropologist, 264

Vitalism, 222, 226

Tolcanic Origin of Islands, 287

IIallace and Haeckel, 163

Waterfalls of the World Post-Glacial, $13 \tilde{3}$

Water Newt, 100

Wasmann's 'Theory, 228, 288

"Without Form and Void," 302

Of many of the subjects in this Index, there is only slight mention in the Volume, but there is generally a reference to some book where further information will be found. 



